UNIVERSIDADE DE SÃO PAULO

FACULDADE DE FILOSOFIA CIÊNCIAS E LETRAS DE RIBEIRÃO PRETO

Departamento de Educação, Informação e Comunicação -DEDIC PROGRAMA DE PÓS-GRADUAÇÃO EM EDUCAÇÃO

ODAIR RIBEIRO DE CARVALHO FILHO

O Ensino de Geografia e o estudo do local:

o "Projeto Nós Propomos!" no estado de São Paulo/Brasil

Ribeirão Preto - SP 
ODAIR RIBEIRO DE CARVALHO FILHO

\section{O Ensino de Geografia e o estudo do local: o "Projeto Nós Propomos!" no estado de São Paulo/Brasil}

\section{Versão corrigida}

Dissertação apresentada ao programa de PósGraduação em Educação (PPGE) da Faculdade de Filosofia, Ciências e Letras de Ribeirão Preto (FFCLRP) da Universidade de São Paulo, para obtenção do título de Mestre em Ciências. Área: Educação.

Orientadora: Prof. ${ }^{\mathrm{a}}$ Dr. $^{\mathrm{a}}$ Andrea Coelho Lastória

Ribeirão Preto - SP 
Autorizo a reprodução e divulgação total ou parcial deste trabalho, por qualquer meio convencional ou eletrônico, para fins de estudo e pesquisa, desde que citada a fonte.

Carvalho Filho, Odair Ribeiro de

O Ensino de Geografia e o estudo do local: o "Projeto Nós Propomos!" no estado de São Paulo/Brasil. Ribeirão Preto, 2020.

187 p. : il. ; $30 \mathrm{~cm}$

Dissertação de Mestrado, apresentada à Faculdade de Filosofia, Ciências e Letras de Ribeirão Preto/USP. Área de concentração: Educação.

Orientadora: Lastória, Andrea Coelho.

1. Nós Propomos! 2. Educação geográfica. 3. Cidadania. 4. Práticas pedagógicas. 5. Estudo do local. 
Nome: Carvalho Filho, Odair Ribeiro de

Título: O Ensino de Geografia e o estudo do local: o "Projeto Nós Propomos!" no estado de São Paulo/Brasil

Dissertação apresentada à Faculdade de Filosofia, Ciências e Letras de Ribeirão Preto, Universidade de São Paulo, para obtenção do título de Mestre em Ciências. Área: Educação.

Aprovado em:

\section{BANCA EXAMINADORA}

Prof. ${ }^{a}$ Dr. a Andrea Coelho Lastória (orientadora)

Instituição: Faculdade de Filosofia, Ciências e Letras de Ribeirão Preto/FFCLRP Universidade de São Paulo/USP.

Julgamento:

Prof. Dr. Sergio Claudino Loureiro Nunes

Instituição: Instituto de Geografia e Ordenamento do Território -IGOT

Universidade de Lisboa - UL. Lisboa/ Portugal

Julgamento:

Prof. ${ }^{a}$ Dr. ${ }^{a}$ Silvia Aparecida de Sousa Fernandes

Instituição: Faculdade de Filosofia e Ciências

Universidade Estadual Paulista Júlio de Mesquita Filho/UNESP.

Julgamento: 
À minha mãe, Odete de Oliveira (in memoriam) com todo seu amor e gratidão por tudo que fez de mim ao longo de minha vida

Ao meu pai, Odair Ribeiro (in memoriam) pelo amor e carinho que dedicou ao longo da minha vida

À Ciência brasileira, aos pesquisadores e aos profissionais da saúde pela luta incansável contra a COVID-19 nossos guerreiros da vida. 


\section{AGRADECIMENTOS}

A Deus todo-poderoso por me permitir ter saúde e trilhar caminhos de prosperidade profissional e acadêmica de forma a ter disposição, oportunidade, vontade pessoal para desenvolver um percurso de grande importância, não somente em minha vida, na vida de muitas pessoas e, também, para a Ciência brasileira, com este trabalho no campo da Educação.

Aos meus finados queridos pais, Odete de Oliveira e Odair Ribeiro de Carvalho, por terem possibilitado uma Educação com amor, carinho e muita dedicação, além de terem proporcionado condições materiais e psicológicas para meu desenvolvimento humano e profissional. Eterna gratidão incondicional!

À Prof. ${ }^{\text {a Dr. }}$ a Andrea Coelho Lastória, pela honrosa oportunidade de desenvolver esta pesquisa, por ser incentivadora intelectual e emocional. Pela convivência profissional, amiga e respeitosa em todos os momentos. Uma pessoa admirável e que inspirou e estimulou meu amadurecimento acadêmico e profissional. Possivelmente uma das pessoas mais serenas e generosas que conheço.

Aos professores participantes da banca examinadora na apresentação da dissertação de mestrado, pelo aceite, pela disposição e contribuição para o desenvolvimento da investigação. Em especial, aos queridos professor Dr. Sérgio Claudino Loureiro Nunes e à professora Dr. ${ }^{\mathrm{a}}$ Silvia Aparecida de Sousa Fernandes, pelas contribuições em minha banca de qualificação. Agradeço os conselhos valiosos e pontuais como forma de crescimento intelectual na escrita feita para esta investigação. Ambos os pesquisadores voltados para um ensino de Geografia para a cidadania e que acreditam no bem-estar coletivo, no progresso e nos investimentos na Ciência como forma de combater as desigualdades sociais latentes no mundo globalizado.

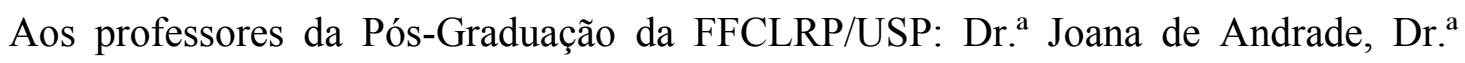
Vera Teresa Valdemarin, Dr. ${ }^{a}$ Filomena Elaine Assolini, Dr. Elmir Almeida e Dr. Geraldo Romanelli, que me constituem como professor pesquisador e contribuíram com a pesquisa.

Aos professores participantes desta investigação, pela disposição, disponibilidade e animação em contribuir com o trabalho desenvolvido, no sentido de colaborar para uma Educação cidadã.

À Faculdade de Filosofia, Ciências e Letras de Ribeirão Preto por possibilitar uma educação pública e de qualidade composta por dedicados professores e pesquisadores que nos proporcionam aprofundamento intelectual e profissional no campo da pesquisa em Educação. 
Aos amigos e companheiros de pós-graduação e pós-graduados, sempre disponíveis e incentivadores: Lucas Rosa, Carlas Moraes, Sandra Nunes, Caroline Vieira, Thais Azevedo, Sonara Souza, Adriana Cristina Godoy e José Faustino. Obrigado por todo apoio e parceria.

Ao Grupo de Estudos da Localidade - Grupo ELO - pelo incentivo constante e por possibilitar profusas ocasiões de aprendizagem da pesquisa e da docência; por ser um grupo que proporciona a vivência do que é o significado de coletivo, que acolhe, impulsiona e abre espaço para o desenvolvimento pessoal, profissional e intelectual. Além disso, pela partilha do conhecimento e da experiência acadêmica em eventos científicos e nos momentos de dúvidas e inquietudes.

Aos meus estimados amigos(as) que me acolheram e estimularam com conselhos produtivos para meus estudos e estabilidade psicológica, Maikon Guimaraes, Aledson de Britto, Paulo Dias, Dione Costa, Rodrigo Umbelino e Dário Rosa: o meu muito obrigado.

Às minhas caras amigas, Francislaine Carniel, Flávia Joize, Valquíria Aguiar Meneghesso e Daniela Nardy Gomes, pelos conselhos e orientações acadêmicas de sua experiência profissional, além de trazer ao nosso convívio tanto amor e bondade.

Ao meu querido amigo Diovani Alvarez, que me apoiou em muitos momentos da escrita com valiosos conselhos e caminhos possíveis para produzir um texto com rigor e qualidade. Um amigo que logo estará novamente entre nós.

Ao meu amigo Rodrigo Mateus Silva, pelos conselhos acadêmicos e por proporcionar condições profissionais para desenvolver a presente investigação. Obrigado pelo acolhimento incondicional e sincero.

A todos que me apoiaram e incentivaram, com amor, a seguir em frente com meus sonhos, sendo um deles por desenvolver uma investigação que colabore para uma Educação geográfica voltada para a cidadania em tempos obscuros e de rupturas democráticas tão severas. Em tempos de isolamento social e de pandemia da COVID-19, que nos afastaram fisicamente, mas não socialmente e emocionalmente, em tempos de temor pelo futuro e necessária crença na Ciência, como forma de superar este momento drástico e que coloca em xeque nossos sonhos e projeções para o futuro. Fica explicitado aqui minha crença inalienável na Ciência como promotora da justiça social. Juntos somos mais fortes e 'fique em casa' é nosso lema.

Eterna e sincera gratidão a todos vocês, meus queridos e queridas. Com todo afeto e carinho, o meu muito obrigado de coração. 
Quando o homem compreende a sua realidade, pode levantar hipóteses sobre o desafio dessa realidade, e procurar soluções. Assim, pode transformá-la e com seu trabalho pode criar um mundo: seu eu e suas circunstâncias [...] A Educação não é um processo de adaptação do indivíduo à sociedade. O homem deve transformar a realidade para ser mais. 


\section{RESUMO}

CARVAlHO FILHO, O. R. O Ensino de Geografia e o estudo do local: o Projeto Nós Propomos! no estado de São Paulo, Brasil. 2020. 187 f. Dissertação (Mestrado em Ciências) Programa de Pós-Graduação em Educação, Faculdade de Filosofia, Ciências e Letras de Ribeirão Preto, Universidade de São Paulo, Ribeirão Preto, 2020.

Neste trabalho partimos do pressuposto de que a educação geográfica deve desenvolver práticas propositivas que visem a reflexão sobre os problemas socioambientais, tanto em escala global quanto local, para possibilitar aos alunos o exercício de sua própria cidadania. Nesse sentido, a presente pesquisa objetiva levantar e caracterizar práticas pedagógicas de Geografia de cinco professores participantes em um projeto de ensino que desenvolveu ações entre os anos de 2017 e 2019, nos municípios paulistas de Marília, Ibitinga, Serrana e Mococa. As ações estão vinculadas a um projeto mais amplo, de abrangência iberoamericana, originado em Portugal, desde 2011/2012, denominado "Nós Propomos! Cidadania e inovação na educação geográfica". As práticas pedagógicas colocam o aluno como agente protagonista em sua realidade local, ideia que vai ao encontro de uma Educação que valoriza o estudo da localidade e do cotidiano na Geografia. O projeto promove o estudo do meio, entendido como uma estratégia de ensino interdisciplinar, realizada por meio do trabalho de campo, com o propósito de despertar o olhar crítico-reflexivo dos participantes sobre o espaço geográfico. As ações envolvem investigação e proposição de soluções para problemas locais aos alunos participantes, como agentes ativos da cidadania. A investigação, de cunho qualitativo, coletou dados por meio de revisão bibliográfica da temática sobre educação geográfica e sobre o próprio projeto. Além disso, entrevistou cinco professores participantes buscando responder a seguinte questão: como se configuram as práticas pedagógicas de Geografia vinculadas ao projeto, no estado de São Paulo? Os resultados explicitam formas particulares e próprias de desenvolvimento das práticas pedagógicas pelos professores, dentro de suas realidades locais e dos limites possibilitados pelas escolas. Consideramos que existem limites e avanços nas três categorias de análise da investigação, a saber: o projeto e a formação cidadã, a relevância da saída da sala de aula e as contribuições do projeto para os professores e para os alunos. Neste cenário, os professores promoveram práticas pedagógicas voltadas à autonomia e a solidariedade, com atitudes coletivas e cidadãs e com perspectivas para um ensino de Geografia, em direção a uma Educação crítica e propositiva.

Palavras-chave: Nós Propomos!. Educação geográfica. Cidadania. Práticas pedagógicas. Estudo do local. 


\begin{abstract}
CARVALHO FILHO, O. R. The Geography teaching and the location studying: the project We Propose! in the state of São Paulo, Brazil. 2020. 187 f. Dissertation (Masters) Education Department, Faculdade de Filosofia, Ciências e Letras de Ribeirão Preto, Universidade de São Paulo - FFCLRP/USP, Ribeirão Preto, 2020.

In this research we begin from the assumption that Geographic education must develop purposeful practices that aim at reflecting on socio-environmental problems, both on a global and local scale, to enable students to exercise their own citizenship. In these terms, the present research aims to raise and characterize pedagogical practices of five Geography teachers participating in a teaching project that developed actions between the years of 2017 to 2019 in the São Paulo municipalities of Marília, Ibitinga, Serrana and Mococa. The actions are linked to a broader project, of Ibero-American scope, originating in Portugal, since 2011/2012, called "We Propose! Citizenship and innovation in Geographic education". Pedagogical practices place the student as a protagonist agent in his local reality, an idea that takes account of Education that values the study of the locality and daily life in Geography. The project promotes the Milieu Analysis, regarded as an interdisciplinary teaching strategy, carried out through fieldwork, with the purpose of awakening the critical-reflective look of the participants on the geographical space. The actions involve examination and proposing solutions to local problems to participating students, as active citizenship agents. The investigation, of a qualitative tone, collected data through bibliographic review of topic on Geographic education and on the project itself. In conjunction with, he interviewed five participating teachers seeking to answer how are configured the pedagogical practices of Geography linked to the project in the state of São Paulo.The results detailing peculiar and specific forms of development of pedagogical practices by teachers, within their local realities and of the possible limits by schools. We consider that there are limits and advances in the three categories of research analysis, namely: the project and citizen training, the relevance of leaving the classroom and the project's contributions to teachers and students. In this scenario, teachers promote pedagogical practices aimed at autonomy and solidarity, with collective and citizen attitudes and with prospects for teaching Geography, towards a critical and propositive Education.
\end{abstract}

Keywords: We propose! Geographic education. Citizenship. Pedagogical practices. Study of the location 


\section{LISTA DE FIGURAS}

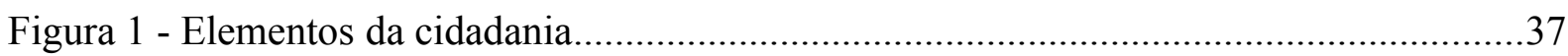

Figura 2 - Síntese da concepção de trabalho de campo..........................................................49

Figura 3 - Representação da $7^{\circ}$ etapa do "Projeto Nós Propomos! cidadania e inovação na educação geográfica", intitulada "Trabalho de campo e outras técnicas de pesquisa"...........51

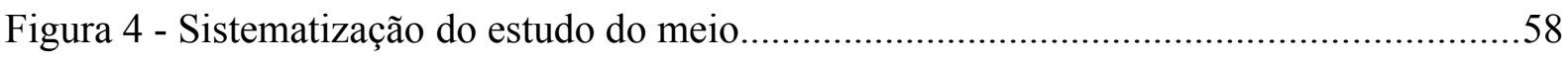

Figura 5 - Escolas portuguesas participantes no Projeto Nós Propomos! 2011/12-2017/18....75

Figura 6 - "Projeto Nós Propomos! cidadania e inovação na educação geográfica” 2019/2020.

Universidades da península Ibérica e instituições portuguesas...............................................76

Figura 7 - As parcerias do "Projeto Nós Propomos! cidadania e inovação na educação

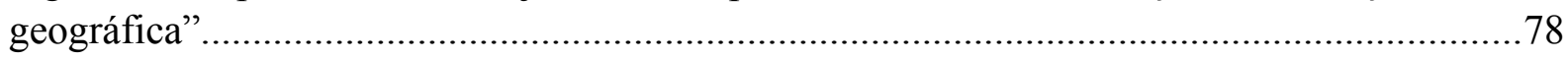

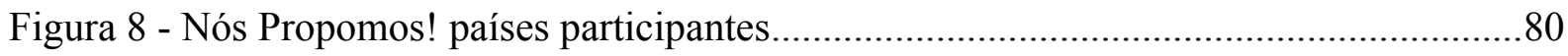

Figura 9 - Panorama das instituições brasileiras que colaboram com o projeto Nós Propomos!

Figura 10 - Tempo de atuação do projeto nas cidades brasileiras.

Figura 11 - O "Projeto Nós Propomos! cidadania e inovação na educação geográfica" na América Latina.

Figura 12 - Esquema de marcos legais de suporte ao "Projeto Nós Propomos! cidadania e inovação na educação geográfica" no estado do Tocantins/ Brasil..

Figura 13 - Esquema das contribuições teóricas para as ações do "Projeto Nós Propomos! cidadania e inovação na educação geográfica".

Figura 14 - Produções acadêmicas do GEOFORO de 2010 a 2018.

Figura 15 - Capa da obra publicada a partir das apresentações do I Congresso IberoAmericano Nós Propomos!.

Figura 16 - O "Projeto Nós Propomos! cidadania e inovação na educação geográfica" no estado de São Paulo.

Figura 17 - As parcerias do projeto Nós Propomos! realizadas no estado de São Paulo

Figura 18 - Apresentação das práticas pedagógicas referentes ao projeto Nós Propomos! na mesa redonda. 


\section{LISTA DE QUADROS}

Quadro 1 - Caracterização dos participantes - informações preliminares...............................70

Quadro 2 - Caracterização dos participantes - informações complementares.........................72

Quadro 3 - Categorias de análise quanto ao nível de atuação dos participantes.......................72

Quadro 4 - Síntese de algumas investigações sobre o Nós Propomos! defendidas e em

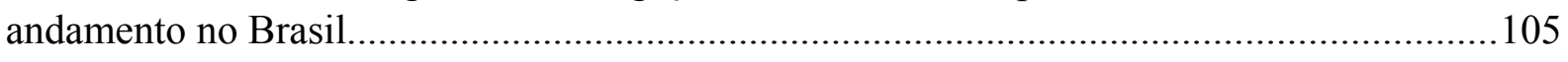

Quadro 5 - Relação de quantidade de alunos e turmas........................................................117

Quadro 6 - Sistematização das práticas pedagógicas desenvolvidas pelos professores

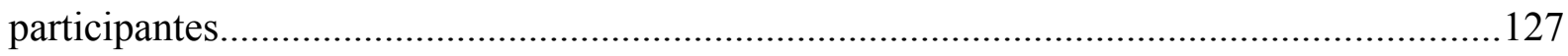

Quadro 7 - Síntese de elementos da cidadania na visão dos professores participantes..........131

Quadro 8 - Dados relativos à saída da sala de aula................................................................145

Quadro 9 - Resumo dos avanços e desafios do projeto Nós propomos! no estado de São Paulo. 158

Quadro 10 - Sistematização dos princípios do Projeto Nós Propomos! aplicados no estado de São Paulo 161 


\section{LISTA DE ABREVIATURAS E SIGLAS}

AGB

ANPOCS

BNCC

CCE

CEP

CF

CGE

CNPQ

COHAB

CONEP

CPEA

DEDIC

ELO

EM

ETEC

EU

FFCLRP

FUNVIC

GEAF

GEOFORO

IGOT

LAIFE

LDB

ONG

ONU

PCN

PEE

PROEX

PROGRAD

SME/RP
Associação dos Geográficos Brasileiros

Associação Nacional de Pós-Graduação e Pesquisa em Ciências Sociais

Base Nacional Comum Curricular

Comissão das Comunidades Europeias

Comitê de Ética em Pesquisa

Constituição Federal

Commission on geographical education

Conselho Nacional de Desenvolvimento Científico e Tecnológico

Companhia Metropolitana de Habitação de São Paulo

Comissão Nacional de Ética em Pesquisa

Centro de Pesquisas e Estudos Agrários e Ambientais

Departamento de Educação, Informação e Comunicação

Grupo de Estudo da Localidade

Ensino Médio

Centro de Escolas Técnicas Paulista

União Europeia

Faculdade de Filosofia, Ciências e Letras de Ribeirão Preto

Faculdade Universitária de Vida Cristã

Grupo de Pesquisa Ensino, Aprendizagem e Formação de professores

de Geografia

Foro Iberoamericano sobre educación, geografía y sociedad

Instituto de Geografia e Ordenamento do Território

Laboratório Interdisciplinar de Formação do Educador

Lei de Diretrizes e Bases

Organização Não Governamental

Organização das Nações Unidas

Parâmetros Curriculares Nacionais

Plano Estadual de Educação

Pró-Reitoria de Extensão

Pró-Reitoria de Graduação

Secretaria Municipal da Educação/Ribeirão Preto 
SP

TCLE

UFPA

UFRS

UFSC

UFSJ

UFT

UGI

UL

UNB

UNESCO

UNESP

UNICAMP

UNIOESTE

UPF

USP

UV
Estado de São Paulo

Termo de Consentimento Livre e Esclarecido

Universidade Federal do Pará

Universidade Federal do Rio Grande do Sul

Universidade Federal de Santa Catarina

Universidade Federal de São João Del Rei

Universidade Federal do Tocantins

União Geográfica Internacional

Universidade de Lisboa

Universidade de Brasília

Organização das Nações Unidas para a Educação, Ciência e Cultura

Universidade Estadual Paulista

Universidade Estadual de Campinas

Universidade Estadual do Oeste do Paraná

Universidade de Passo Fundo

Universidade de São Paulo

Universidade de Valência 


\section{SUMÁRIO}

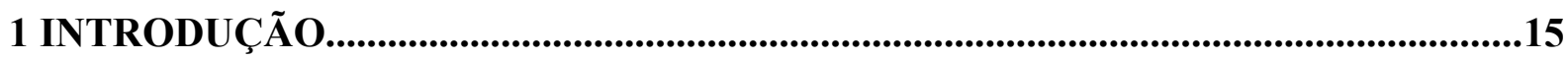

2 A EDUCAÇÃO GEOGRÁFICA E A CIDADANIA....................................................22

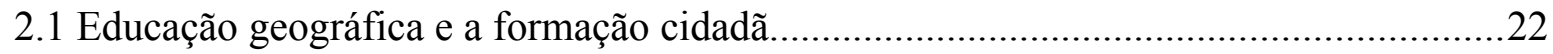

2.2 Considerações sobre a Cidadania na Educação..............................................................34

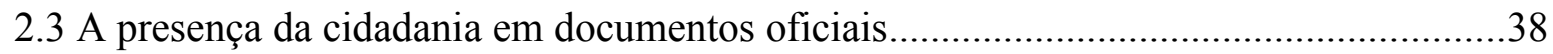

3 O TRABALHO DE CAMPO E O ESTUDO DO MEIO....................................................45

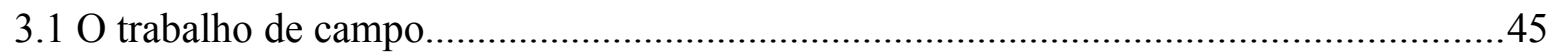

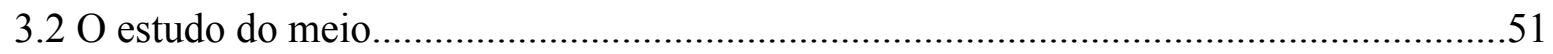

4 METODOLOGIA DE PESQUISA..................................................................................60

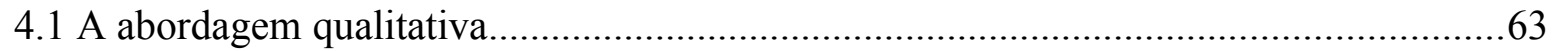

4.2 Os professores participantes e a coleta de dados no estado de São Paulo......................65

4.3 Caracterização dos professores participantes................................................................ 70

5 O PROJETO NÓS PROPOMOS! DESCRIÇÃO E ANÁLISE....................................73

5.1 O Projeto "Nós Propomos! cidadania e inovação na educação geográfica"...................73

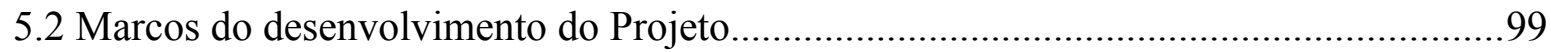

5.3 O "Projeto Nós Propomos! Cidadania e inovação na educação geográfica” em São Paulo

6 ANÁLISE DOS DADOS: AS PRÁTICAS PEDAGÓGICAS DOS PROFESSORES

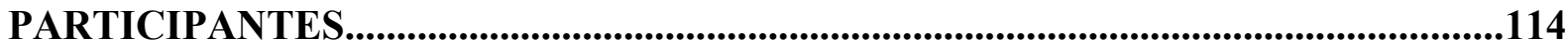

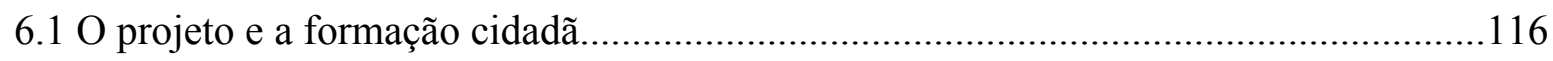

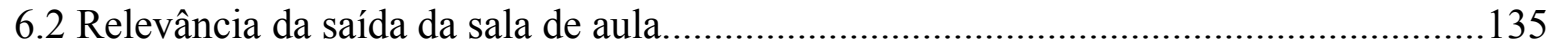

6.3 Contribuições do projeto para os professores e para os alunos....................................148

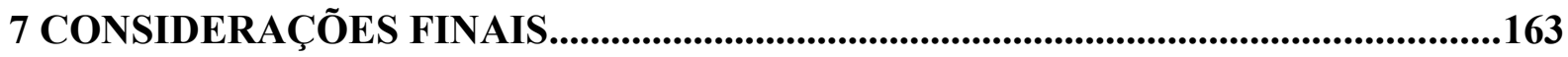

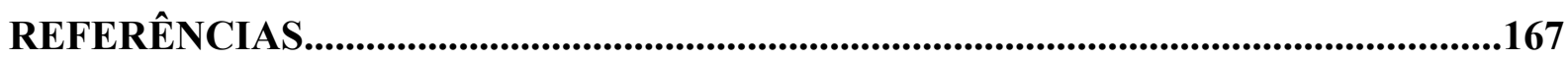

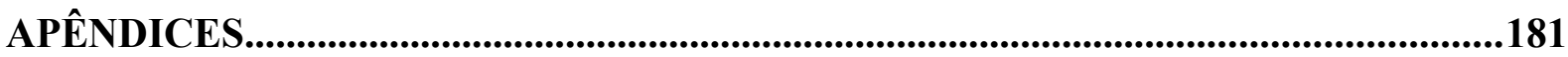

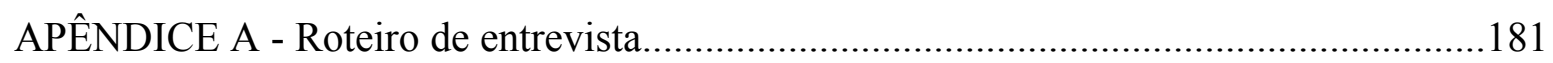

APÊNDICE B - Termo de Consentimento Livre e Esclarecido........................................182

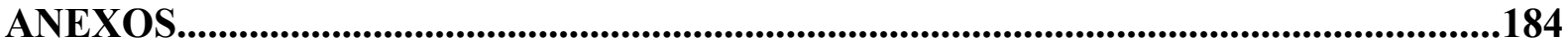

ANEXO A - Ofício do Comitê de Ética em Pesquisa (FFCLRP/USP) autorizando a coleta dos dados.

ANEXO B - Parecer do Comitê de Ética em Pesquisa (FFCLRP/USP) sobre o envio do relatório parcial. 


\section{INTRODUÇÃO}

"Há uma pedagogicidade indiscutível na materialidade do espaço" (FREIRE, 2014, p. 45).

A ideia de pesquisar a temática relacionada à formação cidadã começou, por nós, a ser levantada em nossa formação inicial, e continuou com o desenrolar do trabalho na área da Educação. Por meio de observações e questionamentos ao longo de nosso trajeto no magistério, tal temática passou a ser central em nossas vidas.

Durante nossa formação inicial em História, não tivemos uma sólida preparação para o desenvolvimento de práticas pedagógicas que visassem à Educação Cidadã, pois o foco estava nos conteúdos específicos da área da História. Nos eventos acadêmicos, ouvimos que a História tem como objetivo desenvolver o senso crítico no cidadão. Mas, algumas questões nos incomodavam: como desenvolver práticas pedagógicas para tornar o aluno um cidadão mais crítico? Quais ações o professor pode realizar no sentido de despertar a cidadania e a preocupação com o outro?

Com o ingresso na Rede Pública de ensino ${ }^{1}$, no ano de 2008, começamos a perceber sérias defasagens na formação dos estudantes quanto a terem um pensamento críticoreflexivo. A apatia e o desânimo em relação à Escola e ao ensino eram evidentes. O ensino de História parecia distante e sem função prática, e os professores pareciam cansados e desmotivados.

Sentimos a necessidade de entender melhor os processos de ensino-aprendizagem e começamos a cursar Licenciatura em Pedagogia. Percebemos a complexidade de ações que devem ser desenvolvidas para que os alunos consigam, de fato, aprender de forma válida e significativa. Começamos a entender melhor a complexidade da Educação, no sentido de ela ser um processo que pode "[...] gerar mudanças, promover melhorias e fazer parte integrante da consciência do educador" (DEPRESBITERIS, 1989, p. 45).

A partir desse momento, nossas práticas pedagógicas foram sendo alteradas, passamos a desenvolver ações que envolviam o sair da sala de aula e a utilização de outros espaços da escola e fora dela. A biblioteca, o pátio, o refeitório, o jardim, a quadra, o entorno da escola foram alguns dos locais utilizados para as aulas de História, para além dos “muros" da escola.

\footnotetext{
1 Nosso ingresso deu-se inicialmente como inspetor de alunos no município de Franca/SP. Posteriormente, trabalhamos como professor dos anos iniciais, na rede municipal de Orlândia, e, também, como professor de História, dos anos finais do ensino fundamental, nas redes municipais de Orlândia, Morro Agudo e, da rede privada, em Sales Oliveira/SP. Atualmente somos professores da rede pública municipal de Ribeirão Preto/SP e do Centro de Escolas Técnicas do Estado de São Paulo.
} 
Nosso entusiasmo em relação à Educação fez-nos começar a graduação em Geografia, ao mesmo tempo em que trabalhávamos como docente de História e realizávamos cursos de formação continuada de curta e longa duração ${ }^{2}$. Logo após o término dessa graduação, ingressamos, no ano de 2014, na rede municipal de Educação do município de Ribeirão Preto/ SP e, também, no Centro de Escolas Técnicas Paulista - ETEC, como professor de Geografia.

A nossa forma de ver e praticar ações pedagógicas foi sendo alterada aos poucos. Para nós, a sala de aula é apenas um dos espaços que podem ser usados pelo professor. A Escola possui muitos espaços para serem apropriados pelos docentes em suas práticas pedagógicas e, ao estudar o espaço geográfico, o professor não precisa e não deve ficar restrito à sala de aula.

Realizamos algumas novas práticas pedagógicas que saíam da sala de aula, de forma sistemática e alinhada aos conteúdos programáticos. Também, "arriscamos" e começamos a participar de alguns projetos temáticos com outros colegas professores. Algumas noções e conceitos foram problematizados como, por exemplo, o projeto "Águas e bacias hidrográficas", para ampliar a visão de mundo dos alunos, mas, principalmente, "testar" nossas estratégias didáticas.

Por meio de práticas e de projetos realizados no magistério, começamos a pensar não somente no global e nos fatos internacionais e nacionais, mas também nos locais. A localidade e a realidade local dos alunos ganhavam relevo e destaque nas nossas reflexões e práticas pedagógicas. Essas localidades tomam formas e tons diferentes, dependendo dos contextos e das especificidades locais e dos atores sociais envolvidos. Assim, outros questionamentos surgiram: como as práticas envolvendo a localidade podem contribuir para a formação cidadã? É possível pensar e praticar um ensino voltado para problemas da localidade? Qual a relevância e as potencialidades pedagógicas de se investigar na realidade local do aluno?

A formação cidadã estava sendo pensada e desenvolvida nessas nossas práticas ao sair da sala e apresentar o espaço geográfico, na sua "metamorfose", para os estudantes. As inquietações da nossa formação inicial em História estavam começando a ser desafiadas. Nossos alunos começaram a tomar consciência de uma educação geográfica mais comprometida com a cidadania, voltada para a localidade e para a importância do espaço público na constituição dos jovens (PIRES, 2016).

\footnotetext{
2 Durante nossa formação continuada, realizamos dois cursos de Especialização, um chamado "Ética, valores e saúde na Escola", promovido pela Universidade de São Paulo - USP, e o outro denominado "Metodologia de Ensino de História e Geografia", promovido pelo Centro Universitário "Barão de Mauá". Em ambos os cursos nossa preocupação foi buscar aprender práticas pedagógicas diferenciadas (que saíssem da sala de aula e desenvolvessem aprendizagens significativas para os alunos).
} 
No ano de 2014, ingressamos em um grupo de pesquisa, na Universidade de São Paulo. Denominado por Grupo de Estudos da Localidade - ELO ${ }^{3}$, o grupo desenvolve ações vinculadas ao Laboratório Interdisciplinar de Formação do Educador - LAIFE, na Faculdade de Filosofia, Ciências e Letras de Ribeirão Preto, na Universidade de São Paulo FFCLRP/USP.

Nesse momento, a temática da formação cidadã passou a ser refletida de uma forma mais organizada e contínua. Tivemos, então, a oportunidade de ampliar saberes e compartilhar experiências em um profícuo espaço de formação docente, com uma diversidade de pesquisadores atuantes na área educacional, e tomar contato com um projeto, de caráter internacional, com foco na educação geográfica para a cidadania.

Pudemos perceber, de forma mais concreta, que a Geografia pode ser um componente curricular mais significativo para os alunos a partir do trabalho envolvendo as saídas da sala de aula e a localidade dos alunos.

Com a nossa participação no grupo ELO e nosso trabalho no magistério, algumas questões surgiram envolvendo as saídas da sala de aula, a formação cidadã e o ensino de Geografia por meio do trabalho de campo: quais os desafios de realizar uma saída da sala de aula? Podemos promover a formação de um cidadão crítico por meio de projetos que envolvam o trabalho de campo? Em que medida o ensino de Geografia pode como contribuir para a promoção de práticas cidadãs?

Esses questionamentos foram sendo refletidos, por nós e pelos membros do grupo ELO, ao ponto de elaborarmos um material voltado para a formação continuada dos docentes com ênfase em saídas da sala de aula. Construímos, coletivamente, o "Almanaque de espaços não formais de ensino da região metropolitana de Ribeirão Preto/SP”. Tal publicação explicita treze espaços fora dos muros escolares e traz algumas propostas de saída da sala de aula, voltadas para a localidade ${ }^{4}$.

No Almanaque, “[...] partimos do entendimento que espaços não formais de ensino são todos e quaisquer espaços públicos ou privados, extra-muros escolares, que possibilitam o desenvolvimento de práticas educativas e a construção de saberes" (LASTÓRIA et al., 2018,

\footnotetext{
3 O referido grupo de investigação é reconhecido e certificado pela Universidade de São Paulo, no Brasil, desde o ano de 2006. Ele está inserido no diretório dos Grupos de Pesquisa do Brasil, mantido pelo Conselho Nacional de Desenvolvimento Científico e Tecnológico - CNPq. O Grupo funciona como uma comunidade de aprendizagem profissional da docência. Compartilha saberes da prática pedagógica, da área educacional e das áreas específicas de Geografia e de História. (CARVALHO FILHO et al., 2019).

$4 \quad \mathrm{O}$ referido almanaque está disponibilizado no seguinte site https://drive.google.com/file/d/1QSJLGkAr2rfZmL8-Gfey5ORiy7NaZNmY/view. Acesso em: 16 set. 2019.
} 
p. 7). Portanto, a nossa formação como docentes-pesquisadores entrelaça-se com as ações do referido grupo.

As leituras realizadas durante nossa convivência no grupo ELO auxiliaram-nos na compreensão tanto das dificuldades quanto das potencialidades de realizar saídas da sala de aula. Na reflexão sobre as potencialidades de estudar a importância da realidade local para os alunos e na capacidade de promover um ensino de Geografia voltado para a cidadania. Tais aspectos despertaram em nós o desejo de investigar melhor a temática. Nesse sentido, Bogdan e Biklen (1994, p. 85, grifo nosso) esclarecem que

Frequentemente, a própria bibliografia pessoal influencia, de forma decisiva, a orientação de um trabalho. Certos pormenores, ambientais ou pessoais tornam-se objectos aliciantes porque intervieram, de forma decisiva, na vida de um investigador [...] sem um toque de paixão pode não ter fôlego suficiente para manter o esforço necessário à conclusão do trabalho $[\ldots]$.

Isto posto, nossa preocupação está voltada para um ensino de Geografia que possa promover o envolvimento dos estudantes com os locais de vivência, o que permite uma maior participação cidadã. Desta forma, entendemos que é necessária uma investigação que aborde as saídas da sala de aula e um ensino de Geografia inovador por meio do estudo do local.

As práticas de trabalho de campo, presentes no estudo do meio, configuram-se, sob nossa ótica, como uma estratégia didática efetiva. Por meio delas é possível contribuir para aprendizagens significativas, nas quais o aluno e o docente, juntos, poderão pensar as formas do espaço e sua constante transformação, já que possibilitam trazer à tona múltiplas contribuições, tanto no campo teórico quanto no prático.

Partimos do pressuposto que o estudo do meio carrega uma perspectiva de promoção, não apenas do ensino de Geografia, mas de uma educação geográfica (CALLAI, 2011). Os alunos participam e exercem a sua cidadania. Eles não ficam "estáticos", e sim "em movimento", com tarefas que promovem resultados (LOPES; PONTUSCHKA, 2009).

Foi por meio do Grupo ELO que tomamos contato com um projeto internacional que promove a formação cidadã, utiliza as saídas das salas de aula e o estudo do meio como aportes da educação geográfica. O referido projeto, denominado Projeto de Ensino Iberoamericano "Nós Propomos!", foi idealizado pelo Professor Dr. Sérgio Claudino Loureiro Nunes, do Instituto de Geografia e Ordenamento do Território - IGOT, na Universidade de Lisboa- UL, em Portugal. Por meio do projeto, o aluno é valorizado como agente protagonista em sua realidade local. 
O projeto tem alcance atlântico ${ }^{5}$, sendo entendido como um projeto de ensinoaprendizagem ibero-americano. No Brasil, o projeto está sendo adaptado em diversas vertentes regionais, em cerca de vinte instituições federais. Em 2015, foi implantado no estado do Tocantins e no estado de Santa Catarina, e, em 2017, continuou ampliando-se (BAZOLLI et al., 2017a). Em 2017, as ações se iniciaram no município paulista de Marília, vinculado ao Centro de Pesquisas e Estudos Agrários e Ambientais - CPEA. Em 2018 nos municípios de Ibitinga, Mococa, Serrana e Ribeirão Preto ${ }^{6}$, vinculados ao grupo ELO, no Brasil.

O referencial teórico ressaltado nas ações do "Projeto Nós Propomos! cidadania e inovação na educação geográfica" envolve a educação geográfica para a cidadania e a ampliação do debate sobre o Direito à Cidade. Em algumas práticas já desenvolvidas pelo projeto, destacaram-se vários temas ligados à participação popular e a atuação ativa dos alunos no processo de levantamento de problemas e elaboração de propostas de ação voltadas ao coletivo.

O projeto, portanto, abarca o social quando coloca a participação cidadã do estudante em pauta e provoca reflexões nos estudantes e professores das escolas envolvidas. Nesse sentido, o "Projeto Nós Propomos! Cidadania e inovação na educação geográfica" promove práticas pedagógicas que envolvem o estudo do meio, possibilitando o estudo do local.

Isto posto, o objetivo central do presente trabalho é levantar e caracterizar as práticas pedagógicas dos professores participantes no "Projeto Nós Propomos! cidadania e inovação na educação geográfica" no estado de São Paulo, no Brasil. Diante do referido objetivo, delimitamos os objetivos específicos, a saber:

a) Descrever a sistemática do trabalho docente realizado;

b) Analisar, sob a ótica dos participantes, os impactos que tais práticas pedagógicas proporcionaram aos professores e aos alunos envolvidos;

c) Refletir sobre os desafios e os avanços do projeto tendo em vista o ensino de Geografia e a formação cidadã no Brasil.

\footnotetext{
5 Importante destacar que, em 2016, o projeto foi incorporado ao Global Understanding, o Ano Internacional do Entendimento Global (IYGU), que conecta ações locais e desafios à escala global e aborda as formas como vivemos num mundo cada vez mais globalizado. Informações disponíveis em http://www.globalunderstanding.info/pt/.

6 Desenvolvemos o projeto no município de Ribeirão Preto em uma escola pública, desde o ano de 2018, em conjunto com o grupo ELO, no entanto, essa ação não faz parte da presente investigação, pois somos os professores responsáveis por tal atividade.
} 
Consideramos que a pesquisa sobre as práticas pedagógicas desenvolvidas por meio do projeto "Nós Propomos!" pode revelar ações diferenciadas e não tradicionais de ensino. Esta pesquisa envolvendo o ensino de Geografia e o estudo do meio nas ações desenvolvidas em quatro localidades do Estado de São Paulo é inédita e possibilita compreender melhor as ações dos participantes, suas motivações e desafios para desenvolver práticas que buscam romper com a maioria das tradições escolares.

Diante do exposto, nossa questão central é: como se configuram as práticas pedagógicas dos professores participantes do projeto “Nós Propomos!", no estado de São Paulo, no Brasil?

Entendemos que realizar tal investigação possibilita-nos focar nos ideais democráticos, em que a Educação brasileira deve estar assentada. Possibilita, ainda, considerar reflexões sobre o Estado de direito e não sobre o Estado de exceção. Ler e entender o espaço contraditório brasileiro, assim como direitos, é uma forma significativa de resistência.

Além disso, pesquisas acadêmicas e debates que reforçam a importância das Ciências e da Educação na constituição do sujeito tornam-se necessários em um espaço democrático esvaziado por ações opressoras e de desmonte da Educação Pública.

Esta investigação envolve vários questionamentos surgidos ao longo da nossa trajetória, pessoal e profissional. Estabelece elos de ligação entre a necessidade de promover uma educação geográfica voltada para o exercício da cidadania, saídas da sala de aula de forma a desenvolver aprendizagem significativa aos alunos, e um projeto de ensino que pode despertar o protagonismo juvenil por meio do estudo do local, com a apropriação de noções e conceitos sobre o espaço vivido.

Esta introdução representa a primeira seção desta investigação. Nela apresentamos parte do nosso percurso profissional, o contexto de surgimento da pesquisa e nossas motivações pessoais. Para além disso, expusemos os objetivos e a questão central da investigação.

$\mathrm{Na}$ segunda seção, discutimos a importância que a educação geográfica tem na formação de cidadãos críticos na sociedade contemporânea, o que entendemos por cidadania e sua presença em alguns documentos internacionais e nacionais.

$\mathrm{Na}$ terceira seção, abordamos as diferenças conceituais que envolvem a saída da sala de aula, ou seja, refletimos sobre o trabalho de campo e o estudo do meio no ensino de Geografia. Usamos como principal referencial teórico as pesquisas da Prof. ${ }^{\text {a }}$ Dr. ${ }^{\text {a Nídia }}$ Pontuschka, no sentido de apresentar como o estudo do meio destaca a localidade dos estudantes e leva a um protagonismo juvenil, por meio da promoção do diálogo com o 
professor e com a comunidade escolar. Ainda, procuramos relacionar o estudo do meio (local), o trabalho de campo e o projeto Nós Propomos!

$\mathrm{Na}$ quarta seção, destacamos o referencial metodológico e explicitamos, portanto, a abordagem qualitativa das pesquisas educacionais. Salientamos a entrevista como forma de coleta de dados, a caracterização dos cinco professores participantes da investigação e seus contextos escolares nos municípios paulistas de Marilia, Ibitinga, Mococa e Serrana.

A quinta seção apresenta a descrição e análise do "Projeto Nós Propomos! cidadania e inovação na educação geográfica", ou seja, desde sua origem em Portugal, alguns marcos importantes para a concretização do projeto, seus objetivos gerais e a sistemática de trabalho educativo realizado. Em seguida, focamos nas ações desenvolvidas no estado de São Paulo, Brasil. Entendemos tais ações como sendo colaborativas, pois contou com a participação dos professores participantes. Analisamos em que medida o projeto contribui com as aprendizagens dos estudantes e dos professores para o desenvolvimento de uma educação geográfica mais voltada à formação cidadã.

$\mathrm{Na}$ sexta seção, analisamos as entrevistas com base em três categorias criadas na investigação. Percebemos elementos importantes para refletirmos as práticas inerentes ao projeto no âmbito nacional (Brasil) e regional (São Paulo). Por último, realizamos as considerações finais.

Em seguida, as referências, os apêndices e anexos são apresentados. O apêndice A (roteiro de Entrevista), o apêndice B (Termo de Consentimento Livre e Esclarecido), seguidos do anexo A (Documento de Aprovação no Comitê de Ética) e do anexo B (Parecer do Comitê de Ética sobre o envio do relatório parcial). 


\section{A EDUCAÇÃo GEOGRÁFICA E A CIDADANIA}

De alli el desafio de una educación para la democracia y la paz, afincada en el debate sobre las dificultades comunitarias y construir opciones colectivas fundamentadas en la opinión de los ciudadanos. Asi mismo, es importante convertir a la escuela en el escenario propicio para ejercitar la participación democrática. (SANTIAGO RIVERA; CLAUDINO, 2019, p. 277)

A presente dissertação segue um caminho de escrita que se inicia com uma discussão sobre o contexto de globalização em que vivemos, apontamentos sobre a educação geográfica e a formação cidadã. Nesse cenário, é necessário apresentar a pertinência da cidadania contextualizada em documentos oficiais da área educacional, que justificam as ações desenvolvidas no ensino de Geografia.

\subsection{Educação geográfica e a formação cidadã}

Na sociedade globalizada, vista a partir de suas contradições, e multifacetada em que vivemos no século XXI, a Escola apresenta múltiplas tarefas. Estas vão além das ações educativas. É preciso entender que a Escola é, também, uma instituição de produção dessas contradições.

A Geografia possui uma das funções de fazer com que o ser humano reconheça sua identidade e seu pertencimento no mundo globalizado. Este mundo apresenta fluidez constante, uma unicidade técnica, a convergência dos momentos e a unicidade do motor (SANTOS, 1994, p. 49). O primeiro é a capacidade de instalação da técnica em inúmeras localidades do globo, o segundo é a rapidez das comunicações e de serviços oferecidos e o terceiro é a direção centralizada à qual o mercado e o capital são atendidos pelas empresas. Isto posto, “A geografia deve trabalhar com uma noção de espaço que nele veja uma formaconteúdo e considere os sistemas técnicos como uma união entre tempo e matéria, entre estabilidade" (SANTOS, 2017, p. 189).

Nesse jogo de complexas relações, os impactos aos menos favorecidos são maiores e mais intensos, produzindo desigualdades e contradições. Esse fenômeno de globalização é homogêneo e tenta transformar tudo e todos, portanto, é necessário refletir sobre o binômio Sociedade/Natureza de modo crítico-reflexivo (SANTOS, 2017)

\footnotetext{
7 "Daí o desafio de uma Educação para a democracia e a paz, baseada no debate sobre dificuldades comunitárias e de criar opções coletivas baseadas na opinião dos cidadãos. Da mesma forma, é importante transformar a escola no cenário apropriado para exercer a participação democrática" (tradução nossa).
} 
Nesse cenário, a Geografia pode promover uma leitura de mundo de forma crítica e contextualizada das metamorfoses do espaço geográfico, como produto das ações antrópicas e das técnicas empregadas. Nesse espaço geográfico, lembramos do estudo Reclus (1905), no qual admite que não existe separação entre a sociedade e a natureza, na medida que o ser humano é natureza e toma consciência de si e, assim, este ser humano transforma a si próprio.

Desta forma, dentre as referidas ações desenvolvidas nesse espaço estão os problemas socioambientais e o que a humanidade enfrenta no cotidiano local e global. Neste sentido, como forma de contribuir com as funções da Geografia, Souto González e Claudino (2004, p. 10 , grifo dos autores) afirmam que

A Geografia deve colaborar na explicação de como se desenvolvem certos problemas sociais em territórios de diferente escala, tais como:

*nem todas as pessoas dispõem de um trabalho onde desenvolver as suas competências físicas e intelectuais,

*alguns países são explorados por outros através de relações comerciais injustas,

*no crescente processo de urbanização, há grupos de pessoas que vivem em situações de marginalização social junto a outras que dispõem de vastos recursos econômicos e materiais.

Diante desse contexto, no século XXI, a Educação tem como fundamento resistir ao processo "homogeneizante" com condutas pré-estabelecidas por certos grupos sociais, e, ainda, discutir os problemas socioambientais no ambiente escolar e nos diversos estratos da sociedade. De acordo com Sousa e Leite (2018, p. 12), a Educação

[...] incorpora a responsabilidade de promover a reflexão sobre o que é e não é adequado a um determinado local. Deste modo, um dos desafios que se impõe à Educação diz respeito à formação de capacidades críticas de lidar, de maneira propositiva, com rapidez com que estão estabelecidos novos padrões de conduta e com a formação um cidadão participativo.

Essa Educação deve ser pensada e praticada nas mais variadas formas, nos mais diferentes espaços, para desenvolver uma reflexão sobre as contradições da globalização e seus problemas socioambientais que atingem a humanidade. Deve preparar o aluno para ser ético, proativo e capaz de lidar com distintas leituras da realidade em prol de uma sociedade mais justa e igualitária para si e para o outro, no coletivo (SOUSA; LEITE, 2018).

As formas dessa globalização trazem problemas de ordem socioambiental que necessitam ser discutidos e percebidos pelos estudantes. Diante do exposto, é possível que 
y que por lo tanto nos afectan y atañen diretamente. Ante ello, es necesario abrir nuevas perspectivas de análisis y de actuación cidadana. Estas perspectivas pasan, ante todo, por abordar estas cuestiones desde um plano local-global [...], más acorde con las realidades de nuestro mundo. (GARCÍA PÉREZ; MORENO FERNANDEZ; RODRÍGUEZ MARIN, 2015, p. 34) ${ }^{8}$.

Essa concepção de Educação, para a atuação cidadã, permite que o ensino de Geografia na sociedade contemporânea seja ressignificado. Segundo Santiago Rivera e Claudino (2019, p. 278, tradução nossa) $)^{9}$, os temas e problemas sociais têm ligação com o contexto global em que estamos inseridos no novo milênio e essas situações "[...] colocar en el primer plano de la discusión a la politica como opción para ofrecer nuevas respuestas a las dificultades sociales más relacionadas con lo humano y lo social"

Diante disto, a problematização das questões socioambientais ganha expressão por meio do estudo do local e do global. A esse respeito, Lastória e Mello (2008, p. 31) explicam que

[...] pensar o lugar como espaço que está intimamente relacionado com o global - glocalidade - é compreender a existência de uma tensão dialética entre aquilo que se entende por mundo e como o próprio se mostra nos diversos lugares do globo. É crer o local como muito mais que uma aldeia fechada em si mesma, mas uma aldeia que lê o mundo de sua forma e devolve ao mundo a sua leitura apropriada, específica, é ainda, creditar valor planetário a uma dimensão que até então era menosprezada pelos geógrafos.

Notamos que o local ganha destaque na Geografia, na medida em que valoriza o cotidiano e as ações antrópicas locais, assim como as globais, para a transformação do espaço geográfico. Nesse sentido, Milton Santos apresenta pontos importantes sobre a construção do espaço geográfico em uma complexa relação de elementos sociais, econômicos e políticos na qual o global e o local relacionam-se de forma constante e contraditória. Para Santos (2017, p. $150)$,

Essas ações globais, desse modo tornadas mais eficazes, se caracterizam, também, por sua extrema fluidez, sua extrema substitutbilidade, uma sucessão possível de ser alucinante, graças aos eleitos conjugados da inteligência universal das empresas e bancos, da teleação e da competitividade. Cada lugar é teatro de combinações pouco duráveis, cujo

8 [...] a contemplação desse cenário nos permite ter uma visão mais completa e complexa das problemáticas que estão ocorrendo no ambiente e que, portanto, nos afetam diretamente. Diante disso, é necessário abrir novas perspectivas de análises e de atuação cidadã. Estas perspectivas passam, antes de tudo, por abordar estas questões desde um plano local-global [...], mas de acordo com as realidades do nosso mundo" (tradução nossa).

9 “[...] colocam em primeiro plano a discussão da política como opção para oferecer novas respostas para as dificuldades sociais mais relacionadas com o ser humano e o social” (tradução nossa) 
fator de mudança é esse dado global. Cada lugar é, assim, a cada instante, objeto de um processo de desvalorização e revalorização, onde as exigências de natureza global têm um papel fundamental.

Neste contexto, o espaço que o cidadão acredita ser seu de fato, no entanto, experimenta as faces hegemônicas da globalização, o que o deixa multifacetado (SANTOS, 2004). Portanto, concordamos com essa ideia de uma sociedade na qual as contradições estão presentes, por meio das desigualdades sociais e econômicas a nível global e local. O acesso aos serviços é diferenciado entre as pessoas, "[...] o indivíduo tornado consumidor" (SANTOS, 2004, p. 9).

Desta forma, em uma sociedade globalizada e multifacetada, a qual não dá o devido valor ao seu cidadão (ausência de serviços eficientes, precariedade de outros, falta de compromisso efetivo com o coletivo), o Estado arregimenta e manipula as pessoas. A cidadania torna-se mutilada e subalternizada (SANTOS, 2004).

As colocações de Santos (2004) nos ajudam a pensar o contexto espacial da globalização que dilacera a ideia do ser cidadão, além de apresentar problemas de várias ordens e dinâmicas. Então, a vida humana deve ser vivida por meio de uma

[...] geografização da cidadania que supõe que se levem em conta dois elementos a serem aplicados a todos os indivíduos: os direitos territoriais e os direitos culturais, entre os quais o direito do entorno. Cultura, educação, saúde, moradia, transportes, atendimento às necessidades elementares, lazer. Tais questões deveriam poder ser resolvidas ao nível estritamente local. (SANTOS, 2004, p. 150).

Notamos que o autor destaca o local como forma de (re) pensar a cidadania. A resolução de problemas de ordem local é posta como um dos fatores da possível formação cidadã, para além dos direitos e deveres que a coletividade é educada para saber e seguir.

Nesse sentido, o cenário político e educacional brasileiro atual exige engajamento de pesquisadores e professores comprometidos com a garantia de uma escola pública, gratuita e com qualidade. Desta forma, acreditamos que os impactos da referida globalização possam ser minimizados.

O retrocesso das políticas educacionais e a obstrução do desenvolvimento da Ciência no Brasil (LASTÓRIA; SANTOS; MELLO, 2018) são elementos importantes a serem considerados nas investigações educacionais que buscam ações para a formação cidadã. Nesse sentido, a Escola pode ser um espaço que visa a "[...] promover a igualdade social e o conhecimento diferenciado" (YOUNG, 2007, p. 1297). 
$\mathrm{Na}$ instituição escolar são formadas pessoas com conhecimentos que serão reproduzidos de formas variadas nos espaços públicos e privados. Essa Escola pode promover reflexões e práticas condizentes com a igualdade social e para isso “[...] It is essential to organize the school as a living space, where citizenship can be exercised at ll times and thus be learned, so that young people take ownership of school environment and enchance the identification ties with the school" (LASTÓRIA et al., 2015, p. 46) ${ }^{10}$. Assim, a Educação, por meio do ensino de Geografia e da Escola, pode contribuir, significativamente, para resistir, enfrentar e promover igualdade e justiça, em um contexto contraditório como o nosso.

Concordamos com o conceito de ensino de Cavalcanti (2002), que salienta ser o mesmo um processo que compõe a formação humana em sentido amplo, abrangendo todas as dimensões da Educação: intelectual, afetiva, social, moral, estética e física. Isto posto, é essa formação humana que confere corpo teórico e prático para a construção de uma visão de mundo para o aluno.

O ensino da Geografia Tradicional está, muitas vezes, restrito às paredes da sala de aula e às páginas dos livros didáticos. Um ensino presente, ainda, em muitas localidades do mundo e do Brasil e que há muito tem estado a serviço dos interesses das classes hegemônicas do Estado-Nação de forma conteudista (SOUTO GONZÁLEZ, CLAUDINO, 2004, p. 10).

Neste sentido, o Ensino tradicional apresenta muitos problemas para a Educação brasileira e pode comprometer a leitura de mundo de muitos estudantes e prejudicar a aprendizagem significativa deles. Para além disso, Queiroz (2019, p. 21) complementa que o “[...] ensino de Geografia na perspectiva tradicional tem dificuldades de provocar o envolvimento real dos alunos com os conteúdos, justamente pela distância que os mesmos são tratados em relação à vivência dos estudantes".

Lacoste chama nossa atenção e critica o ensino de Geografia tradicional, fragmentado e sem aplicação prática, repetitivo, fundamentado apenas na memorização, descritivo e mecânico. Esse ensino tradicional pode ocultar as causas sociais e políticas das desigualdades, muitas vezes a coberto de determinismos ambientais (LACOSTE, 1988). Dessa forma, notamos que algumas práticas pedagógicas ainda estão coniventes com uma cidadania multifacetada e homogeneizante.

Isto posto, podemos notar, por meio do estudo de Cavalcanti (2007), que ainda persiste uma forma de Ensino Tradicional e conteudista que coloca o aluno como agente passivo do saber por meio de "[...] mecanismos de alienação presentes na escola: verbalismo;

\footnotetext{
10 "É necessário organizar a Escola como um espaço de vida, onde a cidadania possa ser exercida em todos os momentos e, portanto, ser aprendida, para que os jovens melhorem seus laços de identificação com a Escola" (tradução nossa).
} 
enumeração de fatos geográficos; o ensino através da memorização; o ensino desvinculado da realidade do aluno" (CAVALCANTI, 2007, p. 124). Diante disto, devemos, como docentes, romper com esses mecanismos e promover a autorreflexão crítica do aluno sobre o espaço geográfico.

Assim, um dos desafios do ensino é "[...] aproximar conhecimento acumulado e realidade para que conhecimento não seja um artefato obsoleto e sim um instrumento para a compreensão e transformação da sociedade.” (MENDONÇA; CLAUDINO, 2016, p. 3). Desta forma, a análise da realidade deve fazer parte do aprendizado do estudante, como parte integrante de sua formação, tendo em vista uma formação cidadã.

Entendemos que, como docentes, é necessário rompermos com tal paradigma, propondo ações que visam à compreensão do espaço vivido (PONTUSCHKA; PAGANELLI; CACETE, 2009). Tais autores salientam, ainda, que a Associação dos Geógrafos Brasileiros AGB - teve papel fundamental, também, no processo de renovação do ensino de Geografia, articulando a universidade com a Educação Básica no sentido de promover um ensino significativo de ruptura com o tradicional.

Portanto, as práticas não tradicionais de Geografia surgem como nova perspectiva em relação ao aluno, à escola e ao espaço, pois o aluno passa a "ver" a Geografia, em vez de "ler" a Geografia, permitindo maior compreensão do espaço geográfico (CORDEIRO; OLIVEIRA, 2011). Seguindo este pensamento, concordamos com Souto González e Claudino (2004, p. 11) quando afirmam que

Não podemos ficar com uma concepção da Geografia como ciência do que se vê (a paisagem observável), mas dos factores que impedem a construção de um território público onde a cidadania é expressão dos direitos humanos. A Geografia deve colaborar na explicação de como se desenvolvem certos problemas sociais em territórios de diferentes escalas.

No caso, destacamos o ensino de Geografia como forma de desenvolver a leitura crítica do mundo, para que o aluno possa intervir em sua própria realidade de modo mais efetivo e com ferramentas conceituais para refletir e agir ativamente frente a diferentes problemas socioambientais.

Neste sentido, é necessário produzir novos significados para o ensino de Geografia para os alunos terem a oportunidade de se firmarem como cidadãos ligados aos problemas e destino de toda a sociedade e, assim, "[...] they therefore become participants in the struggle 
for collective and democratically defined rights and for a Society that grants equality and greater social justice" (LASTÓRIA et al., 2015, p. 52) ${ }^{11}$.

Para ampliar a discussão, Pontuschka, Paganelli e Cacete (2009) apontam a importância da Geografia, como ciência e disciplina escolar

[...] ciência humana pesquisa o espaço produzido pelas sociedades humanas, considerando-o como resultado do movimento de uma sociedade em suas contradições e nas relações estabelecidas entre os grupos sociais e a natureza em diversos tempos históricos. A Geografia, como disciplina escolar, oferece sua contribuição para que alunos e professores enriqueçam suas representações sociais e seu conhecimento sobre as múltiplas dimensões da realidade social, natural e histórica, entendendo melhor o mundo em seu processo ininterrupto de transformação, o momento atual da chamada mundialização da economia. (PONTUSCHKA, PAGANELLI; CACETE, 2009, p. 37).

Podemos notar, portanto, que ambas caminham juntas para o desenvolvimento do conhecimento científico dos alunos e a formação dos professores. Por meio do ensino de Geografia é possível compreender a dinâmica do espaço e suas complexas relações e representações. Para tanto, podemos buscar uma ruptura com o Ensino Tradicional por meio de práticas pedagógicas inovadoras.

Entre as "novas" práticas pedagógicas de Geografia, em uma Educação para além dos conteúdos listados nos programas curriculares, a ideia de trabalho com projetos de ensino ganha relevância como sendo uma forma de promover uma formação mais integral e que dê autonomia ao estudante.

John Dewey apresenta a importância do trabalho com projetos como forma de promover uma Educação em uma sociedade democrática. Esses projetos devem ser feitos por meio de mediação com os docentes e de forma a promover aprendizagens significativas aos envolvidos.

Lourenço Filho e Mendonça (2014) referem-se aos estudos de John Dewey (1976), que afirmam que a formulação de um projeto é uma operação intelectual bastante complexa e implica: a observação do território; o conhecimento produzido no passado; a avaliação das observações no presente; e o engajamento das experiências prévias dos estudantes.

O trabalho na escola e/ou em projetos deve ser cooperativo e partir das necessidades locais dos estudantes para ter significado na construção de sua perspectiva de vida escolar e pessoal. O resultado final desse trabalho complexo deve promover experiências educativas diversas (DEWEY, 1976). Nesse sentido, temos que

\footnotetext{
11 “[...] tornarem-se participantes na luta por direitos coletivos e direitos democraticamente definidos em uma sociedade que conceda igualdade e maior justiça social" (tradução nossa).
} 
[...] a necessidade da formação do indivíduo para a participação social, ou seja, para o desempenho de sua cidadania ativa, de uma atividade prática e colaborativa junto à sociedade; isso, naturalmente, pressupõe a necessidade do desenvolvimento da sua autonomia intelectual. A autonomia do educando é, portanto, considerada como o elemento que faz a ligação entre o mundo da teoria, presente nas atividades educativas e a vida prática do seu cotidiano, em que se situa como cidadão crítico, participativo, enfim, emancipado. [...] não podemos conceber a ideia de um cidadão que se educaria com o intuito de continuar inerte, passivo, dependente e dominado. (LOURENÇO FILHO; MENDONÇA, 2014, p. 200, grifo nosso).

Concordamos com os autores, ao afirmarem as contribuições de John Dewey para a Educação, no sentido de promover a cidadania ativa e o desenvolvimento de um cidadão crítico no cotidiano, capaz de ler e atuar no mundo de forma consciente e responsável.

Entendemos que a construção do conhecimento do estudante pode ser feita em uma “escola em miniatura" na qual "[...] seja capaz de desenvolver a cidadania, a responsabilidade e participação social de seus educandos, transportando a realidade aprendida e vivenciada na sala de aula para a vida cotidiana e concreta de seus alunos [...]” (LOURENÇO FILHO; MENDONÇA, 2014, p. 193).

O estudo de Zanata apresenta-nos as contribuições de Dewey para o ensino de Geografia ao afirmar que o filósofo considera "[...] ilimitado o alcance da imaginação na busca de apreensão das relações entre os fatos naturais e os eventos sociais e suas consequências" (ZANATA, 2013, p. 52).

Desta forma, podemos estabelecer ligação entre o ensino de Geografia e a ampliação do significado de uma experiência pessoal dos estudantes. Zanata (2013, p. 52) afirma que, segundo Dewey (1978), o estudo da Geografia contribuía para desenvolver "[...] a faculdade de perceber as relações espaciais, naturais, de um ato extraordinário".

Destacamos que a obra de Dewey defende a ideia de um aluno como sujeito do processo de ensino-aprendizagem e dotado de sua individualidade, dentro de seus interesses e necessidades (ZANATA, 2013). Nesse cenário, a Escola não deve estar isolada da sociedade, e sim conectada com o coletivo e seus problemas locais. Deve ser uma Escola comprometida a pensar nas experiências do estudante como forma de promover o ensino como um processo com determinada finalidade e necessário para a vida dos estudantes ${ }^{12}$.

\footnotetext{
12 Neste trabalho, fazemos referência à obra de John Dewey e aos autores que o estudam apenas para apresentarmos a concepção de alunos que possuímos e, também, para destacar as contribuições do referido autor para o campo da Geografia escolar. Não é nossa pretensão, nesta investigação, discutir outros aspectos da obra de Dewey em relação a suas concepções de sujeito e sociedade tendo em vista o projeto Nós Propomos!.
} 
A autonomia desse estudante pode ser construída pelos professores e pelas práticas pedagógicas voltadas aos "[...] saberes do cotidiano, sentimentos que envolvem o trabalho pedagógico na escola, criticidade, a valorização do saber do sujeito educando no sentido de ouvir e perceber a sua leitura de mundo" (FREIRE, 2014, p. 79).

Essa autonomia para a tomada de decisões e entendimento da complexidade das relações sociais pode ser feita por meio do local e das vivências da escola, na escola e para a escola. Freire (2014, p. 32) lembra-nos alguns questionamentos acerca do ensino:

Por que não aproveitar a experiência que tem os alunos de viver em áreas da cidade descuidadas pelo poder público para discutir, por exemplo, a poluição dos riachos e dos córregos e os baixos níveis de bem-estar das populações, os lixões no coração dos bairros ricos e mesmo puramente remediados dos centros urbanos?

Podemos notar uma ampla preocupação com uma Educação crítica, que tem o local e o cotidiano como fundamento de suas ações para o desenvolvimento da autonomia do estudante. O problema está no centro do ensino e ele pode ser debatido de forma significativa para os alunos ${ }^{13}$.

Os estudos de Dewey (1976) e Freire (2014) levam-nos a entender como uma Escola que trabalha com projetos, de forma dialógica e crítica, na busca por um ensino com foco na geração do conhecimento entre professores e estudantes, pode trazer aprendizagens significativas aos alunos imersos no mundo globalizado contemporâneo.

Destacamos que existem afastamentos teóricos entre os referidos autores ${ }^{14}$, principalmente no que se refere ao ato pedagógico como diálogo, pois Dewey caminha no sentido de entender o ser como psicopedagógico, enquanto Freire o entende como políticopedagógico (MUDARO, 2013).

Ambos os autores rompem com uma Educação tradicional, cada um em seu tempo e contexto histórico, ao propor um olhar diferente para o educando (MURARO, 2013), (ZANATA, 2103), com base em sua integração com a sociedade e como agente ativo do conhecimento. Desta forma, ambos entendem que a Educação é

\footnotetext{
${ }_{13}$ Destacamos que o termo aluno é usado por nós nesta investigação para fins didáticos, no entanto concebemos o sujeito aprendente como estudante, assim como coloca Paulo Freire em sua obra. Estudante no sentido de participante do conhecimento e não somente como agente passivo do saber.

${ }_{14}$ Temos a convicção que as linhas teóricas dos referidos autores são diferentes em muitos aspectos, no entanto procuramos relacioná-los no que se refere ao entendimento que apresentam sobre Educação, democracia e ao educando.
} 
[...] transformação da própria vida, entendida por Dewey como ampliação das possibilidades de vida pela aquisição da capacidade de pensar reflexivamente os problemas e, por Freire, como desenvolvimento da consciência crítica que problematiza a própria realidade como condição de superação das condições históricas opressoras. (MURARO, 2013, p. 827, grifo nosso).

A Educação é a marca da própria vida humana e pode ser capaz de transformar o indivíduo e o coletivo pelo ato da reflexão e da consciência. Neste sentido, podemos admitir que o pensamento reflexivo é, para Dewey, condição de possibilidade da vida democrática, por meio da constante interação entre o sujeito e a sociedade. Em Freire percebemos uma relação de democracia ao exame dos problemas no cotidiano (MURARO, 2013).

Destacamos, no entanto, que Freire avança nesse pensamento reflexivo ao relacioná-lo com a possibilidade do desenvolvimento da autonomia do educando. Essa autonomia pode se construir e se desenvolver no ato em si da Educação problematizadora e dialógica constante, para o protagonismo do educando em sociedade (FREIRE, 2014).

Com base nas reflexões de Educação e sujeito que apresentamos, admitimos que o contexto em que vivemos é contraditório e complexo. Assim, cria-se uma sociedade multifacetada, ao mesmo tempo em que as forças da globalização intensificam as interrelações no espaço geográfico, por meio de um ensino de Geografia tradicional e descritivo. Por outro lado, existem forças que enfrentam esse contexto promovendo uma Educação voltada para a autonomia, e para a libertação das amarras da opressão (FREIRE, 2004).

Ainda nesta conjectura contraditória em que a Educação está inserida, presenciamos a existência de um ensino de Geografia concebido como uma matéria ou disciplina escolar pouco significativa para os estudantes brasileiros. Em outra medida, defendemos um ensino de Geografia que

[...] procura desestabilizar as formas de entender o mundo, defendendo outros direcionamentos para as análises geográficas geradas a partir das insatisfações pelas explicações sobre as desigualdades sociais e as contradições espaciais em decorrência das relações capitalistas' (MARÇAL, 2012, p. 39).

Entendemos, portanto, que um ensino de Geografia nesses moldes só é possível com ações conjuntas de professores, alunos, gestores e comunidade escolar. Todos trabalhando juntos em prol de melhorias e combate ao processo de sucateamento educacional. Para além disso, é necessário o desenvolvimento de políticas públicas de ensino que promovam a educação geográfica para a cidadania. 
Para desenvolver um ensino de Geografia crítico e engajado, o docente precisa estabelecer uma forma dialógica de pensar e praticar o ensino de Geografia. Esse professor de Geografia tem sempre que "[...] buscar a totalidade do espaço enquanto dinâmica e processo, relacionando seus elementos enquanto método, não perdendo de vista o conjunto e o contexto" (SERPA, 2006, p. 11). A Escola, a Educação e o ensino devem estar integrados com as relações sociais e, de forma simultânea, o local ao global. Essa integração pode ser constante e dialógica com as realidades dadas pelos alunos e pela comunidade escolar.

Podemos, na condição de pesquisadores e professores, de forma coletiva e ampla, promover um ensino de Geografia que permita, aos alunos, desenvolver vários eixos de conhecimentos, dentre os quais diferenciamos dois deles. Um primeiro, sendo os conteúdos atitudinais, procedimentais e conceituais ${ }^{15}$, e um segundo, sendo habilidades e competências ${ }^{16}$. Desta forma, apontamos que a educação geográfica permite

[...] que os alunos analisem criticamente o mundo em que vivem. Uma perspectiva internacional é um produto essencial no estudo da geografia, uma vez que a compreensão requer conhecimento significativo. O conhecimento significativo é necessário para tomar decisões importantes sobre as condições humanas e ambientais de curto e longo prazos na Terra.

(GRAVES; STOLTMAN, 2015, s/n, grifo nosso apud BROOKS; QIAN; SALINAS-SILVA, 2017, p. 8).

A educação geográfica proporciona o desenvolvimento da consciência de tomada de decisões, cobradas de forma constante neste contexto de globalização. Essas decisões podem ser tomadas na esfera local para modificar o espaço vivido dos alunos e proporcionar a eles uma melhor qualidade de vida. Para complementar a ideia exposta, Castellar (2005, p. 220) esclarece que

Pensar pedagogicamente os saberes geográficos numa perspectiva metodológica e significativa para os alunos implica desenvolver ações que reestruturem os conteúdos, inovem os procedimentos e estabeleçam com clareza os objetivos. Desse modo, considera-se que a prática educativa da construção de conceitos, atitudes procedimentos, socialmente, no grupo familiar ou na escola, se faz considerando o conhecimento prévio do aluno, participando do processo de aprendizagem [...].

A educação geográfica pode ser promotora da cidadania, pela leitura de mundo que poderá despertar nos alunos e levando em conta seus conhecimentos prévios para o

15 Tal forma de trabalho pedagógico é referendada pelos Parâmetros Curriculares Nacionais - PCNs (BRASIL, 1997).

${ }_{16}$ Tal forma de trabalho pedagógico é pautada pela Base Nacional Comum Curricular - BNCC (BRASIL, 2017). 
desenvolvimento de ações de intervenção local. Para além disso, a educação geográfica atende e defende os Direitos Humanos frente a inúmeros desafios, pois um "[...] mundo mais justo interpela, decisivamente, uma educação geográfica que deve estar empenhada na concretização dos direitos sociais dos vários grupos humanos" (SOUTO GONZÁLEZ; CLAUDINO, 2004, p. 11).

Os conhecimentos prévios podem ser valorizados e usados para suporte para novas aprendizagens por meio da problematização de questões sociais e ambientais da localidade no cotidiano dos alunos. Isto posto, a educação geográfica, voltada para a formação cidadã, pode

[...] superar as aprendizagens repetitivas e arbitrárias e passar a adotar práticas pedagógicas que invistam nas habilidades: análises, interpretações e aplicações em situações práticas; trabalhar a cartografia como metodologia para a construção do conhecimento geográfico, a partir da linguagem cartográfica; analisar os fenômenos em diferentes escalas; compreender a dimensão ambiental, política e socioeconômica dos territórios. (CASTELLAR, 2005, p. 222).

Nesse caminho, a educação geográfica contribui para analisarmos e interpretarmos, criticamente, os fenômenos e seus impactos tanto no local quanto no global, como foi afirmado anteriormente, e, nesse sentido, adquirimos, como professores e alunos, uma consciência de cidadania planetária. Esta é entendida como

[...] que cada ser humano, cada ciudadano, independentemente de su sexo, religión, ideologia, cultura o lugar em que viva, forma parte de uma sociedad planetária, una sociedad que assume que el planeta es nuestra casa y que hemos de encontrar el caminho para seguir viviendo juntos en el mismo. (GARCÍA PÉREZ; MORENO FERNANDEZ; RODRÍGUEZ MARÍN, 2015, p. 34) ${ }^{17}$.

O aluno, na concepção da cidadania planetária, deve se preocupar com temas gerais, amplos e de interesse universal, apresentar as problematizações e contradições dos mais diversos assuntos, sem nunca deixar a sua singularidade de ser humano e de cidadão (GARCÍA PÉREZ; MORENO FERNANDEZ, RODRÍGUEZ MARÍN, 2015). Isto posto, destacamos que os problemas de ordem global devem ser pensados no âmbito local, como a desigualdade social, a fome, o desemprego, a precariedade das moradias, problemas de ordem sanitária, violências de gênero, de raça, religiosas, dentre outros.

Nesse sentido, a educação geográfica possibilita um caminho para pensarmos o papel do ensino de Geografia e qual aluno queremos formar. Ela contribui para o desenvolvimento

\footnotetext{
${ }_{17}$ [...] cada ser humano, cada cidadão independentemente de seu sexo, religião, ideologia, cultura ou lugar em que viva, forma parte de uma sociedade planetária, uma sociedade que assume que o planeta é a nossa casa e que temos que encontrar o caminho para seguir vivendo juntos nele" (tradução nossa).
} 
de atividades cívicas de responsabilidade e de pertencimento à localidade dos estudantes, desenvolve o compromisso de solucionar problemas que são caros aos seres humanos, em uma perspectiva de empatia, e pode promover as capacidades superiores intelectuais de análise e síntese do pensamento geográfico (ARAYA PALACIOS; ÁLVAREZ BARAHONA, 2019).

Estamos, portanto, alinhados com um ensino de Geografia que procura discutir e colocar em prática elementos de uma cidadania, tanto global como local. Um ensino que pode estar presente nos espaços escolares, para que os alunos possam compreender o espaço geográfico em suas contradições e complexas relações sociais montadas por meio da ação antrópica e agir de forma ativa nesse espaço.

\subsection{Considerações sobre a Cidadania na Educação}

A democracia que experimentamos na contemporaneidade é composta por contradições e problemas externos e internos. Neste sentido, Matos (2005) problematiza o conceito e o apresenta como tendo contradições a serem superadas constantemente pelas sociedades. Além disso, o referido autor admite que devemos deixar de ver a democracia por uma perspectiva engessada, vertical e relacionada à organização política formal na figura do Estado. Diante disso, Matos (2005, p. 43, grifo do autor) expõe que a democracia

[...] representa uma forma de vida, uma acção política em aberto, levada cabo por pessoas, na complexidade das relações e dos processos locais, regionais e globais [...] Esta acção política tem sempre o propósito de mudança no sentido de modificar e melhorar as condições das pessoas envolvidas e da sociedade em geral e, por isso mesmo, envolve a transformação das pessoas e das condições do seu acesso à participação nas comunidades. E essa participação passa necessariamente pelo diálogo social que dá o poder às pessoas para se envolverem em processos de enunciar problemas, de tomar decisões e de resolver esses problemas.

Nesse sentido, o poder de manifestações, participações, ações e fenômenos históricos, sociais e culturais advém da ação política do coletivo e pode ser participativo. Esses grupos, por meio dos instrumentos legais, garantidos pela democracia, é que asseguram as relações e a vida social da população, no sentido de garantia de direitos e de uma qualidade de vida digna. Assim, a democracia está intimamente relacionada com a Educação (MATOS, 2005).

Além disso, admitimos a ênfase no aspecto coletivo na construção e manutenção da democracia. Esse coletivo que movimenta e transforma as relações sociais no espaço 
geográfico, global e local. Isto posto, podemos complementar com a ideia de Bazolli, Dantas e Coelho (2018, p. 947), que afirmam que

O grande desafio das democracias, sejam elas novas ou já consolidadas, é a necessidade de aperfeiçoamento e aprofundamento das instituições democráticas, de forma que se permita a ampliação do direito de exposição/vocalização das preferências dos cidadãos e o controle público do exercício do poder.

A democracia deve aprimorar meios para o cidadão desenvolver a sua "voz" e sua "vez" no amplo leque de instrumentos que ela criou para o coletivo. Dewey afirma que "[...] uma democracia é mais do que uma forma de governo; é, essencialmente, uma forma de vida associada, de experiência conjunta e mutuamente comunicada" (DEWEY, 1979, p. 93 apud MURARO, 2013, p. 824). Neste sentido, Paulo Freire (1989, p. 80, grifo nosso) traz como contribuição a ideia de que a democracia

[...] antes de ser forma política, é forma de vida, se caracteriza, sobretudo por forte dose de transitividade de consciência no comportamento do homem. Transitividade que não nasce e nem se desenvolve a não ser dentro de certas condições em que o homem seja lançado ao debate, ao exame de seus problemas e dos problemas comuns. Em que o homem participe.

Desta forma, o elemento chave da democracia é a vivência e prática da cidadania nas relações sociais com participação ativa e livre. Essa participação está incorporada à existência do ser humano e tem como um dos elementos chave a reflexão crítica e ações frente aos problemas sociais que atingem o coletivo. Esses autores ${ }^{18}$ concordam que a democracia é, em essência, a discussão pública dos problemas sociais em comum, estende-se além do ato do voto e pressupõe um coletivo que dialoga, reflete, compartilha ideias e comportamentos solidários e justos e atua para poder superar esses problemas locais.

Salientamos que não é pretensão desta investigação realizar um histórico da construção da cidadania no Ocidente e no Brasil. Contextualizamos a democracia e a cidadania como forma de vida presente no cotidiano do coletivo, em destaque na Educação e no ensino de Geografia no Brasil, para refletir melhor sobre as ações desenvolvidas no Projeto "Nós Propomos! cidadania e inovação na educação geográfica".

Assim, como derivado da democracia, a ideia de cidadania foi sendo construída historicamente no Brasil, e hoje é basilar em documentos oficiais e no cotidiano brasileiro. A vida social nos territórios construídos pela ação antrópica impõe-nos a ideia de cidadania e requer um componente que “[...] supõe a definição prévia de uma civilização que se quer, o

\footnotetext{
${ }_{18}$ Paulo Freire foi leitor das obras de John Dewey e incorporou aportes teóricos em sua obra.
} 
modo de vida que se deseja para todos, uma visão comum do mundo e da sociedade, do indivíduo enquanto ser social e das regras de convivência” (SANTOS, 2004, p. 17).

A cidadania, portanto, é uma construção histórica, pois apresenta conteúdo político e de organização social, cultural e econômica que foi consolidada, legalmente, com a Constituição Federal do ano de 1988. Nessa perspectiva de análise, Deon e Callai (2018, p. 270) realizam a seguinte reflexão

\begin{abstract}
A Constituição Federal passa a assegurar em lei os direitos que na história da cidadania no Brasil foram negados à grande parte da população, tida como não cidadã (negros, pobres, mulheres, analfabetos), pois ao longo de toda a História a cidadania sempre foi um direito para poucos, existindo 'cidadania' e 'cidadanias', ou 'os mais cidadãos' e os 'menos cidadãos'.
\end{abstract}

Diante do exposto, podemos inferir que o exercício da cidadania passa pela apropriação das leis e códigos sociais pelo coletivo, no sentido deste coletivo saber os mecanismos dessa cidadania e exercê-la no seu cotidiano, de forma ética e empática. A cidadania é a materialização de práticas em convivência do cidadão e se estende a todos como seus beneficiários. Como forma de contribuir para o entendimento sobre a cidadania, Cavalcanti e Sousa (2014, p. 5, grifo nosso) salientam que

[...] cidadania está ligada à participação da vida coletiva incluindo reivindicações de inclusão social, de respeito à diversidade e de direitos mais amplos para melhores condições de vida e de sobrevivência. Trata-se de uma noção de cidadania que exercita o direito a ter direitos, aquela que cria direitos, no cotidiano, na prática da vida coletiva e pública', destacandose sua dimensão territorial, formulada, conforme mencionado anteriormente, em termos de direito à cidade.

Notamos, pelo trecho citado, que a cidadania está intimamente relacionada com a ação de participar no cotidiano de forma coletiva e com a identidade de pertencimento a um dado território. Desta forma, a cidadania relaciona-se ao conceito de cidadão em relação à sua geograficidade, ou seja, como parte da condição humana, dentro de uma consciência política e social em um ideal de bem-estar e felicidade em determinados contextos. Em consonância com essa concepção, Oliveira (1999, p. 117, grifo nosso) salienta que ser cidadão é

[...] o indivíduo normalizado, ou seja, vivendo sob normas, conformadas pelo desenvolvimento material e cultural da sociedade a que pertence, acordadas por um contrato social (estatuto de direitos e deveres) e ajuizadas e reguladas pelo Estado. Portanto, a cidadania depende da condição material e cultural que possui um indivíduo, concebida como herança histórica, da posição social que ele ocupa na sociedade em questão e do nível de participação nas decisões que definem os seus rumos nas 
diferentes escalas social e geográfica, da comunidade local ao poder do Estado nacional.

Assim, salientamos o caráter participativo e decisório em diferentes escalas, em especial a local que se relaciona diretamente com a vida das pessoas. Podemos entender a cidadania como algo criado e recriado com base nas lutas políticas "[...] a favor da recriação da sociedade injusta, a ceder seu lugar a outra menos injusta e mais humana" (FREIRE, 2014, p. 100). A cidadania é construída no coletivo, por meio de processos de tomada de decisão da população. Nesse sentido, o processo de ensinar para o desenvolvimento da autonomia do aluno é um ato de reprodução e ampliação da cidadania por uma sociedade humanizada.

Para pensarmos a cidadania a partir dessas contribuições, podemos entender que ela é parte da complexidade das relações humanas, construídas historicamente e ligadas aos territórios e modelamentos culturais diversos. Para além de ser dinâmica nos tempos e espaços, ela está intimamente ligada ao cotidiano e à participação social coletiva. Apontamos alguns estudos que discutem a importância da formação cidadã para o convívio em sociedades democráticas, dentre eles: Oliveira (1999); Vesentini (2004); Santos (2004); Callai (2011); Souza e Leite (2018); e Cavalcanti (2012).

Com base no que foi discutido temos que ser cidadão "[..] é multidimensional. Cada dimensão se articula com as demais na procura de um sentido para a vida. Isso é o que dele faz o indivíduo em busca do futuro, a partir de uma concepção de mundo". (SANTOS, 2004, p. 56).

Concordamos com tal concepção na medida em que a expressão das necessidades da atuação de um cidadão pode levá-lo a projetar seu futuro em uma vida digna, com a livre e consciente manifestação cultural, de crenças e práticas sociais, com participação política, com estabelecimento de uma qualidade de vida adequada para seu desenvolvimento humano e com apropriação ativa no local de vivência de forma ética e consciente.

Diante do exposto, apresentamos a figura 1 buscando sintetizar as ideias sobre cidadania.

Figura 1 - Elementos da cidadania 


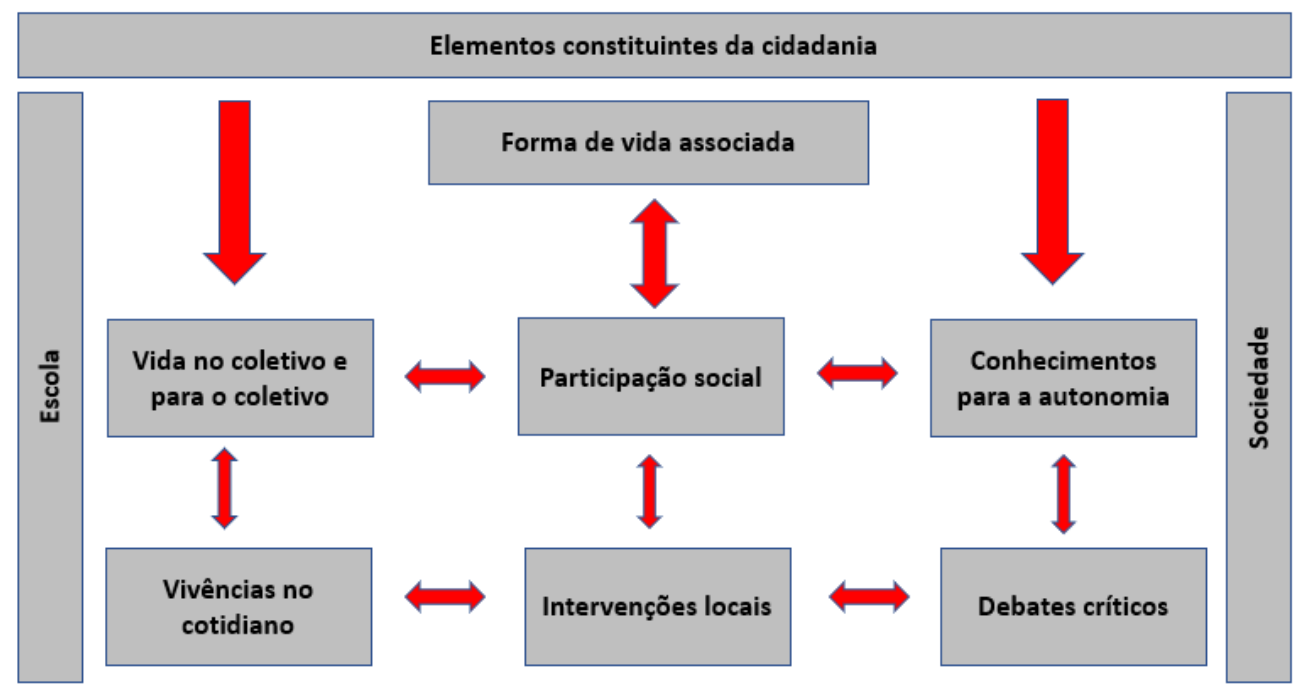

Fonte: elaborado pelo autor

A cidadania possui como componentes centrais em uma forma de vida associada (DEWEY, 1979, apud MURARO, 2013), a participação social, a vida no coletivo e para o coletivo, a vivência no cotidiano, os debates críticos, os conhecimentos para autonomia, as intervenções locais, dentre outros. Esses componentes devem estar presentes na Escola em diálogo com a sociedade para fazerem sentido no cotidiano social, ou seja, numa escola que busca ser promotora de práticas cidadãs.

\subsection{A presença da cidadania em documentos oficiais}

Para esta investigação, elencamos sete documentos que admitimos ser de grande importância, porque destacam a relevância da cidadania no cotidiano do ser humano, tendo em vista sua formação cidadã ativa. Os referidos documentos são: 1 e 2: Carta Internacional da Educação Geográfica (1992; 2016); 3: a Carta da Comissão da Comunidade Europeia (2001); 4: a Constituição Brasileira (1988); 5: a Lei de Diretrizes e Base (1996); 6: os Parâmetros Nacionais Curriculares (1997); e 7: a Base Nacional Comum Curricular (2017). Neste sentido, a cidadania adquire um caráter fundamental por estar prevista nos referidos documentos, nacionais e internacionais. Tais documentos asseguram a sua legitimidade e valor educativo.

A Comissão para a Educação Geográfica (CEG) da União Geográfica Internacional (UGI) $^{19}$, fundada em 1952, tem como objetivo produzir documentos internacionais que valorizam a educação geográfica, a cooperação internacional em pesquisas acadêmicas e o estabelecimento de redes colaborativas (BROOKS; QIAN; SALINAS-SILVA, 2017). Nesse

\footnotetext{
19 Para mais informações: http://www.igu-cge.org Acesso em: 10 de jan. 2020.
} 
sentido, a UGI elaborou documentos que serviram de referência para vários países traçarem planos e metas no tocante ao ensino de Geografia. Desta forma, a CEG e a UGI têm como objetivos,

[...] fornecer legitimidade para as produções acadêmicas em educação geográfica, para que, no futuro, os formuladores de políticas e desenvolvedores de currículo tenham acesso a uma base de informações sobre formas mais bem sucedidas e capazes de articular, delinear e estruturar o currículo de geografia para educar e informar jovens de todas as idades. (BROOKS; QIAN; SALINAS-SILVA, 2017, p. 17).

No plano internacional, a Carta Internacional da Educação Geográfica da Comissão de Educação Geográfica $(\mathrm{CGE})^{20}$, do ano de 1992, foi ratificada na Assembleia Geral da União Geográfica Internacional (UGI), no $27^{\circ}$ Congresso Internacional de Geografia, realizado em Washington D.C., nos Estados Unidos.

O documento destaca que “[...] a educação geográfica é indispensável para o desenvolvimento de cidadãos responsáveis e ativos no mundo presente e no futuro" (CGE, 1992, p. 3). Para além, a educação geográfica tem a dimensão de "[...] encorajar os indivíduos à compreensão não só dos direitos, mas também, dos deveres dos indivíduos, grupos sociais e nações uns em relação aos outros" (CGE, 1992, p. 9).

Atualmente está em vigor a Carta Internacional da Educação Geográfica, ratificada em Pequim, no ano de 2016. Nessa carta aparece por três vezes a palavra "cidadãos" e não aparece a palavra cidadania e nem ações de uma educação geográfica voltada para a cidadania, como importantes para os alunos nas esferas global e local. Entendemos tal documento como conceitualmente fraco, pois não explicita claramente os objetivos de forma sistematizada. A carta explicita que

La Geografía ayuda a que la gente desarrolle un pensamiento critico relativo a vivir de forma sostenible, local y globalmente, y a que la gente actúe de forma consecuente [...] La educación geográfica es vital para preparar a la próxima generación de personas con los conocimientos, los procedimientos y las prácticas necesarios para valorar, cuidar, y tomar decisiones razonadas para el planeta. (CGE, 2016, p. 8) ${ }^{21}$.

\footnotetext{
${ }^{20}$ Encontrada em inglês como "Commission of Geographical Education of International Union Geographical”. Versão em português disponível em: http://www.igu-cge.org/wp-content/uploads/2018/02/15.-Portuguese.pdf. Acesso em: 10 ago. 2019.

21 “A Geografia ajuda as pessoas a desenvolver um pensamento crítico relativo a viver de forma sustentável, local e globalmente e a atuar de forma consciente [...] A educação geográfica é vital para preparar as próximas gerações de pessoas com os conhecimentos, com os procedimentos e práticas necessárias para valorizar, cuidar e tomar decisões razoáveis" (tradução nossa).
} 
Desta forma, não contempla a Educação para a cidadania presente em documentos brasileiros. Admite, porém, a possibilidade de a educação geográfica formar um pensamento crítico e para a tomada de decisões pelos alunos.

Apesar disso, os elementos discutidos nas duas cartas referidas reforçam os laços de cooperação, em uma comunidade voltada à Educação. $\mathrm{O}$ despertar de um sujeito ativo na sociedade em seus direitos e deveres, assim como um sujeito que age localmente para promover o bem-estar e a justiça social, são algumas das ideias contidas nos referidos documentos oficiais.

Um terceiro documento internacional relevante é o Comunicado da Comissão "Tornar o espaço europeu de aprendizagem ao longo da vida uma realidade", feito pela Comissão da Comunidade Europeia (2001). Tal documento destaca a importância de se promover ações efetivas em prol de uma cidadania e de uma participação ativa local, nos territórios europeus.

Temos que a cidadania ativa é "[...] a participação na vida cultural, econômica, política/democrática e/ou social dos cidadãos na sociedade como um todo e na sua comunidade" (CCE, 2001, p. 39), enquanto que a participação ativa é "[...] o processo que consiste em investir os indivíduos do poder de assumir iniciativas responsáveis com vista a determinar a sua própria vida e a da sua comunidade ou sociedade em termos econômicos, sociais e políticos" (CCE, 2001, p. 39).

No plano nacional, temos documentos legais que amparam e justificam a cidadania como elemento formador do sujeito. Podemos notar a ideia de cidadania inicialmente presente na chamada - Constituição brasileira, popularmente denominada de "Constituição Cidadã", pelo contexto histórico em que foi elaborada, no ano de 1988:

Art. $1^{\circ}$ A República Federativa do Brasil, formada pela união indissolúvel dos Estados e Municípios e do Distrito Federal, constitui-se em Estado Democrático de Direito e tem como fundamentos: I - a soberania; II - a cidadania; III - a dignidade da pessoa humana; IV - os valores sociais do trabalho e da livre iniciativa; V - o pluralismo político. Parágrafo único. Todo o poder emana do povo, que o exerce por meio de representantes eleitos ou diretamente, nos termos desta Constituição. (BRASIL, 1988, grifo nosso).

Nesse sentido, podemos notar, logo no início da Carta Magna, o fator preponderante do termo, o fato de que o Estado assume o dever para com a cidadania. Sobre a Educação, o referido documento salienta

[...] direito de todos e dever do Estado e da família, será promovida e incentivada com a colaboração da sociedade, visando ao pleno 
desenvolvimento da pessoa, seu preparo para o exercício da cidadania e sua qualificação para o trabalho (BRASIL, 1988, grifo nosso).

Notamos que a formação cidadã é fator integrante da Educação, e o Estado deve assegurar, manter e desenvolver tal formação em todo o território nacional. Essa garantia amplia-se em outro documento oficial de grande importância na área educacional. A Lei $\mathrm{n}^{\mathrm{o}}$ 9.394, de 20 de dezembro de 1996, a Lei de Diretrizes e Bases (LDB), no seu artigo 2 coloca que

A Educação, dever da família e do Estado, inspirada nos princípios de liberdade e nos ideais de solidariedade humana, tem por finalidade o pleno desenvolvimento do educando, seu preparo para o exercício da cidadania e sua qualificação para o trabalho. (BRASIL, 1996, grifo nosso).

Em 1997, o governo federal publicou os Parâmetros Nacionais Curriculares - PCNs ${ }^{22}$. Desta forma, esse conjunto de documentos oficiais acaba por assegurar, inclusive no ensino de Geografia, a formação cidadã.

A Geografia é uma área de conhecimento comprometida em tornar o mundo compreensível para os alunos, explicável e passível de transformações. Neste sentido, assume grande relevância dentro do contexto dos Parâmetros Curriculares Nacionais, em sua meta de buscar um ensino para a conquista da cidadania brasileira. (BRASIL, 1997, p. 26, grifo nosso).

Com essa concepção de formação para a cidadania, temos que

O objetivo dos PCNs era garantir que todas as crianças e jovens brasileiros, mesmo em locais com condições socioeconômicas desfavoráveis, tivessem o direito de usufruir do conjunto de conhecimentos reconhecidos como necessários para o exercício da cidadania. (AZEVEDO; LASTÓRIA; FERNANDES, 2019, p. 494).

Em 2018, o governo federal lançou outro documento de ampla escala, a Base Nacional Comum Curricular - $\mathrm{BNCC}^{23}$. Nesse documento, o ensino de Geografia é apresentado como fundamental para

[...] desenvolver o pensamento espacial, estimulando o raciocínio geográfico para representar e interpretar o mundo em permanente transformação e

22 Os Parâmetros Curriculares Nacionais, instaurados no ano de 1997, indicam conteúdos, temas e pressupostos teórico-metodológicos para o ensino básico no Brasil. São orientações gerais à elaboração de currículos.

23 A BNCC deve nortear os currículos dos sistemas e redes de ensino das Unidades Federativas, como também as propostas pedagógicas de todas as escolas públicas e privadas de Educação Infantil, Ensino Fundamental e Ensino Médio, em todo o Brasil. A BNCC estabelece conhecimentos, competências e habilidades que se espera que todos os estudantes desenvolvam ao longo da escolaridade básica. Disponível em: http://basenacionalcomum.mec.gov.br/. Acesso em: 10 ago. 2019. 
relacionando componentes da sociedade e da natureza. Para tanto, é necessário assegurar a apropriação de conceitos para o domínio do conhecimento fatual (com destaque para os acontecimentos que podem ser observados e localizados no tempo e no espaço) e para o exercício da cidadania. (BRASIL, 2017, p. 358, grifo nosso).

Notamos que a BNCC, assim como os PCNs, explicita a formação cidadã no ensino de Geografia $^{24}$. Essa análise é vital, pois contribui para pensarmos as múltiplas formas que a formação cidadã adquire, no sentido de promover a justiça social e a igualdade de participação popular no Brasil, por meio da Educação.

Para o aluno desenvolver o protagonismo na escola, é necessário mobilização coletiva por parte da equipe escolar, na construção de uma escola democrática voltada à formação cidadã. Portanto, torna-se fundamental discutir a importância da participação discente na constituição do cidadão brasileiro, por meio de projetos escolares.

A participação como estratégia/meio de construção política é incorporada à estrutura organizacional do Estado na origem da Constituição Federal do ano de 1988, com princípios de resistência e de luta pelas liberdades democráticas, lideradas pelos movimentos sociais. No que se refere à ampliação da participação social no Brasil, a nova Constituição possibilitou

[...] a formação de espaços participativos como os conselhos e conferências, estas últimas com ênfase na primeira década dos anos 2000 de caráter mais formal para acolher as interações e vozes entre sociedade civil, movimentos sociais e Estado (BAZOLLI; DANTAS; COELHO, 2018, p. 2450).

Notamos no trecho anterior de Bazolli, Dantas e Coelho (2018) uma dimensão de valorização da participação política e social estabelecida na Magna Carta que abre margem para o ensino de Geografia possibilitar o foco na formação cidadã. Destacamos, portanto, que, a partir dos referidos documentos oficiais, a educação geográfica é mencionada como responsável para promover a cidadania.

A expressão participação social abrange, segundo Montoro (1992, p. 23), “[...] a atuação organizada e responsável dos múltiplos setores da sociedade, na solução de problemas coletivos e na promoção do bem comum no sentido de alcançar uma justiça social". Participar abrange uma gama de ações do coletivo, em detrimento do individual e atinge diversos campos da sociedade.

Nos PCNs de Geografia, a participação discente deve ser estimulada na Escola, afinal, ela se constitui como um elemento da democracia que pode ser ensinado e aprendido.

\footnotetext{
${ }^{24}$ Não nos deteremos aqui nas concepções de Educação, ensino ou mesmo de ser humano que a BNCC traz, pois na presente investigação o que é preciso considerar é que o documento sinaliza a formação cidadã, apoiada na Constituição Federal (1988) e na Carta Internacional da Educação Geográfica (1992).
} 
[...] A escola será um lugar possível para essa aprendizagem, se promover a convivência democrática no seu cotidiano, pois aprende-se a participar, participando. No entanto, se a escola negar aos alunos a possibilidade de exercerem essa capacidade, estará, ao contrário, ensinando a passividade, a indiferença e a obediência cega. É aqui que a importância do convívio escolar ganha amplitude, a fim de tomar a escola como espaço de atuação pública dos alunos. (BRASIL, 1997, p. 41, grifos nosso).

Nesse sentido, Bazolli, Dantas e Coelho (2018, p. 950) lembram-nos que "A participação se concretiza, quando permite que os sujeitos façam parte das decisões que lhes dizem respeito, seja nos aspectos políticos, sociais, culturais ou econômicos". Os referidos autores concluem que a participação "[...] efetiva não pode ser mensurada simplesmente pela presença física dos indivíduos no processo. É necessária a autonomia, o direito de se manifestar e/ou influenciar de algum modo os processos de tomada de decisão" (BAZOLLI; DANTAS; COELHO, 2018, p. 951).

A participação discente está ligada à autonomia do indivíduo, discutida por Freire (2014), no sentido de conhecer e entender como manusear os instrumentos da democracia voltada às práticas da cidadania. Isto pode ocorrer no ambiente escolar por meio de projetos educativos.

A participação também está ligada à identificação "[...] del estudiante com el centro escolar y la implicación y el compromisso con las tareas. Según esto un prerrequisito para la participación es 'sentirse parte', y esto apunta a los sentimentos de inclusión, de ser aceptado y respetado en la escuela" (PINEDA-AFONSO, 2015, p. 56) ${ }^{25}$.

As Escolas podem educar, com coerência, para a participação social nas mais diversas esferas da vida coletiva, nos espaços públicos e privados e nas amplas instituições sociais que compõem a vida humana (GARCÍA PÉREZ; MORENO FERNANDEZ, RODRÍGUEZ MARÍN, 2015). Para que isto seja realizado, os projetos educativos e as instituições escolares precisam “[...] adoptar un enfoque curricular más integrado y global, assumiendo la opción de trabajar em torno de problemas sociales y ambientales relevantes, como el camino más coerente con una educación para uma cidadania activa y partcipativa" (GARCÍA PÉREZ; MORENO FERNANDEZ, RODRÍGUEZ MARÍN, 2015, p. 36$)^{26}$.

\footnotetext{
25 “[...] do estudante com a unidade escolar e com a implicação com as tarefas. Segundo este pré-requisito para a participação é 'sentir-se parte', e isto aponta ao sentimento de inclusão, de ser aceito e respeitado na Escola" (tradução nossa).

26 “"...] adotar um enfoque curricular integrado e global, assumindo a opção de trabalhar em torno de problemas sociais e ambientais relevantes, como o caminho mais coerente com uma educação para a cidadania ativa e participativa" (tradução nossa).
} 
A Escola pode ser um espaço de aprendizagem constante e integrado ao local e à vida do aluno. Nessa perspectiva, projetos que estimulem a participação coletiva dos alunos alinham-se ao que está colocado nos documentos oficiais, citados anteriormente, e ao que a educação geográfica defende como formação cidadã.

Entendemos ser necessário superar entraves e problemáticas presentes no ensino tradicional de Geografia para avançar em direção a um ensino mais inovador, que forme cidadãos críticos e comprometidos com a participação efetiva dos estudantes nas discussões e nos encaminhamentos coletivos. Esta participação pode começar no local e no cotidiano,

[...] trabalhando o lugar considerando o cotidiano do aluno como conteúdo a ser compreendido, com uma lógica de abordar cada fenômeno na perspectiva dialética da complexidade do espaço, contextualizando-os nos vários níveis de escala social. Neste sentido não é raro chegar ao cotidiano a partir de discussões de problemas mais globais. (CALLAI, 2011, p. 27).

Desta forma, é fundamental, numa sociedade globalizada, pensar e praticar um ensino de Geografia que trabalhe com questões locais e a problematização do cotidiano, a fim de desenvolver a autonomia e a criticidade do aluno. Neste sentido, admitimos que o projeto Nós Propomos! como um caminho possível. 


\section{O TRABALHO DE CAMPO E O ESTUDO DO MEIO}

"O trabalho de campo não deve constituir um fim em si mesmo, (CLAUDINO, 2018, p. 267)

Nesta seção apresentamos alguns apontamentos sobre o trabalho de campo para a Geografia e para o ensino de Geografia, o nosso alinhamento ao uso do referencial teórico do estudo do meio e qual a relação de ambos no desenvolvimento do "Projeto Nós Propomos! cidadania e inovação na educação geográfica".

Destacamos que, termos como visita técnica, passeio, aula de campo, saída de campo, aula-passeio, pesquisa de campo, trabalho de campo, excursão didática, dentre outros, são usados, por muitos docentes, para designar atividades fora da sala de aula. Todas essas atividades são entendidas, na presente investigação, como atividades que integram os procedimentos do estudo do meio e que estão presentes no projeto Nós Propomos!.

\subsection{O trabalho de campo}

O trabalho de campo é inerente ao desenvolvimento da Geografia como Ciência do conhecimento, além de ser parte fundamental do método de trabalho dos geógrafos. $\mathrm{Na}$ Geografia tradicional, de fins do século XIX, admitia-se o trabalho de campo como "[...] la base física y su interacción con la vida del hombre para caracterizar los paisajes, el análisis de la relación entre el ser humano y la naturaliza" (FERNANDES; GARCIA MONTEAGUDO; SOUTO GONZÁLEZ, 2016, p. 3$)^{27}$.

No século XX, o trabalho de campo ganha contornos e relevância também na área educacional, em especial no ensino de Geografia, no sentido de auxiliar na compreensão do espaço vivido pelos alunos. O geografo francês Jean Jacques Reclus admite, em sua obra "L.Homme et la Terre" (O homem e a Terra, tradução nossa), que a Escola deve estar em ampla relação com natureza para promover o aprendizado dos alunos. Segundo Reclus (1905, p. 444),

[...] a escola verdadeiramente liberada da antiga servidão só pode ter franco desenvolvimento na natureza. $\mathrm{O}$ que nos dias atuais é considerado, nas escolas, como festas excepcionais, passeios, excursões nos campos e nas florestas, nas margens dos rios e nas praias deveria ser a regra. Porque é

27 “[...] a base física e sua interação com a vida do homem para caracterizar as paisagens, a análise da relação com o ser humano e a natureza" (tradução nossa) 
apenas ao ar livre que se pode conhecer a planta, o animal, o trabalhador e é onde aprendemos a observar, a fazer uma ideia precisa e coerente do mundo exterior.

Em 1966, a Organização das Nações Unidas para a Educação, Ciência e Cultura UNESCO, produziu um livro denominado L'Enseignement de la géographie ${ }^{28}$ (O ensino de Geografia, tradução nossa). Esse livro levanta, como possibilidade, o uso de trabalho de campo como promotor de um ensino de Geografia significativo.

Diante disto, a referida obra afirma que “[...] Dès lors, il faut habituer l'élève à l'observation du milieu géographique où il vit, du milieu physique aussi bien que des activités humaines et des manifestations extérieures de ces activités" (UNESCO,1966, p. 18) ${ }^{29}$. Neste sentido, destaca que como atividade promovedora de um ensino de Geografia comprometido o

[...] L'étude du milieu local a pour objet de mettre les élèves en contact avec les faits réels: l'école et ses environs, puis le village ou la ville, avec ses quartiers, son site, as population, ses activités; enfin, le milieu naturel, son relief, son climat, les eaux, la végétation, la mise en valeur de la localité (UNESCO, 1966, p. 183) . $^{30}$.

No Brasil, o trabalho de campo foi impulsionado pela Associação dos Geógrafos brasileiros (AGB) ${ }^{31}$ até a década de 1970, quando houve mudanças nos estatutos nos quais foram retirados da grade de encontros da entidade. Em fins da década de 1990, os trabalhos de campo voltaram à cena e passaram a ser praticados em consonância com outros estudos geográficos.

Os trabalhos de campo na trajetória da Geografia brasileira se alinham a correntes científicas em cada momento histórico e seus contextos. No caso do início da AGB até a década de 1970, a corrente francesa empirista predominava. A partir da mesma década, a corrente teorético-quantitativa passa a negar os trabalhos de campo em prol das grandes teorias. Na década de 1990, temos a corrente da Geografia Crítica que desenvolve um equilíbrio entre as bases teóricas e as práticas do trabalho de campo para o desenvolvimento da Geografia no Brasil (ALENTEJANO; ROCHA-LEÃO, 2006).

\footnotetext{
28 Para mais informações https://unesdoc.unesco.org/ark:/48223/pf0000133922. Acesso em: 28 out. 2019.

29 “"...] Assim, você precisa se acostumar com o aluno observando o ambiente geográfico onde ele mora, também do ambiente físico embora as atividades humanas e manifestações externas dessas atividades" (tradução nossa).

30 "O objetivo de estudar o meio ambiente local é colocar os alunos em contato com os fatos real: a escola e seus arredores, depois a vila ou a cidade, com seus distritos, seu local, sua população, suas atividades; finalmente no meio natural, seu relevo, seu clima, as águas, o vegetação, valorização da localidade"(tradução nossa).

31 Associação dos geógrafos brasileiros. Para mais informações, confira: https://www.agb.org.br/. Acesso em: 15 out. 2019.
} 
Para além disso, faz-se importante mencionar a abordagem crítica de Thomaz Júnior (2005, p. 34), que afirma a importância da discussão do trabalho de campo em um patamar “[...] teórico, que nos permita entendê-lo como um momento ímpar na produção de conhecimento alternativo, mediatizado através de uma prática teoricamente orientada, momento consagrador do exercício da prática teórica".

Os autores Alentejano e Rocha-Leão (2006) e Lacoste (2006) ampliam nossa compreensão sobre a importância do trabalho de campo ao exporem que o mesmo não se pode limitar somente à prática (empirismo), sob pena de se esvaziar teoricamente e, com isso, não relevar os fenômenos geográficos a serem estudados, mas, sim, deve articular-se à fundamentação teórica para promover uma adequada interpretação geográfica da realidade.

Kayser (1985) e Thomaz Júnior (2005) consideram que o trabalho de campo deve fluir constantemente entre o pensamento e o concreto nas ações de pesquisa do geógrafo, e que este deve começar a levantar hipóteses com base no reconhecimento do campo, com posterior olhar para as teorias.

Baseado na ciência geográfica e nos conhecimentos sobre o trabalho de campo, como metodologia de investigação e produção científica, focamos no seu valor para o ensino de Geografia. Diante disso, elencamos autores que trabalham em uma perspectiva de formação para a cidadania e de forma crítica

Existem vários estudos sobre a relevância do trabalho de campo no ensino de Geografia, como os de Cavalcanti (2002, 2007), Oliveira y Assis (2009); Fernandes (2010), Silveira; Crestane; Frick (2014), Fernandes; Lastória (2014) $)^{32}$, entre outros. Tais estudos indicam que o trabalho de campo se constitui em um agente potencializador de aprendizagens significativas para os alunos na Educação Básica, para compreensão do espaço pelos alunos.

Ao tratar sobre o conceito de trabalho de campo, Fernandes; Garcia Monteagudo; Souto González (2016) destacam que este

[...] posibilita la formación ciudadana, puesto que valoriza el estudio de los
lugares y territorios, en diferentes ambientes y es abordado a partir de
temáticas complejas o que se interrelacionan como en el análisis de las
relaciones del espacio rural y urbano, en identificación de los diferentes
paisajes naturales y el reconocimiento de las marcas del tiempo en el
proceso de producción del espacio. (FERNANDES; GARCIA
MONTEAGUDO; SOUTO GONZÁLEZ, 2016, p. 18) ${ }^{33}$.

32 Focamos em estudos produzidos no Brasil sobre os temas trabalho de campo e estudo do meio no ensino de Geografia.

33 “"...] possibilita a formação cidadã, pois valoriza o estudo dos lugares e territórios, em diferentes ambientes, sendo abordado por meio de temas complexos [...] e o reconhecimento das marcas do tempo no processo de produção do espaço" (tradução nossa) 
Reconhecemos que o trabalho de campo descende da ideia de compreensão do espaço e impacta diretamente na formação cidadã, na medida em que possibilita "[...] posible investigar no sólo sobre el territorio, sino también sobre las relaciones interpersonales en tareas colectivas. Un medio local donde encontramos problemas semejantes, lo que nos permite relacionar dichos fenómenos en una escala global" (CLAUDINO; SOUTO GONZÁLEZ; ARAYA PALACIOS, 2018, p. 64) ${ }^{34}$.

Seguindo essa linha de pensamento, o estudo de Sansolo (2000) traz como contribuição pensar e praticar o trabalho de campo no ensino de Geografia em uma perspectiva de pesquisa. Essa pesquisa se dá em dois momentos, sendo o primeiro denominado de "excursão de reconhecimento", para em seguida ocorrer a "investigação minuciosa". O primeiro momento é destinado ao reconhecimento do campo e das potencialidades de aprendizagem, enquanto o segundo momento é o ato de análise em si.

Neste sentido, as ações de observação, exploração, entrevistas e análises dos estudantes são fundamentais, uma vez que "[...] os problemas específicos serão averiguados em campo, experimentados in loco, onde se pretende estabelecer uma aproximação da realidade" (SANSOLO, 2000, p. 143). A partir dessas ações obtém-se material para averiguar os problemas enfocados a partir da realidade dos estudantes.

Desta forma, o trabalho de campo exploratório na pesquisa geográfica e no ensino de Geografia é central para despertar nos alunos o seu protagonismo, desenvolver neles a proximidade com o espaço geográfico e com suas contradições histórico-sociais e levá-los à reflexão de proposições para os problemas de suas dadas realidades.

Alentejano e Rocha-Leão (2006) afirmam que o trabalho de campo deve ser mediado pelo docente com um planejamento prévio, com roteiros para promover uma interpretação significativa de dada realidade, por meio da observação dos fenômenos, para, assim, contribuir com a formação cidadã dos estudantes. Salientamos alguns elementos caros ao trabalho de campo

[...] como um momento de integração entre fenômenos sociais e naturais que se entrecruzam na realidade do campo [...] cabe destacar que tanto na realidade do campo quanto na teoria os aspectos sociais e naturais são indissociáveis [...] quando se pretende ensinar Geografia, não se deve fragmentar a realidade, e esses aspectos devem se associar aos aspectos sociais na explicação da realidade. (ALENTEJANO; ROCHA-LEÃO, 2006, p. 63, grifo nosso).

\footnotetext{
34 “"...] não somente investigar o território, mas também as relações interpessoais em tarefas coletivas. Um meio local onde encontramos problemas semelhantes que os permite relacionar certos fenômenos em uma escala global" (tradução nossa).
} 
Nesse sentido, alinhamo-nos à concepção de trabalho de campo como instrumento didático a serviço da teoria social crítica da Geografia no âmbito exploratório, voltado para a transformação da realidade, e um meio para desvendar os mecanismos de construção da dominação e da exploração (ALENTEJANO; ROCHA-LEÃO, 2006). Para expor melhor a concepção de trabalho de campo que admitimos e nos alinhamos, elaboramos o esquema a seguir.

Figura 2 - Síntese da concepção de trabalho de campo

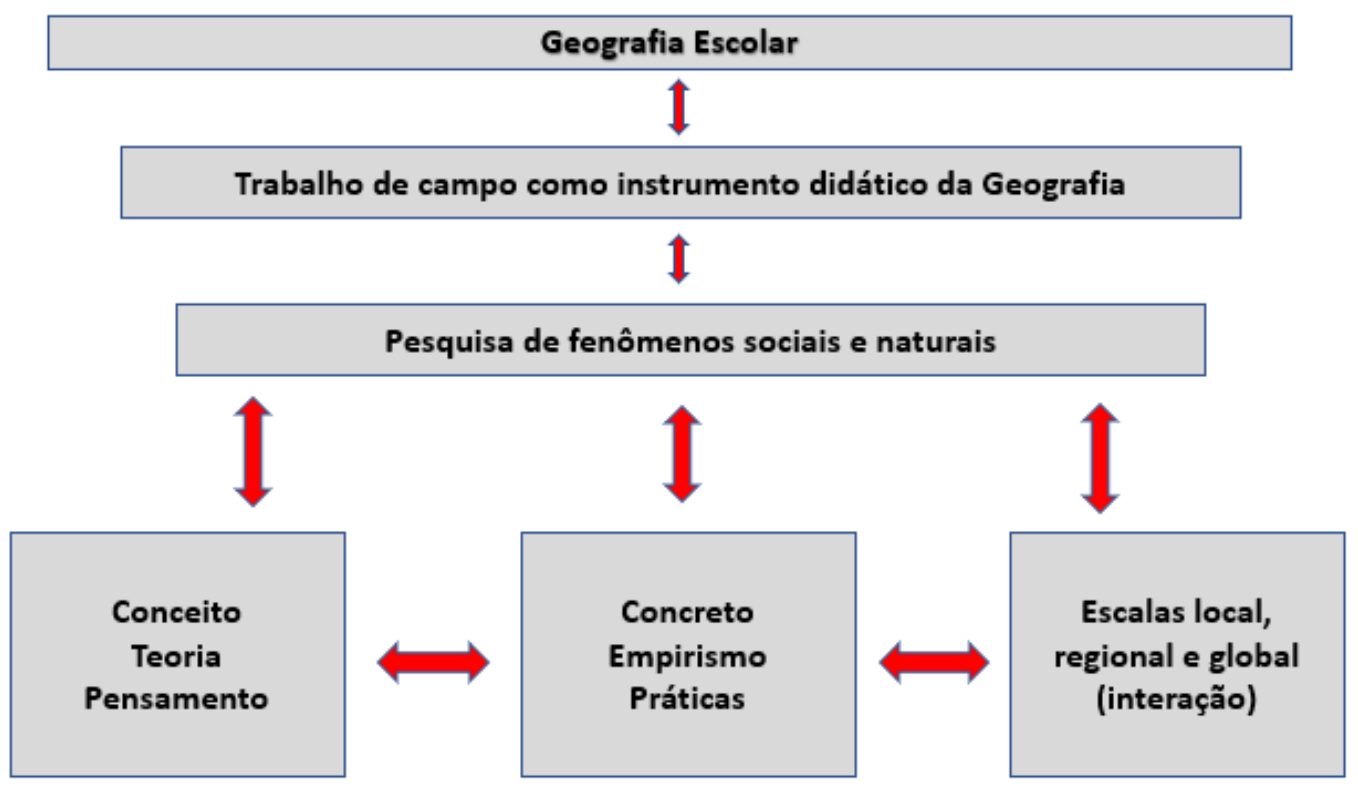

Fonte: elaborado pelo autor

Com base nos autores referenciados anteriormente sistematizamos a figura 2. Esta figura é pautada nas contribuições teóricas apresentadas nesta subseção e sustentadas por estudos científicos que comprovam a valorização do trabalho de campo para um ensino de Geografia. No esquema (Figura 2), salientamos nossa concepção de trabalho de campo como instrumento da Geografia Crítica, voltado à Geografia Escolar. Nesta concepção entendemos a importância do empírico e do teórico para, em diferentes escalas, compor a leitura e análise do espaço geográfico.

Desta forma, nosso entendimento sobre o trabalho de campo se afasta da ideia, ainda presente, de banalização ${ }^{35}$ do trabalho de campo no ensino de Geografia e, com isso, “[...] pressupõe, sobretudo, avançar em duas direções: a articulação teoria-prática; o olhar crítico sobre a realidade associado à ação transformadora" (ALENTEJANO; ROCHA-LEÃO, 2006, p. 64).

35 Entendemos como realização de práticas descontextualizadas, com ausência de planejamento ou mesmo despregadas do currículo. Práticas que não promovem a aprendizagem significativa, no caso, no ensino de Geografia. 
Essa leitura pode ser feita correlacionando todos os elementos do espaço geográfico, construído por meio da "[...] unicidade técnica, a convergência dos momentos e a unicidade do motor" (SANTOS, 2017, p.123) em um espaço influente sobre as ações humanas, sejam eles discutidos na Geografia Escolar como conteúdo da Geografia física e ou da Geografia humana, por mediação do professor em um fluxo constante de idas e vindas.

O manual do projeto Nós Propomos! aborda de modo explícito o trabalho de campo ${ }^{36}$ como um componente das etapas do projeto, sendo descrito no manual no $7^{\circ}$ passo. Segundo o manual, o trabalho de campo visa a estimular as "[...] constatações necessárias acerca do problema objeto do estudo, além de que poderá também realizar entrevistas à comunidade e outras técnicas que entender que enriquecerão a sua proposta de trabalho" (BAZOLLI; COSTA E SILVA; VIANA., 2017, p. 31).

Desta forma, salientamos que o manual do referido projeto se alinha à teoria no sentido de pensar que o "[...] trabalho de campo deve marcar uma educação geográfica comprometida com a participação cidadã" (CLAUDINO, 2018, p. 299). Nessa ação de campo, os alunos

[...] vêm para a rua, fotografam os espaços ou equipamentos sobre que querem atuar e escutam as populações, em pequenos inquéritos ou entrevistas. Quando os alunos identificam um problema, muitas vezes constroem/idealizam propostas de solução para o mesmo. Valoriza-se as suas opiniões, mas pretende-se que escutem a população sobre estes problemas e sobre as suas próprias propostas, sublinhando-se que a recolha destas opiniões dá mais solidez e credibilidade às suas propostas. (CLAUDINO, 2018, p. 282).

A partir das indicações do referido autor, compreendemos ser por meio do trabalho de campo que os alunos observam e analisam o espaço geográfico para posterior proposição de soluções para os problemas locais e a ressignificação do saber escolar debatido em sala de aula.

A etapa que contém a ação de trabalho de campo é representada no manual por meio de uma pessoa gigante "atuando" como investigador com uma lupa na comunidade (figura 3), dada a riqueza dessa ação para a apreensão de novos conhecimentos e para a formação cidadã dos estudantes.

$\overline{36}$ No Manual do projeto, trabalho de campo é entendido como visita de campo. 
Figura 3 - Representação da $7^{\circ}$ etapa do "Projeto Nós Propomos! cidadania e inovação na educação geográfica", intitulada "Trabalho de campo e outras técnicas de pesquisa"

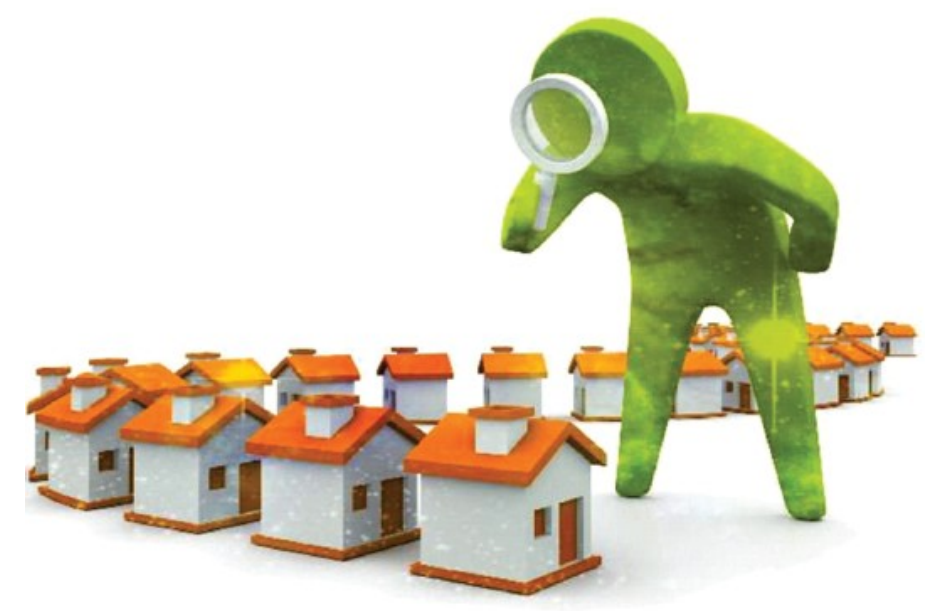

Fonte: (BAZOLLI; COSTA E SILVA; VIANA, 2017, p. 31)

\subsection{O estudo do meio}

Entendido como o próprio espaço geográfico, numa ampla relação de elementos da natureza com o ser humano e a sociedade, o conceito de meio compreende o vivido, o percebido, o sensível das relações cotidianas.

Para Nidelcoff (1979, p. 10), o conceito "meio" pode ser entendido como

[...] é toda aquela realidade física, biológica, humana que rodeia os alunos, estando ligados a ele de uma maneira direta, através da experiência e com a qual estavam em intercâmbio permanente. Não se pode, portanto, precisar os limites do meio, porque à medida que a criança cresce seus relacionamentos com a realidade que a rodeia se tornam imperiosos. O meio é cada vez mais amplo, se estende: meu quintal, minha rua, meu bairro, meu lugarejo, os arredores do meu lugarejo.

Admitimos que o trabalho de campo é componente indispensável para o estudo do meio e, desta forma, tem seus critérios referentes às pesquisas e ao trabalho dos geógrafos em que "[...] conceitos, teorias e procedimentos metodológicos devem construir uma unidade orgânica e coerente no desenvolvimento dos trabalhos de pesquisa e de campo" (SERPA, 2006, p. 21). Nesse sentido, o estudo do meio não é uma ação "nova" no campo da Geografia e do ensino de Geografia, como afirma Lopes e Pontuschka (2009, p. 176)

O Estudo do Meio não é uma prática pedagógica nova no universo educacional brasileiro. Faz parte, na verdade, de uma 'tradição escolar' que, inspirada em educadores tais como Francisco Ferrer e Guardia (1859-1909) e Célestin Freinet (1896-1966), tem por objetivo proporcionar aos estudantes 
uma aprendizagem 'mais perto da vida', ou seja, um contato mais direto com a realidade estudada, seja ela, natural ou social.

Muitos intelectuais já se debruçaram sobre o tema como forma de proporcionar um Ensino não tradicional nas escolas e para os alunos de forma geral. Neste sentido, alguns autores o estudo do meio pode ser desenvolvido por meio de um processo que envolve, também, as saídas da sala de aula. Tais saídas apresentam diferentes termos e concepções no ensino de geografia.

Nesse sentido, alguns autores o fato do estudo do meio "[...] ser o resultado do trabalho de inúmeros educadores que, ao longo de várias décadas, se dedicaram a construir práticas de ensino que possibilitassem uma melhor compreensão do mundo e a superação dos desafios sócio-educacionais que se lhes apresentavam à época". (GOETTEMS, 2006, p. 52 apud LOPES; PONTUSCHKA, 2009, p. 176)

No ensino de Geografia, o estudo do meio é valorizado por vários investigadores que se dedicaram ao tema. Thralls (1967) concebe as aulas de campo como excursões na comunidade local para melhorar a compreensão da Geografia. Em contrapartida, a ideia de excursão geográfica é problematizada no estudo de Sansolo (2000), que argumenta sobre a passividade do aluno ter as informações controladas previamente pelo professor, tornando-a uma atividade meramente ilustrativa.

Assim, “[...] esta modalidade carrega em si uma conotação ilustrativa do conhecimento, assim como mapas e livros didáticos que simplesmente ilustram o conhecimento depositado pelo professor" (SANSOLO, 2000, p. 137). Neste sentido, a excursão geográfica torna-se "mecanizada" e um reprodutor de um ensino tradicional. Ambos os autores citados, discutem a relevância que a saída da sala de aula pode contribuir com a formação dos alunos.

Monteiro e Oliveira (1988) intencionaram tirar os alunos dos "muros da escola" e propor atividades de observação constante no externo, chamadas de visitas de campo. Tais visitas têm a função de "[...] proporcionar aos alunos diferentes hábitos e atitudes de comportamentos em diferentes ambientes, oferecendo as possibilidades de descobrimento de novos valores e novas relações, enriquecendo e ampliando suas experiências" (MONTEIRO; OLIVEIRA, 1988 apud OLIVEIRA; ASSIS, 2009, p. 201).

No estudo de Oliveira e Assis (2009, p. 203), o estudo do meio é entendido como turismo geoeducativo que traz a “[...] incorporação de saberes espaciais não científicos, 
densos de significados cultural e ambiental [...]". Ele permite, ao estudante, a interação com lugares reais do cotidiano vivido, tanto atrativos quanto repulsivos.

A explicitação dos termos apresentados são importantes, pois auxiliam a construir o conhecimento sobre as possibilidades de práticas não tradicionais de ensino, no sentido de promover um ensino de Geografia que esclareça a importância da apropriação do espaço na vida social dos alunos.

Isto posto, concebemos o estudo do meio como um método de ensino (PONTUSCHKA, 2004; LOPES; PONTUSCHKA, 2009, 2010; ZABALA, 2007) que envolve várias fases de desenvolvimento, sendo o trabalho de campo uma delas.

Dentre os autores brasileiros que publicaram sobre estudo do meio, optamos por nos alinhar com a definição e orientação metodológica definida pela Prof. ${ }^{a}$ Dr. ${ }^{a}$ Nídia Nacib Pontuschka (2004, 2013) e do Prof. Dr. Claudivan S. Lopes (2009; 2010). Nossa escolha está pautada nas bases epistemológicas que tais autores expõem. A nossa concepção de estudo do meio está alinhada com os seguintes eixos norteadores: interdisciplinaridade, dialogicidade e formação científica para a cidadania.

A interdisciplinaridade que o estudo do meio envolve nos trabalhos dos professores explicita uma complexidade de leitura da realidade a ser feita em várias etapas, objetivando despertar a curiosidade sobre a paisagem, detectar os problemas nela existentes e estabelecer a relação entre os fatos verificados e o cotidiano dos alunos (PONTUSCHKA, 2004).

Podemos admitir o real entrelaçamento entre as disciplinas de História e de Geografia num estudo do meio. A ação interdisciplinar para a apreensão de dada realidade possibilita o desenvolvimento de conhecimentos (OLIVEIRA; ASSIS, 2009; LACOSTE, 2006). Neste sentido, é relevante o entendimento do tempo como componente fundamental para os alunos investigarem, de forma crítica e analítica, dada realidade local.

O estudo do meio possibilita atingir um dos aspectos fundamentais: o estudo do tempo, permitindo uma ruptura com o ensino calcado na linearidade do tempo positivista, progressista. Esse método baseia-se em uma problematização situada no presente, diante de um determinado espaço dimensionado em seus diversos níveis: social, político, econômico e cultural. A problematização define o período a ser estudado juntamente com a coleta das fontes possíveis a serem investigadas na identificação dos problemas, define-se a problemática a ser pesquisada. O tema apreendido pela observação de uma dada realidade não se limita a um tempo homogêneo e contínuo, mas é abordado pelas mudanças e permanências, pelas diferenças e semelhanças entre passado e presente, entre o espaço vivenciado e outros espaços (SÃO PAULO-SME, 1992, p. 35). 
Salientamos que o tempo é componente importante para o aluno. Ele deve permear as ações de: observação e problematização. Para além disso, destacamos que o estudo do meio constitui um processo amplo de sistematização de informações em conhecimentos (PONTUSCHKA; PAGANELLI; CACETE, 2009, p. 175-180, grifo dos autores), a saber:

O encontro dos sujeitos. Esse é o momento da mobilização da escola, quando há uma proposta dos sujeitos sociais de efetuar uma pesquisa, tendo em vista a aproximação das respectivas áreas do conhecimento e a melhoria da formação do aluno [...].

Visita preliminar e opção pelo percurso. Escolher os meios a estudar é optar pelo currículo que quer desenvolver. [...]. Alguns fatores necessitam ser pensados: o tempo decorrente de uma saída até o lugar da pesquisa de campo; qual dos bairros visitados contém elementos expressivos que contemplam melhor os objetivos de todas as disciplinas envolvidas[...].

Planejamento. [...] É preciso lembrar que isso não garante que todas as atividades previstas sejam efetivadas, pois em um trabalho de campo ocorrem imprevistos [...]

Elaboração de caderno de campo. Na elaboração do caderno de pesquisa de campo, é importante haver o levantamento dos instrumentos necessários, das práticas de coleta de informação, dos diferentes registros - entrevistas, desenhos, lugares - a ser fotografados [...]

A pesquisa de campo reveladora da vida. [...] É necessário sair a campo sem julgamentos ou preconceitos: libertar o olhar, o cheirar, o ouvir, o tatear, o degustar. [...] As falas podem ser carregadas [...] tudo isso vai mostrando a cidade com seus ritmos, suas marcas no tempo e no espaço [...].

Desse modo, o planejamento e a execução do estudo do meio podem ser feitos por meio de um processo pedagógico no qual se apresentam práticas que envolvem a da saída da Escola. Sobre isso, a referida autora coloca que

Uma das etapas importantes do estudo do meio é o trabalho de campo a saída da escola já permite outro modo de olhar. $O$ aluno pode, se bem orientado, utilizar todos os seus sentidos para conhecer melhor certo meio, usar todos os recursos de observação e registros e cortejar as falas das pessoas de diferentes idades e profissões. (PONTUSCHKA, 2009, p. 174, grifo nosso).

Os alunos participantes podem sair a campo, pesquisar, debater e dialogar na localidade de forma democrática e cidadã. Eles vivenciam a realidade e a complexidade do meio, de forma científica e planejada, pelo docente. Além disso, existe a sistematização dos dados coletados em campo e seu tratamento pelos alunos e pelos professores e a avaliação de todo o processo realizado (LOPES; PONTUSCHKA, 2010).

O trabalho de campo pode permitir o contato real com o meio em que o aluno vive. Desta forma, ele pode reconhecer os seus símbolos e códigos de conduta e de circulação 
cultural. Pode se apropriar de forma científica dos fatos e entendê-los de forma sistemática, com o auxílio da dialogicidade, com o docente (PONTUSCHKA, 2004).

Os Parâmetros Curriculares Nacionais - PCNs - de Geografia e de História destacam a importância e o que vem a ser o estudo do meio para os dois referidos componentes curriculares. A relevância da sua aplicabilidade no espaço escolar é destacada como uma solução possível para sair do "[...] discurso descritivo tão enfadonho e pouco argumentativo, que tem tornado a Geografia uma das áreas menos atraentes para os jovens, e contraditoriamente mais fascinantes na vida das pessoas." (BRASIL, 1998, p. 91). Para isto, é preciso encará-lo na sua complexidade.

O estudo do meio não se relaciona à simples obtenção de informações fora da sala de aula ou à simples constatação de conhecimentos já elaborados, encontrados em livros didáticos, enciclopédias ou jornais, que se pode verificar in loco na paisagem humana ou geográfica. Não se realiza um estudo do meio para se verificar que as casas construídas no início do século seguem uma série de características relacionadas ao estilo neoclássico. E não se visita uma fábrica para simplesmente verificar, por exemplo, que existe uma divisão de trabalho entre os operários (BRASIL, 1998, p. 89).

Os PCNs citam o estudo do meio como metodologia de pesquisa interdisciplinar, recurso didático ou recurso pedagógico e demonstram como pensá-lo de forma prática no cotidiano escolar para “[...] um modo de aproximar a teoria escolar da observação direta" (BRASIL, 1998, p. 93).

Desta forma, entendemos que os PCNs contribuem com as reflexões sobre o estudo do meio na complexidade existente entre currículo escolar e a apropriação, de fato, do conhecimento geográfico pelo estudante.

Destacamos, no entanto, que a BNCC não menciona em nenhum momento, o termo "estudo do meio" em suas páginas. Menciona o termo "trabalho de campo" em apenas dois momentos, que apresentamos a seguir:

No Ensino Fundamental - Anos Iniciais, é importante valorizar e problematizar as vivências e experiências individuais e familiares trazidas pelos alunos, por meio do lúdico, de trocas, da escuta e de falas sensíveis, nos diversos ambientes educativos (bibliotecas, pátio, praças, parques, museus, arquivos, entre outros). Essa abordagem privilegia o trabalho de campo, as entrevistas, a observação, o desenvolvimento de análises e de argumentações, de modo a potencializar descobertas e estimular o pensamento criativo e crítico. (BRASIL, 2017, p. 355).

Esse processo de aprendizado abre caminhos para práticas de estudo provocadoras e desafiadoras, em situações que estimulem a curiosidade, a reflexão e o protagonismo. Pautadas na observação, nas experiências diretas, 
no desenvolvimento de variadas formas de expressão, registro e problematização, essas práticas envolvem, especialmente, o trabalho de campo. (BRASIL, 2017, p. 369).

Este termo é explicitado em Geografia nos anos iniciais do Ensino Fundamental, e "silenciado" na continuação do documento, ou seja, não é citado nos anos finais do Ensino Fundamental e tão pouco é mencionado no Ensino Médio.

Podemos notar que, no estudo do meio, o docente é o mediador no processo de construção e reconstrução do currículo de um projeto educativo que pressupõe autonomia e valorização intelectual do discente (PONTUSCHKA; PAGANELLI; CACETE, 2009), e que busca promover uma aprendizagem significativa e uma real apreensão do espaço percebido e vivido.

Importante destacar que o estudo do meio abarca a ideia de "dialogicidade" de Paulo Freire, presente no documento oficial da Secretaria Municipal de Educação de São Paulo SME (1991), referido por Pontuschka (2013). A “dialogicidade" constitui-se pela constante construção com as experiências e saberes docentes e

[...] uma metodologia que tenha o diálogo como sua essência, e que peça ao educador uma postura crítica, de problematização constante, de distanciamento, de estar na ação; uma metodologia de trabalho que expõe na direção da participação, na discussão do coletivo e que, por isso, exija uma certa disponibilidade de cada educador. (SÃO PAULO, SME, 1991 apud PONTUSCHKA, 2013, p. 192).

Destacamos essa ideia para pensar o estudo do meio no ensino de Geografia, pois consideramos relevante que o docente também esteja em formação constante e em diálogo com seus alunos e com o espaço geográfico que os cercam. A "dialogicidade" exige permanente colaboração entre os vários sujeitos sociais, “[...] um trabalho solitário para um coletivo, orientado para o interdisciplinar" (PONTUSCHKA, 2013, p. 192).

O uso do estudo do meio possibilita discutir não somente a Geografia e o espaço, mas também questões sociais, culturais e econômicas em diferentes modalidades do vivido e compartilhado, além de despertar a curiosidade dos membros da comunidade escolar (FREIRE, 2014). O diálogo entre o professor, os alunos e o meio estudado devem ser constantes. Para Lopes e Pontuschka (2009, p. 178):

Os Estudos do Meio podem fortalecer, para além de sua dimensão estatal, a dimensão pública da educação. Trata-se da organização de fóruns de discussão para os problemas vividos coletivamente pela comunidade onde a escola está inserida. Ao desvelar as injustiças sociais e outras questões que afetam o bem-estar de uma determinada comunidade escolar. 
Por meio do ensino de Geografia é possível desenvolver sequências de atividades que promovam o protagonismo juvenil e o estudo da localidade. Assim, a capacidade de observação, do mais simples ao mais complexo, pode ser estimulada no espaço geográfíco (BOSCOLO, 2007). O estudo do meio possui caráter de cientificidade ao propor pesquisa e análise do meio. Pontuschka (2004, p. 262, grifo nosso) afirma que

O estudo do meio apropria-se da investigação do historiador e do geógrafo, ao iniciar com uma leitura geral do espaço a ser estudado, problematizandoo. Levanta as fontes para estudo e inicia a preparação para uma leitura crítica, elaborando um processo de interpretação dos documentos históricos, geográficos, biológicos ou de outras naturezas. O princípio básico desse processo reside na convicção de que um material de estudo só tem valor para quem sabe interrogá-lo e interpretá-lo à luz de conhecimentos anteriores.

Portanto, o estudo do meio caracteriza um método de investigação feito no espaço geográfico. Essa investigação é pautada nos conhecimentos científicos e escolares promovidos nas aulas e com as saídas da sala de aula para analisar as contradições sociais e problematizar os fatos obtidos. Neste sentido, o estudo de Pereira (2017, p. 112) aponta as contribuições do ensino de Geografia para a resolução de problemas urbanos. Essa resolução está ligada à cidadania, "[...] enquanto pilar estruturante de uma sociedade consciente e participante, encontra-se em estreita articulação com a dimensão cidadã do território".

Para tanto, admitimos que o estudo do meio permite as investigações nesses territórios, a problematização dos eventos, a tomada de consciência dos alunos e, com isso, a possibilidade de tomada de decisões locais, para o despertar da existência de cidadãos civicamente ativos, participativos e conscientes na sociedade atual (PEREIRA, 2017). 
Figura 4 - Sistematização do estudo do meio

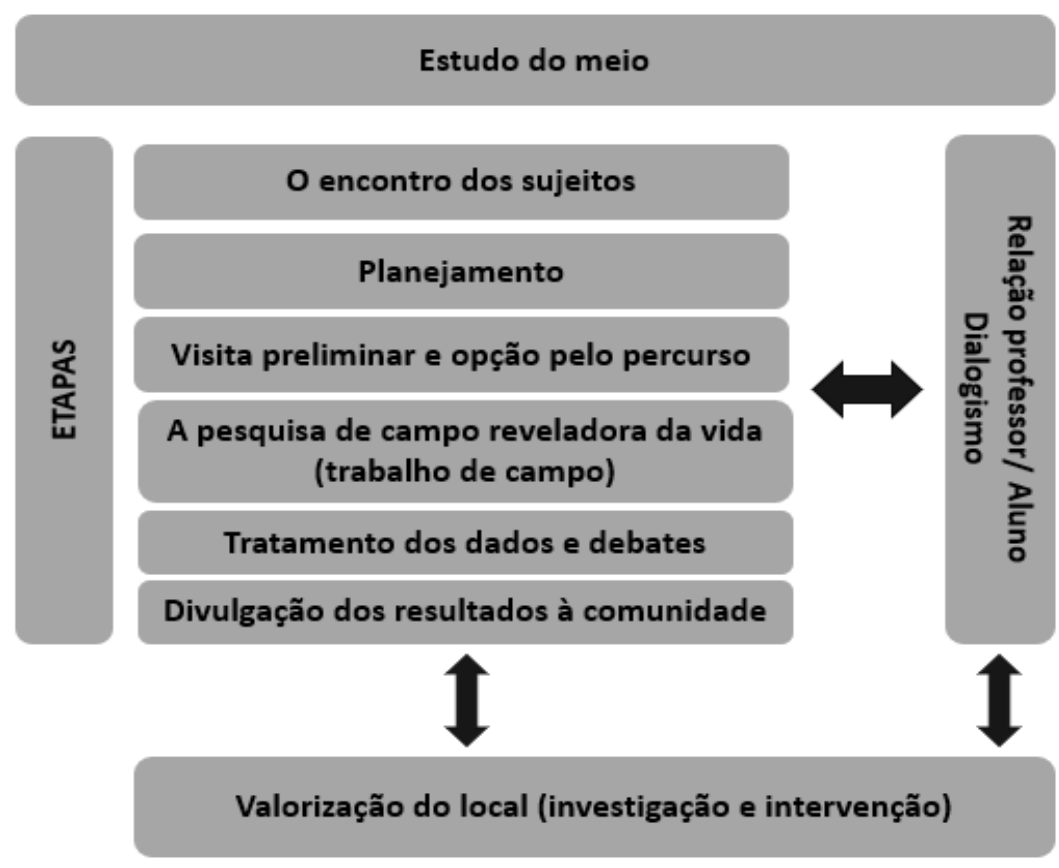

Fonte: elaborado pelo autor

Observamos na figura 4 que o estudo do meio é composto por etapas (PONTUSCHKA; PAGANELLI; CACETE, 2009, p. 175-180), as quais se relacionam nitidamente com a valorização do local, por meio da investigação e de intervenção no mesmo por meio do trabalho de campo. Todo o processo é permeado pela ação conjunta entre o professor e os alunos, em um diálogo constante (FREIRE, 2014).

Destacamos que o estudo do meio não pode ser banalizado e usado de forma indiscriminada para denominar qualquer ação desenvolvida fora da sala de aula, pois "[...] embora possuem seu valor pedagógico e lúdico, não corresponde exatamente ao estudo do meio" (LOPES; PONTUSCHKA, 2010, p. 38). Isto posto, salientamos que existe um rigor metodológico no estudo do meio, sendo que ele deve responder às necessidades sociais e institucionais e promover uma contínua reflexão crítica sobre as razões de sua prática (PONTUSCHKA, 2004).

Destacamos a construção de uma tríade de valores: a construção de si, do outro e da sociedade ao ver e analisar o espaço geográfico. Essa construção reforça o caráter científico e investigativo do estudo do meio. Neste sentido, Castellar (2005, p. 105) afirma que

No espaço geográfico encontramos objetos técnicos, transformados ou não, nele há relações simbólicas e afetivas, que revelam as tradições e costumes, indo além da relação ser humano-natureza. Neste contexto, ao observar os elementos que compõem o espaço vivido, o aluno perceberá a dinâmica das relações sociais presentes na organização e na produção desse espaço, bem 
como o significado do processo de produção de sua identidade individual e coletiva.

Essa postura científica e investigativa pode garantir o hábito democrático na medida em que as observações e sistematização do saber geradas a partir do estudo do meio podem desenvolver novos modos de ver e agir. Zabala (2007) cita o estudo de Ciari (1980), no qual admite

A capacidade de propor hipóteses, de programar uma experiência, de tirar conclusões ensina a criança a pensar, a raciocinar, a comprovar se uma coisa é verdadeira ou falsa, ensina a distinguir e a escolher. Uma mente passiva, inerte, conformista, não pode constituir uma personalidade democrática (CIARI, 1980 apud ZABALA, 2007, p. 165).

A partir do que discorremos, destacamos a ampla relação entre a realização de trabalho de campo no ensino de Geografia e uma educação geográfica para a cidadania e socialmente útil (SOUTO GONZÁLEZ, 1998). Essa cidadania é desenvolvida no aluno na medida em que ele conhece a sua localidade e sabe agir nela de modo mais crítico. Neste sentido, Souto González e Claudino (2019, p. 9, grifo nosso) admitem que a metodologia do projeto Nós Propomos!

[...] é a análise geográfica por meio de 'trabalho de campo', ou investigação 'in situ', que favorecem o processo de ensino-aprendizagem das Ciências Sociais em aula e fora dela. O desenvolvimento do projeto gera uma Aprendizagem Baseada em Projetos (ABP), e, ao mesmo tempo, promove uma Aprendizagem em Serviço (APS), que responde às necessidades reais da sociedade.

Destacamos que os detalhamentos do desenvolvimento do projeto, elencados em etapas, como destaca Bazolli, Costa e Silva e Viana. (2017), trazem uma metodologia que tem como base o trabalho de campo e as aprendizagens baseadas em projetos (para os alunos) e em serviço (para o professor). Assim, o projeto pode responder à necessidade da sociedade por investigações de problemas socioambientais locais com maior participação social e cidadania ativa, em consonância com o método do estudo do meio (LOPES; PONTUSCHKA, 2009, 2010; PONTUSCHKA, 2014; PONTUSCHKA; PAGANELLI; CACETE, 2009).

Por conseguinte, o projeto Nós Propomos! pode desenvolver o estudo do meio para a promoção da educação geográfica, sendo vista nas práticas pedagógicas de professores participantes no estado de São Paulo, no Brasil. 


\title{
4 METODOLOGIA DE PESQUISA
}

\author{
Para que a relação de pesquisa se modifique pouco a pouco, é \\ preciso que na universidade a grande maioria dos jovens seja \\ iniciada na pesquisa e no trabalho de campo, a fim de que \\ possa, em seguida, qualquer que seja seu futuro profissional, \\ explicar às pessoas porque é preciso ver as pesquisas, porque é \\ para eles preciso conhecer seus resultados e como estes podem, \\ em seguida, ser utilizados. (LACOSTE, 2006, p. 87).
}

Nesta seção, apresentamos a pergunta de pesquisa, os objetivos propostos para o desenvolvimento desta investigação, a abordagem e os procedimentos metodológicos, assim como sua descrição. Além disso, trazemos apontamentos sobre o que entendemos ser fundamental nesta investigação quanto aos cinco professores participantes.

Após a elaboração do projeto de pesquisa e do cronograma de trabalho científico, realizamos outras etapas significativas para a construção da escrita aqui apresentada, como:

1. A delimitação dos professores participantes e seu contato para apresentação da investigação;

2. Levantamento bibliográfico;

3. Submissão do projeto ao Comitê de Ética em Pesquisa (CEP) da Faculdade de Filosofia, Ciências e Letras de Ribeirão Preto (FFCLRP/USP) (ANEXO A);

4. Coleta de dados por meio das entrevistas (APÊNCIDE A), após a aprovação da CEP;

5. Escrita do texto acadêmico.

O trabalho desenvolvido seguiu os preceitos de um estudo qualitativo, por meio, dentre outros aspectos, de um levantamento bibliográfico. Este, segundo Gil (2007, p. 5), “[...] é desenvolvido a partir de materiais elaborados, constituídos por livros e artigos científicos".

Diante do exposto, o objetivo central do presente trabalho é levantar e caracterizar as práticas pedagógicas dos professores participantes no "Projeto Nós Propomos! cidadania e inovação na educação geográfica" no estado de São Paulo, no

Brasil. Diante do referido objetivo, delimitamos os objetivos específicos, a saber:

a) Descrever a sistemática do trabalho docente realizado;

b) Analisar, sob a ótica dos participantes, os impactos que tais práticas pedagógicas proporcionaram aos professores e aos alunos envolvidos; 
c) Refletir sobre os desafios e os avanços do projeto tendo em vista o ensino de Geografia e a formação cidadã no Brasil.

\section{Nossa questão central é: como se configuram as práticas pedagógicas dos professores participantes do projeto “Nós Propomos!", no estado de São Paulo, no}

Brasil? Diante de tais objetivos, destacamos nossa vontade de estudar um projeto que busca romper com práticas pedagógicas tradicionais no ensino de Geografia. Como professores, sempre nos incomodou a ideia de uma escola reprodutivista (SPOSITO, 2003) e há anos buscávamos desenvolver uma trajetória formativa que nos propiciasse leituras e práticas diferenciadas ${ }^{37}$.

Desta forma, concordamos com Azanha (1992, p. 11) quando afirma que "[...] a preparação para uma pesquisa em Educação tem mais a ver com a solidez da própria formação pedagógica do que com eventuais cursos sobre metodologias”. Esta investigação carrega uma subjetividade de pesquisa e da vivência dos pesquisadores ao elencar as práticas pedagógicas de professores atuantes no estado de São Paulo, no Brasil, participantes do "Projeto Nós Propomos! cidadania e inovação na educação geográfica".

Isto posto, podemos perceber como a subjetividade e a legitimação são pontos marcantes na pesquisa em Educação, assim como levar em conta os consensos estabelecidos pela comunidade acadêmica a fim de validar a investigação que é desenvolvida. Segundo Brito e Leonardos (2001, p. 10),

De forma geral, todos os processos de pesquisa, ainda que reivindiquem uma identidade própria, devem justificar as razões que os conduzem a adotar tais procedimentos. Se as justificativas avançadas forem convincentes e chegarem a persuadir a comunidade científica, poder-se-á, desse modo, reconhecer e legitimar uma nova linha de pesquisa.

Nessa complexa relação, o pesquisador pode negociar, e de fato negocia, a todo instante, com a sua própria subjetividade, para deixar a sua "voz" na escrita da investigação, sem comprometer a ética e os consensos da academia, a fim de promover relevantes contribuições na área educacional.

O pesquisador detém o poder de fala na sua escrita por meio de sua subjetividade. Esta foi negada, por muito tempo, nas pesquisas em Educação e emergiu como fator preponderante há poucos anos. Corroboram com a ideia Brito e Leonardos (2001, p. 19), ao dizerem que

\footnotetext{
37 Destacamos nossa participação em dois eventos científicos ao longo da realização da pós-graduação em Educação. O primeiro foi o I Colóquio Internacional Enseñansa de la Geografía de las Ciencias Sociales, realizado em março de 2019, em Bogotá, na Colômbia. O segundo foi o Encontro Nacional de Práticas e Ensino de Geografia, em julho de 2019, em Campinas-SP, no Brasil.
} 
O reconhecimento da subjetividade do pesquisador como pessoa humana historicamente situada, dotada de atributos e interesses provenientes da sua posição de classe, etnia, idade e orientação sexual foi na verdade, uma preciosa contribuição no sentido de maior objetividade no processo de pesquisa.

Não podemos deixar de salientar que o foco de pesquisa da presente investigação parte de indagações pessoais sobre uma Educação emancipadora e voltada para a cidadania. Para contextualizar tal conceito, optamos por apresentar documentos legais internacionais ${ }^{38}$ e nacionais $^{39}$ que abordam nossa temática de forma explicita e são marcos legais para o desenvolvimento da Educação.

Tal aspecto foi necessário para entendermos o que os citados documentos sinalizam sobre a cidadania e por serem referência no trabalho escolar. Desta forma, tais documentos dão amparo tanto para nossa investigação, quanto para o projeto Nós Propomos!.

Martins (2004) destaca que os cientistas sociais tomam como objeto de investigação grupos sociais que têm alguma identificação política. Nesta investigação, a aproximação circunscreve-se em investigar um projeto de ensino ibero-americano que busca colocar o jovem como protagonista de sua realidade a fim de que possa exercer sua cidadania e obter aprendizagem significativa.

Buscamos desvelar práticas pedagógicas que são realizadas em espaços escolares e não escolares. Temos a ideia de que "[...] a Escola ainda constitui campo importante de reflexão sociológica sobre a Educação, desde que incorporado no quadro de uma maior complexidade das relações entre as agências socializadoras" (SPOSITO, 2003, p. 212).

Analisamos as práticas pedagógicas promovidas pelos cinco docentes participantes do projeto no estado de São Paulo, Brasil. Parte dessas ações ocorre dentro da escola e parte no seu exterior, por meio do trabalho de campo, etapa importante priorizada no projeto investigado.

Estudar as práticas dos cinco docentes participantes do "Projeto Nós Propomos! cidadania e inovação na educação geográfica" é admitir que os alunos são sujeitos ativos no processo de aprendizagem e apresentam "bagagem cultural" e conhecimentos prévios significativos.

\footnotetext{
38 Para esta investigação selecionamos os seguintes documentos internacionais: A carta internacional da Educação geográfica e o Comunicado da Comissão da Comunidade Europeia.

39 Para esta investigação selecionamos os seguintes documentos nacionais: Constituição Federal, Lei de Diretrizes e Bases, Parâmetros Nacionais Curriculares e a Base Nacional Comum Curricular.
} 


\subsection{A abordagem qualitativa}

Nesta investigação optamos por uma abordagem qualitativa por entender que ela é a que melhor responde aos nossos propósitos. Esse tipo de pesquisa tem em seu desenvolvimento o "[...] caráter descritivo, o ambiente natural como fonte de dados e o pesquisador como fonte natural, o significado que as pessoas dão às coisas e à sua vida como preocupação do investigador [...]" (NEVES, 1996, p. 76). A descrição dos fenômenos estudados leva o pesquisador à imersão do fato, e o uso da sua subjetividade está presente na recolha dos dados e na sua divulgação (BOGDAN; BIKLEN, 1994).

Houve uma interação social entre a escrita científica, a seleção do material para leitura, o trabalho de coleta de dados e o tratamento dado no gabinete para a escrita desta investigação. Portanto, o meio natural entrelaça-se com o pesquisador a todo momento e disso é estabelecido um arcabouço de experiências para a investigação.

Uma característica dessa abordagem refere-se ao fato de que os "[...] investigadores qualitativos interessam-se mais pelo processo do que simplesmente pelos resultados ou produtos" (BOGDAN; BIKLEN, 1994, p. 136). O processo é visto como o caminhar da pesquisa, desde a elaboração do projeto até a apresentação dos resultados na defesa da investigação. Segundo Lakatos e Marconi (2010, p. 166), temos que a pesquisa bibliográfica tem como finalidade colocar

[...] o pesquisador em contato direto com tudo o que foi escrito, dito ou filmado sobre determinado assunto, inclusive conferências seguidas de debates que tenham sido transcritas por alguma forma quer publicadas, quer gravadas. Desta forma, a pesquisa bibliográfica, não é mera repetição do que foi dito ou escrito sobre o assunto, mas propicia o exame de um tema sob novo enfoque ou abordagem, chegando a conclusões inovadoras.

Neste sentido, concordamos com os autores quando destacam a necessidade de termos o "contato com tudo o que foi produzido pelo assunto". No caso do projeto investigado, as produções acadêmicas estão sendo construídas em diferentes localidades brasileiras e em diversos países ibero-americanos, em distintas universidades e grupos de pesquisa. No caso desta investigação, temos um recorte específico sobre as práticas pedagógicas promovidas por professores ligados ao projeto no estado de São Paulo.

Durante o levantamento bibliográfico, procuramos referências em artigos, anais de eventos nacionais e internacionais, assim como dissertações e teses produzidas no Brasil, na Espanha e em Portugal, para nos proporcionar um maior embasamento teórico. 
Convidamos os cinco professores participantes do referido projeto para colaborar conosco nesta investigação e todos aceitaram. São eles: a professora Valquíria, de IbitingaSP, o professor Gabriel, de Marília-SP ${ }^{40}$, a professora Sonara, de Serrana-SP, a professora Rosani e o professor Américo, ambos de Mococa-SP. Os primeiros nomes dos participantes foram mantidos, com consentimento de todos.

Para além disso, esta investigação tem como foco apresentar as contribuições do projeto para o ensino de Geografia e destacar as práticas pedagógicas desses professores participantes como indícios da contribuição do projeto na educação geográfica para a cidadania.

Na realização desta investigação, separamos os professores em dois grupos para fazer as análises, pois atuam em esferas diferentes e as abordagens do projeto são distintas na Educação Básica e na Superior. Desta forma, podemos deixar visível os diferentes lugares de fala dos participantes, no sentido de valorizá-los em uma dimensão profissional e humana.

Os professores Valquíria, Sonara, Gabriel e Américo atuam como professores na Educação Básica e são responsáveis, diretamente, pela realização do projeto nas suas unidades escolares. A professora Rosani atua na Educação Superior e, também, como mediadora de dois professores, sendo um deles o professor Américo, na Educação Básica; juntos realizaram o projeto em duas unidades escolares no município de Mococa.

Optamos por colher dados por meio de entrevistas com o apoio de um roteiro (APÊNDICE A). Os dados coletados foram tratados de forma qualitativa e descritiva para uma posterior análise criteriosa, buscando analisar os dados em toda a sua riqueza.

Diante do exposto, concordamos com Bogdan e Biklen (1994, p. 50) que "[...] a abordagem da investigação qualitativa exige que o mundo seja examinado com a ideia de que nada é trivial, que tudo tem potencial para constituir uma pista que nos permita estabelecer uma compreensão mais esclarecedora no nosso objeto de estudo". Os referidos autores auxiliam-nos a compreender os procedimentos para a coleta e tratamento de dados. Nesse sentido, convém salientar que

À medida que um investigador vai passando mais tempo com os sujeitos, a relação torna-se menos formal. O objectivo do investigador é o de aumentar o nível de à vontade dos sujeitos, encorajando-os a falar sobre aquilo de que costumam falar, acabando por lhe fazer confidências [...] o investigador entra no mundo do sujeito e registra de forma não intrusiva o que vai acontecendo e recolhe, simultaneamente, outros dados descritivos. Tenta

\footnotetext{
40 O professor morava nesse município quando realizou o projeto por meio de uma parceria entre a Universidade Estadual Paulista - UNESP, Faculdade de Filosofia e Ciências de Marília e a Escola estadual Professora Oracina Corrêa Moraes Rodine, até o final de 2018, sob a coordenação da Prof. ${ }^{\text {a }}$ Dr. ${ }^{a}$ Sílvia Aparecida de Souza Fernandes. No ano de 2019, o professor mudou-se para o município de Araraquara-SP.
} 
aprender algo através do sujeito [...] pode participar nas suas actividades, embora de forma limitada. Aprende o modo de pensar do sujeito, mas não pensa do mesmo modo. (BOGDAN; BIKLEN, 1994, p. 113).

Consideramos a coleta de dados um momento de intenso aprendizado para o pesquisador e para os entrevistados, pois ambos trocam vivências e visões de mundo. Nesta investigação, optamos por dar a "voz" para os participantes no sentido de permitir que eles colocassem, abertamente, suas impressões sobre o projeto.

Para contribuir com esta investigação, admitimos que "[...] na análise qualitativa é a presença ou a ausência de uma característica de conteúdo ou de um conjunto de características num determinado fragmento de mensagem que é tomada em consideração" (BARDIN, 2016, p. 27). No caminho de construção das análises, pautamo-nos nas características dos conteúdos trazidos à tona nas falas dos professores participantes. Fragmentos foram analisados e levados em consideração à luz do referencial teórico em torno da educação geográfica, cidadania, trabalho de campo, estudo do meio e do projeto Nós Propomos!.

\subsection{Os professores participantes e a coleta de dados no estado de São Paulo}

Foram convidados a participar quatro professores de Geografia e uma Cientista Social que atuaram na implantação e desenvolvimento do projeto nos municípios de Ibitinga, Mococa, Serrana e Marília, todos localizados no estado de São Paulo, no Brasil. Eles foram os responsáveis por desenvolver o projeto entre os anos de 2017 e $2019^{41}$. No caso da região metropolitana de Ribeirão Preto-SP, as professoras participantes, Sonara, Valquíria e Rosani foram contatadas pessoalmente e aceitaram de imediato. As professoras são membros do ELO. O professor Américo participou do projeto por meio da mediação da professora Rosani, em Mococa-SP. No caso de Marília-SP, o professor Gabriel foi contactado por email e, também, aceitou prontamente.

Destacamos o fato de tentarmos contato com um sexto professor que trabalhou com o projeto em Mococa, por mediação da professora Rosani, no entanto não conseguimos contato com o mesmo, em tempo hábil, para a realização dos trâmites legais e burocráticos. Além disso, o panorama para a realização de coleta de dados por meio da entrevista fícou impossibilitada pela situação imposta pela pandemia com relação à COVID-19 $9^{42}$.

\footnotetext{
${ }^{41}$ Para esta investigação propusemos um recorte do início das atividades do projeto até o final de 2019 para facilitar a coleta e análise dos dados dentro do cronograma apresentado no projeto de pesquisa deste trabalho de mestrado. Destacamos o fato de as atividades continuarem no ano de 2020.

42 A pandemia da COVID-19 instalada pelo novo corona vírus forçou os países a adotarem vários protocolos para contenção, dentre eles o isolamento social. Para mais informações, sites:
} 
O professor Gabriel envolveu-se com o projeto quando houve a apresentação do mesmo na escola em que lecionava. A apresentação foi feita por integrantes do Centro de Pesquisas e Estudos Agrários e Ambientais (CPEA), coordenado pela Professora Dr. ${ }^{a}$ Sílvia Aparecida de Sousa Fernandes, da Faculdade de Filosofia e Ciências, na Universidade Estadual Paulista (UNESP) ${ }^{43}$, no ano de 2017.

Como apresentado anteriormente, tanto a USP como a UNESP realizaram diálogo com o Instituto de Geografia e Ordenamento do Território-IGOT, da Universidade de Lisboa-UL, em Portugal, por meio do Professor Dr. Sergio Claudino, para a realização do projeto no estado de São Paulo, no Brasil.

Cabe destacar, já citado anteriormente, que o professor pesquisador desta investigação também realizou práticas pedagógicas envolvendo o projeto Nós Propomos! no município de Ribeirão Preto nos anos de 2018 e 2019, no entanto não é objeto desta investigação por entender que é necessário um olhar de estranhamento (OLIVEIRA, 1996) para o tema a ser investigado.

Além disso, optamos por não utilizarmos a metodologia da pesquisa-ação, no qual o próprio pesquisador é objeto da pesquisa. Em contrapartida, temos o estudo de Halaszen (2020) que utilizada a referida metodologia para analisar as potencialidades e os limites das tecnologias geocolaborativas no desenvolvimento do pensamento geográfico no ensino de geografia, por meio do projeto Nós Propomos!

A nossa investigação envolve entrevistas com professores, portanto, o projeto foi submetido ao Comitê de Ética em Pesquisa (CEP) da FFCLRP/USP, e foi realizada a inserção na Plataforma Brasil do projeto de pesquisa, do roteiro de entrevista e do Termo de Consentimento Livre e Esclarecido (TCLE). Deixamos claro que todas as providências para garantir sigilo e respeito aos participantes foram, por nós, tomadas. Após a aprovação pelo CEP (ANEXO A), com data de 21 de maio de 2019, iniciamos as entrevistas.

O TCLE é um documento obrigatório que compõe as pesquisas com seres humanos no Brasil, portanto, o projeto passou pela Comissão Nacional de Ética em Pesquisa (CONEP) por meio da inserção na Plataforma Brasil. O processo descrito está previsto na resolução 196/1996 do Conselho Nacional de Saúde, vinculado ao Ministério da Saúde, no Brasil.

Existe certa dificuldade de realização de pesquisas no campo educacional, no Brasil, por conta do preenchimento dos formulários e das próprias avaliações feitas pelas comissões.

https://www.who.int/emergencies/diseases/novel-coronavirus-2019/advice-for-public e https://www.unasus.gov.br/especial/covid19. Acesso em: 20 mar. 2020.

${ }_{43}$ A referida professora é membro do Grupo de Estudos da Localidade - ELO. Tal aspecto facilitou o nosso contato com o professor Gabriel. 
O trâmite é complexo e demorado, o que pode atrasar a coleta de dados. Sobre as dificuldades de tramitação das pesquisas na área das Ciências Humanas e Sociais, a Associação Nacional de Pós-Graduação e Pesquisa em Ciências Sociais - ANPOCS publicou uma moção ${ }^{44}$. Assim, temos que

Desde sua vigência, então, parte significativa das pesquisas em ciências
sociais e humanas, quer tratasse ou não de questões relativas à saúde, teve
que se submeter ao regime da avaliação pelo sistema CONEP/CEPs,
enfrentando-se, numa situação de antemão desfavorável, com o
desconhecimento e a intromissão indevida de profissionais treinados em
outras lógicas científicas, hegemônicos no sistema, o que evidenciou, na
prática, o descompasso da referida resolução em relação aos problemas
éticos nas pesquisas em ciências sociais e humanas. (ANPOCS, 2011).

Nos cinco casos dos nossos participantes, após a confirmação das entrevistas, foi apresentado aos professores o TCLE (APÊNDICE B). Objetivamos que eles tomassem ciência dos detalhamentos e da contribuição da investigação para o ensino de Geografia e para a Educação.

O termo foi lido em voz alta e em seguida assinado por cada um dos cinco professores. No referido termo, foi comunicado que os nomes completos deles seriam preservados. Juntamente com o TCLE, foi apresentado o termo de aprovação da investigação pela CEP (ANEXO A). A coleta de dados com os professores foi feita em locais e horários acordados previamente e de acordo com a disponibilidade deles. Após o processo de entrevistas, inserimos na Plataforma Brasil o relatório parcial (ANEXO B), como forma de apresentação dos encaminhamentos da pesquisa.

As entrevistas foram feitas seguindo roteiro (APÊNDICE A). Após a coleta, e com a autorização dos participantes, os áudios gravados foram transcritos de forma integral para serem analisados. O roteiro foi pensado a partir do referencial teórico e das nossas próprias experiências como professores inseridos no projeto no município paulista de Ribeirão Preto SP.

De acordo com Zago (2003, p. 287), “[...] os instrumentos adotados na coleta de dados somente ganham sentido quando articulados à problemática de estudo". Nesse caso, entendemos que não é a quantidade de entrevista que importa, mas, sim, a qualidade das mesmas e sua coesão com a investigação e seus objetivos.

\footnotetext{
44 A moção pode ser acessada pelo site da ANPOCS que está disponível no seguinte endereço eletrônico https:// anpocs.com/index.php/universo/mocoes-sp-1243763237/755-mocao-etica-em-pesquisa-28102011. Acesso em: 10 de out 2019.
} 
Sobre a entrevista, Gil (2011, p. 109) a define como “[...] técnica em que o investigador se apresenta frente ao investigado e lhe formula perguntas com o objetivo de obtenção dos dados que interessam à investigação". A entrevista, ainda, de acordo com o autor, é uma forma de interação social. Nesse mesmo caminho, Romanelli, (1998, p. 125) acrescenta que a entrevista

[...] é uma relação didática, que cria uma forma de sociabilidade específica, limitada no tempo, sem continuidade, em que, inicialmente, os parceiros da díade se defrontam como estranhos, pautados por uma alteridade que aparentemente não admite o encontro e que deve ser superada para que a matéria prima do conhecimento possa ser produzida durante esse encontro que transforma estranhos em parceiros de troca.

Consideramos, portanto, que a entrevista possibilita uma troca de experiências e visões de mundo intensas. Elas possibilitam o levantamento de conteúdos sobre fatos, atitudes, sentimentos, padrões de ação, comportamento de presente ou passado (GIL, 1999). De modo geral, na presente investigação, os cinco professores dialogaram de forma produtiva sobre a sua formação acadêmica e demais questões colocadas.

Destacamos que o momento da entrevista é marcado por "[...] saberes e experiências [...] da vida do informante só interessa aquilo que vem se inserir diretamente no domínio da pesquisa" (DUARTE, 2002, p. 147). Desta forma, buscamos focar nas temáticas do projeto.

Para além disso, a entrevista “[...] é um processo complexo que tem um caráter reflexivo, num intercâmbio contínuo entre os significados e o sistema de crenças e valores, perpassados pelas emoções e sentimentos dos protagonistas” (SKYMANSKI, 2018, p. 13). Portanto, podemos admitir as entrevistas como uma intensa relação social em determinado momento da pesquisa e uma rica ferramenta para o nosso trabalho investigativo.

Nessas entrevistas, consideramos o campo de estudo com um olhar de “estranhamento”. No sentido destacado por Romanelli (1998, p. 123),

é imprescindível incluir na pesquisa a análise de campo da investigação, isto é, o contexto histórico e os determinantes estruturais que ordenam a sociedade moderna, a fim de recuperar o modo como determinados objetos empíricos articulam-se com a sociedade global [...] antes de mais nada o trabalho de campo deve ser orientado e guiado pelo olhar antropológico, que se funda no estranhamento e no conhecimento teórico.

As cinco entrevistas realizadas por nós consideraram o sujeito na sua complexidade e dentro de um contexto cultural específico. Entendemos que a "[...] entrevista oferece um material de observação bastante rico. O local é uma condição importante na produção dos 
dados, podendo facilitar ou produzir constrangimentos" (ZAGO, 2003, p. 298). Optamos por realizar as entrevistas fora do local de trabalho dos participantes, ou seja, fora de suas escolas. Escolhemos um lugar calmo, isolado e acolhedor para ambas as partes.

Para além dos aspectos já mencionados anteriormente, destacamos a necessidade da solidariedade com o outro no ato da pesquisa, seja na entrevista ou mesmo na divulgação dos resultados. É importante pensar a pesquisa em uma dimensão ética, sendo o pesquisador o agente e produtor do conhecimento e possuidor de responsabilidade (SEVERINO, 2015).

A escrita e a forma de atenção ao tratamento dos dados são fundamentais para conseguirmos elaborar uma investigação que atenda à ética científica e humana e que possa ser, de fato, estruturante na construção do conhecimento sobre a educação geográfica e a cidadania.

Como forma de praticar esses elementos apresentados, os participantes desta investigação tiveram contato com o projeto de pesquisa e foram convidados a participar da investigação. Suas identidades completas foram mantidas em sigilo, sendo exposto somente seu primeiro nome. Deixamos claro que eles poderiam acompanhar todas as fases da investigação, podendo, inclusive, desistir de participar em qualquer momento, sem que isso lhes causasse qualquer transtorno ou prejuízo de qualquer natureza.

Concordamos com Alves-Mazzotti (2003) que, em pesquisas que envolvem professores, estes devem ser considerados protagonistas da Educação. Isso significa fazer pesquisa "com" professores e não somente "para" professores. De acordo com a autora, a relevância e a divulgação dos resultados das pesquisas em Educação podem favorecer as mudanças tão almejadas no contexto pedagógico brasileiro.

Após a realização das entrevistas, sua transcrição e as sucessivas leituras do material coletado, elaboramos algumas categorias para análise dos dados. A organização em categorias de análise das entrevistas transcritas atende os objetivos propostos nesta investigação. Neste sentido, Bardin (2016, p. 147) afirma que

[...] a categorização é uma operação de classificação de elementos constitutivos de um conjunto por diferenciação, e, em seguida, por reagrupamento segundo gênero, com os critérios previamente definidos. As categorias são rubricas ou classes, as quais reúnem um grupo de elementos sob um título genérico, agrupamentos esses efetuados em razão das características comuns destes elementos

A reflexão da autora é produtiva no sentido de apresentar o conceito de categorias e como olhar para as fontes coletadas e "agrupar" e/ou "reagrupar" as falas dos participantes 
para dar sentido às interpretações que são feitas a posteriori. Isto posto, segundo Lüdke e André (1986, p. 49), após a categorização, o pesquisador deve

[...] acrescentar algo à discussão já existente sobre o assunto focalizado. Para isso, ele terá que fazer esforço de abstração, ultrapassando dos dados, tentando estabelecer conexões, e relações que possibilitem a proposição de novas explicações interpretativas [...] Este acréscimo pode significar desde um conjunto de proposições bem concatenadas e relacionadas que configurem uma nova perspectiva até o simples levantamento de novas questões que precisarão ser mais sistematicamente explorados.

As categorias criadas para a análise do material coletado têm a função de atingir os objetivos propostos na investigação e, em especial, de avaliar os impactos das ações educativas para a formação cidadã, sob a ótica dos próprios professores participantes. Desta forma, estabelecemos as seguintes categorias de análise:

a) O projeto e a formação cidadã;

b) Relevância da saída de sala de aula;

c) Contribuições do projeto para os professores e para os alunos.

\subsection{Caracterização dos professores participantes}

Apresentamos, a seguir, a caracterização dos professores participantes com informações que julgamos necessárias.

Quadro 1 - Caracterização dos participantes - informações preliminares

\begin{tabular}{|c|c|c|c|c|}
\hline $\begin{array}{c}\text { Professore } \\
\text { s }\end{array}$ & Formação acadêmica & $\begin{array}{l}\text { Tempo de } \\
\text { docência }\end{array}$ & $\begin{array}{c}\text { Anos de } \\
\text { realização } \\
\text { do projeto }\end{array}$ & Idade \\
\hline Valquíria & $\begin{array}{l}\text { Graduada em Ciências Sociais na Fundação } \\
\text { Santo André (1994). Formação pedagógica em } \\
\text { Geografia (1999). Mestre em Educação, pela } \\
\text { Universidade de São Paulo (2014). }\end{array}$ & 23 anos & $2018-2020$ & $\begin{array}{c}51 \\
\text { anos }\end{array}$ \\
\hline Sonara & $\begin{array}{l}\text { Graduada em História pela São Luís de } \\
\text { Jaboticabal (2007), em Geografia pela Barão } \\
\text { de Mauá (2010) e em Pedagogia pela } \\
\text { Universidade Metropolitana de Santos (2014). } \\
\text { Especialização em Mídias na Educação pela } \\
\text { Universidade Federal de São João Del Rei } \\
\text { (UFSJ). Mestre em Educação pela } \\
\text { Universidade de São Paulo (2018). }\end{array}$ & 13 anos & $2018-2019$ & $\begin{array}{c}32 \\
\text { anos }\end{array}$ \\
\hline
\end{tabular}




\begin{tabular}{|c|l|c|c|c|}
\hline Gabriel & $\begin{array}{l}\text { Graduado em Geografia pela Universidade } \\
\text { Estadual Paulista - Ourinhos (2015) e Mestre } \\
\text { em Geografia pela Universidade Estadual de } \\
\text { Londrina (2019). }\end{array}$ & 6 anos & $2017-2019$ & $\begin{array}{c}31 \\
\text { anos }\end{array}$ \\
\hline Rosani & $\begin{array}{l}\text { Graduada em Ciências Sociais na Pontifícia } \\
\text { Universidade Católica (1988). Mestre em } \\
\text { Ciências Sociais pela Universidade de São } \\
\text { Paulo (1997). }\end{array}$ & 20 anos & $2018-2020$ & 56 \\
Amórico
\end{tabular}

Fonte: elaborado pelo autor

Salientamos que a professora Rosani é a única que não apresenta graduação em Geografia. Neste caso, ela não é a professora atuante, diretamente, na sala de aula, mas, sim, uma mediadora $^{45}$ de outros dois professores de Geografia que realizam o projeto, em diferentes unidades escolares. Um desses dois é o professor Américo.

Quatro dos cinco professores participantes possuem o título de mestre em diferentes universidades públicas, seja em Educação, como as professoras Sonara e Valquíria, em Ciências Sociais, como a professora Rosani, ou em Geografia, como o professor Gabriel.

Outro ponto a ser mencionado são as diferentes idades e tempos de magistério dos professores participantes. Isto traz como indício a diversidade de experiências docentes vivenciadas pelos participantes.

Notamos que os cinco professores desenvolvem o projeto em escolas da rede estadual (E.E) pública de ensino. A professora Rosani atua, também, na rede privada de ensino, como mediadora de um professor de Geografia. Isto posto, salientamos que o projeto pode ser realizado em diferentes redes de ensino ${ }^{46}$. No quadro 1 também está explicitado os anos em que o projeto foi realizado. Salientamos que em Mococa o projeto ainda não foi finalizado, em Ibitinga continua com outra turma e em Rincão iniciou, no ano de 2020.

Como mencionamos anteriormente, o recorte desta investigação corresponde aos anos de implantação do projeto no estado de São Paulo (no ano de 2017), e ao final do ano de 2019

\footnotetext{
${ }^{45}$ A professora atuou como mediadora com os dois professores que desenvolveram as práticas em escolas da Rede Privada e Pública de ensino de Mococa/SP. No caso, ela conduziu reuniões de planejamento e desenvolvimento do projeto com os dois professores e participou de alguns trabalhos de campo com os docentes e as turmas envolvidas. Neste sentido, ela articulou as ações do projeto como formadora de professores.

${ }^{46}$ A obra "Geografia, Educação e cidadania", organizada por Claudino et al. (2019), apresenta um compêndio de muitas práticas desenvolvidas tanto em escolas da rede pública quanto privadas, na Educação Básica e na Superior.
} 
(devido aos prazos de coleta de dados, análise das entrevistas e defesa deste trabalho acadêmico).

Quadro 2 - Caracterização dos participantes - informações complementares

\begin{tabular}{|c|c|c|c|}
\hline $\begin{array}{c}\text { Professo } \\
\mathbf{r}\end{array}$ & Rede de ensino & $\begin{array}{c}\text { Município atuante do } \\
\text { projeto }\end{array}$ & $\begin{array}{c}\text { Nível de ensino } \\
\text { atuante }\end{array}$ \\
\hline Valquíria & $\begin{array}{c}\text { Pública } \\
\text { estadual }\end{array}$ & Ibitinga/SP & Básico \\
\hline Sonara & $\begin{array}{c}\text { Pública } \\
\text { estadual }\end{array}$ & Serrana/SP & Básico \\
\hline Gabriel & $\begin{array}{c}\text { Pública } \\
\text { estadual }\end{array}$ & Marília/SP & Básico \\
\hline Rosani & Privada & Mococa/SP & Superior \\
\hline Américo & Púbica estadual & Mococa/SP & Básico \\
\hline
\end{tabular}

Fonte: elaborado pelo autor

O quadro 2 explicita os nomes dos cinco professores participantes, a rede de ensino, o município e a esfera de atuação. Observamos que apenas uma professora atua na rede privada, e no ensino superior.

Categorizamos os professores participantes em dois grandes grupos para análise das entrevistas. Essa forma de categorização foi criada para respeitar a diversidade de ação dos professores e dar a eles o devido lugar de fala. Os dois grupos são mostrados no quadro 3 a seguir.

Quadro 3 - Categorias de análise quanto ao nível de atuação dos participantes

\begin{tabular}{|c|c|c|c|}
\hline Professores & $\begin{array}{c}\text { Rede de } \\
\text { ensino }\end{array}$ & $\begin{array}{c}\text { Esfera de } \\
\text { ensino atuante }\end{array}$ & Tipo de atuação \\
\hline $\begin{array}{c}\text { Valquíria, Sonara, } \\
\text { Gabriel e Américo }\end{array}$ & $\begin{array}{c}\text { Pública } \\
\text { (estadual) }\end{array}$ & Básico & $\begin{array}{c}\text { Professor atuante no } \\
\text { projeto de forma direta }\end{array}$ \\
\hline Rosani & Privada & Superior & $\begin{array}{c}\text { Mediadora do projeto } \\
\text { com dois professores }\end{array}$ \\
\hline
\end{tabular}

Fonte: elaborado pelo autor 


\title{
5 O PROJETO NÓS PROPOMOS! DESCRIÇÃO E ANÁLISE
}

\author{
A grande ruptura do Projeto Nós Propomos! reside, \\ precisamente, em colocar a escala local no centro da disciplina \\ de Geografia e de se assumir, de forma inequívoca, o \\ compromisso da escola na construção de uma comunidade \\ mais harmônica e sustentável. \\ (CLAUDINO et al., 2019, p. 6)
}

Nesta seção apresentamos uma descrição do projeto Nós Propomos! em Portugal, em seguida na ibero-américa para chegarmos ao Brasil e focarmos nossa atenção no estado de São Paulo. Juntamente com a descrição, tecemos considerações sobre ampliação do projeto para fora de terras portuguesas e de algumas contribuições do projeto, no sentido de promover um ensino de Geografia inovador e voltado tanto para o global quanto para o local.

\subsection{O Projeto "Nós Propomos! cidadania e inovação na educação geográfica"}

O projeto "Nós Propomos! cidadania e inovação na educação geográfica" 47 , é coordenado pelo Professor Dr. Sergio Claudino, do Instituto de Geografia e Ordenamento do Território (IGOT), na Universidade de Lisboa, em Portugal. Por meio do projeto, o aluno é valorizado como agente protagonista de sua realidade local, além de "[...] ajudar a identificar os problemas socioambientais locais e favorecer a busca de soluções na vida política da comunidade" (SOUTO GONZÁLEZ; CLAUDINO, 2019, p. 8). A experiência de realização do Projeto Nós Propomos! em Portugal levou o coordenador do mesmo a buscar parcerias para sua realização em outros países, inclusive no Brasil.

Para entendermos a relevância e as características marcantes do projeto, temos que realizar uma apresentação da sua origem nos estudos de Geografia das escolas portuguesas. Não é nossa intenção estabelecer um traçado histórico da constituição da Geografia como disciplina nos currículos portugueses, mas, sim, mostrar como ela é resultante da necessidade das autoridades portuguesas em legitimar os estudos territoriais.

Em Portugal, na instrução secundária ${ }^{48}$, os estudos geográficos eram ensinados por meio de uma disciplina que compreendia História, Geografia e Cronologia (CLAUDINO, 2000); a valorização da questão colonial levou, em 1888, a disciplina de Geografia se tornasse

\footnotetext{
${ }^{47}$ As publicações encontradas trazem o nome do projeto com e sem ponto de exclamação (!). Optamos pelo uso da exclamação uma vez que ela enfatiza o empoderamento, pretendido pelo projeto tendo em vista a educação geográfica para a cidadania.

48 Essa etapa da Educação portuguesa é semelhante ao Ensino Médio no Brasil.
} 
autônoma, pela primeira vez, em relação à disciplina de História, ao contrário do que sucedeu na Espanha ou na França. Ocorreram várias reformas educacionais ${ }^{49}$, revelando a disciplina de Geografia uma grande sensibilidade às questões ideológicas, como a valorização de Portugal após a Revolução de 1974 ou a atenção à Europa, com o ingresso na União Europeia - UE (CLAUDINO, 2015). Assim, a referida disciplina foi sendo alterada ao longo dos séculos.

Em 1987, foram criados os cursos de formação inicial de professores em universidades portuguesas, em departamentos específicos de Geografia (CLAUDINO, 2015). Na reforma do começo dos anos 1990, valorizam-se as capacidades e atitudes, a par dos conhecimentos. Em 2001, a reorganização curricular aposta num ensino por competências, o que será contrariado pelas Metas Curriculares, de caráter mais tradicional, implementadas a partir de 2013 (CLAUDINO, 2015). Desde fins de 2017, são implementadas as Aprendizagens Essenciais que recuperam muito do discurso de um ensino por competências.

O ensino de Geografia é composto por diferentes correntes teóricas, como Geografia Humanista, Geografia Radical, Geografia Crítica ou Geografia da Percepção. Interessa aqui entender que “[...] essas 'geografias' valorizam, nas suas preocupações, a justiça social, a pobreza, as alterações climáticas, as desigualdades." (SOUTO GONZÁLEZ; CLAUDINO, 2019, p. 5).

Ao longo dos anos 2000, cresce o apelo da União Europeia, em forma de discursos e de práticas, por uma maior integração entre os países, por meio dos diálogos - entre governantes e governados, no sentido de a própria população agir sobre seu território estimulando uma cidadania territorial e a própria governança (CLAUDINO, 2014). Neste cenário, estabelecem-se em, Portugal, políticas educacionais para rever o ensino de Geografia.

Em Portugal, na instrução secundária, os estudos geográficos eram ensinados por meio de um ensino de Geografia Tradicional e com predomínio conteudista, que é questionado por meio da formação de uma comissão, das comunidades europeias na ONU, para a valorização da localidade e da governança territorial por parte dos cidadãos, por meio de um ensino de Geografia Crítica, com pensamento sensível para o lugar e o local (CLAUDINO, 2014).

A referida ideia de governança sinaliza “[...] a defesa de uma participação mais intensa e diversificada de atores no processo de decisão de iniciativa ou de responsabilidade pública e uma maior participação por parte dos cidadãos [...]” (FERRÃO, 2014, p. 58). Desta forma, embora aumente a importância do olhar para a localidade nos estudos geográficos, nesse cenário podemos identificar que a escala local

\footnotetext{
49 Cabe aqui citar somente as mais recentes que reorganizaram os conteúdos, tempos das aulas e concepção de ensino de Geografia na Educação escolar portuguesa.
} 
[...] surge habitualmente esquecida nos currículos e, sobretudo, nas práticas escolares - no ensino secundário/médio, as alusões à realidade histórica e territorial da comunidade surgem como opcionais e de ilustração do que se estudou no mundo ou no país, sem que a comunidade constitua, em si mesma, um objeto de estudo. (SOUTO GONZÁLEZ; CLAUDINO, 2019, p. 4).

No ano de 2004, na disciplina Geografia A, do Ensino Secundário (destinado a alunos de 15 a 18 anos), específica para os estudantes da área de Humanidades e de Ciências Socioeconômicas, surgiu o Estudo de Caso. Ao final da disciplina, os alunos são submetidos a um exame nacional. Nessa nova sistemática de trabalho, a Geografia nos últimos anos

[...] centra-se no estudo de Portugal e identifica-se a educação para a cidadania como objetivo último do processo educativo. Em coerência com este discurso, surge a grande novidade do programa: a realização de um Estudo de Caso, um trabalho de índole mais prática e muito direcionado para uma ativa cidadania local. Este é apresentado como 'uma oportunidade efetiva de introduzir o conhecimento da realidade no trabalho em Geografia' e concretiza-se que os alunos devem 'Analisar criticamente problemas que afectam a região onde vive, refletindo sobre soluções possíveis para os problemas detectados'. Assim, é o próprio programa da disciplina que torna obrigatória a implementação de um estudo de índole mais prática sobre o meio local e direcionado para a resolução dos problemas locais. (CLAUDINO, 2014, p. 4).

Mesmo diante disso, no entanto, muitos professores continuam a valorizar o exame nacional, de onde o Estudo de Caso estava arredado, e onde focavam-se nos conteúdos de forma tradicional, ao invés de desenvolver aquele, voltado para a pesquisa e os problemas locais. Neste sentido, existe um ensino tradicional português, ainda no século XXI, que "[...], subsiste a escala local, quanto muito tomada para ilustração do que se aborda no país ou no mundo, mas que não constitui, em si mesma, objeto de estudo" (CLAUDINO, 2018b, p. 6).

Assim, no Centro de Estudos Geográficos do Instituto de Geografia e Ordenamento do Território, da Universidade de Lisboa/IGOT-UL, foi lançado o "Projeto Nós Propomos! cidadania e inovação na educação geográfica" como uma tentativa de valorizar a cidadania local nas escolas portuguesas, também numa perspectiva de uma renovação da Educação geográfica em Portugal. O projeto logo se expandiu por várias escolas portuguesas, desenvolvendo parcerias com outras instituições em Portugal.

Figura 5 - Escolas portuguesas participantes no Projeto Nós Propomos! 2011/12-2017/18 


\begin{tabular}{|c|c|c|c|c|c|c|c|}
\hline Ano & $2011 / 12$ & $2012 / 13$ & $2013 / 14$ & $2014 / 15$ & $2015 / 16$ & $2016 / 17$ & $2017 / 18$ \\
\hline$N^{\circ}$ & 9 & 8 & 16 & 37 & 46 & 57 & 46 \\
\hline
\end{tabular}

Fonte: Claudino (2018b, p. 15)

Notamos na figura 5, o número crescente de escolas portuguesas que fazem adesão ao projeto $^{50}$, ou seja, o projeto está se expandindo internamente e também externamente por muitas áreas. O mapa, a seguir, (figura 6) apresenta a espacialização das escolas em Portugal que estão inseridas no projeto. Neste sentido, percebemos que o projeto está consolidado em seu país de origem.

Figura 6 - "Projeto Nós Propomos! cidadania e inovação na educação geográfica" 2019/2020.

Universidades da península Ibérica e instituições portuguesas

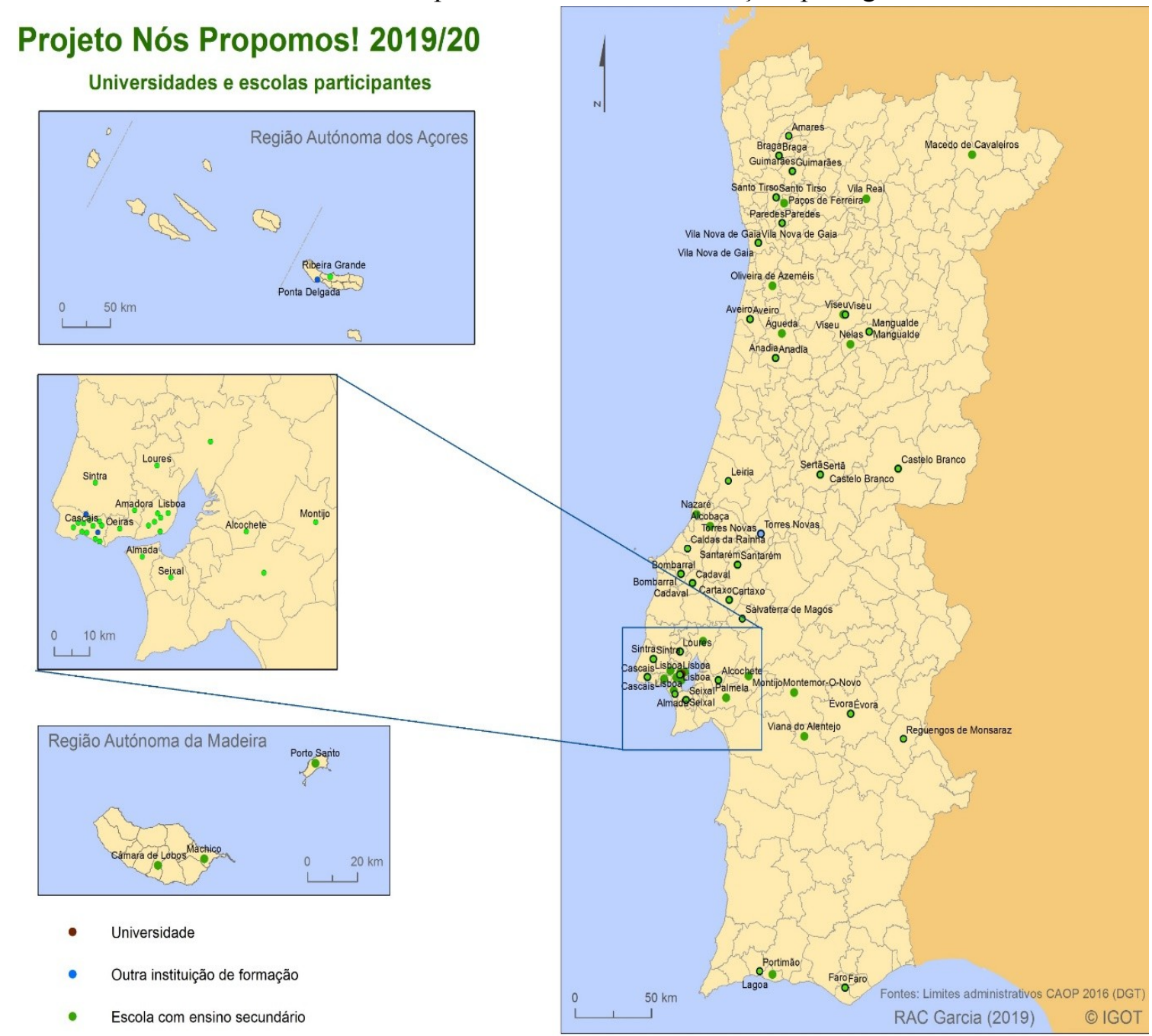

Fonte: (CLAUDINO, 2019b, p. 376)

50 O projeto contempla, para os anos de 2018/19, 58 escolas, para os anos de 2019/20: 61 escolas. Estes dados foram enviados por Sérgio Claudino, idealizador do Projeto Nós Propomos!, no dia 10 de março de 2020. 
Em Portugal ${ }^{51}$, o Projeto iniciou-se entre 2011/12 e estabeleceu-se para todo o país, incluindo, também, as regiões autônomas e insulares ${ }^{52}$. Envolve, atualmente, milhares de alunos e professores, cerca de 50 escolas de Educação Básica e 40 universidades iberoamericanas (BAZOLLI et al., 2017). O Projeto vem crescendo e continua a se expandir ${ }^{53}$.

O Projeto estabeleceu parcerias com autarquias, empresas, associações e órgãos públicos, um indicativo de ampla consolidação em várias localidades em Portugal, no Brasil, na Espanha, no Peru, na Colômbia, em Moçambique e no México (FITA ESTEVE; CLAUDINO; SOUTO GONZÁLVEZ, 2018).

No caso de Portugal, a Universidade de Lisboa (UL) faz a coordenação e estabelece vínculos com os parceiros que irão desenvolver as atividades. Desde sempre, existiu uma grande aposta nos municípios como parceiros. Estabelecem-se acordos protocolados com a universidade e as escolas, nos quais aqueles se comprometem a apoiar o projeto. Durante esse processo de planejamento das ações,

[...] é lançado o convite às escolas que desejem participar. Realiza-se, então, um seminário com os professores envolvidos, no IGOT/Universidade de Lisboa, de formação e de planificação das atividades a desenvolver ao longo do ano letivo. A equipe coordenadora do projeto desloca-se a cada uma das escolas participantes, em sessões onde são apresentados os respectivos objetivos e metodologia e se inicia a discussão dos projetos que os alunos vão desenvolver. (CLAUDINO, 2014, p. 5).

Em Portugal, essa parceria continua durante o desenvolvimento do projeto, por meio de replanejamentos e reuniões com os professores das unidades escolares, os professores universitários e os agentes do poder público local. Atualmente, conta com o apoio do Ministério da Educação português (CLAUDINO, 2018b).

\footnotetext{
51 As escolas portuguesas que desenvolvem o projeto atualmente estão registradas no seguinte site http://nospropomos2016.weebly.com/escolas-participantes-201819.html. Acesso em: 29 nov. 2019.

52 Salientamos os territórios das ilhas da Madeira e dos Açores.

53 Não encontramos estatísticas oficiais do número exato de participantes na ibero-américa e nem no Brasil até o mês de junho de 2020, momento de fechamento da escrita desta investigação.
} 
Figura 7 - As parcerias do "Projeto Nós Propomos! cidadania e inovação na educação geográfica"

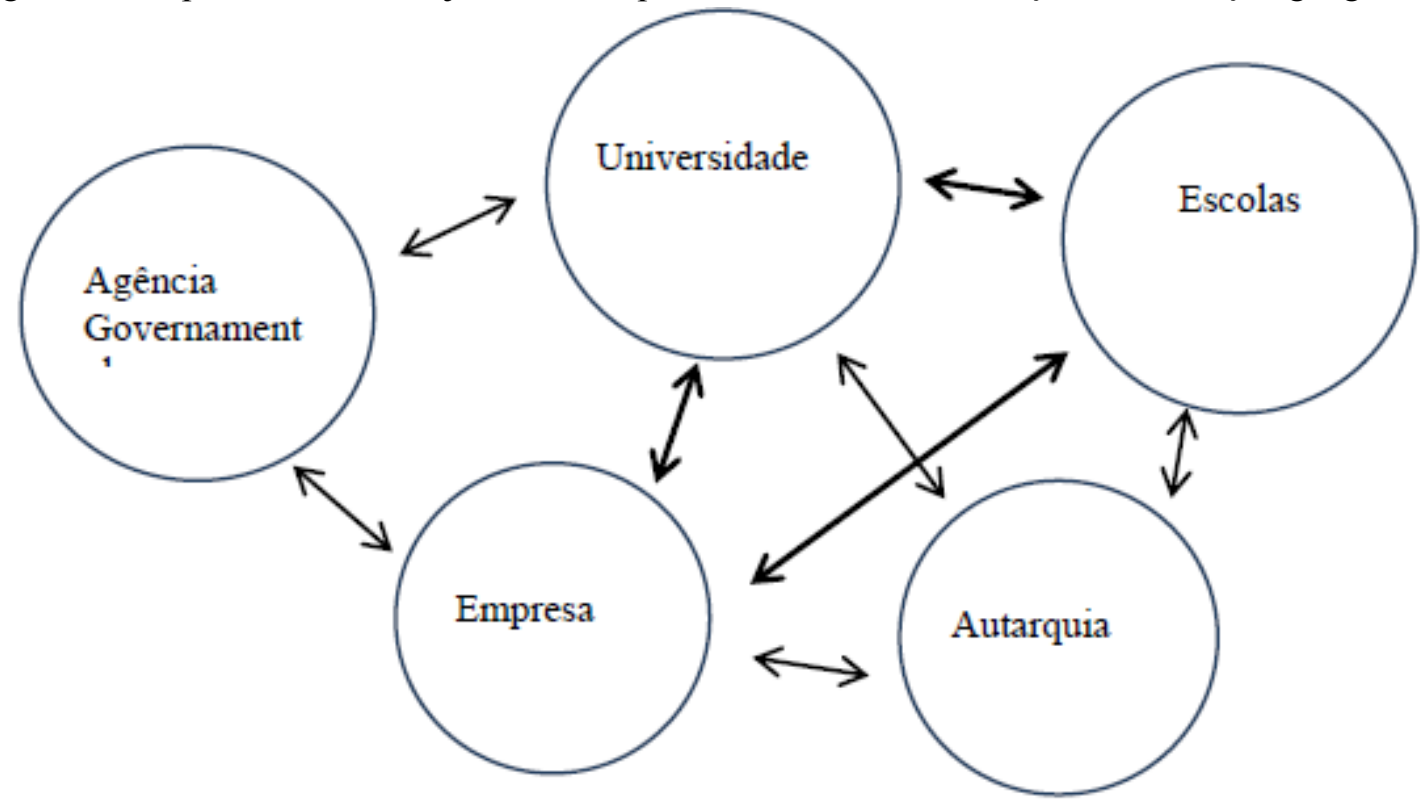

Fonte: Claudino (2014, p. 6)

Observamos pela figura 7 a complexidade de relações estabelecidas entre instituições portuguesas para o desenvolvimento do projeto $^{54}$. Em Portugal, essas parcerias estão mais consolidadas e estão em fase de municipalização do projeto, ou seja, as prefeituras estão institucionalizando o referido projeto em suas ações na Educação Local.

Notamos que o projeto apresenta uma configuração própria e muito sólida em seu território de origem. Existe um processo de municipalização em curso em Portugal, o qual conta com o apoio da Direção-Geral de Educação/Ministério da Educação. Claudino (2019a, p. 40) evidencia esse processo:

\begin{abstract}
Alguns municípios têm evidenciado um grande envolvimento no desenvolvimento do Projeto. Assim, em 17 de julho de 2019, numa parceria entre a Câmara Municipal de Cascais e o IGOT, foi criada a Rede Internacional de Municípios Nós Propomos!, materializando o referido envolvimento dos municípios no Projeto.
\end{abstract}

A parceria com o poder local e a presença de um planejamento de ações em forma de registros e em reuniões com representantes locais asseguram a consolidação do projeto de forma ampla e produtiva. Em alguns casos, as “[...] propostas diretamente implementadas pelo poder local, geralmente com adaptações, a influência da divulgação das propostas dos alunos é muito superior à que é imediatamente perceptível" (CLAUDINO, 2019a, p. 47). Por meio desse processo de municipalização em Portugal e da consolidação das parcerias estabelecidas,

\footnotetext{
54 Importante destacar que existem parcerias semelhantes, com algumas adaptações, no território brasileiro.
} Essas parcerias são estruturadas de modos distintos em cada estado da federação. 
existem cerca de 12 mil estudantes com 2 mil projetos produzidos até o momento. (CLAUDINO, 2019a, 2019b).

Na Espanha, entre 2016 e 2017, o Projeto chegou em primeiro lugar à Ciudad Real, pela articulação entre a Universidade de Castilla-La Mancha e o município local. A partir desse momento,

[...] chegou à Valência, Ontinyent e Xàbia, onde se conta, tal como na Ciudad Real, com a participação de alunos da Educação Secundária e Primária e com o apoio do município. No mês de março de 2018, celebrouse um Seminário entre os grupos espanhóis na Universidade de Valência, a que se seguiu um outro Seminário em março de 2019, em Córdova, onde o Projeto se difundiu, realizando-se em abril de 2019 um novo encontro, de dimensão ibérica, na Ciudad Real. (SOUTO GONZÁLEZ; CLAUDINO, 2019, p. 10).

Loizaga (2019) apresenta um estudo do desenvolvimento do projeto em Valência, na Espanha. O referido autor levanta algumas considerações como a importância do apoio da Universidade de Valência-UV para a institucionalização e andamento do projeto, a relevância que ocupa a educação geográfica nas práticas pedagógicas dos professores participantes e que os estudos do entorno e da localidade possuem na aprendizagem dos alunos.

Segundo Loizaga $(2019, \text { p. 54) })^{55}$, “[... parece que la problematización y la conexión con los espacios próximos y su entorno, en la mayoría de los casos, supone un elemento motivador de primer orden". Para além disso, percebeu-se que ainda existe uma Escola Tradicional que exerce um tempo examinador e hegemônico frente às novas demandas educacionais e sociais da contemporaneidade.

Para evidenciar a concretude do projeto, apresentamos eventos científicos na península ibérica. No ano de 2017, um grupo de alunos e professores de Ciudad Real deslocou-se a Lisboa, ao IGOT, onde apresentaram as suas propostas, como também o fizeram alunos portugueses. Depois, alunos e professores do IGOT deslocaram-se para a Ciudad Real. Houve intervenções de professores sobre o Projeto e os alunos portugueses foram a escolas da Espanha, onde conviveram com seus professores.

Foi realizado, em março do ano de 2018, o I Encontro Municipal Internacional. Realizou-se em Valência, na Universidade de Valência (UV), no qual alunos da Escola Ontinyent, IES Font de S. Lluis/Valência apresentaram as propostas que elaboraram, bem como alunos de várias escolas de Ciudad Real, que para lá se deslocaram. Em abril do ano de 2019, ocorreu o II Encontro Municipal Internacional, alunos das Escolas Ontinyent e de Xàvia

\footnotetext{
$\overline{55}$ “[...] a problematização e a conexão com os espaços próximos e seu ambiente, na maioria dos casos, é um
} elemento motivador de primeira ordem" (tradução nossa). 
vieram a Ciudad Real. Participaram, ainda, alunos de Ciudad Real e Alcazar de S. Juan, que fica próximo de Ciudad Real. Houve conferências e apresentação de propostas, dentre outras atividades.

Em março do ano de 2020 foi realizado em Cascais o III Encontro municipal internacional $^{56}$, que contou com a apresentação de alunos, pais e professores na Universidade de Castilla La Mancha e representantes da Câmara Municipal. Vieram, também, alunos de Xávia-Javea/Valência. Foi feita uma sessão de apresentação de propostas por parte de alunos, de Ciudad Real e Javea, e também estava prevista a apresentação de portugueses (ASPEA, 2020). Essas ações mostram a concretude do projeto em Portugal e na Espanha, e o processo de municipalização em Portugal.

Figura 8 - Nós Propomos! países participantes

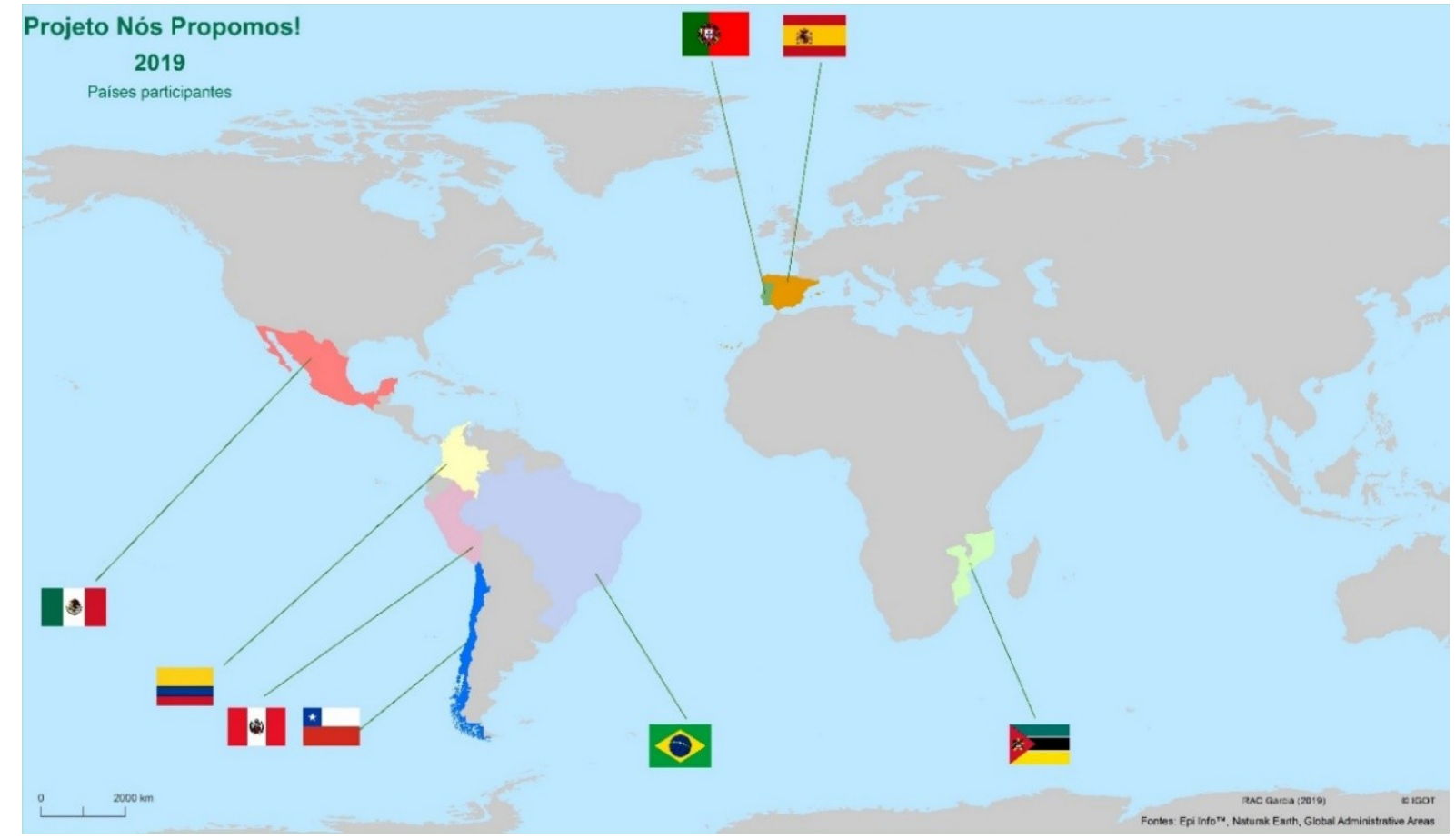

Fonte: Claudino (2019b, p. 377)

O projeto ultrapassou a esfera ibero-americana com o ingresso de representantes da Escola portuguesa ${ }^{57}$, na cidade de Maputo, em Moçambique, no continente africano. Atualmente, o projeto tem "alcance atlântico", sendo entendido como um projeto ${ }^{58}$ de ensino

\footnotetext{
${ }^{56}$ Para mais informações: https://www.cascais.pt/nos-propomos-cascais. Acesso em: 14 mar. 2020.

${ }^{57}$ Para mais informações http://www.epmcelp.edu.mz/index.php. Acesso em: 28 out. 2019.

58 É possível obter mais informações sobre o Projeto Nós Propomos! cidadania e inovação na educação geográfica pelos seguintes endereços eletrônicos: http://www.igot.ulisboa.pt/projeto-nos-propomos.; http://nospropomos2016.weebly.com/,http://nospropomos.blogspot.com/,https://falagrupoelo.blogspot.com/ 2018/02/i-congresso-iberoamericano-nos-popomos.html. Acesso em: 10 de julho de 2019.
} 
ibero-americano ${ }^{59}$. No Chile, o Projeto ainda não foi iniciado de fato, havendo a expectativa de que o seja.

No Brasil, o projeto é realizado em diversos estados e conta com a participação de cerca de vinte instituições públicas federais e estaduais de Ensino Superior, que, em parceria com as escolas de Educação Básica, buscam promover a formação cidadã dos estudantes.

Em 2014, o Projeto iniciou-se no estado de Santa Catarina, na Universidade Federal de Santa Catarina (UFSC). Em 2015, foi implantado no estado do Tocantins, na Universidade Federal do Tocantins (UFT). Em seguida, estendeu-se para vários estados brasileiros, entre eles, Rio Grande do Norte, Paraíba, Ceará, Goiás, Minas Gerais, Rio de Janeiro, São Paulo, Rio Grande do Sul, Paraná e Acre.

Em 2016, expandiu para o estado do Pará, e “[...] está em execução nas cidades de Bragança, Santarém e mais recentemente em Marabá, na UNIFESSPA (Universidade Federal do Sul e Sudeste do Pará), coordenado pelo o Prof. Dr. Marcus Vinicius Mariano de Souza, e foi desenvolvido através do Laboratório de Estudos Urbanos - LEURB” (PAIXÃO, 2019, p. $60)$.

Em 2017, no estado de Piauí, na Universidade Federal do Piauí (UFPI) e, respectivamente, no Distrito Federal (DF), na Universidade de Brasília (UNB). Nesta universidade, o Grupo de Pesquisa Ensino, Aprendizagem e Formação de Professores de Geografia (GEAF), sob a Coordenação da Professora Dr. ${ }^{\text {a }}$ Cristina Maria Costa Leite, publicou a obra “Ensinar e aprender Geografia por meio do projeto Nós Propomos!”. Tal obra apresenta práticas pedagógicas desenvolvidas em algumas Regiões Administrativas do Distrito Federal/DF. No mesmo ano, no estado de São Paulo, pela Universidade Estadual Paulista (UNESP) em Marília e em 2018, pela Universidade de São Paulo (USP), em Ribeirão Preto.

\footnotetext{
59 A ibero-américa ou América Ibérica é uma região do continente americano que compreende os países ou territórios onde o português ou espanhol são as línguas predominantes, geralmente antigos territórios do Império Português e Espanhol.
} 
Figura 9 - Panorama das instituições brasileiras que colaboram com o projeto Nós Propomos!

\begin{tabular}{|c|c|c|}
\hline REGIÃO & $\begin{array}{c}\text { ESTADOS } \\
\text { BRASILEIROS }\end{array}$ & INSTITUIÇÕES \\
\hline \multirow{3}{*}{$\begin{array}{l}\text { Centro- } \\
\text { Oeste }\end{array}$} & Distrito Federal & Universidade de Brasilia (UNB) \\
\hline & Goiás & Universidade Estadual de Goiás (UEG) \\
\hline & Mato Grosso & Universidade Federal do Mato Grosso (UFMT) \\
\hline \multirow{3}{*}{ Norte } & Acre & Instituto Federal do Acre (IFAC) \\
\hline & Pará & $\begin{array}{l}\text { Universidade Federal do Sul e Sudeste do Pará } \\
\text { (UNIFESSPA) }\end{array}$ \\
\hline & Tocantins & Universidade Federal do Tocantins (UFT) \\
\hline \multirow{7}{*}{ Nordeste } & Alagoas & Universidade Federal de Alagoas (UFAL) \\
\hline & \multirow{2}{*}{ Ceará } & Universidade Estadual do Ceará (UECE) \\
\hline & & Universidade Federal do Ceará (UFC) \\
\hline & Paraíba & Universidade Estadual da Paraíba (UEPB) \\
\hline & \multirow{2}{*}{ Piauí } & Universidade Federal do Piauí (UFPI) \\
\hline & & Instituto Federal do Piauí (IFPI) \\
\hline & Rio Grande do Norte & $\begin{array}{l}\text { Universidade do Estado do Rio Grande do Norte } \\
\text { (UERN) }\end{array}$ \\
\hline \multirow{5}{*}{ Sudeste } & Minas Gerais & Universidade Federal de Minas Gerais (UFMG) \\
\hline & \multirow{2}{*}{ São Paulo } & Universidade Estadual Paulista (UNESP) \\
\hline & & Universidade de São Paulo (USP) \\
\hline & \multirow{2}{*}{ Rio de Janeiro } & Universidade Estadual do Rio de Janeiro (UERJ) \\
\hline & & Universidade Federal Rural do Rio de Janeiro (UFRRJ) \\
\hline \multirow{5}{*}{ Sul } & Santa Catarina & Universidade Federal de Santa Catarina (UFSC) \\
\hline & \multirow[t]{2}{*}{ Paraná } & $\begin{array}{l}\text { Universidade Estadual do Oeste do Paraná } \\
\text { (UNIOESTE) }\end{array}$ \\
\hline & & Universidade Estadual do Centro Oeste (UNICENTRO) \\
\hline & \multirow{2}{*}{ Rio Grande do Sul } & Universidade Federal do Rio Grande do Sul (UFRGS) \\
\hline & & Universidade de Passo Fundo (UPF) \\
\hline
\end{tabular}

Fonte: Teixeira (2020, p. 64)

A figura 9 apresenta a presença do projeto na maioria dos estados brasileiros, são dezesseis estados, mais o Distrito Federal, contemplados com o projeto de um total de vinte e seis estados brasileiros. Notamos maior incidência do projeto realizado em Universidades Federais (11), seguida das Estaduais (9), seguida de Institutos Federais (2) e Universidades Privadas (1). Importante pontuar que, embora a figura 9 apresente as instituições algumas delas não realizaram nenhuma ação e/ ou produção referente ao projeto (TEIXEIRA, 2020).

No Brasil, o projeto foi viabilizado por meio do envolvimento de universidades e grupos de pesquisa e de extensão em parceria com escolas da Educação Básica. Os trabalhos são realizados em parcerias com professores da Educação Básica e dos grupos de estudo e de pesquisa. Podemos citar algumas dessas universidades e grupos como os seguintes:

[...] Grupo de Pesquisa ELO/Grupo de Estudos da Localidade, em Ribeirão Preto/São Paulo; o Grupo de Pesquisa, Ensino, Aprendizagem e Formação de Professores em Geografia da Universidade de Brasília (GEAF/UNB); o Grupo de Pesquisa Representações, Espaços, Tempos e Linguagens em Experiências Educativas/RETLEE, da Universidade Estadual do Oeste do 
Paraná/Francisco Beltrão; o Grupo de Pesquisa Cidade e Meio Ambiente/CNPq-Conselho Nacional de Desenvolvimento Científico e Tecnológico da Universidade Federal do Tocantins, em Palmas; Rede de Pesquisa em Ensino de Cidade da Universidade Federal de Goiás. (SOUTO GONZÁLEZ; CLAUDINO, 2019, p. 10).

Com base na figura 9 e no trecho anterior, observamos grande relação entre o papel das Universidades e dos Grupos de pesquisa como eixos dinamizadores do projeto para as escolas participantes, em todo o Brasil. Os professores participantes têm amparo e orientações em suas práticas por meio da ação dos grupos de pesquisa, presentes nas universidades parceiras do projeto.

Destacamos o estudo de Teixeira (2020), que aponta em suas considerações que o Projeto Nós Propomos! é desafiador e está em construção na ibero-américa e no Brasil; no entanto, apresenta alguns desafios como a ausência de um levantamento geral sobre as práticas, por meio de rede social e de dados oficiais. Assim, isso pode causar dispersão e fragmentação de comunicação e, ainda, não temos uma identidade e quantidade exata de participantes no Brasil para podermos avançar do ponto de vista teórico, conceitual e metodológico (TEIXEIRA, 2020).

Vários trabalhos já foram apresentados e publicados sobre o desenvolvimento do projeto em algumas localidades do Brasil. Trazemos aqui quatro deles para explicitar o caráter científico e a importância do referido projeto no que se refere à pesquisa, ao ensino e à extensão. Selecionamos práticas pedagógicas feitas no Distrito Federal (DF), no estado de Santa Catarina (SC) e no estado do Rio Grande do Sul (RS) como forma de amostragem. Destacamos três práticas pedagógicas publicadas e uma pesquisa de reflexão teórica. Essas publicações estão presentes em anais de evento científico, em periódico de circulação nacional e em forma de capítulos de livro.

A primeira refere-se à prática feita em uma escola particular do $9^{\circ}$ ano na Região Administrativa de Taguatinga, no Distrito Federal (DF). A prática consistiu em analisar a interpretação dos problemas urbanos de alunos do $9^{\circ}$ ano do Ensino Fundamental por meio do uso do aplicativo Google Earth.

Neste sentido, a ferramenta do Google Earth foi usado como instrumento de promoção da cidadania. A pesquisa da prática foi feita por meio da pesquisa-ação com entrevista aos alunos participantes. Segundo Luz Neto (2019, p. 11), temos como considerações que a prática de 
[...] mediação do Google Earth articulada a problemas urbanos locais das cidades do Distrito Federal promoveu o desenvolvimento dos alunos para a atuação cidadã crítico-reflexiva no processo de ensino/aprendizagem. Sem dúvida, os educandos perceberam que o lugar onde vivem é um espaço marcado por problemas, mas também relacionado a possibilidades de resolução.

A segunda prática ocorreu em duas escolas públicas estaduais, com alunos do $2^{\circ}$ ano do Ensino Médio, também na região administrativa de Taguatinga e em Asa Branca, no Distrito Federal. A prática teve como objetivo analisar e sintetizar o conteúdo de pôsteres científicos apresentados no ano de 2017 como forma de trabalho final relacionado ao projeto Nós Propomos!.

Suess (2019) apresenta-nos que os alunos despertaram para uma cidadania territorial e para uma autonomia intelectual, ao olharem de forma crítica os problemas de suas localidades. Segundo Suess (2019, p. 267), considerou-se que

Como evidenciado, diversas situações vividas pelos alunos foram identificadas e problematizadas e por meio do estudo de caso e da investigação científica os alunos tiveram o protagonismo de propor soluções [...] deve-se ressaltar que o projeto possui um grande potencial para ser aplicado em outras localidades, em especial no Distrito Federal, pois a sua essência é identificar problemas locais e propor soluções, não se restringindo a um espaço ou contexto específico.

A terceira prática analisa as práticas pedagógicas desenvolvidas no Centro de Ensino Médio Integrado da Universidade de Passo Fundo-UPF, no estado do Rio Grande do Sul-RS, junto com alunos de graduação e da Educação Básica, além disso verifica possibilidades de ampliação do projeto. O projeto inicia-se no segundo semestre de 2017 e continua ao final de 2019, sendo incorporado ao calendário escolar.

Gengnagel (2019, p. 90) aponta como considerações o fato que o Centro precisa avançar na interdisciplinaridade e destaca que "[...] compete aos protagonistas a tarefa de devolver à comunidade toda a experiência obtida com o desenvolvimento do projeto [...]”. Além disso, reafirma o compromisso do projeto para despertar os alunos para a localidade e para as intervenções possíveis na sua localidade.

A reflexão teórica apresenta os elementos teórico-geográficos do lugar e cotidiano em pesquisa, permeados da perspectiva de construção da cidadania territorial, feita na Universidade Federal da Fronteira Sul-UFFS, em Chapecó, no estado de Santa Catarina-SC. Neste sentido, destaca a importância do projeto para realizar investigações com foco no local, 
por meio das parcerias entre as universidades e as escolas. Os autores levantam como consideração que

\begin{abstract}
A maior intenção é, a partir do desenvolvimento da ciência, da pesquisa, do envolvimento entre graduandos, mestrandos e alunos do ensino médio, aproximação universidade e escola, academia e cidade, é promover e fortalecer a cidadania e assim, a sociedade local. [...] espera-se a construção da cidadania implicada territorialmente na aprendizagem do processo investigativo, e a integração entre graduação e pós-graduação na universidade, e destes com a escola. (GUIDO; ANDREIS, 2019, p. 295).
\end{abstract}

Desta forma, casos particulares de práticas desenvolvidas em contextos diferentes no Brasil se unem para demonstrar a força e presença do projeto como forma de contribuição de uma educação geográfica comprometida com o local e com a investigação e proposição de soluções para problemas do cotidiano dos alunos. Além disso, notamos a proximidade da relação entre universidade, extensão, ensino e comunidade escolar nas análises de despertar de um sujeito participando ativamente das decisões locais, por meio de escolas comprometidas com o saber.

Para que o projeto tenha conseguido alcançar essa dimensão ibero-americana, foi necessário o desenvolvimento de inúmeras parcerias para a criação de uma rede de colaboração entre universidades, escolas, professores da Educação Básica, gestores, professores pesquisadores e autarquias em um jogo de diálogos e trocas de informações, recursos materiais e de pessoas.

Figura 10 - Tempo de atuação do projeto nas cidades brasileiras 


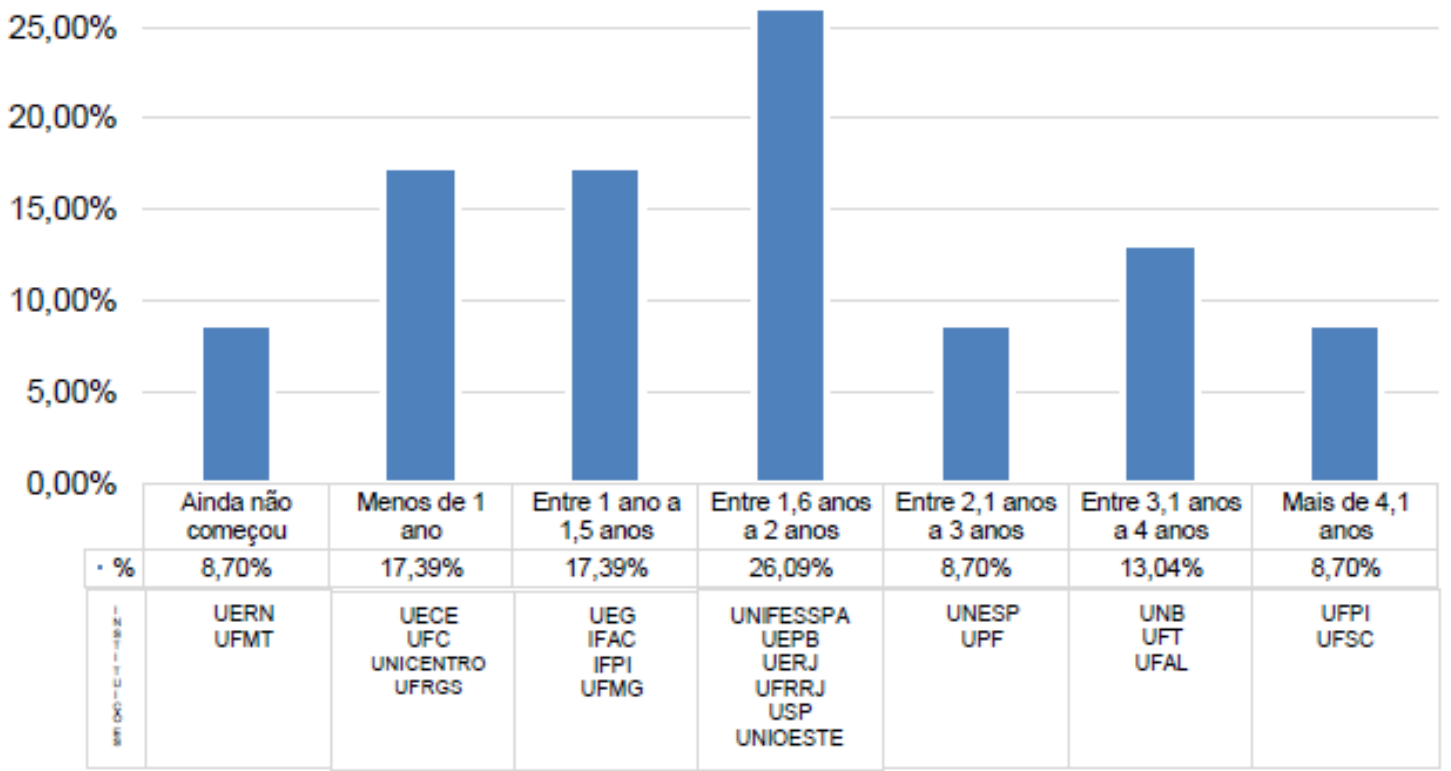

Fonte: Teixeira (2020, p. 65)

Notamos pelo gráfico explicitado (Figura 10) que a Universidade de São Paulo (USP) e a Universidade Estadual Paulista (UNESP) estão no grupo de instituições $(26,09 \%)$ paulistas que estão entre 1,6 e 2 anos de realização do projeto. Sinalizamos também que o projeto no Brasil iniciou-se em 2014 na Universidade Federal de Santa Catarina e na Universidade Federal do Piauí, e somente "[...] no ano de 2017 que o projeto teve maior expansão, onde cerca de $60 \%$ das instituições começaram a desenvolver o projeto, encabeçadas pela região sudeste, seguidas respectivamente pela região Norte e Nordeste" (TEIXEIRA, 2020, p. 66). 
Figura 11 - O "Projeto Nós Propomos! cidadania e inovação na educação geográfica” na América Latina

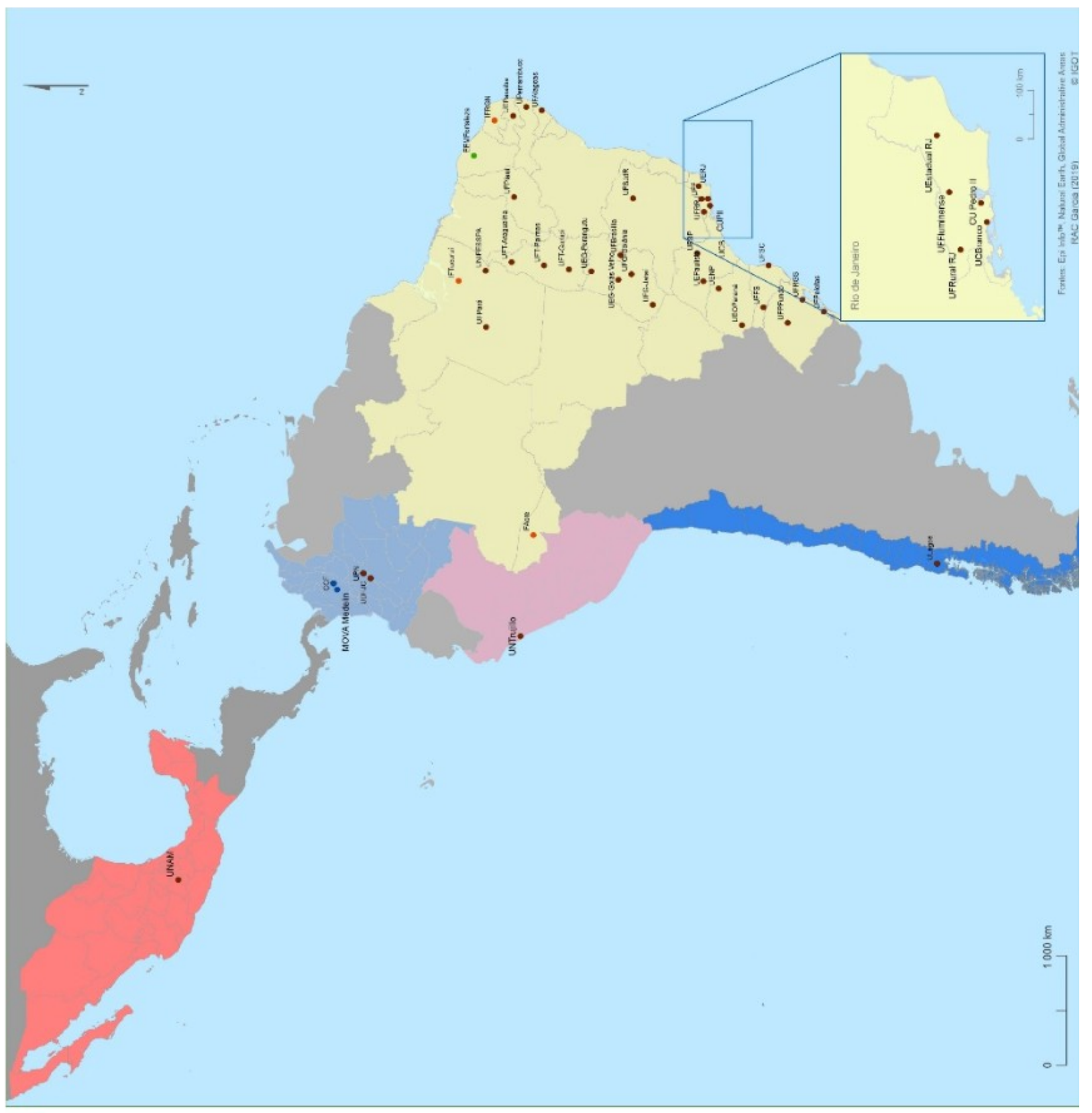

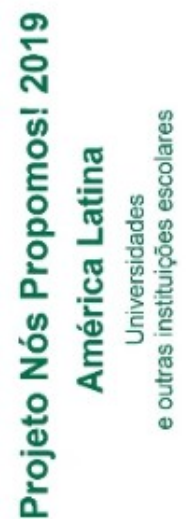

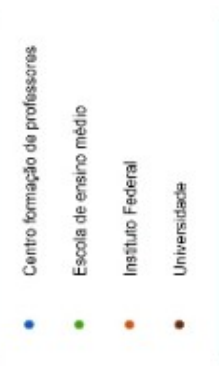

Fonte: informação pessoal ${ }^{60}$

${ }^{60}$ Enviado por Sérgio Claudino, autor do Projeto Nós Propomos!, no dia 04 de jan. 2020. 
Tanto em Portugal como no Brasil, salientamos uma complexidade de ações envolvidas para a realização do projeto a fim de atingir os objetivos de uma educação geográfica para a cidadania. Os alunos são o foco das ações desenvolvidas durante o ano letivo, podendo, ainda, avançar para o próximo ano, sem comprometimento das práticas pedagógicas. Neste sentido, as práticas pedagógicas desenvolvidas com o projeto são flexíveis, pois não é rígido, considera as realidades locais de onde será implementado (CARVALHO SOBRINHO, 2018).

Destacamos a importância que a Universidade assume como promotora das relações de parcerias entre as outras instituições. Concordamos com Silva (2000, p. 120) que "[...] a função social da universidade possa ser resumida no intuito de 'colaborar na integração social da maioria dos indivíduos". Neste sentido, a fala da professora participante Rosani é enriquecedora na medida em que traz um olhar de mediadora de dois professores que realizaram as práticas pedagógicas em Mococa-SP. Um olhar do Ensino Superior para a Educação Básica como forma de contribuir com a ampliação das percepções sobre as práticas de professores participantes do projeto Nós Propomos! $!^{61}$.

Quando a universidade prioriza somente um caminho, ou seja, a pesquisa ou o ensino, ou somente a extensão, afasta-se do tripé que deve sustentar todas as ações acadêmicas e, assim, acaba reduzindo seu potencial de abrangência social. O "Projeto Nós Propomos! cidadania e inovação na educação geográfica" tem caráter de pesquisa, ensino e extensão. Admitimos que a extensão universitária é fundamental para o desenvolvimento social das comunidades, pois

[...] se aproximam na prática do ideal não assistencialista, na qualidade de vias de mãos duplas produzem ganhos que são compartilhados entre os diversos segmentos envolvidos. Assim, esta característica de não mais estender conhecimento a uma população presumida enquanto objeto, mas de dialogar na construção de novos saberes no projeto é dilatada pelas visitas de campo e consultas à comunidade. Processo este capaz de validar os conhecimentos comunitários a partir do aporte científico da universidade e contribuir com a desconstrução da assimetria que demarca a relação sociedade-universidade, buscando o diálogo necessário entre estas e superando a hierarquização entre conhecimento científico e senso comum. (LEÃO, 2018, p. 38, grifo nosso).

As amplas relações de parceria por meio do tripé ensino-pesquisa-extensão evidenciam as ações produtivas do projeto. De modo geral, o "Projeto Nós Propomos!

\footnotetext{
${ }^{61}$ Destacamos o trabalho da professora Rosani intitulado "Projeto Nós Propomos! - Metodologia ativa em ação" publicado nos anais do $14^{\circ}$ Encontro Nacional de Prática de Ensino de Geografia: Políticas, Linguagens e Trajetórias. Disponível em: https://ocs.ige.unicamp.br/ojs/anais14enpeg/article/view/3119
} 
cidadania e inovação na educação geográfica" aborda 10 princípios, a saber: 1) Cidadania territorial; 2) Simplicidade metodológica; 3) Flexibilidade; 4) Investigação; 5) Construtivismo; 6) Diálogo/horizontalidade; 7) Parcerias; 8) Valorização de diferentes competências; 9) Multidisciplinaridade; 10) Divulgação (CLAUDINO, 2019a, 2019b). Desta forma, podemos notar que o projeto reforça a ideia da Escola como agente de transformação social ao colocar o aluno como sujeito ativo do saber e de práticas de cidadania.

O Projeto alinha-se a uma Geografia como elemento chave para o desvendar da complexidade do espaço e sua humanização é um dos pontos centrais da educação geográfica (MENDONÇA; CLAUDINO, 2016).

Figura 12 - Esquema de marcos legais de suporte ao "Projeto Nós Propomos! cidadania e inovação na educação geográfica" no estado do Tocantins/ Brasil

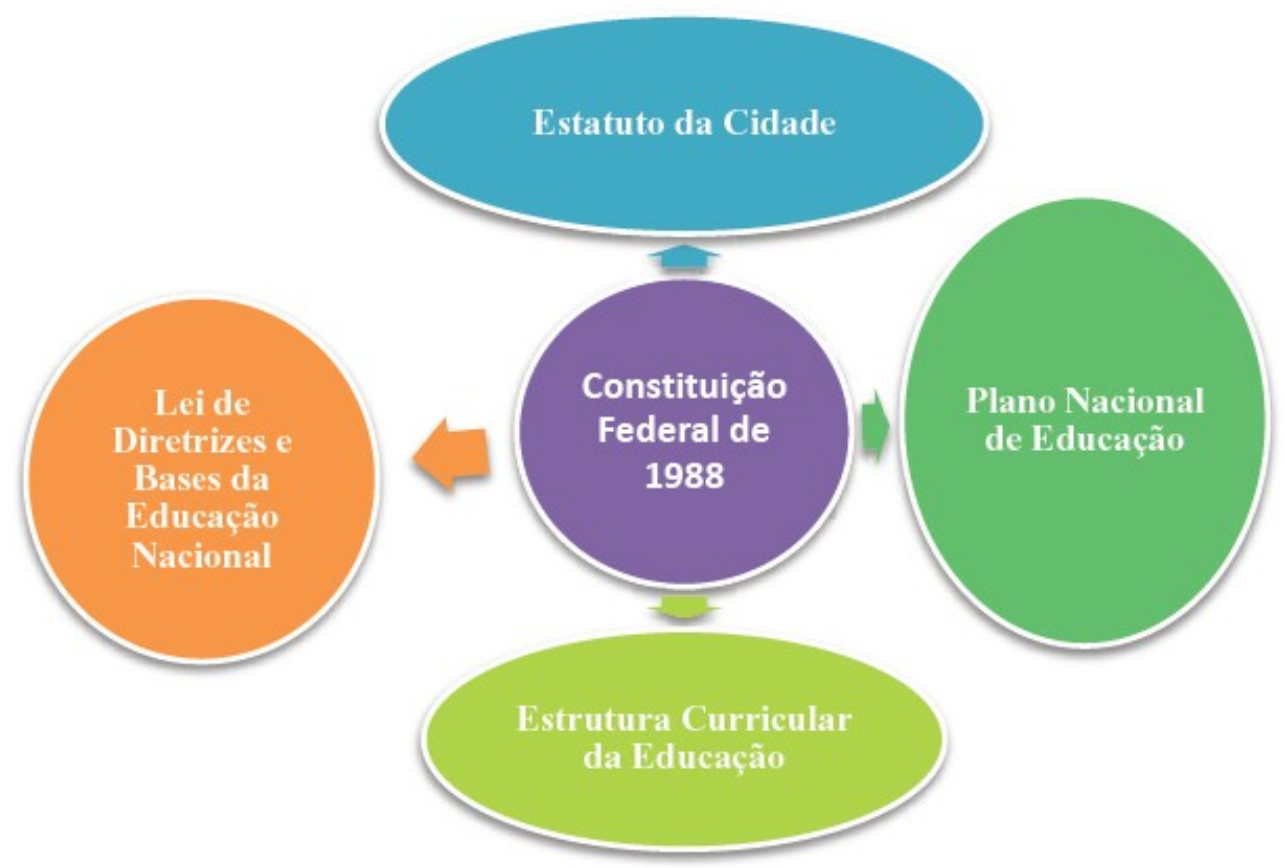

Fonte: (BAZOLLI; COSTA E SILVA;VIANA, 2017, p. 13)

Com base no que foi apresentado, discutido e no esquema (Figura 12) ${ }^{62}$ podemos considerar que o projeto adentra no estudo de documentos oficiais para permitir aos alunos práticas pedagógicas como instrumento ativo da cidadania. Embora o esquema retrate a realidade do projeto desenvolvido no estado do Tocantins, podemos inferir sobre a sua aplicação em outros estados brasileiros.

O projeto abrange o social e o político quando coloca a participação cidadã do estudante em pauta e provoca reflexões nos estudantes e professores das escolas envolvidas.

\footnotetext{
62 Este esquema refere-se especificamente ao desenvolvimento do projeto no estado do Tocantins. Coordenado
} pelo Prof. Dr. João Bazolli na Universidade Federal do Tocantins. 
Desta forma, alinhamo-nos ao pensamento de Santos (2004, p. 22) de que "[...] a cidadania, sem dúvida, se aprende”. Esta cidadania, então, pode ser construída por meio das práticas do projeto. Assim, a finalidade do "Projeto Nós Propomos! cidadania e inovação na educação geográfica" é

[...] elaborar propostas fundamentadas de resoluções de problemas urbanos e socializá-los em 12 Seminários e nas instâncias comunitárias, com o intuito de provocar reflexões sobre as questões locais numa perspectiva interdisciplinar. Também procura sedimentar, pelas atividades propostas, a experiência da participação popular e da cidadania ativa. (BAZOLLI et al., 2017, p. 97).

Além dos elementos mencionados, destacamos, novamente, a importância do cotidiano e da localidade nas ações educativas e como fator fundamental da constituição dos sujeitos na instituição escolar. O trabalho na vida cotidiana

[...] é a vida de todo homem. Todos a vivem, sem nenhuma exceção, qualquer que seja seu posto na divisão do trabalho intelectual e físico. Ninguém consegue identificar-se com a vida genérica a ponto de desligar-se inteiramente da vida cotidianidade, embora este 0 absorva preponderantemente. A vida cotidiana é a vida do homem inteiro; ou seja, o homem participa na vida cotidiana com todos os aspectos da sua individualidade, de sua personalidade. (HELLER, 1999, p. 17).

As práticas desenvolvidas por meio do "Projeto Nós Propomos! cidadania e inovação na educação geográfica" podem revelar ações diferenciadas e não tradicionais de ensino. Esse projeto responde aos vários questionamentos e inquietações por um ensino de Geografia crítico, focado no aluno como agente transformador da sociedade e da sua comunidade ${ }^{63}$.

Por meio desse projeto, o ensino de Geografia pode promover o envolvimento do estudante com o seu local de vivência, o que permite uma maior participação cidadã. Deste modo, podemos afirmar que o projeto abarca os seguintes objetivos, no que envolve o aluno:

I) promover uma ativa cidadania territorial junto da comunidade escolar;

II) aproximar o poder local (Câmaras, Juntas de Freguesia) das comunidades, através da participação dos jovens e das suas escolas;

III) contribuir para um desenvolvimento sustentável das localidades e dos municípios onde se desenvolve;

IV) valorizar o Estudo de Caso, quando contemplado no Programa, como trabalho experimental sobre problemas locais;

V) promover abordagens metodológicas inovadoras no âmbito do ensino da Geografia;

VI) incentivar a atividade de investigação em Geografia;

${ }_{63}$ O referido projeto busca pensar local e global dentro da educação geográfica cidadã (MENDONÇA; CLAUDINO, 2016). 
VII) mobilizar alunos e professores para a utilização de tecnologias de informação, em estudos de âmbito prático;

VIII) fomentar redes de cooperação entre atores locais, como universidades, escolas, autarquias, associações locais e empresas. (IGOT, 2018/2019).

Notamos que os objetivos apresentados se alinham, de forma constante, com os componentes de uma formação cidadã em que se tem a participação, pesquisa, cooperação, a localidade como pontos fortes das operações feitas pelos alunos e professores, no âmbito científico e escolar. Destaque especial para os itens I e IV que contribuem para a promoção do estudo local e levantamento dos seus problemas, para que, no item II, estes problemas sejam compartilhados com o Estado, por meio de participação efetiva dos estudantes.

O estudo de caso, desenvolvido no projeto no objetivo IV, apresenta-se como uma estratégia focada em uma situação particular/individualizada que "[...] representa a estratégia preferida quando se colocam questões do tipo 'como' e 'por que', quando o pesquisador tem pouco controle sobre os eventos e quando o foco se encontra em fenômenos contemporâneos inseridos em algum contexto da vida real". (YIN, 2001, p. 19).

Esse "contexto da vida real”, mencionado por Yin (2019), é a força da presença do local nas análises dos alunos e do professor. Assim, a localidade e suas problemáticas sociais tornam-se o ponto de partida para a análise e proposição de soluções pelos alunos. Nesse sentido, ao analisar os problemas da vida real e tentar entender a complexidade dos fenômenos sociais e as mudanças ocorridas nas regiões urbanas, por meio de conhecimentos científicos e escolares, o estudo de caso contribui para a educação geográfica voltada à cidadania.

O projeto Nós Propomos! também promove práticas como o estudo do meio, o levantamento de problemas locais e de questionamentos do cotidiano pelo aluno-cidadão. Assim, concordamos com Bazolli et al. (2017, p. 105) que o “[...] 'Projeto Nós Propomos! cidadania e inovação na educação geográfica' visa a incitar e estimular os alunos à construção da cidadania e ao exercício da autonomia, além de provocar o estudo independente, que tem sua essência no aprender a aprender [...]". Destacamos que o estudo do meio pode ser entendido como ação vinculada pelo trabalho de campo, com foco em determinada localidade.

No Brasil, no estado do Tocantins, o Professor Dr. João Bazolli elaborou um manual para facilitar a implantação do projeto, tanto em municípios do referido estado quanto em outras localidades. Neste país, o projeto também tem uma metodologia de implantação e desenvolvimento de seu funcionamento nas escolas, por meio de parcerias e constantes 
diálogos entre universidades, comunidade escolar e o poder público. O autor enumera dez passos, que são:

$1^{\circ}$ Contato com as escolas, sensibilização e apresentação do projeto; $2^{\circ}$ Manifestação de interesse da escola em participar das atividades e ações do projeto; $3^{\circ}$ Formação de grupos colaborativos de trabalho para 0 desenvolvimento do projeto; $4^{\circ}$ Atividades técnicas, nivelamento $\mathrm{e}$ qualificação; $5^{\circ}$ Desenvolvimento do projeto; $6^{\circ}$ Pesquisa documental e revisão de literatura; $7^{\circ}$ Trabalho de campo e outras técnicas de pesquisa; $8^{\circ}$ Como resolver o problema estudado; $9^{\circ}$ Como desenvolver e finalizar o trabalho; e $10^{\circ}$ Socialização no seminário anual (BAZOLLI; COSTA E SILVA, VIANA., 2017, grifo nosso).

Para tanto, destacamos que cada localidade pode fazer adaptações à sua realidade local e apresentar encaminhamentos em diferentes ritmos e modos de ação para o desenvolvimento do projeto. Nesse sentido, podemos perceber que a educação geográfica, discutida anteriormente, está presente no projeto e se materializa no corpo das ações propostas pelos alunos. Desse modo, a educação geográfica deve construir uma “[...] prática que contribua para a evolução conceitual do aluno, atuaremos na perspectiva da construção do conhecimento, refletindo sobre a realidade vivida pelo aluno, respeitando a sua história de vida e contribuindo para que ele entenda o seu papel na sociedade: o de cidadão" (CASTELLAR, 2005, p. 222).

O projeto possibilita um ensino de Geografia que, por meio de atividades, promove o protagonismo juvenil e o estudo da localidade. Desta forma, a capacidade de observação, do mais simples ao mais complexo, pode ser estimulada no espaço geográfico (BOSCOLO, 2007).

Para desenvolver o projeto, é necessário seguir alguns procedimentos que estão descritos no manual do projeto (BAZOLLI; COSTA E SILVA; VIANA., 2017) e estão permeados por conceitos fundamentais da educação geográfica. Esses conceitos não estão explícitos nos documentos do projeto, mas podemos notar a sua presença nos artigos e práticas pedagógicas e, a partir disso, elaborar nossa reflexão.

O primeiro conceito chave que abordamos é o lugar, presente como ideia valorativa nas referências do projeto e nos desdobramentos de suas ações. Segundo Carlos (1996, p. 20),

O lugar é a base da reprodução da vida e pode ser analisado pela tríade habitante-identidade-lugar. A vida se refere no local. As relações que os indivíduos mantêm com os espaços habitados se exprimem todos os dias nos modos de uso, condições banais. É o espaço passível ser sentido, pensado, apropriado e vivido através do corpo. 
Podemos notar no referido trecho que o lugar está intrinsecamente ligado à identidade dos habitantes e às suas vivências cotidianas com essa categoria do Espaço geográfico. Alinhado à ideia anterior, temos que o lugar “[...] não é apenas um quadro de vida, mas um espaço assumido como 'dimensão do social' que é de natureza coletiva, intrincado com o tempo vivido, de experiência sempre renovada" (SANTOS, 2010, p. 114). O lugar é constituído, essencialmente, das vivências e saberes de um coletivo que o apropria de modos distintos ao longo do tempo.

Isto posto, destacamos que é nele que há a reprodução que os alunos participantes do projeto analisam, pesquisam e refletem como forma do seu espaço e da sua vida. A vivência do cotidiano e do lugar é imprescindível para o projeto, que faz o jovem lançar “[...] múltiplos olhares sobre o espaço vivido, o discernimento de aonde pretendem chegar, a maneira contundente de apresentar o problema e, especialmente, a visão futura e sustentável de propor suas resoluções.” (BAZOLLI et al., 2017, p. 25). Essa projeção sobre o lugar do estudante é encontrada nos aportes teóricos sobre a educação geográfica e discutida por alguns teóricos do ensino de Geografia.

Desta forma, “[...] os jovens fazem parte do processo de reprodução do espaço urbano, pois em seu cotidiano participam dos fluxos, dos deslocamentos, da construção de 'próteses' cotidianas no espaço, da produção de territórios" (CALLAI, 2011, p. 47). Os alunos participantes do "Projeto Nós Propomos! cidadania e inovação na educação geográfica" configuram-se como atores reais das mudanças nos seus lugares, nas suas localidades, de forma intensa e produtiva como é mostrado na produção e nas ações do projeto em Portugal ${ }^{64}$ e no Brasil ${ }^{65}$.

Essa cidadania ativa desenvolvida por meio de práticas pedagógicas também é pensada na educação geográfica, na qual se constrói com a competência de fazer a leitura da cidade (CAVALCANTI, 2010). Esta leitura pode ser feita, primordialmente, a partir do lugar de vivência e das dinâmicas sociais dos alunos. Neste sentido, podemos citar o estudos de Paixão (2019), Rozin (2019) e Hrchorovitch (2019) que destacam as potencialidades do estudo do lugar como uma das contribuições das práticas do projeto Nós Propomos!. Segundo Paixão (2019, p. 74), houve

\footnotetext{
${ }^{64}$ Acompanhar as práticas nas escolas portuguesas e os detalhes do projeto por meio de um acervo fotográfico, por meio do site: http://nospropomos2016.weebly.com/. Acesso em: 05 de jun. 2019

${ }_{65}$ Tomamos como uma das referências no Brasil o projeto desenvolvido no estado do Tocantins que está em fase avançada de desenvolvimento. Para maiores informações consultar http://nospropomos.blogspot.com/. Acesso em: 05 de jun. 2019
} 
[...] inteiração e experiencias vivenciadas pelos alunos ao longo do projeto, permitiram aos mesmos olhar para o espaço onde vive com uma visão crítica, se colocando no papel de cidadão atuante perante a sociedade, $o$ resultado mais satisfatório foi vivenciar o crescimento educacional de pesquisador e de alunos comprometidos com o projeto, sempre pondo a sua comunidade no bojo das discussões, sempre contribuindo da melhor forma possível quando solicitado.

Nesta mesma linha de pensamento, destacamos que, embora fundamental, a dificuldade de "[...] trabalharmos com o lugar, especificamente a cidade, percebemos que não é um conteúdo trabalhado corriqueiramente, que é visto por muitos estudantes como algo alheio à sua realidade" (HRCHOROVITCH, 2019, p. 133). Por meio do projeto houve a ampliação da significação e importância do lugar para os alunos, com ênfase em práticas para a cidadania, com a problematização dos problemas locais e possíveis proposição para minimização dos mesmos (HRCHOROVICH, 2019).

Segundo Rozin (2019, p. 104) com as ações do projeto Nós Propomos! “[...] os estudantes perceberam que o lugar não é uma categoria abstrata, mas produto da atividade humana, na repetição dos atos, a própria evolução". Desta forma, houve uma aprendizagem para fora do espaço escolar, uma apreensão e compreensão dos lugares e do cotidiano pelos alunos (ROZIN, 2019).

Assim, admitimos que o projeto pode trabalhar de forma significativa com a categoria de lugar

[...] onde estão os princípios étnicos-sociais e os fatores econômicos, os políticos e os culturais que influenciam a educação geográfica. Para a compreensão deste contexto é necessário o uso apropriado dos signos para que ocorra comunicação, possível pelo aprendizado. (TAZINASSO; FRANCISCHETT, 2019, p. 2).

A teoria concretiza-se nas práticas do projeto, pois, segundo Bazolli et al. (2017, p. 42), “[...] o projeto pretendeu familiarizar os jovens estudantes com o poder local, sensibilizálos para as questões territoriais locais, motivá-los para a elaboração e apresentação de propostas de intervenção local [...]". Portanto, o projeto contribui para o empoderamento da população juvenil/estudantes quanto ao entendimento do seu lugar como forma de exercer a cidadania e a participação constante para o melhoramento da sua rua, bairro, campo ou cidade. Essa preocupação com o lugar pode ser observada nas práticas pedagógicas e nas pesquisas realizadas com relação ao projeto.

O projeto permite desenvolver, nos jovens, as práticas da experiência democrática por meio de sua participação social, outro conceito chave, nos assuntos políticos e sociais locais. 
A democracia, então, almeja a participação de todos no processo de construção das instituições, e inclui, assim, os estudantes como agentes participativos. Podemos assinalar que a participação cidadã é marca da nossa democracia e está prevista na Constituição Federal (1988) no Art. 5 , inciso LXXIII “[...] qualquer cidadão é parte legítima para propor ação popular que vise anular ato lesivo ao patrimônio público $[\ldots]$ ”.

Desta forma, podemos relacionar o "Projeto Nós Propomos! cidadania e inovação na educação geográfica" a uma constante interlocução com o poder local ao demandar e desenvolver ações participativas dos estudantes nas esferas públicas locais, por meio de pesquisas e resolução de problemas coletivos nas cidades.

Portanto, o conceito de participação social é " [...] a tomada de decisão coletivamente por grupos sociais que permitem que os sujeitos façam parte das ações que lhes dizem respeito nos aspectos políticos, sociais, culturais ou econômicos" (ALVES, 2013, p. 25). Para além disso, essa participação representa o anseio da população por integrar processos de tomada de decisões levando diretamente ao governo suas demandas (SIMÕES; SIMÕES, 2015).

Assim, notamos a importância do envolvimento dos indivíduos com a gestão pública para (re) construir os territórios como forma de promoção do bem-estar coletivo e público nas cidades. Nesse sentido, o "Projeto Nós Propomos! cidadania e inovação na educação geográfica" busca

[...] antecipar a participação popular formal e institucional e quer preparar os jovens para essa nova prática cidadã de maneira diferente, por esse motivo não pretende substancialmente mostrar problemas, mas apresentar propostas de resoluções [...] pretende-se promover a cidadania ativa e promover uma discussão com a comunidade, para que em processo participativo, sejam apresentadas as resoluções viáveis. (BAZOLLI et al., 2017, p. 76).

Essas soluções propostas devem contar com respaldo do poder público, por meio da participação social dos estudantes envolvidos no projeto. É por meio da prática da cidadania e seu exercício pleno que transformamos direitos formais em direitos reais (CAVALCANTI, 2010, p. 85).

Partindo dessa afirmação teórica, podemos deduzir que o "Projeto Nós Propomos! Cidadania e inovação na educação geográfica" constrói bases fundamentais para redimensionar embasamentos teóricos, debatidos no ambiente acadêmico, em aportes práticos e reais nas unidades escolares de diversas localidades nas quais o projeto se desenvolve. 
Em um contexto de democracia com amplas formas de manifestação da cidadania, o estudante torna-se protagonista para aprender as várias formas de participação social. Essa participação auxilia o estudante a pensar como é a organização da cidade e do seu espaço vivido frente a uma organização desigual e plural que atende a poucos indivíduos. Assim, consideramos como protagonismo dos jovens a contribuição trazida por Costa (2001, p. 179) de que é

[...] a criação de espaços e condições capazes de possibilitar aos jovens envolver-se em atividades direcionadas à solução de problemas reais, atuando como fonte de iniciativa, liberdade e compromisso [...] é a participação ativa e construtiva do jovem na vida da Escola, da comunidade ou da sociedade mais ampla.

Notamos que o projeto Nós Propomos! alinha-se a essa ideia de protagonismo juvenil, na medida em que possibilita aos alunos participantes desenvolver conhecimentos pertinentes à sua realidade e local e, assim, podem intervir no sentido de detecção e proposição de problemas reais vividos em seu cotidiano.

Isto posto, nas investigações no Brasil o conceito mais frequentemente empregado é o de Justiça socioespacial, que relaciona-se com a forma pela qual o governo gere as cidades, com os problemas de distribuição de riquezas, com a resiliência e resistência das populações às desigualdades, com as questões de opressão nos espaços públicos, com dimensões do espaço urbano enquanto “[...] percebido, concebido e vivido." (CARLOS; ALVES; PADUA, 2017, p. 128).

Para entendermos o referido conceito e sua relação com o projeto, é necessário relacionar a ligação direta com o modo pelo qual a população constrói e se apropria do espaço urbano, como vivido em privação, enfocando o direito à cidade como o negativo da metrópole no cotidiano com a participação social ativa da população na luta por melhor qualidade de vida local (CARLOS; ALVES; PADUA, 2017).

Portanto, podemos pensar esse conceito na dimensão política da sua aplicação, ou não, em forma de políticas públicas para os menos favorecidos dentro do sistema capitalista. $\mathrm{O}$ termo está ligado à luta pelo espaço público de forma ordenada e justa para o coletivo. Destacamos que não é pretensão desta investigação fazer uma reflexão sobre a cidade, os seus direitos e discussão sobre os espaços públicos. O "Direito à cidade" repousa em uma fundamentação teórica construída por Henri Lefebvre (CARLOS; ALVEZ; PADUA, 2017, p. $11)$. 
Já o projeto Nós Propomos! vislumbra a ideia de cidadania territorial local, (CLAUDINO, 2014), (CLAUDINO, 2018a, 2018b), (CLAUDINO, 2019a, 2019b), (CLAUDINO et al., 2019) que tem como objetivo promover um despertar da consciência de uma justiça social aplicada ao espaço urbano por meio do levantamento dos problemas locais, através da pesquisa de forma crítica e mediada com o professor, e a proposição de ideias para serem apresentadas ao poder público local.

O referido conceito é explicitado, inclusive, no regulamento de atividades do projeto, na página do Instituto de Geografia e Ordenamento do Território (IGOT) ${ }^{66}$, como um de seus objetivos o de "promover ativa cidadania territorial junto à população estudantil; aproximar o poder público local da comunidade por meio das escolas [...]” (IGOT-UL, 2019, n. p., grifo nosso).

Neste sentido, o uso do termo 'territorial' pode “[...] estar diretamente relacionado com a apropriação, transformação e identificação das comunidades com o território em que habitam" (CLAUDINO, 2014, p. 5), um território apropriado, de poder, com rugosidades evidenciadas pelas comunidades que aí habitaram e habitam (CALLAI, 2011). Percebemos que o território tem estreita ligação com vivência, com o cotidiano e com as apropriações e (re) apropriações que seus habitantes fazem dele e com ele. Desta forma, os alunos

[...] são sensibilizados para a reflexão em torno dos problemas locais e do seu papel na resolução dos mesmos, constituindo um inquérito individual, frequentemente, um instrumento promotor desta reflexão. [...] Estes prendem-se, frequentemente, com a construção de espaços de lazer e desporto, a recuperação de imóveis abandonados para fins públicos ou a melhoria dos transportes públicos e acessibilidades. (CLAUDINO, 2014, p. $6)$.

Assim, por meio do desenvolvimento do projeto pode existir a promoção de uma atuação cidadã qualificada (BAZOLLI, COSTA E SILVA, VIANA, 2017). Nesse sentido, podemos perceber elementos da justiça social aplicados ao conceito de cidadania territorial local. Essas semelhanças no entendimento dos conceitos apresentados podem garantir o uso, mesmo de forma não explícita, do termo 'justiça socioespacial' nas práticas do "Projeto Nós Propomos! cidadania e inovação na educação geográfica” no Brasil.

Portanto, entendemos que o conceito que mais se aproxima da nossa linha de pensamento e das práticas pedagógicas realizadas no estado de São Paulo, no Brasil, é o de cidadania territorial local.

\footnotetext{
66 É possível obter mais informações pelo endereço: http://www.igot.ulisboa.pt/wp content/uploads/2018/07/Regulamento-Projeto-N\%C3\%B3s-Propomos-2018 19.pdf.
} 
Com base nas reflexões apresentadas, elaboramos a figura 13 como uma síntese dos embasamentos que o projeto permite pensar ao ser aplicado nas distintas localidades em que vem sendo desenvolvido. 
Figura 13 - Esquema das contribuições teóricas para as ações do "Projeto Nós Propomos! cidadania e inovação na educação geográfica"

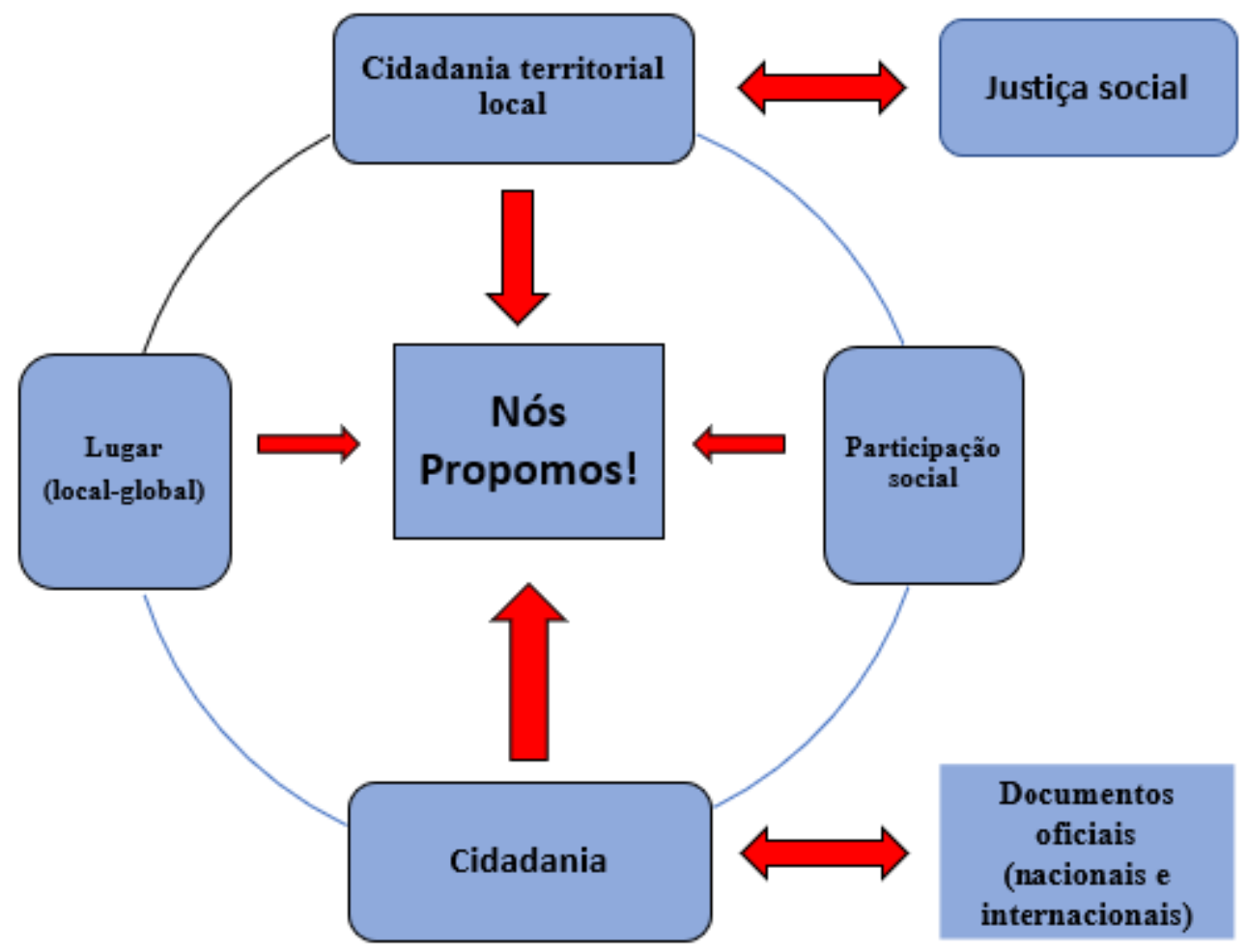

Fonte: elaborado pelo autor

Com base no esquema anterior, podemos perceber que o "Projeto Nós Propomos! cidadania e inovação na educação geográfica" agrega conceitos teóricos que se relacionam para (re) criar as práticas pedagógicas de Geografia (não tradicionais) e aprendizagens significativas aos alunos. Essas práticas envolvem o viver, o perceber e o pensar na educação geográfica para a cidadania.

Os conceitos chaves, que gravitam em torno do projeto, enriquecem a construção do conhecimento e o repertório dos alunos participantes do projeto, na medida em que os instrumentaliza para ler o mundo de forma científica e crítica, por meio de sua participação ativa e da intervenção na sua localidade. A cidadania é valorizada por meio de documentos nacionais e internacionais que reforçam as reflexões e as práticas do projeto. A justiça social é componente da cidadania territorial local em relações constantes para a construção do projeto.

O "Projeto Nós Propomos!, sob nossa ótica, apresenta uma contribuição significativa para o ensino de Geografia que se propõe aliado ao desenvolvimento da cidadania e por meio de práticas inovadoras aos estudantes e aos professores. Ambos aprendem, de forma significativa, por meio do levantamento de problemas com base em pesquisas da localidade. 
[...] de perspectiva de estudante receptor de informações para estudante investigador e autor, possibilita uma aproximação às questões sócioespaciais relevantes para a sociedade, considerando que a investigação implica em saídas de campo e exercício de todas as etapas de pesquisa. (MENDONÇA; CLAUDINO, 2016, p. 4).

Nesta perspectiva, tendo o aluno como protagonista ou sujeito do processo de aprendizagem, o ensino de Geografia reconfigura-se em termos formativos, assumindo uma efetiva preocupação cidadã e valorizando o espaço público local como potencial formativo (MENDONÇA; CLAUDINO, 2016).

Podemos constatar, por meio de uma reflexão teórica aliada à revisão bibliográfica de ações do projeto, que cada vez mais o referido projeto procura alinhar as demandas de resistência de uma sociedade globalizada e multifacetada (SANTOS, 2004) para uma visão mais humana e fraterna de sociedade.

Nessa sociedade, o cidadão tem responsabilidade sobre o local-global e uma cidadania mediada pela participação social, com aplicação da justiça espacial em um protagonismo juvenil eficaz. Isto posto, segundo o Manual do projeto (BAZOLLI; COSTA E SILVA, VIANA., 2017, p. 35), ao final do desenvolvimento do mesmo espera-se

[...] instigar os jovens estudantes a conhecerem a história da cidade, vai além do simples debate acerca do planejamento urbano, pois é também o de produzir uma massa crítica que fomente a longo prazo o seu interesse em participar nas decisões locais, e para isto, o conteúdo discutido pelo Projeto perpassa pelo Estatuto da Cidade e pelo Plano Diretor Municipal.

O estudo crítico e a intervenção na localidade destacam-se como pano de fundo das ações cidadãs por meio da participação ativa no desenvolvimento do projeto. $\mathrm{O}$ ensino de Geografia sofre uma ruptura, de um modo tradicional com um aluno passivo do saber e do conhecimento, para um modo inovador com um aluno com ações decisórias.

\subsection{Marcos do desenvolvimento do Projeto}

As investigações sobre o Projeto estão sendo feitas para consolidá-lo na ibero-américa. Cabe destacar três marcos para o projeto assumir caráter científico de alta relevância para além das obras já publicadas sobre o projeto. O primeiro marco é a criação de um espaço de reflexões e discussão sobre o projeto no Fórum Ibero-americano sobre educação, geografia e sociedade - GEOFORO ${ }^{67}$.

\footnotetext{
${ }^{67}$ Para mais informações: http://geoforo.blogspot.com/. Acesso em: 02 de março 2020.
} 
O GEOFORO, fundado em 2008, constitui-se como um fórum virtual iberoamericano, em língua espanhola e portuguesa, de debates entre alunos de graduação, pósgraduação, professores e pesquisadores de diversos países da América Latina e ibero-américa. Além disso, busca ampliar o intercâmbio de ideias e a produção científica sobre educação geográfica e cidadania. Fazem parte da equipe diretora professores universitários e pósgraduandos de instituições presentes na ibero-américa ${ }^{68}$. A página inicial do site estabelece os seguintes apontamentos:

El Foro Iberoamericano sobre educación, geografia y sociedad [...] trata de ofrecer aqui algunos resultados $y$, sobre todo, estimular a otras personas a reflexionar criticamente sobre la enseñanza de los problemas sociales y ambientales. [...] El sentido del foro sería definir qué podemos aportar a la comunidad escolar en la definición de la educación como derecho social reconocido en la Declaración Universal de 1948 e interpretado de muy diferente manera por los gobiernos, profesores y academias. Se trata de estimular la ciudadanía participativa desde una opinión crítica. También se difundirán experiencias didácticas y recursos educativos que han sido utilizados con éxito por parte del profesorado de distintos niveles de enseñanza, en especial de Secundaria. (GEOFORO, 2008) ${ }^{69}$.

Notamos uma ênfase nos debates em torno da Educação e do ensino por uma perspectiva crítica, focada nos problemas sociais e ambientais. Um espaço de aprendizagens entre os pares e que tem como foco o desenvolvimento de uma cidadania ativa, baseada nos princípios dos Direitos Humanos. Destacamos que desde o ano de 2010 é publicado ao final de todo ano um balanço geral das postagens e contribuições feitas pelos seus participantes na revista eletrônica Biblio3W, da Universidade de Barcelona/ Espanha ${ }^{70}$.

Nesse sentido, o GEOFORO possibilitou a investigação entre grupos de diferentes países para obter resultados que permitiram estabelecer comparações. Com isso, tornou-se evidente a existência de estratégias globais para o desenvolvimento da cultura escolar (FITA ESTEVE; CLAUDINO; SOUTO GONZÁLEZ, 2018).

Figura 14 - Produções acadêmicas do GEOFORO de 2010 a 2018

\footnotetext{
68 Para mais informações sobre o comitê diretivo do GEOFORO, acessar o referido site e entrar no item "nosotros".

69 "O fórum Ibero-americano sobre Educação, Geografia e Sociedade [...] visa aqui a alguns resultados e, sobretudo, estimular as outras pessoas a refletir criticamente sobre o ensino dos problemas sociais e ambientais [...] O sentido do fórum é definir que podemos contribuir para a comunidade escolar na definição de Educação como direito social reconhecido pela Declaração Universal de 1948 e interpretada de diferentes maneiras por governos, professores e a academia. Trata-se de estimular a cidadania participativa por uma opinião crítica. Também se difundirá experiências didáticas e recursos educativos que serão utilizados com êxito por parte dos professores de diferentes níveis de ensino, em especial do secundário" (tradução nossa).

70 Para mais informações: http://www.ub.edu/geocrit/bw-idg.htm. Acesso em: 28 de fev. de 2020.
} 


\begin{tabular}{|l|l|l|}
\hline Balances anuales & Síntesis de debates & Otros artículos \\
\hline Souto, Claudino y García, 2010 & Araya, 2009 & Martín y García, 2009 \\
\hline Souto y Durán, 2011 & Durán, 2012 & Souto, Moreno y Lastoria, 2012 \\
\hline Souto y Fita, 2012 & Santiago, 2012 & Souto, 2012 \\
\hline Souto y Fita, 2013 & Sousa, García y Souto, 2016 & Álvarez, Vásquez y Rodríguez, 2016 \\
\hline Souto y Fita, 2014 & Palacios y Ramiro, 2017 & Campo, Rodríguez y Colomer, 2016 \\
\hline $\begin{array}{l}\text { Campo, García, Rodríguez y Souto, } \\
2015\end{array}$ & & Araya, Souto y Claudino, 2018 \\
\hline Colomer, García y Palacios, 2016 & & Claudino, Souto y Araya, 2018 \\
\hline Catalá Colomer y Souto, 2017 & & García de la Vega et al., 2018 \\
\hline
\end{tabular}

Fonte: (FITA ESTEVE; CLAUDINO; SOUTO GONZÁLEZ, 2018, p. 3)

A figura 14 apresenta uma síntese das produções acadêmicas em torno das postagens e participações do GEOFORO como fonte de investigação. Desta forma, comprovamos a relevância desse espaço como produção e debate do conhecimento científico em torno de uma educação geográfica comprometida com os problemas globais e locais.

No GEOFORO, foi aberto no dia 30 de março, do ano de 2018, um fórum específico para compartilhamento de experiências do "Projeto Nós Propomos! cidadania e inovação na educação geográfica", no qual são apresentados dados, aspectos teóricos e práticas do referido projeto. O referido fórum chama-se "foro 24". Nele podemos notar uma grande participação com vários comentários de pesquisadores ${ }^{71}$ sobre o projeto. (FITA ESTEVE; CLAUDINO; SOUTO GONZÁLEZ, 2018, p. 7). Na abertura do "foro 24" lemos que

A abertura deste novo foro 24 pretende responder, desde a educação, à
dinâmica da globalização e à sociedade do conhecimento, que vem
transformar tanto os processos de aprendizagem como o interior das
instituições educativas à luz de novas formas de aprender. [...] Os problemas
locais como transporte, resíduos sólidos, poluição das águas, barulho nas
ruas, instalação de equipamentos de lazer, têm um reflexo global. Por isso,
desde o Geoforo, queremos estimular a outras pessoas que colaboram
no Projeto Nós Propomos! ou que o venham a fazer no futuro, a participar
deste Foro 24 para que possamos pensar localmente em nossos problemas e
propor ações globais que nos permitam alcançar os direitos cidadãos
universais. Este foro supõe a primeira reflexão participativa do projeto,
trazendo as experiências particulares de desenvolvimento do Projeto nos
países em que se localiza. (DOMENECH, FERNANDES, CLAUDINO,
2018).

${ }^{71}$ Até o fechamento desta investigação está registrado no foro 24 um total de 368 postagens no total. Acessado em 20 jun. 2020. 
As postagens feitas são acompanhadas com referências de artigos, comentários embasados teoricamente ou mesmo são citações de práticas pedagógicas de professores participantes, alunos de graduação ou de programas de pós-graduação. Podemos notar que ele traz contribuições para pensarmos os problemas territoriais, de exercícios de direitos políticos, da cidadania e com teorias incorporadas nos discursos e debates por meio das postagens. Isto posto, destacamos a presença de vários grupos de pesquisa participantes do GEOFORO, entre eles estão os

[...] grupos brasileños Grupo de Estudios de la Localidad - ELO, con sede en la Universidad de São Paulo (USP), en Ribeirão Preto-SP y el Centro de Estudios Agrarios e Ambientales (CPEA), con sede en la Universidade Estadual Paulista (UNESP), en Marília-SP, contribuyen directamente al Geoforo y participan del Proyecto Nos Propomos! en las respectivas ciudades. (FITA ESTEVE; CLAUDINO; SOUTO GONZÁLEZ, 2018, p. $20)^{72}$

A marcada presença dos grupos anteriormente citados reforça o compromisso deles com um processo de internacionalização da Universidade pública e com diálogos constantes e produtivos com pesquisadores da ibero-américa, por meio de uma educação geográfica voltada para a cidadania e para a análise de problemas socioambientais presentes no local. É por meio desses dois grupos que, no estado de São Paulo, o projeto Nós Propomos! foi implantado e sido desenvolvido.

Um segundo marco é o evento chamado I Congresso Ibero-Americano Nós Propomos! $!^{73}$ Geografia, Educação e Cidadania, realizado em setembro de 2018 no IGOT, na Universidade de Lisboa, Portugal, no qual estiveram presentes pesquisadores, alunos e professores participantes que implantaram e estão desenvolvendo o projeto. Na conferência de abertura do Congresso

[...] estaban presentes los representantes institucionales de las Universidades de Lisboa y Trujillo (Perú), el director del Consejo del Geoforo, además de autoridades políticas, como la Secretaria de Educación, Juventudes y Deportes de Tocantins (Brasil). Entre los asistentes (más de 150 personas) había alunos de educación básica y universitaria, asi como docentes de los diferentes niveles educativos y familiares de los alumnos más jóvenes con otras autoridades políticas

\footnotetext{
72 “[...] grupos brasileiros como o Grupo de Estudos da Localidade - ELO, com sede na Universidade de São Paulo (USP), em Ribeirão Preto/SP e o Centro de Estudos agrários e Ambientais (CPEA), com sede na Universidade Estadual Paulista, em Marília/SP, contribuem diretamente com o GEOFORO e participam do Projeto Nós Propomos! nas respectivas cidades" (tradução nossa).

73 Para mais informações do I Congresso Ibero-Americano Nós Propomos!: https://nospropomos2018.wixsite.com/home. Acesso em: 20 de out. 2019.
} 
locales. (FITA ESTEVE; CLAUDINO; SOUTO GONZÁLEZ, 2018, p. $14)^{74}$.

Notamos, portanto, a presença da comunidade escolar e do poder público local junto à universidade como forma de promover um debate produtivo e participativo nesse evento internacional. Deste congresso foi lançado um Ebook (Figura 15) com investigações sobre aportes teóricos e práticas feitas com o projeto na esfera Ibero-americana. O II Congresso Ibero-Americano Nós Propomos! estava marcado para ocorrer em julho de 2020, no colégio Pedro II, no Rio de Janeiro/RJ ${ }^{75}$.

Figura 15 - Capa da obra publicada a partir das apresentações do I Congresso Ibero-Americano Nós

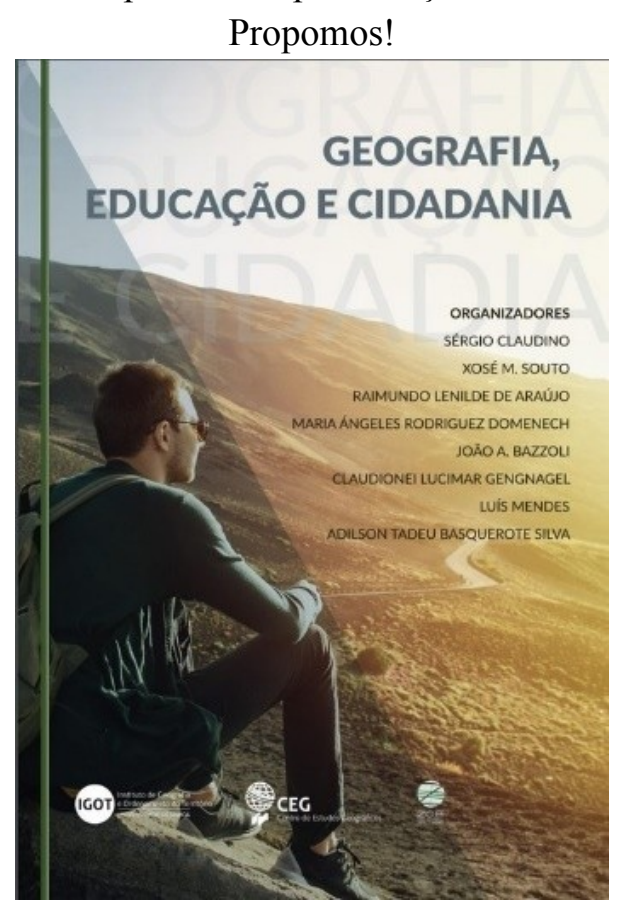

Fonte: (CLAUDINO et al., 2019)

O terceiro marco é o I Colóquio Internacional Enseñanza de la geografía y ciencias sociales: Balance de 10 años de reflexión Foro Iberoamericano Educación, Geografía y Sociedad, que ocorreu na Universidade de Los Andes, Bogotá, Colômbia, do dia 11 a 16 de março de 2019.

\footnotetext{
${ }_{74}[\ldots]$ estavam presentes os representantes institucionais da Universidade de Lisboa e Trijullo (Peru), o diretor do conselho do GEOFORO, outras autoridades políticas como a secretária de Educação, juventude e esporte do Tocantins (Brasil), entre os assistentes (mais de 150 pessoas) havia alunos de Educação Básica e Universitária, assim como professores dos diferentes níveis educativos e familiares dos alunos mais jovens com outras autoridades políticas locais" (tradução nossa).

75 Devido à pandemia do novo corona vírus o evento foi adiando para ocorrer em julho de 2021, no mesmo local e cidade que ocorreria este ano. Para mais informações ver nota de adiamento no site: https://876feb92-7cdd495a-9292-f5269ef979ae.filesusr.com/ugd/fb8dc8 7c198b1171514338a1f3276abe807ad4.pdf
} 
O evento foi organizado em parcerias com a Universidade Distrital Francisco José de Caldas, a Universidade de Los Andes e a Universidade Nacional de Bogotá e teve grande importância para o projeto, pois várias parcerias estabelecidas com universidades foram reforçadas e o projeto foi estendido para outras localidades colombianas. A estrutura do evento contemplou o âmbito organizativo, escolar, cidadão e atendeu às demandas internacionais de se pensar em conjunto, envolvendo

[...] Docentes y aprendices forman parte indisoluble de la ciudadania planetaria en sus diferentes escalas [...] y ahora también, que es posible explicar mejor la complejidad de los problemas sociales desde la geografia y la historia, y asi poder adoptar las decisiones oportunas en la vida cotidiana. (SOUTO GONZÁLEZ; ARAYA PALACIOS; RODRÍGUEZ PIZZINATO, 2019, p. 2) $)^{76}$

O Colóquio destacou a importância da educação geográfica para a construção de uma cidadania ativa nos alunos e na população em diferentes localidades da ibero-américa. Os problemas locais fazem parte do cotidiano e devem constituir objetos de estudo nas pesquisas e nas práticas da academia e da escola. Além disso, foi destacado a importância do Projeto Nós Propomos! para a validação desta cidadania ativa em âmbito ibero-americano.

A avaliação do evento e das contribuições do GEOFORO foram produtivas, pois “[...] afirmaban los ponentes, surge por la conciencia de la existencia de un espacio iberoamericano marcado por problemas sociales, que tienen que ser reflejados y debatidos a partir de la escuela y de una Geografía y de Ciencias Sociales socialmente comprometidas" (SOUTO GONZÁLEZ; ARAYA PALACIOS; RODRÍGUEZ PIZZINATO, 2019, p. 23 ) 77.

A partir das comunicações acadêmicas, do trabalho da equipe diretora e das atividades de trabalho feitas durante o evento, foi publicado a obra "La construcción global de una enseñanza de los problemas sociales desde el Geoforo Iberoamericano”, em ebook ${ }^{78}$, como forma de divulgar os trabalhos científicos apresentados e colaborar com o debate de uma educação geográfica para a cidadania. À vista disso, Carvalho Filho et al. (2019, p. 300) destacam que a participação do grupo ELO

\footnotetext{
76 “[...] docentes e alunos como parte indissociável de uma cidadania planetária em diferentes escalas [...] desta forma é possível explicar melhor a complexidade dos problemas sociais desde a Geografia e a História e assim poder contribuir com ideias oportunas para a vida cotidiana" (tradução nossa).

77 " [...] como afirmavam os trabalhos, surge a consciência da existência de um espaço ibero-americano marcado por problemas sociais, que têm que ser refletidos e debatidos a partir da escola e de uma Geografia e Ciências Sociais socialmente comprometidas" (tradução nossa).

${ }^{78}$ Para consultar a obra: http://www.ub.edu/geocrit/geoforo_iberoamericano_2019.pdf. Acesso em: 28 de fev. de 2020.
} 
[...] no I Colóquio Internacional reafirma e reforça os laços de cooperação e estratégias de cunho internacional por uma formação cidadã em esfera local e global. Por meio do GEOFORO e do projeto Nós Propomos! podemos notar a importância das ações educativas para a formação cidadã no ensino de Geografia que buscam dialogar com as urgentes demandas políticas, sociais e culturais do século XXI.

Podemos notar que estão se consolidando parcerias e materiais institucionais para compor as bases de pesquisa e de práticas do projeto na esfera Ibero-americana. Essas pesquisas começam a ser divulgadas na comunidade científica e para o público especializado na área educacional. No Brasil, em especial, temos investigações em andamento, no âmbito da pós-graduação, em quatro estados brasileiros, a saber: Universidade de Brasília (UNB/DF), Universidade Federal do Tocantins (UFT/TO), na Universidade Estadual do Centro Oeste (UNICENTRO/PR), na Universidade Estadual do Oeste do Paraná (UNIOESTE/PR) e na Universidade de São Paulo (USP/SP) ${ }^{79}$.

Estabelecemos contato com os pesquisadores por meio de eventos científicos e redes sociais para criarmos uma rede colaborativa de diálogo com relação às pesquisas sobre o Projeto. Isto posto, desenvolvemos uma síntese (quadro 4) de algumas investigações ${ }^{80}$ para facilitar o entendimento e valorizar a pesquisa brasileira. Destacamos o fato de não ter sido possível apresentar todas as pesquisas pela ausência de comunicação efetiva entre todas as instituições participantes do projeto no Brasil.

Quadro 4 - Síntese de algumas investigações sobre o Nós Propomos! defendidas e em andamento no

Brasil

\begin{tabular}{|c|c|c|c|c|c|}
\hline Pesquisador & Orientador(a) & $\begin{array}{l}\text { Instituição - } \\
\text { Estado }\end{array}$ & Investigação & Objetivo central & Defesa \\
\hline $\begin{array}{l}\text { Hugo de } \\
\text { Carvalho } \\
\text { Sobrinho }\end{array}$ & $\begin{array}{l}\text { Prof }^{\mathrm{a}} . \mathrm{Dr}^{\mathrm{a}} . \\
\text { Cristina Maria } \\
\text { Costa Leite }\end{array}$ & $\begin{array}{c}\text { Programa de } \\
\text { Pós-graduação } \\
\text { em Geografia da } \\
\text { Universidade de } \\
\text { Brasília (UNB) } \\
\text { (Tese) }\end{array}$ & $\begin{array}{l}\text { Cidadania, Lugar } \\
\text { e Educação } \\
\text { Geográfica: o } \\
\text { processo de } \\
\text { ensinar-aprender } \\
\text { Geografia por } \\
\text { meio do Projeto } \\
\text { Nós Propomos! } \\
\text { no Distrito } \\
\text { Federal. }\end{array}$ & $\begin{array}{l}\text { Analisar as práticas } \\
\text { pedagógicas em } \\
\text { Geografia na } \\
\text { construção/consolida- } \\
\text { ção da cidadania por } \\
\text { meio do Projeto Nós } \\
\text { Propomos! no Distrito } \\
\text { Federal. }\end{array}$ & $08 / 12 / 20$ \\
\hline
\end{tabular}

79 Esta investigação desenvolve-se na Faculdade de Filosofia, Ciências e Letras de Ribeirão Preto/SP, no programa de Pós-graduação em Educação.

${ }^{80}$ Não inserimos a presente investigação no quadro 4. 


\begin{tabular}{|c|c|c|c|c|c|}
\hline $\begin{array}{l}\text { Lucas } \\
\text { Halaszen }\end{array}$ & $\begin{array}{c}\text { Prof }^{\mathrm{a}} \text {. Dra } \\
\text { Marquiana de } \\
\text { Freitas Vilas } \\
\text { Boas Gomes }\end{array}$ & $\begin{array}{l}\text { Programa de } \\
\text { Pós-graduação } \\
\text { em Geografia da } \\
\text { Universidade } \\
\text { Estadual do } \\
\text { Centro Oeste } \\
\text { (UNICENTRO) } \\
\text { (Dissertação) }\end{array}$ & $\begin{array}{c}\text { Tecnologias } \\
\text { Geocolaborativa } \\
\text { s no ensino de } \\
\text { Geografia: } \\
\text { proposta didática } \\
\text { para o Ensino } \\
\text { Médio. }\end{array}$ & $\begin{array}{c}\text { Analisar as } \\
\text { potencialidades e os } \\
\text { limites das tecnologias } \\
\text { geocolaborativas no } \\
\text { desenvolvimento do } \\
\text { pensamento geográfico } \\
\text { no ensino de geografia } \\
\text { e na produção de } \\
\text { conhecimento sobre o } \\
\text { território local, com } \\
\text { vistas ao ensino de } \\
\text { geografia } \\
\text { contextualizado e } \\
\text { voltado à formação } \\
\text { para a cidadania. }\end{array}$ & $17 / 03 / 20$ \\
\hline $\begin{array}{c}\text { Lucas } \\
\text { Emmanuel } \\
\text { Teixeira }\end{array}$ & $\begin{array}{l}\text { Prof. Dr. João } \\
\text { Bazolli }\end{array}$ & $\begin{array}{c}\text { Programa de } \\
\text { Pós-graduação } \\
\text { em } \\
\text { Desenvolviment } \\
\text { o Regional da } \\
\text { Universidade } \\
\text { Federal do } \\
\text { Tocantins (UFT) } \\
\text { (Dissertação) }\end{array}$ & $\begin{array}{l}\text { A Extensão } \\
\text { Universitária } \\
\text { como estímulo à } \\
\text { Gestão Social: a } \\
\text { experiência do } \\
\text { "Nós Propomos". }\end{array}$ & $\begin{array}{l}\text { Identificar e analisar } \\
\text { quais aspectos teóricos } \\
\text { e características da } \\
\text { Gestão Social estão } \\
\text { presentes na práxis do } \\
\text { "Nós Propomos" }\end{array}$ & $03 / 03 / 20$ \\
\hline $\begin{array}{c}\text { Ana } \\
\text { Caroline } \\
\text { Tazinasso }\end{array}$ & $\begin{array}{l}\text { Prof. }^{a} \text { Dr. } \\
\text { Mafalda Nesi } \\
\text { Francischett }\end{array}$ & $\begin{array}{l}\text { Programa de } \\
\text { Pós-graduação } \\
\text { em Geografia da } \\
\text { Universidade } \\
\text { Estadual do } \\
\text { Oeste do Paraná } \\
\text { (UNIOESTE) } \\
\text { (Dissertação) }\end{array}$ & $\begin{array}{l}\text { Nós Propomos! } \\
\text { A Geografia no } \\
\text { Contexto da } \\
\text { Formação } \\
\text { Cidadã. }\end{array}$ & $\begin{array}{l}\text { Analisar o sentido e o } \\
\text { significado de estudar } \\
\text { Geografia na formação } \\
\text { cidadã do estudante do } \\
\text { Ensino Fundamental. }\end{array}$ & --------- \\
\hline $\begin{array}{c}\text { Graciele } \\
\text { Daiane } \\
\text { Gnoatto } \\
\text { Hrchorovitch }\end{array}$ & $\begin{array}{l}\text { Prof. }^{a} \text { Dr. } \\
\text { Mafalda Nesi } \\
\text { Francischett }\end{array}$ & $\begin{array}{l}\text { Programa de } \\
\text { Pós-graduação } \\
\text { em Geografia da } \\
\text { Universidade } \\
\text { Estadual do } \\
\text { Oeste do Paraná } \\
\text { (UNIOESTE) } \\
\text { (Dissertação) }\end{array}$ & $\begin{array}{l}\text { Nós Propomos! } \\
\text { perspectiva } \\
\text { metodológica } \\
\text { para o ensino de } \\
\text { Geografia nos } \\
\text { anos finais do } \\
\text { Ensino } \\
\text { Fundamental. }\end{array}$ & $\begin{array}{c}\text { Analisar as } \\
\text { possibilidades e os } \\
\text { limites do ensino e } \\
\text { aprendizagem da } \\
\text { Geografia do lugar. }\end{array}$ & $30 / 05 / 19$ \\
\hline $\begin{array}{c}\text { Eliane Maria } \\
\text { Rozin }\end{array}$ & $\begin{array}{l}\text { Prof. }^{a} \text { Dr. } \\
\text { Mafalda Nesi } \\
\text { Francischett }\end{array}$ & $\begin{array}{l}\text { Programa de } \\
\text { Pós-graduação } \\
\text { em Educação da } \\
\text { Universidade } \\
\text { Estadual do } \\
\text { Oeste do Paraná } \\
\text { (UNIOESTE) } \\
\text { (Dissertação) }\end{array}$ & $\begin{array}{l}\text { Nós Propomos! } \\
\text { Pato Branco com } \\
\text { o ensino da } \\
\text { Geografia do } \\
\text { lugar. }\end{array}$ & $\begin{array}{l}\text { Compreender como } \\
\text { ocorre a apropriação do } \\
\text { sentido no contexto } \\
\text { local, fomentando a } \\
\text { participação dos } \\
\text { estudantes na } \\
\text { identificação dos } \\
\text { problemas e na busca } \\
\text { de propostas para } \\
\text { mudanças. }\end{array}$ & $26 / 06 / 19$ \\
\hline
\end{tabular}

Fonte: elaborado pelo autor 
Notamos que as investigações (quadro 4) que estão em andamento focam, de forma direta ou indireta, na discussão de uma educação geográfica para a cidadania, tendo como meio para alcançar esse fim o desenvolvimento do Projeto Nós Propomos!. Destacamos que as três pesquisas (uma em andamento e duas realizadas) na UNIOESTE, sob a orientação da Prof. $^{\text {a }}$ Dr. ${ }^{\text {a }}$ Mafalda Nesi Francischett, e outra pesquisa realizada na UNICENTRO, sob a orientação Prof ${ }^{a}$. Dr ${ }^{\mathrm{a}}$. Marquiana de Freitas Vilas Boas Gomes, destaca o estado do Paraná envolvido com o desenvolvimento pelo ensino, pesquisa e extensão do projeto.

Temos o estado no estado do Tocantins uma pesquisa realizada sob a orientação do Prof. Dr. João Bazolli e o Distrito Federal destaca-se como sendo o único que possui pesquisa de doutorado em andamento, sob a orientação da Prof ${ }^{a}$. Dr ${ }^{\mathrm{a}}$. Cristina Maria Costa Leite. Notamos que das seis apresentadas no quadro 4, quatro já foram defendidas e publicadas e duas estão em andamento para a defesa, provavelmente em 2020.

Salientamos que das seis pesquisas apresentas, cinco delas apresentar o verbo "analisar" no objetivo central de estudo, devido à preocupação com o contexto de aprendizagem e as contribuições que o projeto promove para a educação geográfica para a cidadania. A metodologia qualitativa é empregada nas seis pesquisas para chegarem aos objetivos propostos, tendo como coleta de dados a revisão bibliográfica, elaboração de questionários, entrevistas com professores e alunos e análise de material dos estudantes como fundamentais.

Com relação aos programas destacamos que quatro dos apresentados estão em Geografia, sendo três no mestrado e um no doutorado, um está no Desenvolvimento Regional e somente um está na Educação. Desta forma, temos como indício que as pesquisas podem desenvolver-se em diferentes programas, desde que respeitados os procedimentos metodológicos da pesquisa e do ensino. Como desdobramentos dessas investigações, teremos a publicação de artigos em revistas especializadas como produtos acadêmicos voltados para a sociedade.

\subsection{O "Projeto Nós Propomos! Cidadania e inovação na educação geográfica” em São Paulo}

No Estado de São Paulo (figura 16), as ações envolvendo o referido projeto foram desenvolvidas nos municípios de Marília, por meio do Centro de Pesquisas e Estudos Agrários e Ambientais (CPEA), sob coordenação da Professora Dr. ${ }^{a}$ Silvia A. S. Fernandes, e nos municípios de Ribeirão Preto, Mococa, Ibitinga e Serrana, por meio do grupo ELO, sob a 
coordenação da Professora $\operatorname{Dr}^{\mathrm{a}}{ }^{\mathrm{a}}$ Andrea Coelho Lastória, conforme já explicitado anteriormente.

Consideremos as ações desenvolvidas com o IGOT e das duas instituições e grupos de pesquisa como sendo relevantes para o desenvolvimento das práticas pedagógicas dos professores. Desta forma, destacamos a importância da pesquisa colaborativa como “[...] atividade de co-produção de conhecimentos e de formação em que os pares colaboram entre si com o objetivo de resolver conjuntamente problemas que afligem a educação" (IBIAPINA, 2008, p. 25). Com este tipo de pesquisa, portanto, as coordenadoras do ELO e do CPEA puderam planejar, acompanhar e colaborar com o desenvolvimento e com a reflexão das práticas pedagógicas realizadas.

Houve significativo papel dos referidos grupos, assim como do GEOFORO para o contínuo diálogo e compartilhamento de experiências entre pares em prol sucesso do projeto nos municípios paulistas, focados nesta investigação.

Figura 16 - O "Projeto Nós Propomos! cidadania e inovação na educação geográfica" no estado de São Paulo

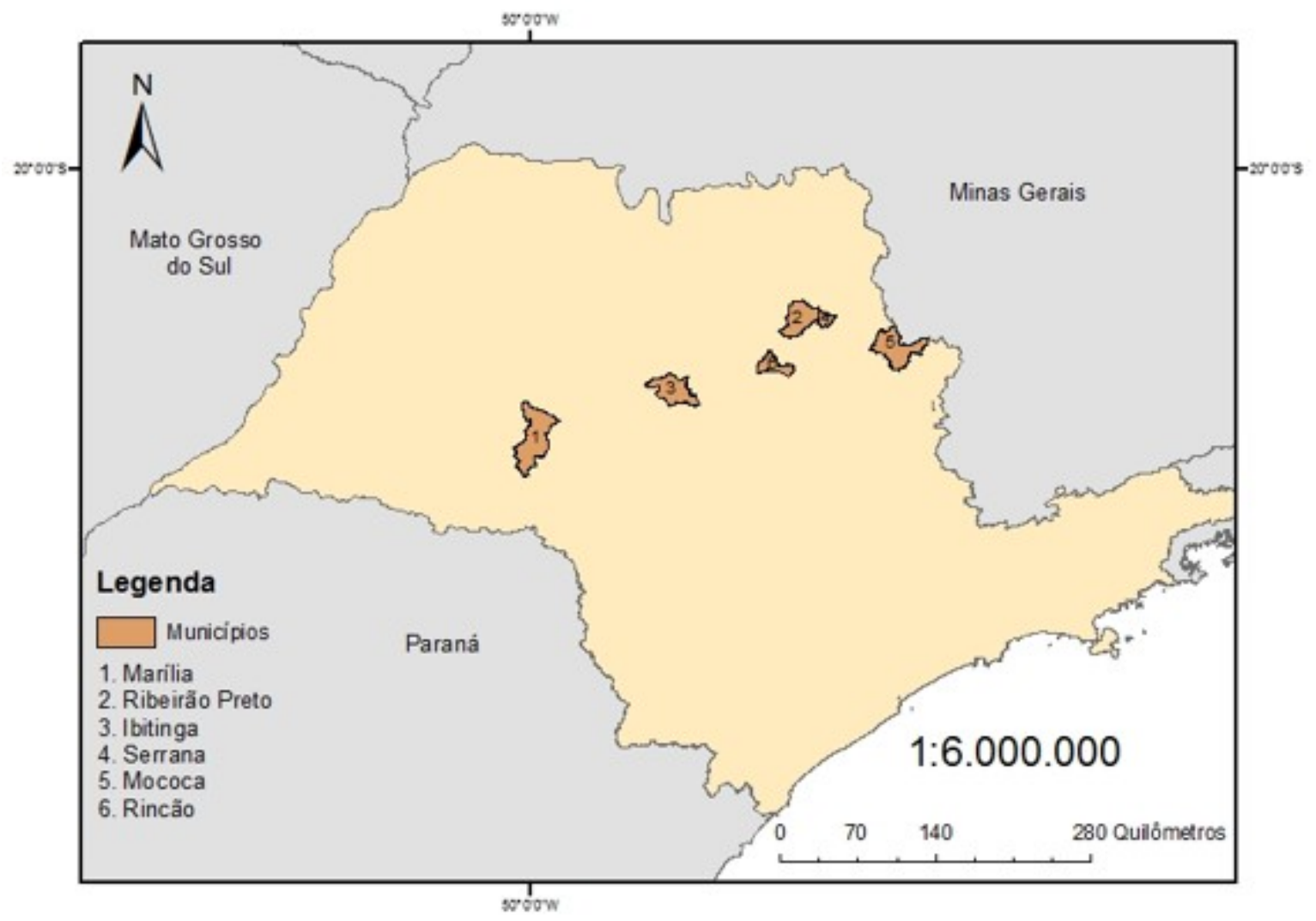

Fonte: elaborado pelo autor 
Em Marília-SP, o projeto teve início no ano de 2017, em parceria entre a Universidade Estadual Paulista (UNESP), a Faculdade de Filosofia e Ciências, de Marília-SP, o Instituto de Geografia e Ordenamento do Território (IGOT), da Universidade de Lisboa e uma escola pública da rede estadual de ensino, a Escola Estadual Oracina Correa de Moraes Rodine. O projeto reuniu as ações de dois projetos de extensão, reconhecidos e financiados pela PróReitoria de Extensão (PROEX) e pela Pró-Reitoria de Graduação (PROGRAD) da referida Universidade, e um projeto de pesquisa, com financiamento pelo CNPq.

No caso de Marília-SP, o referido projeto foi realizado em conjunto com outros dois projetos de extensão: "Currículo de Geografia e práticas ambientais: a educação geográfica e o observatório do meio ambiente", desenvolvido no âmbito dos Núcleos de ensino da UNESP, e "Meio Ambiente sob o olhar da mídia: a questão ambiental em Marília e região", por meio de bolsistas integrantes do Centro de Pesquisas e Estudos Agrários e Ambientais (CPEA), coordenado pela Professora Dr. a Silvia Aparecida de Sousa Fernandes, assessorados pelo Professor Sérgio Claudino, responsável pela criação do projeto em Portugal (LAVRATTI, 2018).

O projeto em Marília-SP iniciou-se no ano de 2017, no segundo semestre, na Escola Estadual Professora Oracina Corrêa Moraes Rodine. Foi desenvolvido pelo professor Gabriel, professor de Geografia da referida escola, nos oitavos anos (ano de 2017) e nos segundos anos do Ensino Médio, no ano de 2018. Com base nessas ações e em conjunto com alunos da licenciatura das Ciências Sociais, a discente Iara Milreu Lavratti realizou seu Trabalho de Conclusão de Curso sobre as contribuições do projeto para uma Educação Emancipatória. Neste sentido, apresenta como contribuição do projeto Nós Propomos! a preparação dos alunos da Educação Básica ( $8^{\circ}$ anos e $2^{\circ}$ anos do EM) para uma interpretação dos problemas sociais e sua formação em uma perspectiva de uma cidadania participativa para intervir no mundo social em que vivemos (LAVRATTI, 2018).

Em Ribeirão Preto-SP, a parceria foi realizada no final do ano de 2017, entre a Faculdade de Filosofia, Ciências e Letras de Ribeirão Preto (FFCLRP/USP), por meio do Grupo de Estudos da Localidade (ELO) e o Instituto de Geografia e Ordenamento do Território (IGOT), da Universidade de Lisboa, em Portugal.

Ainda no ano de 2017, o grupo ELO tomou contato com as práticas e pesquisa do "Projeto Nós Propomos! cidadania e inovação na educação geográfica" e iniciou-se um processo de levantamento de oportunidades de implantação do referido projeto por meio dos 
professores participantes. As ações educativas se iniciaram no ano de 2018 em quatro municípios: Ribeirão Preto ${ }^{81}$, Mococa, Serrana e Ibitinga.

Em ambas as universidades, o projeto desenvolveu-se de forma produtiva e colaborativa, no qual os professores participantes envolvidos puderam dialogar, constantemente, com amplo apoio dos grupos de estudos para a realização das ações educativas do "Projeto Nós Propomos! cidadania e inovação na educação geográfica". Desta forma, a colaboração dos envolvidos deu-se

[...] com o intuito de planejar, discutir e realizar práticas pedagógicas em escola pública e promover o aprendizado da educação geográfica e de temas curriculares mais amplos da educação básica, notadamente os temas vinculados às questões ambientais e aprendizagem sobre a localidade. (FERNANDES; LASTÓRIA; CLAUDINO, 2018, p. 154).

A pesquisa colaborativa à qual as autoras fazem referência diz respeito a uma pesquisa feita em conjunto entre professores participantes, alunos e componentes dos grupos de pesquisa envolvidos no projeto. Segundo Ibiapina (2008) a pesquisa colaborativa pretende agregar saberes teóricos e práticos diminuindo, assim, o denominado "abismo" entre os dois contextos.

Busca-se essa aproximação de forma que conhecimentos produzidos academicamente coadunem com as práticas docentes e a dialogicidade entre as experiências dos participantes sejam favorecidas pelos saberes científicos. Neste sentido, o diálogo permanente e a circularidade dos conhecimentos, saberes escolares e acadêmicos são pontos chaves presentes nas ações educativas.

81 O autor desta investigação realizou ações educativas do Projeto Nós Propomos! cidadania e inovação na educação geográfica em uma escola pública, no entanto não é objeto da investigação. 
Figura 17 - As parcerias do projeto Nós Propomos! realizadas no estado de São Paulo

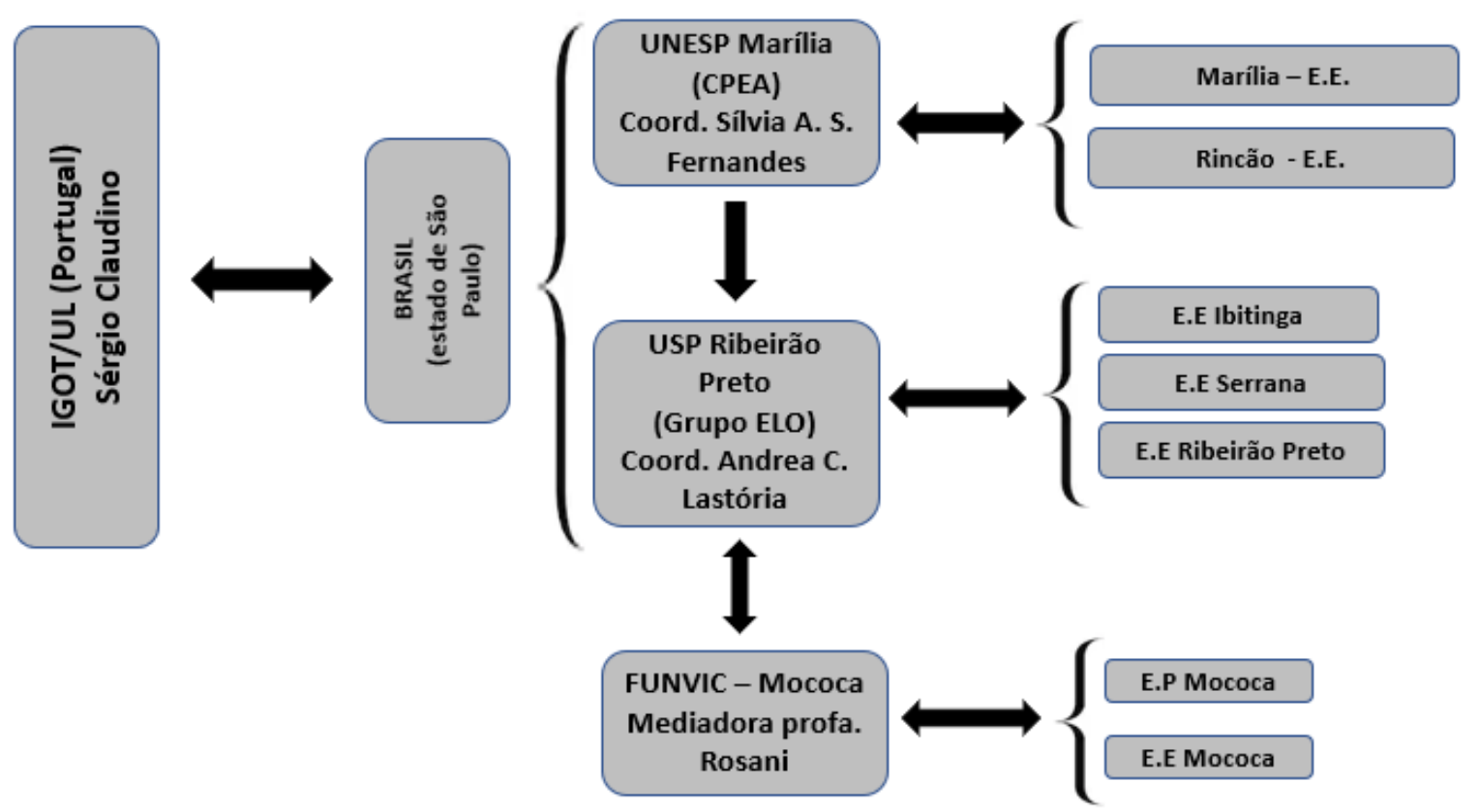

Fonte: elaboração do autor

Realizamos uma sistematização (figura 17) das parcerias realizadas entre o IGOT/UL, as instituições de ensino superior públicas USP e UNESP e as Escolas nas quais foram desenvolvidas as práticas pedagógicas pelos professores participantes do projeto Nós Propomos!.

Notamos ampla relação de trocas/compartilhamentos de conhecimentos, experiências docentes, ensino, extensão e de pesquisa (representadas pelas setas), na qual o ELO e o CPEA são mediadores das práticas ocorridas, respectivamente, em Marília-SP, Rincão-SP ${ }^{82}$, IbitingaSP, Serrana-SP e Ribeirão Preto-SP ${ }^{83}$.

A seta da UNESP está em direção à USP no sentido de explicitar que a coordenadora do CPEA é membro do ELO e assim estabelece constantes parcerias e diálogo para a reflexão das práticas pedagógicas com relação ao projeto. No caso de Mococa-SP, o ELO estabeleceu parceria com a instituição de Ensino Superior Privada Faculdade Universitária de Vida Cristã FUNVIC por meio da professora Rosani, que coordenou as práticas de dois professores de Geografia. Desta Forma, fica evidente na figura 17 a rede de parcerias pautada na forma de pesquisa colaborativa (IBIAPINA, 2008) nos municípios paulistas foco desta investigação.

\footnotetext{
82 As práticas pedagógicas realizadas em Rincão a partir de 2020 pelo professor Gabriel, sob coordenação da Dr. ${ }^{a}$ Silvia Aparecida de Sousa Fernandes, pela UNESP de Marília, não são alvo desta investigação.

${ }^{83}$ Como já destacado, o pesquisador realizou práticas pedagógicas no referido município, no entanto o mesmo e suas práticas não é o objeto de estudo desta investigação.
} 
Foi realizada em fevereiro de 2019, na Faculdade de Filosofia, Ciências e Letras de Ribeirão Preto/ USP, uma mesa redonda denominada "Participação do Grupo ELO no projeto Nós Propomos! Cidadania e inovação na educação geográfica", na qual foram apresentadas e debatidas práticas pedagógicas feitas nos municípios ${ }^{84}$ de Mococa, Ibitinga, Serrana e Ribeirão Preto. Desse evento (Figura 18) e da sistematização das práticas houve a apresentação de um trabalho escrito por cinco professores no I Colóquio Internacional Enseñanza de la geografía y ciencias sociales ${ }^{85}$, em Bogotá, na Colômbia.

Figura 18 - Apresentação das práticas pedagógicas referentes ao projeto Nós Propomos! na mesa redonda

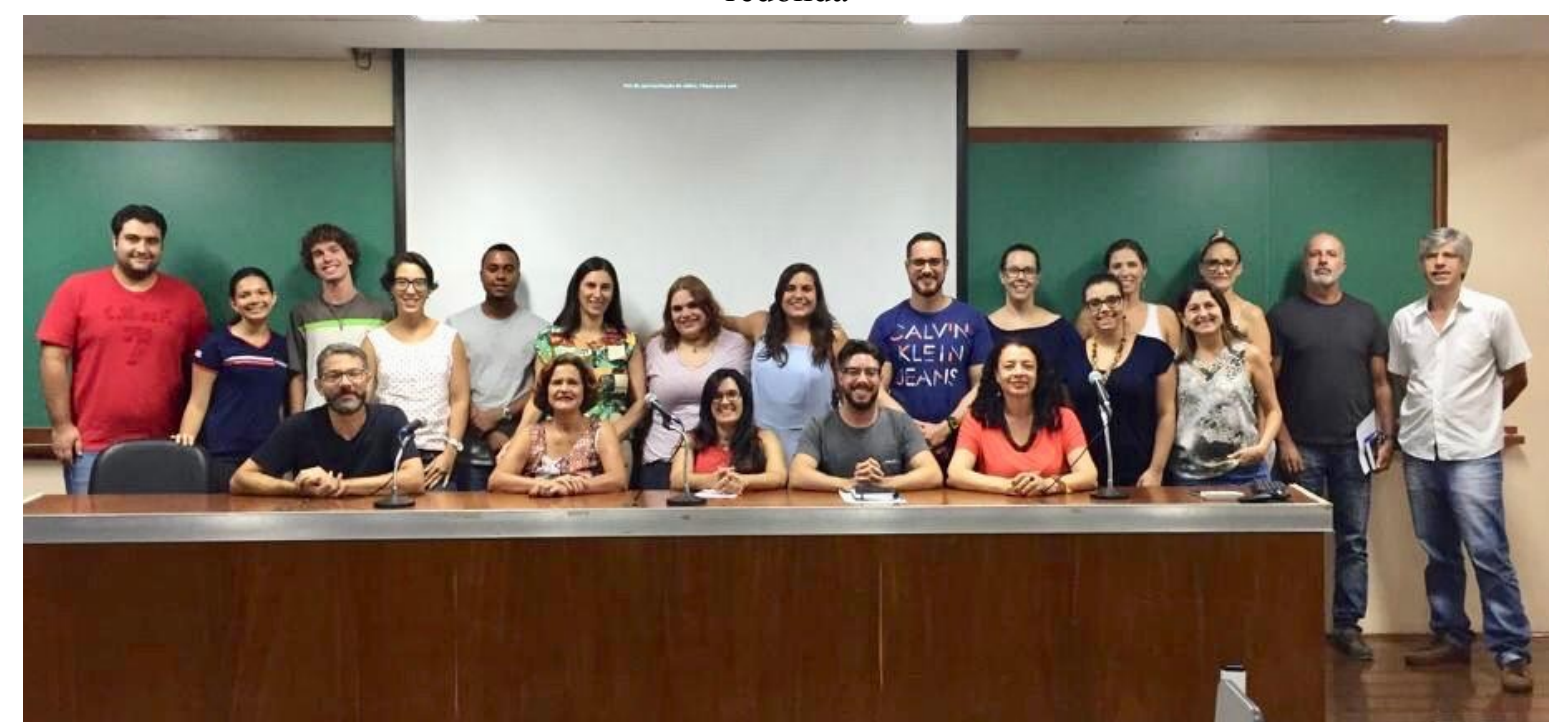

Fonte: arquivo pessoal do autor

Isto posto, alinhamo-nos à ideia de Carvalho Filho et al. (2019, p. 296) de que o grupo ELO

[...] está inserido no projeto Nós Propomos!, pois acredita na possibilidade de novas aprendizagens para superar as dificuldades atuais tendo em vista desenvolver a dimensão investigativa no campo educacional. A superação torna-se viável quando aprendemos juntos, em rede e a partir dos problemas concretos das diferentes localidades.

Até o presente momento, podemos refletir que o projeto se alinha ao combate à ideia de cidadão multifacetado (SANTOS, 2004), na medida em que instrumentaliza o aluno para entender os mecanismos legais e sociais que a democracia e as práticas da cidadania o

\footnotetext{
${ }_{84}$ A professora coordenadora do projeto na UNESP de Marília estava presente, no entanto não apresentou a prática e o professor de Geografia Gabriel não pôde comparecer ao evento.

${ }_{85}$ O referido trabalho foi publicado como capítulo de livro com o título "O Grupo de estudos da localidade, o GEOFORO e as ações vinculadas ao projeto Nós Propomos!”. Para mais informações ver: http://www.ub.edu/ geocrit/geoforo iberoamericano_2019.pdf.
} 
permitem fazer para intervir de forma ativa na sua localidade. O projeto está sendo realizado de diferentes modos e tempos no Brasil, no entanto, sem perder a ideia central que é desenvolver a cidadania territorial e o senso crítico dos alunos quanto à realidade e às contradições da globalização no espaço geográfico local.

$\mathrm{Na}$ ibero-américa e, em especial no Brasil, o projeto introduz conceitos fundamentais do meio acadêmico ao aluno como lugar, justiça social, cidadania territorial e participação social. Tudo isso em uma perspectiva de construção de um sujeito autônomo (FREIRE, 2014) que pode utilizar as suas experiências (LOURENÇO FILHO; MENDONÇA, 2014), (DEWEY, 1976) para a promoção de uma sociedade mais justa e menos desigual.

As parcerias entre universidades, escolas, comunidade local e autarquias promovem o desenvolvimento e ampliação do projeto para várias localidades do Brasil. Assim, a universidade cumpre o papel de formação de professores com o Projeto, e as escolas de Educação Básica cumprem o papel de formação cidadã de jovens estudantes, por meio da educação geográfica.

$\mathrm{Na}$ próxima seção analisamos as entrevistas feitas com professores participantes do projeto em relação às contribuições do referido projeto para eles e para os alunos. Além disso, identificamos pontos marcantes, sob suas óticas, sobre as práticas desenvolvidas nos quatro municípios paulistas. 


\title{
6 ANÁlise dOS DADOS: AS PRÁTICAS PEDAGÓGICAS DOS PROFESSORES PARTICIPANTES
}

\author{
O sucesso deste projeto une-nos no objetivo comum de \\ construirmos uma escola comprometida com as aspirações dos \\ alunos e da sociedade e, por esta forma, comprometida com a \\ formação de melhores cidadãos. (CLAUDINO, 2019a, p. 49)
}

Nesta seção, analisamos os dados coletados por meio das entrevistas com os cinco professores participantes do Projeto Nós Propomos! no estado de São Paulo, no Brasil. As entrevistas foram feitas seguindo um roteiro de perguntas (APÊNDICE A) que se alinha aos objetivos propostos de realização desta investigação, no âmbito da abordagem da pesquisa qualitativa.

Salientamos que, devido à quantidade de dados obtidos e às amplas possibilidades de análises e às várias leituras do material coletado, tornou-se indispensável definir três categorias de análise de conteúdo para haver uma interpretação coerente e produtiva nesta investigação. Criamos uma subseção para cada uma das três categorias analisadas a seguir.

a) O projeto e a formação cidadã

b) Relevância da saída de sala de aula

c) Contribuições do projeto para os professores e os alunos

As entrevistas procuraram manter o diálogo livre, crítico e cordial para captar elementos substanciais e possibilitar o desenvolvimento do nosso objetivo central. As categorias foram criadas baseadas em duas fases, sendo a primeira o isolamento e a segunda a classificação (BARDIN, 2016). Observamos repetidos conceitos e noções presentes nas entrevistas e isolamos esses elementos para podermos, em um segundo momento, realizar a “[...] classificação: repetir os elementos e, portanto, procurar ou impor certa organização às mensagens" (BARDIN, 2016, p. 148, grifo da autora).

Usamos esses procedimentos para termos um material condensado como forma de representação dos dados brutos. Desta forma, realizamos as análises por meio de fragmentos das transcrições e um aporte teórico para justificar, de modo científico, a interpretação do material coletado para chegarmos a algumas considerações neste estudo. Apresentamos, em seguida, o levantamento da caracterização dos professores participantes entrevistados para facilitar a contextualização das análises feitas nessa seção. Tal caracterização foi realizada por meio de um quadro 1 na seção 4, no entanto, a retomamos aqui para facilitar as análises. 
A primeira entrevistada é a professora Valquíria, que é graduada em Ciências Sociais na Fundação Santo André-SP (1994), com formação pedagógica em licenciatura em Geografia (1999). Possui Mestrado em Educação, pela FFCLRP, na Universidade de São Paulo (2014). Ela tem 51 anos, com 23 anos de atuação no magistério. Ministra aulas na Escola Estadual Professor Ângelo Martino, no município de Ibitinga. Desenvolveu as atividades desde a implantação do projeto (2018) até o ano de 2020. Para a investigação, consideramos as suas ações até o final do ano de 2019.

A segunda entrevistada é a professora Sonara, que é graduada em licenciatura em História pela Faculdade São Luís, em Jaboticabal-SP (2007), em licenciatura em Geografia pele Centro Universitário Barão de Mauá (2010) e em licenciatura em Pedagogia pela Universidade Metropolitana, em Santos-SP (2014). Possui especialização em Mídias na Educação pela Universidade Federal de São João Del Rei-MG (UFSJ). Mestre em Educação pela Universidade de São Paulo (2018). Possui 32 anos, com 13 anos de atuação no magistério. Ministra suas aulas na Escola Estadual Deputado José Costa no município de Serrana-SP e desenvolveu as atividades desde a implantação do projeto (2018) até o ano de 2019.

O terceiro entrevistado é o professor Gabriel, é graduado em licenciatura em Geografia pela Universidade Estadual Paulista, em Ourinhos-SP (2015) e é Mestre em Geografia pela Universidade Estadual de Londrina, no Paraná (2019). Tem 31 anos, com 6 anos de atuação no magistério. Ministrou aulas no período analisado do desenvolvimento do projeto na Escola Estadual Prof. a Oracina Corrêa Moraes Rodine, no município de Marília-SP e desenvolveu suas práticas desde a implantação (2017) até o ano de 2019.

A quarta entrevistada é a professora Rosani, é graduada em Ciências Sociais na Pontifícia Universidade Católica, em São Paulo-SP (1988). Mestre em Ciências Sociais pela Universidade de São Paulo (1997). Tem 56 anos, com 20 anos de atuação no magistério. Ministra aulas na Faculdade Universitária de Vida Cristã - FUNVIC, em Mococa-SP, no curso de Pedagogia. Atuou como mediadora do projeto em duas escolas no município de Mococa-SP, desde a implantação em 2018 até o ano de 2019.

O quinto entrevistado é o professor Américo que é graduado em licenciatura em Geografia pelo Centro Universitário da Fundação Educacional, em Guaxupé (1995). Tem 47 anos, com 27 anos de tempo de atuação no magistério. Ministra aulas na Escola Estadual Justino Gomes de Castro Maestro, onde desenvolveu práticas pedagógicas do projeto nos anos de 2018 a 2019. Em seguida, analisamos trechos das entrevistas dentro das categorias criadas em conformidade com os objetivos e a questão levantada nesta investigação. 


\subsection{O projeto e a formação cidadã}

Foi apresentado e discutido, na seção 2, a importância da educação geográfica na formação cidadã para os alunos e como a Escola pode ser o espaço privilegiado no desenvolvimento dessas práticas. Nesta subseção, analisamos as entrevistas com foco na relação entre o projeto Nós Propomos! e a formação cidadã feita aos alunos pelos professores.

Essa relação é percebida nas análises das transcrições das entrevistas. Para organizar a apresentação, padronizamos a ordem das falas dos professores da seguinte maneira: Valquíria, Sonara, Gabriel, Rosani e Américo. Discutimos como foi a implantação do projeto, sob a ótica dos professores e detalhamos as práticas desenvolvidas por eles.

Neste sentido, admitimos as práticas pedagógicas dos professores participantes analisadas nesta investigação como "[...] uma prática social orientada por objetivos, finalidades e conhecimentos, e inserida no contexto da prática social. A prática pedagógica é uma dimensão da prática social [...]" (VEIGA, 1992, p. 16). A partir desta ideia, temos como desdobramentos que as práticas envolvem a dimensão educativa e não apenas a esfera escolar e que as práticas podem promover transformações sociais nos alunos e professores.

Com relação ao conhecimento sobre o projeto, as professoras Valquíria, Sonara e Rosani afirmaram que souberam do mesmo em reuniões do Grupo ELO, em 2017. Após, realizaram a apresentação para a equipe gestora de suas escolas, para os alunos e iniciaram as práticas pedagógicas em 2018. A professora Rosani convidou dois professores ${ }^{86} \mathrm{em}^{\mathrm{m}}$ MococaSP para a realização do projeto, sendo um deles o professor Américo.

Em Marília-SP, o professor Gabriel tomou contato com o projeto e o implantou por meio de uma parceria entre a Universidade Estadual Paulista (UNESP), o Centro de Pesquisas e Estudos Agrários e Ambientais (CPEA) e sua unidade escolar, em 2017. Em todos os cinco casos, a implantação do projeto nas unidades escolares dos professores participantes contou com amplo apoio de suas equipes gestoras.

${ }^{86}$ Como apresentado na seção de metodologia, não tivemos tempos suficiente para contactar o professor que realizou as práticas na escola privada de Mococa/SP. 
Quadro 5 - Relação de quantidade de alunos e turmas

\begin{tabular}{|c|c|}
\hline $\begin{array}{l}\text { Professore } \\
\text { s }\end{array}$ & $\begin{array}{l}\text { Quantidade de alunos/turma (2017- } \\
\text { 2019) }\end{array}$ \\
\hline \multirow{2}{*}{ Valquíria } & $8^{\circ}$ anos -105 alunos \\
\hline & $8^{\circ}$ anos -140 alunos \\
\hline Sonara & $\begin{array}{l}\text { EM - } 3^{\circ} \text { ano A - } 35 \text { alunos } \\
\text { EM - } 3^{\circ} \text { ano B }-35 \text { alunos }\end{array}$ \\
\hline \multirow{2}{*}{ Gabriel $^{87}$} & $\begin{array}{l}8^{\circ} \text { ano }-20 \text { alunos } \\
8^{\circ} \text { ano }-25 \text { alunos }\end{array}$ \\
\hline & EM $2^{\circ}$ anos -120 alunos \\
\hline Rosani $^{88}$ & $\begin{array}{l}8^{\circ} \text { ano I - } 30 \text { alunos } \\
8^{\circ} \text { ano II }-30 \text { alunos }\end{array}$ \\
\hline Américo & $8^{\circ}$ ano $\mathrm{C}-25$ alunos \\
\hline & Total: 575 alunos \\
\hline
\end{tabular}

Fonte: elaborado pelo autor

O quadro 5 exibe a quantidade de alunos/turmas com os quais os professores participantes do projeto realizaram suas práticas pedagógicas. A respeito da professora Rosani, os números dizem respeito aos alunos da escola privada em que ela coordenou as práticas em conjunto com outro professor, não entrevistado para esta investigação. Notamos que o número total foi de, aproximadamente, $\mathbf{5 7 5}$ alunos. Um número expressivo para as realidades locais dos municípios e as condições de trabalho docente da realidade brasileira.

Isto posto, apresentamos as falas dos professores quanto à relação do projeto com a formação cidadã aos seus alunos. A professora Valquíria afirma que o projeto pôde demonstrar que

[...] mesmo em um período de conjuntura nacional em que é desqualificado a questão da política e dos políticos, eu acho que eles puderam ter um olhar diferente para a questão política. E olhar para a cidade também é um ato político, uma ação política, identificar os seus problemas e se colocar frente a eles a modo a intervir. (Valquíria)

\footnotetext{
${ }^{87}$ Valor apresentado em trabalho acadêmico. Para mais informações: https://www.eselx.ipl.pt/sites/default/files/ media/2019/e-book simposio compressed.pdf. Acesso em: 01 de mar. 2020.

${ }_{88}$ Consideramos a escola privada FUNVIC nas análises, coordenada pela professora Rosani.
} 
Neste sentido, sob a ótica da professora Valquíria, o projeto relaciona-se com o ato de participação social na localidade em que o aluno estabelece suas relações com a comunidade e desenvolve sua identidade e seu pertencimento à escola e à comunidade. A professora Valquíria complementa a afirmação anterior dizendo que achou

[...] o projeto muito importante no sentido de promover a cidadania nos alunos, a participação e para mim, é a participação cidadã-política dos alunos [...] eles são ativos, que podem ter o seu protagonismo, que nós [professores] iremos desenvolver em sala de aula e isso vai se estender para a vida deles fora da escola, como cidadãos, como membros de uma sociedade. (Valquíria)

O relato da professora alinha-se à educação geográfica na formação cidadã, pois estabelece "[...] identificación, comprensión y explicación del entorno en el que se desenvuelve el futuro ciudadano y los desafios que, inevitablemente, deberá enfrentar" (ARAYA PALACIOS; ÁLVAREZ BARAHONA, 2019, p. 5$)^{89}$.

Além disso, a fala da professora relaciona-se à cidadania como forma de participação social nos espaços públicos e a tomada de decisão dos alunos como forma de melhorar seus próprios espaços de vida. Segundo Cavalcanti (2012, p. 46), a “[...] participação política e coletiva das pessoas nos destinos da sociedade". Para os alunos poderem participar de forma ativa na política, realizou-se em Ibitinga-SP, um estudo dos problemas locais. Dessa forma, a professora Valquíria enfatiza

[...] a identificação dos problemas, quando eles [os alunos] param para olhar para a cidade e observa os problemas ou as necessidades que ali se apresentam também [...] porque às vezes não é um problema, às vezes é uma coisa que falta, então eu acho que esse momento é muito importante. Está aí, estamos construindo cidadãos atuantes. (Valquíria)

[...] processo, a leitura da localidade, da paisagem, mesmo isso sendo essencial para a gente, foi muito importante para os alunos poderem propor, porque eu sempre destaquei isso, o projeto chama-se "Nós Propomos!", propõe para quem? Propõe para o poder público, então foi muito importante para eles poderem propor para o poder público. (Valquíria)

89 “[...] identificação, compreensão e explicação do ambiente em que o futuro cidadão opera e dos desafios que ele inevitavelmente terá de enfrentar" (tradução nossa). 
A ideia posta pela professora Valquíria de cidadãos atuantes é reiterada pelo projeto Nós Propomos! constantemente e a questão destacada "Propõe para quem?" explicita a cobrança ao poder público local. Além disso, segundo Claudino e Santiago Rivera (2019, p. 288), vai ao encontro de uma formação cidadã que orienta o modelo de Educação

[...] para fomentar la formación del ciudadano como actor fundamental de la dinámica política, con propuestas curriculares promovidas para optimizar la toma decisiones comunitarias sobre las necesidades ambientales, geográficas y sociales con opciones pedagógicas que fomenten el protagonismo social $l^{90}$.

Seguindo essa ideia de Santiago Rivera e Claudino (2019), a professora Sonara, ao realizar suas práticas em Serrana-SP, notou que os alunos realizaram vários questionamentos e tiveram a oportunidade de fala, durante a realização do projeto e, em espacial, no trabalho de campo.

[...] alunos começaram a apontar vários questionamentos, tudo envolvendo os problemas que eles tinham levantado, eles [os alunos] não ficaram somente na questão do calçamento, eles destacaram principalmente o calçamento e, na oportunidade, eles falaram de todos os problemas que eles tinham encontrado. $\mathrm{O}$ vice-prefeito ouviu, falou bastante e colocou o seu secretário da infraestrutura para falar. (Sonara)

Diante disso, notamos que a localidade é valorizada nas práticas pedagógicas do projeto, por meio das vivências e questionamentos dos próprios alunos, em um processo de levantamento crítico dos problemas que afetam a população. A professora Sonara também explicita a escuta do poder público executivo local. Em conformidade com o relato das professoras, admitimos que a educação geográfica para a cidadania também pode apresentar “[...] una gran potencialidad para desarrollar el sentido de pertenencia en los alumnos y para relacionar los espacios vividos y percibidos con el desarrollo de habilidades intelectuales superiores como el análisis y la sínteses" (ARAYA PALACIOS; ÁLVAREZ BARAHONA, 2019, p. 5) ${ }^{91 .}$.

\footnotetext{
90 “[...] promover a formação do cidadão como ator fundamental na dinâmica política, com propostas curriculares promovidas para otimizar a tomada de decisões da comunidade sobre necessidades ambientais, geográficas e sociais, com opções pedagógicas que promovam a liderança social" (tradução nossa).

91 “" [... grande potencial para desenvolver um senso de pertencimento nos alunos e relacionar espaços vividos e percebidos com o desenvolvimento de habilidades intelectuais mais elevadas, como análise e síntese (tradução nossa).
} 
Essa pertença e identidade poderá desenvolver-se com a participação dos alunos nas demandas e decisões do poder público. A professora Sonara destaca, ainda, dois apontamentos percebidos com sua prática:

[...] os alunos terem percebido como participantes do projeto e da aprendizagem, pela ação, porque a ação foi principalmente no bairro deles [...] O projeto começou com um café com política para tentar integrar essas duas turmas e com o projeto Nós Propomos! a intenção foi promover ainda mais a integração [...] como ocasionalmente os meninos do $3^{\circ} \mathrm{A}$ eles moram a maior parte no Jardim D. Pedro e o $3^{\circ} \mathrm{B}$ a maior parte moram no Jardim das Rosas, acabou que cada sala decidiu percorrer um caminho, para não causar mais conflito, para que não querer impor a vontade na sala sobre a outra, decidimos que seriam dois caminhos percorridos, sendo cada um por sala. (Sonara)

No relato anterior, notamos que a cidadania pode ser construída com a participação social do coletivo nos assuntos da comunidade e que a prática teve a função de promover o diálogo entre as duas turmas que estavam em conflito. A prática promoveu maior proximidade entre as turmas ao estudarem os problemas locais em comum, de elaborarem propostas de intervenção pontuais na Escola e, em seguida, para o poder público. Isto posto, consideramos a afirmação de Matos $(2005$, p. 37) de que um dos designíos da Educação para a cidadania é " [...] contribuir para a construção de um mundo mais igualitário e com maior justiça social”.

Quanto às práticas pedagógicas em Marília-SP, o professor Gabriel não apresentou, de forma explícita, em sua entrevista, uma relação entre o projeto e a formação cidadã, no entanto, destaca que o projeto promoveu nos alunos e possibilitou o "olhar" para diferentes espaços de vida. Aspecto fundamental para se promover a formação cidadã.

[...] a valorização do outro, por mais que você vai ver a realidade local ali, passou por diversos bairros ali, o aluno entendendo um pouco da vida do outro pode fazer uma reflexão sobre a sua própria vida também. (Gabriel)

A promoção da percepção e valorização do coletivo fica evidente para o professor Gabriel. Essa percepção amplia-se na medida em que os alunos vão reconhecendo seu bairro e os aspectos da sua realidade local. Neste sentido, o relato sobre a prática desenvolvida em Marília alinha-se com dois fundamentos da educação geográfica para a formação cidadã, pois pôde proporcionar uma "[...] una actitud cívica responsable. Así, por ejemplo, la empatía con 
los otros seres humanos y el compromiso por solucionar los problemas sociales son fundamentos de una convivencia pacífica, tolerante y solidaria" (ARAYA PALACIOS; ÁLVAREZ BARAHONA, 2019, p. 4) $)^{92}$.

Isto posto, a formação do aluno está relacionada entre o que se aprende na Escola e as práticas pedagógicas desenvolvidas pelo Projeto. Quanto às práticas ocorridas em Marília-SP, Lavratti (2018, p. 50) complementa que o projeto

[...] preparou para que pudéssemos avançar na prática de educação ambiental, nos conscientizando do papel da disciplina de Geografia e da educação voltada para a conscientização e a emancipação dos sujeitos. Ao se pensar nessas questões, surgem reflexões acerca do exercício da cidadania, já que os sujeitos, ao adquirirem conhecimentos técnicos e científicos, tendem a transformar sua realidade e obter maior qualidade de vida, ao reconhecer e exigir seus direitos e, exercendo, assim, sua efetiva cidadania.

Alinhando-se ao pensamento da autora, a fala do professor Gabriel salienta que o projeto mostra uma nova concepção de ensino de Geografia, mais compreensível aos alunos, na medida em que os torna aptos a intervir na sua dada realidade.

[...] pra eles [os alunos] porque que a gente vai sair, o que significa para eles, dar mais sentido de por que ver Geografia em sala de aula [...] eu consegui ver muitos alunos colocarem em prática, vamos dizer assim, uma nova concepção de ensino de Geografia, eu vi a transformação de muitos alunos [...] é uma das coisas que o projeto tem no seu campo de visão [...] você tornar o aluno apto a intervir na situação. (Gabriel)

Destacamos o fato de o professor Gabriel ter desenvolvido o projeto com diferentes turmas de alunos, sendo, no ano de 2017, com duas turmas ( $8^{\circ}$ ano A e B), no ano de 2018, com duas turmas do $2^{\circ}$ ano do Ensino Médio. Como citado anteriormente, o professor Gabriel mudou-se para o município de Araraquara-SP, em 2019 e, desta forma, atualmente, trabalha com o projeto em uma unidade escolar do município de Rincão/SP, por meio da coordenação do Centro de Pesquisas e Estudos Agrários e Ambientais (CPEA). Lavratti (2019, p. 89) destaca que em Marília-SP o projeto

[...] por sua dimensão e importância foi desenvolvido pela bolsista do projeto, integrantes do Centro de Pesquisas e Estudos Agrários e Ambientais (CPEA) e voluntários, totalizando seis graduandas de Ciências Sociais, além

92 “[...] uma atitude cívica responsável. Assim, por exemplo, a empatia com outros seres humanos e o compromisso com a solução de problemas sociais são os fundamentos de uma convivência pacífica, tolerante e solidária" (tradução nossa). 
do professor da rede Estadual de Ensino Básico e da coordenadora do projeto, assessorados pelo Professor Sérgio Claudino, responsável pela criação do projeto em Portugal.

Notamos o grande auxílio e parceria estabelecida entre o CPEA, a UNESP, o IGOT e graduandos do curso de Ciências Sociais. Desta forma, o projeto pôde ser desenvolvido de forma produtiva, com discussões e planejamentos para promover uma formação cidadã aos alunos da escola pública e, possibilitar ainda, uma formação inicial mais sólida para os participantes do curso de Ciências Sociais. Assim, a extensão cumpriu seu papel social de aproximar a Universidade da população e da comunidade. Isto posto, o professor explicita como foi a implantação do projeto na escola em que trabalhou:

Depois do contato inicial com a professora Sílvia, eu fui conversar com o pessoal da minha escola que seria responsável [pelo projeto] com a coordenação, vice direção e a direção. A escola entendeu e achou importante a saída dos alunos, e ao mesmo tempo o contato com o Ensino Superior, com o contato direto com os estudantes e professores do Ensino Superior [...] eles [equipe gestora] acharam que isso "oxigena" um pouco o espaço escolar, é um pensamento que eu compartilho. (Gabriel)

Notamos que o professor e a equipe gestora acolheram, com entusiasmo, a ideia do projeto por compartilharem uma mesma concepção de Educação para a formação cidadã. A intervenção no local dos alunos, em seu espaço vivido, permitiu uma ação ativa dos alunos, tanto da Escola quanto da Universidade.

Salientamos, então, que as práticas pedagógicas desenvolvidas em Marília-SP puderam despertar o olhar dos alunos para o local, promovendo uma ressignificação como sujeitos sociais e cidadãos ativos na sociedade. Lavratti $(2019$, p. 91) complementa que a realização do projeto, em Marília-SP, com a Escola Pública vai

[...] ao encontro de uma Educação mais crítica, transformadora e emancipatória. Pudemos perceber que as práticas desenvolvidas permitiram reflexões cada vez mais profundas sobre a realidade local e nacional em nossos estudantes, podendo ser decisivas no processo de desenvolvimento destes sujeitos. 
Quanto às práticas em Mococa/SP, a professora Rosani coordenou dois professores ${ }^{93}$ por meio de uma parceria entre a Faculdade FUNVIC, no curso de Pedagogia ${ }^{94}$, o Grupo ELO e as escolas de ensino básico (figura 17).

A professora Rosani admite o projeto Nós Propomos! como sendo uma metodologia ativa na Educação para a cidadania. Neste sentido, recorremos a ideia de Gemignani (2012, p. 10 apud RIGAMONTE, 2019, p. 2863) para se referir às metodologias ativas como a possibilidade desses

[...] novos instrumentos técnico-pedagógicos tornam possível a participação ativa do aluno em seu processo de aprendizagem, buscando conhecimento, articulando teoria-prática, correlacionando os seus conhecimentos e realizando reflexões críticas sobre problemas reais que envolvem sua formação profissional, integrados às exigências do mundo do trabalho e contribuindo para o desenvolvimento da sociedade, da tecnologia e da ciência.

As metodologias ativas são usadas para práticas inovadoras que deslocam a ideia de um aluno passivo do saber para um aluno ativo do saber, no sentido de promover reflexões críticas e ações locais para discussão dos problemas reais da comunidade. Queiroz (2019, p. 42) diz que as práticas “[...] devem ser pautadas através de metodologias ativas que propiciem atividades de ensino que estimulem a auto-reflexão por parte dos estudantes”. Neste sentido, Rosani afirma que

[...] esse termo que nós usamos hoje de tornar nosso aluno como protagonista, de interagir com a realidade, de tornar cidadão [...] ele tem direitos e deveres, de interagir, de fazer diferença, de entender qual é a estrutura do meio que ele [o aluno] está, principalmente como funciona todas as estruturas políticas e de como é o poder público. (Rosani)

Rosani alinha-se à ideia de a cidade poder ser um espaço de aprendizado para todos, em especial para se tornar cidadão de fato, por ações mediadas pelo professor. Assim, Cely Rodríguez e Moreno Lache (2015, p. 116) afirmam que “[...] se tiene que aprender sobre su oferta social y ambiental; así mismo hay que conocer las instituciones que la gobiernan y

\footnotetext{
93 Como destacado anteriormente, não conseguimos realizar a entrevista com o professor da escola privada mediada pela professora Rosani. Para fins de análises recorremos ao relato da referida professora para elaborarmos um leve panorama da situação da escola privada.

${ }^{94}$ O Projeto Nós Propomos! está registrado como um projeto de extensão vinculado ao curso de Pedagogia.
} 
administran. Todo ello se debe aprender y, por supuesto, enseñar en las instituciones escolares $[\ldots]^{\prime, 95}$.

A professora Rosani, como mediadora de dois professores em Mococa, afirma que o projeto cumpriu sua função de promover a leitura da realidade e das relações sociais existentes, nas distintas unidades escolares onde foi desenvolvido. Ela aponta que o desafio de ser mediadora do projeto foi o fato de não estar sempre presente na sala ${ }^{96} \mathrm{e}$, assim, não conhecer, de fato, dada realidade dos alunos. Ela afirmou também que

[...] quando é o professor da disciplina eu acho que facilita, porque ele conduz melhor o conteúdo e interage mais adequadamente com a turma [...], mas de toda a maneira, era uma realidade que eu tinha que enfrentar e foi assim que aconteceu [...]. (Rosani)

Isto posto, o projeto fez o aluno interagir com o seu espaço vivido para poder intervir de forma produtiva, no sentido de refletir sobre uma qualidade de vida digna para a população local. Destacamos que a visão da professora Rosani é de mediadora então seu lugar de fala é o da Educação Superior. Rosani, explicita como iniciou a implantação do projeto

[...] eu trabalhei com duas escolas, uma pública e uma privada. A escola FUNVIC que é privada, e a escola Maestro Justino que é uma escola pública estadual. A professora de Geografia da escola privada é também diretora na escola pública, então facilitou, por isso que eu a escolhi [a escola]. Ela é professora de Geografia [...] eu pensei nessa possibilidade, como eu trabalho com a formação de professores na Pedagogia, eu pensei em usar a escola que faz parte da faculdade, da instituição que eu trabalho [FUNVIC] para colocar em prática o "Nós propomos!" [...] eu escolhi exatamente por isso. Eu pensei em um caminho, já que eu não sou a professora, como eu vou trabalhar com isso? (Rosani)

O caminho descrito pela professora reforça a importância que o Ensino Superior tem na Educação Básica, em promover a formação continuada com os professores, por meio de projeto de ensino e de parcerias institucionais.

\footnotetext{
95 “[...] precisa-se aprender sobre sua oferta social e ambiental; tem-se que saber sobre as instituições que a governam e administram. Tudo isso deve ser aprendido e, é claro, ensinado em instituições escolares [...]" (tradução nossa).

96 Em alguns momentos a professora Rosani atuou diretamente com alunos e professores para acompanhar e orientar o desenvolvimento das ações do projeto.
} 
[...] então, eu acabei fazendo o papel de "ponte", das escolas [pública e privada] com as ONGs, poder público, marcando as visitas, conhecendo a estrutura primeiro para depois levar os alunos [...] então eu fiz o trabalho de auxiliar o professor nessa construção, nesse diálogo fora da sala de aula, então foi o meu papel de protagonizar [...] e de colocar o professor nesse caminho, auxiliando o seu trabalho. (Rosani)

[...] então eu trabalhei com os [dois] professores interagindo. Eu ajudava o professor e ajudava as turmas e fazia o trabalho fora da sala de aula [...] então os contatos, a interação e isso me inspirou, e foi nesse caminho que acabei tentando organizar o "Nós propomos!" no município de Mococa-SP. (Rosani)

Ela destaca que trabalhou dentro de suas possibilidades e condições e que encontrou um "caminho" para o projeto, como mediadora. Neste trabalho de mediação, em Mococa-SP, é descrito pela professora Rosani como sendo uma "ponte" entre a escola e demais instituições sociais como a própria universidade, organizações não governamentais e o poder público, cumpre o papel da extensão universitária. Neste sentido, Bazolli et al. (2017, p. 97, grifo nosso) nos lembra que

[...] a clara percepção do distanciamento das universidades brasileiras, nas salas de aula, laboratórios e gabinetes, da realidade social do país. Portanto, é possível afirmar que a extensão universitária se constitui em atividade de conexão comunitária à medida que o ensino e a pesquisa não estão respondendo aos interesses de tal realidade. Nesse sentido, a extensão assume definitivamente um papel transformador, sobretudo, da dura realidade de parcelas ainda majoritárias da população que não têm acesso aos direitos fundamentais, pelo menos, garantindo às pessoas esses benefícios essenciais.

Desta forma, as práticas pedagógicas desenvolvidas em Mococa-SP e nos outros municípios paulistas, abrangem ações de grande importância para a sociedade, na medida em que aproximam a Universidade com comunidade, para promoção de uma transformação social.

Destacamos, ainda, a importância da extensão como forma de parceria entre a Universidade e a Escola, no qual ambas ganham, pois “[...] em razão de propiciar um trabalho qualitativo de extensão universitária ampliada à comunidade local" (BAZOLLI; COSTA E SILVA; VIANA, 2017, p. 12). A escolha de ser mediadora em duas diferentes redes de ensino 
permitiu que Rosani comparasse o desenvolvimento do projeto em duas realidades distintas, por meio de muito aprendizado no processo com o projeto.

[...] a ideia de trabalhar com a pública e a privada no mesmo ano $\left[8^{\circ}\right]$ para perceber e comparar mesmo, como essas diferentes realidades interagem em um processo de cidadania [...] é importante olhar para espaços escolares e redes de ensino distintos. Nós [Rosani e os dois professores] passamos por muito aprendizado nas duas unidades escolares. (Rosani)

Segundo Rosani, na escola pública, o projeto apresentou mais dificuldades do que na escola privada, devido ao fato de os alunos não estarem acostumados a participarem de projetos temáticos diversos e estarem em uma condição de vulnerabilidade social, o que aumento os desafios do professor e da mediadora. Apesar das diferentes das dificuldades, o professor Américo percebeu que a

[...] formação para cidadania foi fantástica, o respeito ao próximo, aos gêneros e às culturas de cada um. Então dessa forma a formação para cidadania aconteceu, os nossos alunos passaram a valorizar coisas, como empatia, gentileza, prontidão, que eles não valorizavam, inclusive o seu próprio corpo e sua condição de saúde [...] dessa forma eles se tornaram pessoas melhores, mais solidárias e promotoras de ações cidadãs. (Américo)

O professor Américo considerou que o projeto alcançou bons resultados, com o destaque para a valorização do próprio corpo como relacionado à promoção de uma qualidade de vida para a cidadania e de valores humanos, como empatia, gentileza prontidão, não pensados antes pelos alunos. A preocupação dos alunos foi com a saúde pública do adolescente e os modos e meio do cuidado com o corpo. Neste sentido, Rigamonte (2019, p. 2870) traz que

Os temas que preocupam os alunos da escola pública e privada são bem diferenciados. A saúde pública é uma necessidade e uma deficiência na vida dos alunos da escola pública, já os da escola privada centram o seu interesse em questões ambientais, visando o bem-estar coletivo, mas preocupados com interesses relacionados a sua realidade, as deficiências das estruturas do estado como educação, saúde e moradia, afetam menos sua reflexão.

Os alunos de ambas as unidades escolares, em Mococa-SP, puderam perceber os problemas locais, seus impactos na vida cotidiana, meios de intervenção em suas dadas 
realidades e as falhas do poder público em proporcionar uma estrutura eficiente de saúde e infraestrutura para a população. Desta forma, Claudino $(2019 b, 361)$ nos lembra que "Pupils have the freedom to choose what projects they think interests them. They therefore tend to vary a little according to the characteristics of the areas in which they live" ${ }^{\prime 97}$.

Após projetos desenvolvidos os alunos propuseram os temas presentes nas investigações locais, portanto, eles foram considerados como agentes ativos pelos professores. Como forma de sintetizar as práticas pedagógicas desenvolvidas nos municípios paulistas, elaboramos o quadro 6 que apresenta o professor, os temas trabalhados, os principais problemas, as propostas apresentadas, a Escola e o município no qual foram desenvolvidos. Neste sentido, podemos notar que as cinco práticas alinham-se a mais dois princípios do projeto (CLAUDINHO, 2019a, 2019b).

5. Construtivismo - Aposta-se na definição dos temas/problemas dos projetos pelos próprios alunos, de forma que os mesmos lhes sejam significativos - sem prejuízo do diálogo que há sempre com o professor.

6. Diálogo/horizontalidade - As universidades assumem, habitualmente, a coordenação do Projeto, havendo situações de escolas que avançam individualmente. Em qualquer caso, deve existir um diálogo estreito entre as universidades e as escolas de ensino não superior sobre o desenvolvimento do Projeto. Contudo, como se referirá adiante, o crescimento do Projeto tem estado associado a uma diminuição do diálogo entre a universidade e as escolas (CLAUDINO, 2019b, p. 39, grifo nosso)

Quadro 6 - Sistematização das práticas pedagógicas desenvolvidas pelos professores participantes

\begin{tabular}{|c|c|c|c|c|c|}
\hline Professor (a) & Temas & Turmas & $\begin{array}{c}\text { Principais } \\
\text { problemas } \\
\text { encontrados }\end{array}$ & $\begin{array}{c}\text { Propostas } \\
\text { apresentadas }\end{array}$ & $\begin{array}{c}\text { Escola / } \\
\text { Município }\end{array}$ \\
\hline \multirow[t]{2}{*}{ Valquíria } & $\begin{array}{c}\text { Direito a } \\
\text { serviço } \\
\text { público de } \\
\text { qualidade }\end{array}$ & $\begin{array}{c}3 \text { turmas } \\
\text { de } 8^{\circ} \\
\text { anos } \\
(2018)\end{array}$ & $\begin{array}{l}\text { - Praças públicas } \\
\text { em condições } \\
\text { precárias; } \\
\text { - Ausência de } \\
\text { lixeiras; } \\
\text { Depredação } \\
\text { patrimonial e } \\
\text { mato alto. }\end{array}$ & $\begin{array}{l}\text { Revitalização e } \\
\text { arborização das } \\
\text { praças públicas } \\
\text { por parte do } \\
\text { poder local; } \\
\text { Campanhas de } \\
\text { conscientização } \\
\text { dos moradores } \\
\text { para ocupação e } \\
\text { preservação do } \\
\text { espaço. }\end{array}$ & $\begin{array}{c}\text { E.E. } \\
\text { Professor } \\
\text { Ângelo } \\
\text { Martino } \\
\text { Ibitinga/SP }\end{array}$ \\
\hline & $\begin{array}{c}\text { Direito ao } \\
\text { serviço } \\
\text { público de } \\
\text { qualidade }\end{array}$ & $\begin{array}{c}4 \text { turmas } \\
\text { de } 8^{\circ} \\
\text { anos } \\
(2019)\end{array}$ & $\begin{array}{l}\text { - Falta de } \\
\text { manutenção nas } \\
\text { praças da } \\
\text { cidade } \\
\text { (capinação, } \\
\text { poda, }\end{array}$ & $\begin{array}{l}\text { Manutenção e } \\
\text { embelezamento } \\
\text { regular da } \\
\text { praça; } \\
\text { - } \\
\text { Colocação de } \\
\text { equipamentos: }\end{array}$ & \\
\hline
\end{tabular}

97 "Os alunos têm a liberdade de escolher quais projetos eles pensam que lhes interessam. Eles, portanto, tendem a variar um pouco de acordo com as características das áreas em que vivem” (tradução nossa). 


\begin{tabular}{|c|c|c|c|c|c|}
\hline & & & $\begin{array}{l}\text { recolhimento de } \\
\text { lixo, etc.); } \\
\text { Falta de bancos, } \\
\text { parque infantil, } \\
\text { bebedouros, } \\
\text { etc.; } \\
\text { - Falta de } \\
\text { iluminação. }\end{array}$ & $\begin{array}{l}\text { bebedouros, } \\
\text { academia ao ar } \\
\text { livre, } \\
\text { parquinhos etc.; } \\
\text { Ampliação do } \\
\text { Programa } \\
\text { "adote uma } \\
\text { praça" para } \\
\text { maior adesão de } \\
\text { empresários. }\end{array}$ & \\
\hline Sonara & $\begin{array}{c}\text { Mobilidade } \\
\text { urbana }\end{array}$ & $\begin{array}{c}2 \text { turmas } \\
\text { de } 3^{\circ} \text { anos } \\
\text { E.M }\end{array}$ & $\begin{array}{l}\text { - Asfalto } \\
\text { danificado, falta } \\
\text { de calçamento; } \\
\text { - Ausência de } \\
\text { iluminação } \\
\text { pública. }\end{array}$ & $\begin{array}{l}\text { Elaboração de } \\
\text { pedido de } \\
\text { intervenção do } \\
\text { poder público local } \\
\text { para reforma do } \\
\text { asfalto. }\end{array}$ & $\begin{array}{l}\text { E. E. } \\
\text { Deputado } \\
\text { José Costa } \\
\text { Serrana/ } \\
\text { SP }\end{array}$ \\
\hline \multirow[b]{2}{*}{ Gabriel $^{98}$} & $\begin{array}{l}\text { Meio } \\
\text { ambiente } \\
\text { Urbano } \\
(2017)\end{array}$ & $\begin{array}{l}2 \text { turmas } \\
\text { de } 8^{\circ} \text { anos }\end{array}$ & $\begin{array}{l}\text { - Moradias em } \\
\text { áreas de risco; } \\
\text { - } \text { Pavimentação } \\
\text { urbana; } \\
\text { - } \quad \text { Resíduos } \\
\text { sólidos; } \\
\text { Efluentes } \\
\text { industriais. }\end{array}$ & $\begin{array}{l}\text { - Ação do poder } \\
\text { público para } \\
\text { elaboração de } \\
\text { leis municipais } \\
\text { mais rigorosas; } \\
\text { - } \\
\text { Fiscalização e } \\
\text { denúncias por } \\
\text { parte da } \\
\text { população. }\end{array}$ & \multirow{2}{*}{$\begin{array}{c}\text { E. E Prof. } \\
\text { Oracina } \\
\text { Corrêa } \\
\text { Moraes } \\
\text { Rodine } \\
\text { Marília/SP }\end{array}$} \\
\hline & $\begin{array}{l}\text { Relação } \\
\text { campo- } \\
\text { cidade } \\
(2018)\end{array}$ & $\begin{array}{c}3 \text { turmas } \\
\text { de } 2^{\circ} \text { ano } \\
\text { E.M. }\end{array}$ & 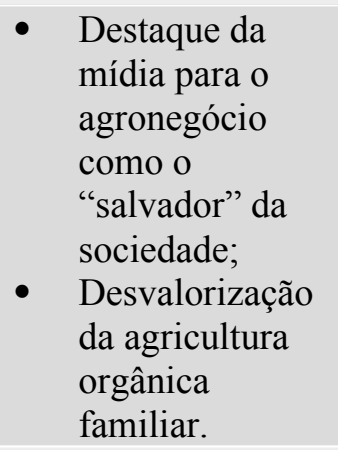 & $\begin{array}{l}\text { - Valorização da } \\
\text { agricultura } \\
\text { orgânica } \\
\text { familiar; } \\
\text { Conscientização } \\
\text { das pessoas } \\
\text { quanto à } \\
\text { segurança } \\
\text { alimentar. }\end{array}$ & \\
\hline \multirow[t]{2}{*}{ Rosani ${ }^{99}$} & $\begin{array}{c}\text { Arborização } \\
\text { urbana }\end{array}$ & $\begin{array}{l}1 \text { turma } \\
\text { de } 8^{\circ} \text { ano }\end{array}$ & $\begin{array}{l}\text { Falta de uma } \\
\text { ciclovia na } \\
\text { cidade e falta } \\
\text { de arborização. } \\
\text { falta de coleta } \\
\text { seletiva, } \\
\text { problemas com } \\
\text { mata ciliar em } \\
\text { áreas urbanas. }\end{array}$ & 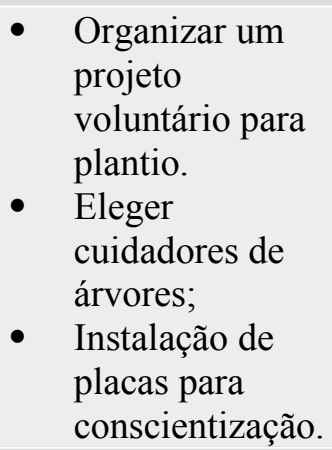 & \multirow[t]{2}{*}{$\begin{array}{c}\text { FUNVIC } \\
\text { Mococa/SP }\end{array}$} \\
\hline & $\begin{array}{c}\text { Revitalizaçã } \\
\text { o de espaço } \\
\text { público }\end{array}$ & $\begin{array}{l}1 \text { turma } \\
\text { de } 8^{\circ} \text { ano }\end{array}$ & $\begin{array}{l}\text { Queimadas; } \\
\text { desperdício de } \\
\text { água; lixo; } \\
\text { arborização; }\end{array}$ & $\begin{array}{l}\text { Ampliar a } \\
\text { arborização do } \\
\text { espaço e o } \\
\text { número de }\end{array}$ & \\
\hline
\end{tabular}

98 Destacamos no quadro algumas propostas elencadas pelos alunos. Foram muitas apresentações em formato de banners feitas na Escola Estadual.

99 Apresentamos os dados da prática desenvolvida na escola privada em Mococa/SP coordenada pela professora Rosani. 


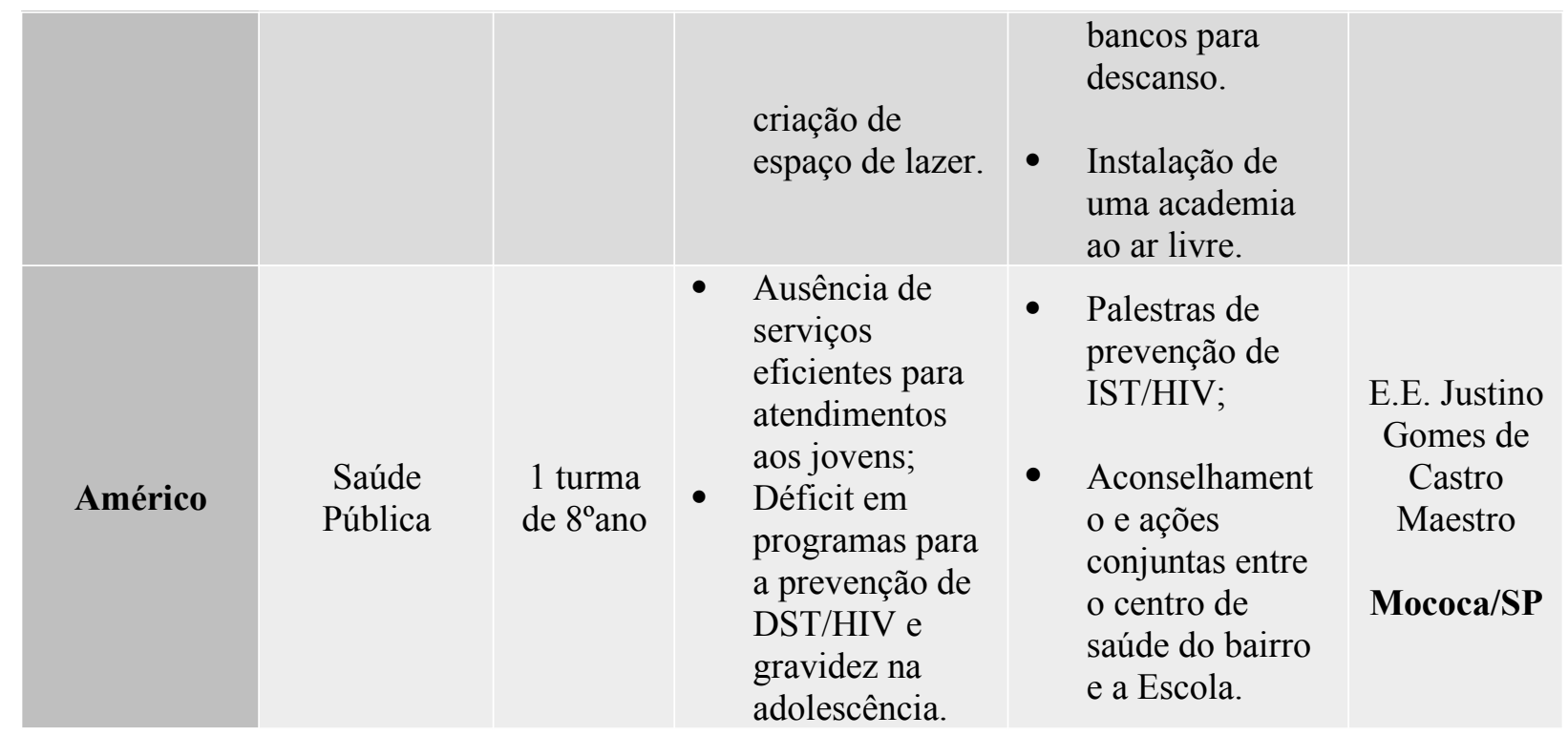

Fonte: elaborado pelo autor

Foram estabelecidas parcerias produtivas entre as universidades e as escolas participantes e os intercâmbios de experiências e informações entre ambas as instituições ocorreram plenamente. Durante o processo, houve diálogo entre professores e os alunos. Os diálogos seguiram os princípios de horizontalidade.

O quadro 6 apresenta as turmas que realizaram o projeto Nós Propomos!. Nele percebemos uma maior incidência de turmas do Ensino Fundamental ( $8^{\circ}$ anos) e menor incidência de turmas do Ensino Médio ( $2^{\circ}$ e $3^{\circ}$ anos). O Projeto é voltado, inicialmente, para o ensino secundário (Ensino Médio), no entanto, na ibero-américa e no Brasil, vem tomando novas configurações. Assim, abrange, também, os anos finais do Ensino Fundamental, em especial $8^{\circ}$ e $9^{\circ}$ anos, além de cursos superiores, cursos técnicos e técnicos integrados ao médio, entre outros (CLAUDINO, 2019a, 2019b). Para exemplificar a diversidade de práticas e de pesquisa no Brasil, destacamos o trabalho de Tazinasso e Francischett (2019) como parte de um estudo, na Pós-graduação, que investiga a implantação e o desenvolvimento do Projeto em uma turma de alunos do $7^{\circ}$ ano de uma Escola Estadual no município de Verê, no Paraná.

Além disso, destacamos que o quadro 6 apresenta uma diversidade de temáticas. Os temas têm ligação com os grandes problemas socioambientais locais. Esses temas foram previamente alinhados com os conteúdos de Geografia durante seu levantamento em todas as turmas das unidades escolares. Em consonância com nossa análise, Cavalcanti (2019, p. 209, grifo nosso) destaca que ao trabalhar conteúdos da Geografia, estes podem ter ampla relação com a vida cotidiana como 
[...] deslocamento, mobilidade, transporte, moradia, acesso a espaços públicos, oferta de serviços variados. Esta abordagem liga a Geografia a questão de cidadania. Abordar esses temas, com o objetivo de desenvolver capacidades de análise mais crítica [...] pode ser um caminho profícuo para se qualificarem ações cidadãs no enfrentamento da injustiça social.

Isto posto, cabe ressaltar que as práticas pedagógicas analisadas estão ligadas a uma educação geográfica que "[...] interessa conhecer o mundo interligando os problemas do lugar com as demandas globais" (CALLAI, 2010, p. 22). Os problemas socioambientais detectados, analisados e com propostas de solução virão a atender e garantir a qualidade de vida das populações.

Cada realidade, a seu tempo e especificidade, foi flexibilizada para poder implantar e desenvolver o projeto Nós Propomos! nos municípios estudados. Tal feito vai ao encontro de um dos princípios do projeto, que é a "3 Flexibility: Each school, each university, each mode of education has its own specific contexts. Respect for this diversity is consolidated as the We Propose! Project spreads to other countries and other levels of education" (CLAUDINO, 2019 b, p. 356, grifo do autor) ${ }^{100}$.

Pautar o debate nas escolas com questões ligadas ao direito à serviços públicos de qualidade (Ibitinga), mobilidade urbana (Serrana), meio ambiente urbano e relação campocidade (Marília), saúde pública, arborização urbana e revitalização de área em frente à escola (Mococa) é indicativo da relevância que o local assume nas práticas desenvolvidas.

Neste sentido, os alunos elencaram problemas urbanos que afetam, diretamente, a vida da população, pois sinalizaram uma preocupação com o espaço de vivência e como este espaço implica em suas vidas. Em Mococa-SP, a turma da escola estadual caminhou para o desenvolvimento de propostas para o tratamento do problema elencado pelos alunos. $\mathrm{O}$ professor Américo, no entanto, explicita o desafio que foi trabalhar o projeto e as propostas com a turma.

[...] é uma escola onde nós temos uma carência socioeconômica e familiar muito grande de nossos alunos [...] nós vamos encontrar muitas mães que abandonam os filhos, muitos pais que estão presos, vamos encontrar alunos que dependem da casa abrigo, alunos que temos que acionar o conselho tutelar por algum motivo. (Américo)

100 Flexibilidade: cada escola, cada universidade, cada modo de educação tem seus próprios contextos específicos. O respeito por essa diversidade é consolidado à medida que o Projeto Nós Propomos! se espalha para outros países e outros níveis de Educação (tradução nossa). 
Em consonância com Américo, a professora Rosani destaca o fato de a turma apresentar muitas defasagens de aprendizagem, estarem em uma condição de vulnerabilidade social e não ter mais tempo no planejamento para desenvolver o restante das ações do projeto

[...] a turma apresenta desafios com muitas defasagens, houve pouco interesse da turma em estabelecer propostas e precisávamos de mais tempo para amadurecer as ideias com a turma. (Rosani)

Mesmo com esse cenário desafiador, foi possível elaborar propostas sobre os problemas locais e apresentá-las, em sala, visando à melhoria das condições de saúde dos estudantes e, assim, proporcionar impacto direto no seu bem-estar e em seus pensamentos e comportamentos.

Diante do que foi apresentado, elaboramos o quadro 7 para sintetizar os elementos de cidadania presentes, de forma explícita e implícita, nas falas dos professores.

Quadro 7 - Síntese de elementos da cidadania na visão dos professores participantes

\begin{tabular}{|c|c|}
\hline $\begin{array}{c}\text { Professor } \\
\text { participante }\end{array}$ & Concepção de cidadania \\
\hline Valquíria & $\begin{array}{l}\text { Participação social } \\
\text { Apropriação do local vivido } \\
\text { Protagonismo juvenil }\end{array}$ \\
\hline Sonara & $\begin{array}{c}\text { Participação social } \\
\text { Apropriação do local vivido } \\
\text { Escola como espaço da } \\
\text { cidadania }\end{array}$ \\
\hline Gabriel & $\begin{array}{l}\text { Participação social } \\
\text { Apropriação do local vivido } \\
\text { Protagonismo juvenil }\end{array}$ \\
\hline Rosani & $\begin{array}{l}\text { Sujeitos ativos do conhecimento } \\
\text { Autonomia } \\
\text { Escola como espaço da } \\
\text { cidadania }\end{array}$ \\
\hline Américo & $\begin{array}{c}\text { Debates críticos } \\
\text { Sujeitos ativos do conhecimento } \\
\text { Autonomia }\end{array}$ \\
\hline
\end{tabular}

Fonte: elaborado pelo autor

Sob a ótica dos participantes, as práticas pedagógicas (VEIGA, 1992) colaboraram para a promoção promoveram uma formação cidadã. Esta formação fica evidenciada pela 
concepção de cidadania assumida pelos professores e sintetizada no quadro 7. A participação social, discutida anteriormente, como um elemento importante para a constituição da cidadania é destacada no trabalho de Teixeira (2020), que admite o projeto como promotor da participação social e da interação social em Tocantins.

Os elementos trazidos no quadro 7 alinham-se, também, ao estudo de Lastória et al. (2015b) sobre a cidadania e a Educação para a cidadania, no contexto brasileiro. Neste trabalho, fica evidente que professores entrevistados compactuam com a ideia de cidadania como o "lugar que ocupa [m]" as pessoas no mundo para a participação efetiva nos espaços públicos e relacionada às esferas jurídicas e sociais da vida humana.

As práticas permitiram despertar nos alunos, sob a ótica dos professores, uma ressignificação do ensino de Geografia, por meio das ações de investigação e intervenção na comunidade. Esta análise vai ao encontro de uma educação geográfica como sendo "Community-based learning, undertaken through the problem-solving of concrete issues, in constant dialogue with the community in question" (CLAUDINO, 2019b, p. 382) ${ }^{101}$. Em consonância com essa ideia, a professora Sonara afirma que a comunidade foi acionada durante o desenvolvimento do projeto. O professor Gabriel destaca a proposição dos alunos, baseadas no diagnóstico dos alunos feitas da realidade, como uma das ações fundamentais no projeto.

[...] os alunos, já levantamos as perguntas para a entrevista estruturada que os alunos fariam na sua comunidade [...] na semana seguinte os alunos trouxeram essa entrevista já respondida pelos pais, os vizinhos e o pessoal da comunidade [...] percebi um apoio da comunidade com relação às ações desenvolvidas com o projeto. (Sonara)

Os alunos falaram para ele [o vice-prefeito] "você se prepara para ouvir, que você vai ouvir bastante" ele [o vice-prefeito] riu e falou "nós estamos aqui para isso mesmo né, para que a comunidade possa agir mesmo sobre os problemas". (Sonara)

[...] seria a proposição deles para as problematizações que aconteceram em campo. Quando o aluno volta do campo ele volta diferente, você percebe a diferença na leitura da dada realidade [...] as propostas de muito valor, pois são baseadas nas dificuldades diagnosticas pelos alunos. (Gabriel)

101 "Aprendizagem comunitária, realizada através da solução de problemas e questões concretas, em constante diálogo com a comunidade em questão” (tradução nossa). 
Fica evidente pelas falas dos professores que o projeto avançou na promoção de uma formação cidadã. Isto posto, no estado de São Paulo, cada professor, dentro de suas limitações e realidades locais, percebeu que o projeto promoveu significantes reflexões e ações em prol da formação cidadã.

A participação dos alunos está presente na fala dos professores. Segundo os professores participantes, os alunos participaram em maior ou menor número, de acordo com a escola com apontamentos importantes para a construção das propostas de intervenção dos problemas investigados. A fala da professora Valquíria relaciona a participação dos alunos ao desenvolvimento da autonomia deles, como agentes ativos de possíveis mudanças sociais. $\mathrm{O}$ professor Gabriel destaca que o projeto desenvolveu a participação dos alunos para entender e interpretar a dada realidade, de forma mais profunda e responsável como forma de ressignificação da realidade desse aluno.

[...] a participação dos alunos no Projeto Nós Propomos! possibilitou o conhecimento da localidade em que vivem, das características geográficas, bem como os problemas que são ali encontrados. $\mathrm{Na}$ busca dessas resoluções, os alunos puderam desenvolver sua autonomia em relação ao processo de desenvolvimento de cada fase do projeto. (Valquíria)

[...] o projeto treinou os alunos para a tomada de decisões e na elaboração de propostas [...] eles entenderem que a realidade não é exatamente como pensamos [...] as vezes devemos repensa-la, as vezes intervir na realidade ou mesmo repensar e vive-la, de forma responsável, [...] não é possível tomar decisões sem participação nas várias esferas da sociedade, de alguma forma [...] a participação pode promover a ressignificação, desse aluno, frente a dada realidade. (Gabriel)

Neste sentido, podemos nos apoiar no estudo de Teixeira (2020) sobre práticas do projeto Nós Propomos! em Tocantins (TO), no qual percebeu ampla participação dos envolvidos no processo, incluindo alunos, pessoas da comunidade, gestores e professores.

Aspecto relevante a ser ressaltado é o fato do projeto ser implantado, em sua maior parte, em escolas públicas da rede estadual (quadro 2), e ser discutido entre os alunos e os professores de forma harmônica e dialógica (FREIRE, 2004) na busca pelo conhecimento no espaço escolar. Cabe aqui lembrar que, segundo Teixeira (2020, p. 121),

[...] é complexo a implementação de propostas com a abordagem do Nós Propomos dentro de um sistema fechado que são as escolas estaduais, que possuem práticas e procedimentos pré-determinados pelos currículos 
escolares, os quais não dão espaço para flexibilização do/no processo de aprendizagem dos estudantes, agentes fundamentais para que o projeto de fato aconteça.

Assim como ocorreu em Tocantins, os casos estudados no estado de São Paulo indicam que os professores conseguiram superar seus currículos fechados pelos sistemas implantados nas redes de ensino e usaram suas experiências, diálogo e maturidade intelectual para adaptar-se e, assim, promover práticas pedagógicas diferenciadas e voltadas a uma educação geográfica mais participativa.

O projeto Nós Propomos! tem como um dos seus fundamentos a possibilidade de desenvolvimento da Multidisciplinaridade (CLAUDINO, 2019a, 2019b), entendida aqui como a possibilidade dois ou mais professores realizarem diálogos e parcerias de práticas pedagógicas entre seus pares. Isto posto, percebemos a valorização do amplo saber e dos conhecimentos escolares distribuídos por disciplinas escolares, sendo a Geografia a promotora da ação. Neste sentido, Claudino (2019a, p. 40) destaca que "[...] o Projeto surge em Geografia, mas enriquece-se com a colaboração com outras áreas disciplinares”. Pudemos notar nas falas de duas participantes a presença desse aspecto

O projeto foi multidisciplinar com o professor de Artes que desenvolveu o concurso do logotipo do
projeto, ele se envolveu e foi muito interessante o envolvimento dele. A professora de Português
acompanhou na interpretação dos vídeos que eram assistidos, ela também discutiu com os alunos o
que era um seminário, porque os alunos do ensino Fundamental II de 13,14 anos não têm muita
prática em apresentar um seminário, pelo menos na escola onde eu trabalho [...] ela [professora de
Português] trabalhou a questão do seminário com eles, trabalhou a questão da apresentação dos
seminários. (Valquíria)
[...] a professora de Artes foi muito companheira porque ela cedeu mais aulas e nós acabamos
resolvendo o projeto juntas [...] ela pediu que a avaliação da aula de Artes fosse o desenvolvimento
de um vídeo sobre os problemas da localidade. (Sonara)

Fica explícito, pelas falas, o estabelecimento de parcerias para a realização do projeto nas unidades escolares. As ações multidisciplinares, no sentido de promoção de uma integração de disciplinas escolares, ocorreram. 
No caso do professor Gabriel, houve a participação de seis graduandos de Ciências Sociais da UNESP de Marília, em conjunto com a Prof. ${ }^{a}$ Dra. Sílvia Aparecida de Sousa Fernandes no desenvolvimento das práticas.

A professora Rosani admitiu que não houve parcerias multidisciplinares entre os professores das unidades escolares mediadas por ela. O professor Américo confirma a fala de Rosani, ao admitir que não houve parcerias dele com outros professores da sua unidade escolar. A professora Rosani destaca que os professores foram convidados, porém não quiseram aderir a proposta por diferentes motivos.

[...] até tentamos fazer uma reunião com o grupo dos professores apresentando o que o projeto tem de propostas, mas a demanda de trabalho e as condições lá [escola pública] são bem complicadas. Os professores se interessaram e gostaram do projeto, mas ninguém quis abraçar ou participar, de fato, em relação ao projeto. A questão da multidisciplinaridade ficou no campo da Geografia mesmo com o professor Américo, que tinha um bom relacionamento com a turma. (Rosani)

Por meio dessas ações, pudemos notar que, no estado de São Paulo, o projeto não conseguiu avançar como vocação multidisciplinar (CLAUDINO, 2019a, 2019b). Desta forma, podemos apontar que um dos desafios para o futuro do projeto Nós Propomos! será ampliar as ações coordenadas e a lógica de cooperação entre os professores de uma mesma unidade escolar para a promoção efetiva e ampla de práticas multidisciplinares.

Isto posto, um segundo desafio é como lidar com o alto grau de vulnerabilidade social, no qual se encontra uma parcela significativa dos alunos. Será que essa vulnerabilidade pode comprometer o desenvolvimento ou mesmo a finalização do projeto com determinadas turmas? No caso de Mococa, a vulnerabilidade foi um desafio presente na turma do professor Américo e mediada pela professora Rosani.

Apontamos, portanto, que os professores participantes encontraram limitações de ordens e graus distintos em cada realidade escolar e de turmas. No entanto, confrontaram-nas e desenvolveram o projeto Nós Propomos! de forma flexível e em consonância com a tarefa da disciplina de Geografia "[...] de contribuir com a formação humana cidadã, ativa, crítica e propositiva" (CAVALCANTI, 2019, p. 44).

\subsection{Relevância da saída da sala de aula}


Foi apresentado, na seção 3, a importância das saídas da sala de aula para a promoção de uma educação geográfica voltada para a cidadania. Foram elencadas duas ações centrais que devem permear a saída da sala de aula que são o trabalho de campo e o estudo do meio, além disso, a relação de ambos com o projeto Nós Propomos!.

Nesta seção, analisamos, sob a ótica dos professores, a relevância das saídas da sala de aula para o desenvolvimento do referido projeto, assim como seus avanços e desafios para a promoção do projeto, no estado de São Paulo. Admitimos que o ambiente escolar, segundo Lastória et al. (2015b, p. 196) é o

[...]il luogo adatto per l'esercizio dela cittadinanza vissuta. Lascuola dovrebbe essere accessibile a tutti i soggetti, con garanzie indistinte per tutti, come guida all' apprendimento, nel fare i compiti, all' acesso di material e contenuti, nel rapoorto com gli studenti $e$ anche con gli insegnanti e el grupodirettivo ${ }^{102}$.

Assim, propomos averiguar, sob a ótica dos participantes, a relevância das saídas da sala de aula para ampliar esse potencial de promoção da cidadania, que a escola já apresenta. De acordo com professora Valquíria, a saída da sala de aula é um facilitador para o desenvolvimento de práticas cidadãs, na medida em que desperta nos alunos a consciência da complexidade de dada realidade e possibilidade da intervenção nessa realidade.

[...] são muito importantes, pois elas buscam trazer para o concreto aquilo que a gente trabalha nos livros, no material didático. É um momento de grande interação entre alunos e professores, ele enriquece muito o aprendizado, tornando esse aprendizado mais significativo [...]. (Valquíria)

[...] a gente acaba instruindo o aluno de forma cidadã mesmo, ele precisa entender o contexto em que ele está inserido, ele precisa entender de escola pública [...] ele precisa entender de educação de jovens e adultos, a questão da inclusão, eu acho que o exercício é esse. (Valquíria)

A professora enfatiza a importância do aluno entender o contexto e a escola que ele vive, para um aprendizado significativo e o exercício da cidadania. Nesse sentido, notamos uma consonância da fala da professora com uma prática pedagógica e um ensino de Geografia que “[...] trata em seus conteúdos questões do mundo e da realidade atual e pode oferecer, a

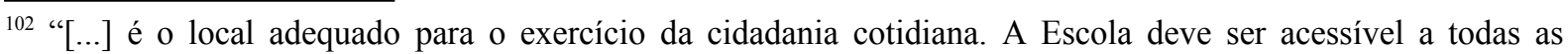
disciplinas com garantias indistintas em tudo, como um guia para aprender, fazer a lição de casa, acessar conteúdos, no relacionamento com alunos e também com os professores e gestores" (tradução nossa). 
partir dos seus conceitos, ferramentas intelectuais para que o aluno possa entender o mundo a partir do lugar em que vive" (DEON, CALLAI, 2018, p. 287).

A professora Sonara destaca que os alunos podem explorar melhor a localidade em que vivem por meio das saídas da escola e que além disso, é possível desenvolver noções espaciais significativas.

[...] a localidade, o caminho que eles elegeram como norte, se eles escolheram aquele lugar para seguir oriento eles a explorarem o lugar com o olhar deles [...] somente o ato de sair de dentro da escola já fazem eles [os alunos] vivenciar outras experiências e outras noções espaciais [...]. (Sonara)

Acredito que é muito importante para que o aluno tenha uma experiência espacial que vai além do quadrado da sala de aula, assim ele amplia o campo de visão que ele tem de todos os dias [...] então é viver a Geografia isso, sair da sala de aula é viver a Geografia no cotidiano e na prática. (Sonara)

O professor Gabriel ressalta vários benefícios da saída da escola para implementar o processo de ensino e, também, a aprendizagem dos alunos.

Quando a gente sai da sala de aula é como aquilo que foi conversado dentro da sala de aula, que está ligado com o mundo fora da escola. Então, eu acho que essas saídas, quando a gente consegue ir à campo, a gente consegue fortalecer o processo da formação do pensamento deles [os alunos] e, sem dúvida, é uma formação de pensamento, mesmo que seja incipiente, de um pensamento geográfico, como a ideia de pensar o mundo a partir do espaço [...] de onde as coisas estão, porque elas estão ali, como elas funcionam [...]. (Gabriel)

Para você conseguir entender fenômenos e processos que acontecem em locais distantes, tem que ter mesmo padrão [...] é preciso ver que isso tem ao seu redor. Se você conseguir olhar para esse espaço ao seu redor, enxergar coisas que estão, a princípio, invisíveis, como intencionalidade, funcionalidade do espaço. (Gabriel)

Os trechos de falas do professor indicam a valorização que ele atribui às saídas da sala de aula. É possível notar uma ampla relação entre o que é ensinado na teoria e o que é visto e vivido na prática. Também é nítido a promoção do pensamento crítico de dada realidade e, ainda, é colocado que os fenômenos podem ser de ordem global e local e que a saída à campo, possibilita a compreensão dos alunos. A fala do professor Gabriel está alinhada com a ideia de 
Oliveira e Assis (2009) sobre o fato do trabalho de campo completar as lacunas existentes entre os conteúdos escolares, os livros didáticos e o conhecimento do professor.

Além disso, desenvolver a percepção das funcionalidades do espaço pelos alunos, por meio dos estudos prévios em sala deve ser pensando e praticado pelo professor e "[...] propicia avaliar a participação do aluno na leitura da realidade desenvolvendo o senso crítico, atitudes de responsabilidade e consciência do mundo em que vivem" (OLIVEIRA; ASSIS, 2009, p. 199).

Em consonância com a fala do professor Gabriel, para a professora Rosani, as saídas da escola são fundamentais para incentivar o protagonismo, conhecer melhor sua realidade e possibilitar ao professor e ao aluno a relação teoria e prática.

[...] ação fundamental, incentiva esse protagonismo, sair da sala de aula, conhecer a realidade na prática para depois poder teorizar sobre aquilo, e também, fazer as proposições, conhecer toda essa estrutura de funcionamento das instituições da sociedade que são importantes para a aprendizagem dos alunos. (Rosani)

A professora Rosani destaca que o sair da sala, o professor pode "despertar" o protagonismo nos alunos, na medida em que eles vão conhecer e ler dada realidade. Alinhada com a fala de Rosani, Cavalcanti (2019, p. 120) destaca a importância da observação e do olhar dos alunos "[...] como uma capacidade de se questionar a realidade, entendendo que os fenômenos não estão localizados por acaso [...] há uma lógica que justifica essa localização".

O professor Américo também destaca a relação entre teoria e prática:

[...] a saída de sala de aula para a formação dos alunos é muito boa porque nós [professores] colocamos em prática muito aquilo que está sendo discutido no currículo, em teoria. Dessa forma, eu consigo trazer para os alunos uma maior proximidade com a realidade que cada um vive. (Américo)

Quanto à realização das saídas da sala de aula, os professores nos relatam formas variadas e modos distintos de realizá-las. A forma predominante foi por meio do trabalho de campo. As práticas pedagógicas desenvolvidas pelos professores não se encerraram com o trabalho de campo. Desta forma, as referidas práticas se alinham aos princípios do projeto Nós Propomos! e à ideia de estudo do meio (LOPES; PONTUSCHKA, 2010). 
De modo geral, os cinco professores participantes reconhecem desafios em realizar a saída da sala de aula, em especial para fora do espaço escolar. Apresentaram, como desafios, questões ligadas à burocracia para a saída dos alunos, a questão da dificuldade de deslocamento até o local a ser estudado entre outros. As falas da professora Valquíria e Rosani exemplificam o exposto.

O que impede é a questão da logística para tirar aluno da sala de aula. É muito trabalhoso no sentido de que você precisa ter transporte e, às vezes, você não consegue o transporte fornecido gratuitamente, temos [os professores] que pagar. Depois, você tem que organizar as autorizações, pagamentos [...] são desafios a serem superados. (Valquíria)

[...] não posso esquecer de ressaltar que as saídas da sala podem ser dificultadas, pois na escola pública não há recursos necessários disponíveis para proporcionar estas saídas de forma coletiva e constante. (Rosani)

Diante desse cenário problemático Rosani e Américo, relataram desafios que enfrentaram para a realização do projeto com os alunos da escola púbica.

[...] tivemos dificuldades [...] então para fazer duas visitas, nós fomos com o meu [carro] e o carro do professor, então nós escolhemos alguns alunos para ir em uma entrevista. Depois o outro, tem que levar outra parte do grupo, para fazer as oficinas [...]. A gente teve que fazer todo um movimento para conseguir um ônibus. (Rosani)

A dificuldade da escola púbica não aconteceu na escola privada. Rosani explicita, que nesta última, todos os alunos das duas turmas do $8^{\circ}$ ano participaram das práticas fora da escola. Nesta houve pagamento do transporte, pelos alunos, para o trabalho de campo na ONG "Olhos d'água", no bairro Mocoquinha e no Parque Ecológico São Sebastião, no bairro Vila Naufel. Destacamos que as referidas dificuldades são também sinalizadas no estudo de Rozin (2019) que realizou ações do projeto em município de Pato Branco-PR e no estudo de HRCHOROVITCH, (2019), que realizou ações do mesmo no município de Itapejara D'OestePR.

Em Marília-SP, o trabalho de campo foi realizado com apoio de alunos da graduação de Ciências Sociais e o "[...] financiamento da UNESP, por meio de editais de apoio à 
Extensão Universitária (PROEX - Pró-Reitoria e Extensão), de Formação de Professores (Programa Núcleos de Ensino da UNESP, PROGRAD - Pró-Reitoria de Graduação da UNESP)" (CLAUDINO; FERNANDES; GRAZZINI, 2019, p. 470). Desta forma, o transporte foi pago por meio da universidade.

Isto posto, embora dois professores tenham explicitado desafios e dificuldades, todos eles conseguiram realizar as saídas da sala de aula para desenvolver o trabalho de campo. Etapa fundamental para o pleno desenvolvimento do projeto Nós Propomos!. Em Ibitinga-SP, os alunos e a professora verificaram o entorno da escola e os bairros dos próprios alunos.

Em Serrana-SP, houve destaque para dois bairros. Em Marília-SP, os trabalhos de campo foram feitos na área do entorno da UNESP e em um assentamento rural. Em MococaSP, houve a investigação do entorno de uma escola privada. No mesmo município, na escola pública, houve a investigação de um Centro de Saúde, em um bairro de alta vulnerável social.

Neste sentido, observamos que houve ações de pesquisa para o levantamento dos problemas locais, o entendimento desses problemas para a possibilidade de proposição de soluções para esses problemas, pelos alunos. A “[...] a pesquisa, é então a possibilidade de cada aluno poder avançar conforme são seus interesses e suas capacidades, buscando as informações que precisa, assim como verificando as bases para dar conta de compreender estas informações" (CALLAI, 2004, p.7)

Notamos, portanto, que mais dois dos princípios do projeto foram atendidos e realizados com êxito, pelos cinco professores participantes. De acordo com Claudino (2019a, p. 39 grifo nosso),

2. Simplicidade metodológica - o Projeto é muito simples, na sua metodologia. As suas fases essenciais são a identificação de problemas locais, a realização de trabalho de campo sobre os mesmos, a apresentação de propostas de intervenção.

3. Investigação - Esta é uma dimensão com uma relevância crescente, existindo já diversos textos sobre o projeto e teses em curso sobre o mesmo. A recolha de informação empírica e a reflexão sobre a mesma é, neste domínio, fundamental.

A ideia de simplicidade metodológica está ligada a ser aplicável, de forma dinâmica e flexível a distintas realidades, tendo em vista, um coeso processo educativo, ou seja, não necessariamente por ser "fácil" e/ou "simples" de ser realizado. Diante disso, admitimos a necessidade de um planejamento prévio das ações para a execução do projeto com as turmas e uma constante reflexão sobre as práticas pedagógicas. 
Os professores promoveram a prática da investigação com os alunos com a saída da sala de aula, na forma de trabalho de campo nos bairros e no entorno da escola. Essa investigação foi sistematizada na volta para a sala de aula. Assim, foi avaliada pelos alunos e professores participantes e foram apresentados resultados para as unidades escolares. Destacamos que, das práticas realizadas, quatro ocorreram no espaço urbano e somente em uma, em Marília-SP, o espaço rural foi focalizado, além do urbano. Os alunos puderam conhecer um assentamento, na zona rural de Gália, município próximo a Marília-SP.

Isto posto, sob a ótica dos professores participantes, a realização da etapa da saída da sala de aula, por meio do trabalho de campo, foi significativa, para as aprendizagens dos alunos participantes. De formas e modos distintos em cada localidade, a fala dos professores explicita tal aspecto

[...] os alunos "encontram" para a cidade, olham a cidade e o espaço geográfico local de uma maneira mais atenta, isso já é significativo para eles, porque ele [o aluno] vai levar os problemas que já foram debatidos em sala de aula para a realidade vista e ressignificá-los [...] Porque antes da gente sair da sala de aula, nós discutimos o que são problemas urbanos, que tipos de problemas que tem no seu bairro, na sua cidade, e aí quando eles vão a campo eles identificam isso [...] Mostrar para os alunos que isso é muito importante, que ele participe da construção do lugar onde ele vive. (Valquíria)

[...] quando as saídas acontecem é muito mais significativo a aprendizagem porque é vivenciado aquilo. Por meio do projeto nós propomos! (que percorreu o bimestre inteiro) eu observei muitas aprendizagens acontecerem e não foi eu que falei, foram eles que falaram [...]. Eles [os alunos] que produziram o próprio conhecimento. Eu acho que essa é a palavra ideal, os alunos produziram o próprio conhecimento, eles desenvolveram certa autonomia. (Sonara)

O que eu acho que é notável é quando ele [ o aluno ] volta do campo, ele começa a escrever o relatório [...] aquilo também é um processo de síntese [...] que é insubstituível, então eu percebo que a organização dos alunos com a escrita, a dimensão da ligação da teoria com a prática, com os alunos que vão ao campo depois voltam "transformados" [...] isso fica evidente para mim, pois o processo da escrita e a participação deles enriquece muito. (Gabriel)

[...] depois da primeira saída na sala de aula, por exemplo fazer entrevista no sistema de saúde, foram conhecer as ONGS, eles começaram a ver coisas interessantes sobre os assuntos que eles tinham escolhido [...] fazendo pesquisas que eles não pensavam, observando o funcionamento da estrutura da saúde pública que eles não conheciam. Acredito que as aprendizagens foram 
significativas sim, nesse sentido, de ver como é possível interagir como cidadão, quais são seus direitos, quais são as instituições que você tem que se relacionar, como as coisas funcionam [...] eu acho que essa visão do todo, foi muito importante na formação dos alunos. (Rosani)

[...] eles [os alunos] saíram da "zona de conforto" que eles têm no cotidiano e participaram de um trabalho de campo no qual eles pesquisaram e tiveram que tomar decisões [...] então, a aprendizagem foi muito significativa, entre eles, pois conheceram a realidade ao entorno da escola e sobre problemas relacionados à saúde municipal. Então essas saídas trouxeram, para eles, um conhecimento enorme da realidade local e a "lugar" deles frente a estes problemas. (Américo)

Pelo exposto, os cinco participantes explicitam que entenderam que contribuições significativas ocorreram aos alunos. Esse entendimento passa, necessariamente, pela compreensão do lugar desses alunos. Este lugar é o espaço vivido e de experiências diárias que eles estabelecem com eles mesmos e com o outro, por meio de suas relações sociais. Os alunos tomaram conhecimento e identificação dos problemas dos seus bairros e se sua cidade. Assim, observam, participaram, pesquisaram o local com afirmam Valquíria, Sonara e Rosani.

A ação da saída a campo também possibilitou a produção do próprio conhecimento e o reconhecimento enquanto cidadão ativo na comunidade como afirma Gabriel. Neste sentido, as práticas dos professores foram “[...] capazes de articular a formação do sujeito com identidade e reconhecendo o seu pertencimento, com o trabalho cognitivo capaz de situar o aluno no contexto de uma produção intelectual pela humanidade" (CALLAI, 2004, p.9).

Os cinco professores destacam, também, que o que foi discutido na sala de aula tem maior significado para os alunos com a saída da escola. Assim, a localidade em que os alunos se encontram pode ser problematizada por meio de uma investigação e de um "olhar crítico" para o entorno e os bairros. Eles saíram da "zona de conforto", como afirma o professor Américo, e conseguiram interagir e conhecer as instituições, como afirma a professora Rosani.

As falas dos cinco professores estão em consonância com o valor do lugar no ensino de Geografia (CALLAI, 2004; CAVALCANTI, 2019). Isto posto, citamos o trabalho de Tazinasso e Francischett $(2019$, p. 8), que relaciona o projeto Nós Propomos! à valorização do lugar como forma de contribuição à educação geográfica. As autoras afirmam que

Os estudantes precisam olhar para a realidade estudar as representações, o contexto do lugar. Logo, isto se concretize no processo de aprendizagem 
partindo da particularidade, consequentemente, construindo identidade de pertencimento e o pensar e agir por meio da cidadania.

Além disso, conheceram melhor os problemas urbanos locais, como afirma a professora Valquíria, para poderem relacionar a teoria com a prática de dada realidade, como afirma o professor Gabriel e, posteriormente, construírem, de forma autônoma e sistemática, o conhecimento científico na proposição de intervenções locais, como afirma a professora Sonara.

Notamos que os relatos sobre as práticas desses professores alinham-se a um olhar significativo para a cidade, como espaço de interação social, aprendizado e dinamismo. Desta forma, é necessário viver a cidade, dialogar com o seu território, realizar diversas leituras e agir sobre ela de forma responsável (CELY RODRÍGUEZ; MORENO LACHE, 2015).

Observamos que o local foi valorizado por meio do trabalho de campo realizado, em uma das etapas do projeto, e pôde promover uma apreensão concreta da dada realidade, em conjunto com as investigações, mediadas pelos professores. Tais práticas vão ao encontro das ideias de Claudino, Fernandes e Grazzini (2019a, p. 469), que destacam que a “[...] investigação sobre os arredores da escola e as comunidades locais possibilitam a análise mais objetiva e problematizadora da relação do local, possibilitando a construção de conceitos geográficos".

Sob a ótica dos professores participantes, a importância do ensino e da investigação do entorno, como componente do lugar de vivência do aluno, é uma forma de promover uma aprendizagem significativa aos alunos. Neste sentido, admitimos a ideia presente no trabalho de Palacios Mena e Fernandes (2019, p. 221, grifo nosso) do entorno

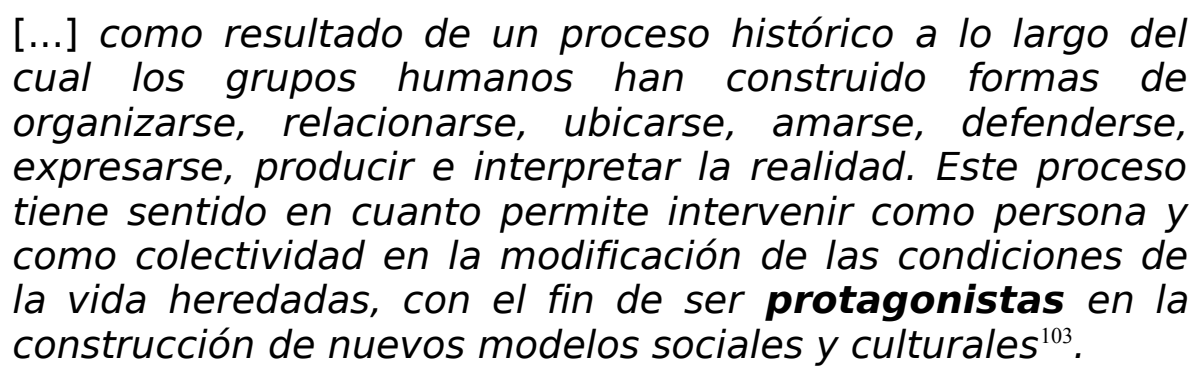

Destacamos que o conhecimento do meio social, ou também chamado entorno, pelo ser humano, coloca-o como um possível agente de mudanças. Neste sentido, a apropriação, a

\footnotetext{
103“"...] como resultado de um processo histórico por meio do qual os grupos humanos criaram maneiras de organizar, relacionar, localizar, amar, defender, expressar, produzir e interpretar a realidade. Esse processo faz sentido na medida em que permite intervir como pessoa e como comunidade na modificação das condições de vida herdadas, a fim de ser protagonista na construção de novos modelos sociais e culturais" (tradução nossa).
} 
identificação e a intervenção dos alunos sobre o seu entorno permite uma educação focada na cidadania, no sentido de promover mudanças para a melhoria da qualidade de vida da população.

Isto posto, podemos notar com as cinco práticas desenvolvidas que houve a valorização do lugar e do entorno como forma de pensar a cidade, seus problemas sociais e, posteriormente, possíveis propostas para uma intervenção do lugar. Essa valorização do local alinha-se a um entendimento amplo e significativo para aprender a cidade. Assim, Cely Rodríguez e Moreno Lache (2015, p. 118, grifo nosso) afirman

De la ciudad se aprende desde el análisis de las vivencias que tienen sus habitantes, los profesores y los estudiantes, los espacios vividos en la ciudad, el barrio, el conjunto residencial, el parque, la calle, el colegio donde estudian, el lugar donde han crecido, su entorno imediato ${ }^{104}$.

O conhecimento, de forma científica e sistematizada, desse entorno imediato promoveu, aos alunos, sob a ótica dos professores, uma identificação com o espaço vivido e um sentimento de pertencimento, ao estudar os problemas sociais do bairro.

Em Ibitinga-SP, desenvolveram-se práticas pedagógicas voltadas para a cidadania, os alunos pensaram e propuseram intervenções sobre os espaços públicos de lazer, nos anos de 2018 e 2019. Essas práticas tiveram como foco, o local, o entorno da escola e os bairros de vivência dos alunos (MENEGHESSO; CARVALHO FILHO; LASTÓRIA, 2019), alinhandose a uma perspectiva de identificação e valorização desses espaços como sendo componentes essenciais para o convívio coletivo (PORTELA; ALENCAR, 2019).

Em Serrana-SP, as práticas ocorreram no entorno da escola e nos bairros habitados pelos alunos (Quadro 9), sendo as propostas feitas com base nos problemas levantados pelos próprios alunos. A professora Sonara salienta que a experiência realizada evidenciou que a observação foi estimulada, e o entendimento da localidade vivida indicou um estímulo para a prática cidadã.

\footnotetext{
104 “A cidade é aprendida a partir da análise das experiências de seus habitantes, professores e alunos, os espaços vividos na cidade, o bairro, o complexo residencial, o parque, a rua, a escola onde estudam, o local onde cresceram, seu ambiente imediato" (tradução nossa).
} 
[...] os alunos aguçaram o seu olhar pelo caminho que eles passam todos os dias para ir para a escola, mas nesse olhar eles, levantaram alguns problemas da localidade, [...] eles tiveram que entender o que é o local, um problema do local que eles passaram a perceber e refletir [...] eles fizeram isso depois da apresentação das duas salas junto [...] com isso, desenvolveram um olhar problematizador para o espaço. Esse olhar mais aguçado para a questão espacial na localidade (de se perceberem como cidadãos) e que eles podem praticar a cidadania todos os dias. (Sonara)

No caso de Marília-SP, sob a ótica dos professores, as práticas ressignificaram a importância do lugar e auxiliaram a reflexão sobre os problemas da comunidade em que vivem (LAVRATTI, 2018), (LAVRATTI; FERNANDES, 2019). Diante disso, Claudino, Fernandes e Grazzini. (2019a, p. 474) afirmam que o projeto em Marília envolveu

A colaboração entre os integrantes, as trocas de experiências, a realização de trabalho de campo e a atenção à escala local, como espaço privilegiado de investigação e ensino, sem perder uma visão multiescalar, atribuem ao projeto unicidade e, ao mesmo tempo, diversidade, na formação para a cidadania territorial.

No caso de Mococa-SP, Rigamonte (2019, p. 2870) admite que "[...] independente da escola o entusiasmo dos alunos para se envolverem com o projeto e saírem da sala de aula para investigarem o seu entorno e seus problemas foi um grande facilitador deste processo".

As falas dos cinco professores, portanto, vão ao encontro à valorização do trabalho de campo como ação promotora de aprendizagem significativa em um ensino, não tradicional, de Geografia. A investigação do entorno e do local, por meio do trabalho de campo, constitui uma prática inovadora por dar relevância aos saberes cotidianos dos alunos e torná-los conhecimentos escolares para a vida e, assim, desenvolver a cidadania nestes jovens (PALACIOS MENA; FERNANDES, 2019).

Isto posto, cabe ressaltar que as práticas analisadas estão ligadas a uma educação geográfica que "[...] interessa conhecer o mundo interligando os problemas do lugar com as demandas globais" (CALLAI, 2010, p. 22). Neste sentido, os temas e problemas sociais investigados pelos alunos participantes estão presentes no local e no global, de distintas configurações.

Quadro 8 - Dados relativos à saída da sala de aula 


\begin{tabular}{|c|c|c|}
\hline Valquíria & $\begin{array}{l}\text { Identificação dos } \\
\text { problemas. }\end{array}$ & $\begin{array}{l}\text { Bairros Centro e Maria Luiza II (2018) } \\
\text { Bairros Centro e Vila Romana II (2019) }\end{array}$ \\
\hline Sonara & Explorarem a localidade. & Bairros Cidade de Belém e D. Pedro (2018) \\
\hline Gabriel & $\begin{array}{l}\text { Saída e observação do } \\
\text { campo. }\end{array}$ & $\begin{array}{l}\text { Entorno da escola e área de preservação na UNESP } \\
\qquad \text { (2017) } \\
\text { Assentamento Luiz Beltrame (município de } \\
\text { Gália/SP) (2018) }\end{array}$ \\
\hline Rosani $^{105}$ & $\begin{array}{l}\text { Interação com o espaço } \\
\text { geográfico. }\end{array}$ & $\begin{array}{l}\text { Entorno da escola nos Bairros Conjunto } \\
\text { Habitacional Gilberto Rossetti e Parque Ecológico } \\
\text { São Sebastião no bairro Vila Naufel. } \\
\text { Entorno da escola no bairro Conjunto Habitacional } \\
\text { Gilberto Rossetti e a ONG "Olhos d'água”, no } \\
\text { bairro Mocoquinha. }\end{array}$ \\
\hline Américo & $\begin{array}{l}\text { Saída e observação do } \\
\text { campo. }\end{array}$ & $\begin{array}{l}\text { Casa do Adolescente "Dr. Vinicius Ghirlinzoni } \\
\text { Monsores" ADOLEV, no bairro COHAB II. } \\
\text { Grupo TUMM "Todos unidos para mudarem o } \\
\text { mundo", no bairro Jardim Chico Piscina. }\end{array}$ \\
\hline
\end{tabular}

Fonte: elaborado pelo autor

Notamos que as ações fundamentais, sob a ótica dos participantes, foram atividades de observação, análise e interação dos alunos com o espaço geográfico, por meio da identificação dos problemas locais. Com base nas informações presentes no quadro 8, podemos apontar que, de modos distintos, com tempos e maneiras de execução, os cinco professores participantes utilizaram o trabalho de campo como forma de saída da sala de aula, para a realização de uma das etapas do projeto. Os focos desta aplicação foram o entorno da Escola e bairros adjacentes. Eles contaram com o auxílio da equipe gestora e seguiram os protocolos de saída de alunos das unidades escolares.

Os bairros estudados foram elegidos pelos próprios alunos, ou seja, ao levantar os problemas sociais, em conjunto com os professores, os alunos escolheram os temas e os locais para investigam. Desta forma, podemos evidenciar indícios que a autonomia (FREIRE, 2014) dos alunos foi desenvolvida.

\footnotetext{
${ }^{105}$ Apresentamos os dados da prática desenvolvida na escola privada em Mococa/SP, coordenada pela professora Rosani em duas turmas do $8^{\circ}$ ano.
} 
Admitimos o trabalho de campo como uma das fases do estudo do meio (PONTUSCHKA, 2004), (LOPES; PONTUSCHKA, 2009, 2010), uma vez que é uma ação realizada em várias etapas. A saber: o encontro dos sujeitos sociais, a opção pelo espaço e tema a serem estudados, a definição dos objetivos e planejamento, o trabalho de campo, a sistematização dos dados coletados, avaliação e divulgação dos resultados (LOPES; PONTUSCHKA, 2010).

As etapas foram pautadas pela observação dos alunos. Neste sentido, no estudo do meio, podem ser aplicadas duas formas de observação, de forma isolada ou simultânea, a saber "[...] a observação simples: forma espontânea de observar [...] e a sistêmica: feita com planejamento prévio, delimitação dos objetivos, levantamento de hipóteses e construção de instrumentos de observação para que os dados possam ser registrados" (BITTENCOURT, 2005, p. 282 apud BOSCOLO, 2007, p. 55).

Mediante esses apontamentos, consideramos que a complexidade de dada realidade pode ser melhor apreendida através do meio local, por meio de observação constante dos alunos durante todo o processo educativo do estudo do meio. Para complementar, tal aspecto, Lopes e Pontuschka (2010, p. 38, grifo nosso) lembram-nos que

Deve haver a preocupação ética e política de comunicar às comunidades,
aos homens e mulheres que residem nos lugares estudados e pesquisadores,
os resultados dessa atividade $[\ldots .$.$] a organização do estudo do meio rompe, de$
certa forma, com uma maneira cristalizada de ser da Escola e possibilita
formas de ação que permitem a professores e alunos exercer um papel
mais ativo no processo de ensino-aprendizagem [...] uma atividade
curricular que visa a estimular os hábitos de pesquisa [...].

Os itens destacados na citação anterior estão relacionados com alguns princípios do projeto Nós Propomos! no que se refere à: investigação, cidadania territorial, construtivismo, valorização de diferentes competências e à divulgação (CLAUDINO, 2019a, 2019b).

Neste sentido, os cinco professores participantes, mesmo que não explicitado, desenvolveram o estudo do meio, promovendo a investigação do local, com os temas escolhidos pelos alunos. Houve um processo coeso de ensino por meio do projeto que abrangeu: uma preparação com aulas teóricas, uma saída da sala de aula (na forma de trabalho de campo), o retorno para a sala de aula (com debates e sistematização dos dados das investigações) e, divulgação das conclusões na Escola e, em dois municípios, para o poder local.

Consideramos, portanto, sob nossa ótica, dois avanços do projeto no estado de São Paulo. O primeiro avanço é a possibilidade de promover o estudo do meio e do trabalho de 
campo nas práticas pedagógicas dos cinco professores participantes desta investigação. Neste sentido, a promoção de tais ações proporcionou aprendizagens significativas, aos alunos, quanto ao olhar e intervir no território local. Admitimos que semelhante conclusão chega o estudo sobre a realização do Projeto Nós Propomos! no Paraná (PR). Segundo Halaszen (2020, p. 115),

[...] os estudantes, quando convidados a refletir sobre o seu cotidiano, passaram a olhar sobre o território de uma forma mais atenta e crítica, a qual favorece a formação para a cidadania, pois é se identificando como sujeito parte do território que passa a agir na busca da melhoria.

Um segundo avanço foi o estabelecimento de parcerias (figura 17) entre instituições públicas (USP e UNESP) e privada (FUNVIC) e o constante diálogo e compartilhamento de experiências entre seus responsáveis e os professores participantes da investigação para promover o projeto Nós Propomos! para os alunos (cerca de 575, envolvidos), como apresentado no quadro 5.

Salientamos, no entanto, que a realização das referidas ações apresentou desafios e limites. Um deles diz respeito ao número de alunos que não pode participar na escola pública de Mococa-SP. Notamos pelas falas dos professores, problemas também com relação ao deslocamento das turmas.

A professora Rosani e o professor Américo explicitaram as dificuldades que tiveram para conseguir transporte para os alunos da escola pública de Mococa-SP. A professora Sonara e a professora Valquíria não tiveram problemas com o transporte já que as atividades foram no bairro da escola e nos arredores. O Professor Gabriel, por meio da parceria com a UNESP, conseguiu ônibus para levar os alunos nos trabalhos de campo.

Outro desafio refere-se a dificuldade apontada por alguns participantes para envolver outros professores nas unidades escolares dispostos a realizar o projeto de modo integrado e multidisciplinar. Em Ibitinga-SP, com a professora Valquíria, e em Serrana-SP, com a professora Sonara, parcerias foram efetivadas com outros professores. Em Marília-SP, o professor Gabriel contou com o apoio de graduandos de Ciências Sociais da UNESP, em parceria com o CPEA. Em Mococa-SP, a professora Rosani e o professor Américo não conseguiram estabelecer parcerias com os professores da escola privada e da pública.

\subsection{Contribuições do projeto para os professores e para os alunos}


Nesta subseção analisamos elementos que indicam as contribuições do projeto Nós Propomos! para os professores e para os alunos, sob a ótica dos professores. Além disso, tecemos considerações sobre a etapa final do projeto, que é a divulgação, ocorrida nas escolas, em alguns casos, ao poder público local.

Temos, ao final, um balanço (quadro 9) dos avanços e desafios do projeto Nós Propomos! no estado de São Paulo e a resposta para nossa questão de investigação. A professora Valquíria admite que, sob sua ótica, o projeto alinha-se a sua visão de Educação, crítica e participativa, como forma de ação política para a promoção de práticas de cidadania.

Valquíria admite ânimo e esperança no projeto por valorizar o professor e tornar os alunos ativos na sociedade e na proposição de soluções para os problemas do seu cotidiano. Além disso, ela relata a fala de uma aluna para exemplificar a ideia de o projeto estar alinhado como ação política.

[...] o projeto reafirma para mim uma questão que faz parte da minha prática que é a importância da participação dos alunos no lugar onde ele vive [...] o projeto talvez tenha sido o projeto que mais contribuiu ao longo da minha carreira de uma maneira que isso tenha sido sistematizada durante uma aula, durante o desenvolver do projeto, que os alunos são ativos, que podem ter o seu protagonismo, estender para a vida deles fora da escola, como cidadãos, como membros de uma sociedade [...] Eu acho que ficou claro para esses alunos, eu não sei se todos os alunos puderam ver que tudo é uma ação política [...] que o que eles estavam falando era uma ação política e que política não é só uma questão negativa, é você inserido num mundo, na sociedade em que você vive, na coletividade. (Valquíria)

[...] participação política, mas isso ficou muito claro para mim no dia que uma aluna tinha que me entregar as entrevistas [...] todos levaram duas entrevistas e tinham que retornar com elas, a aluna veio para mim e falou assim: "professora, eu não fiz a entrevista" aí eu perguntei: "por que que você não fez a entrevista?" e ela falou assim: "porque a minha religião não permite que eu me envolva com política" ai eu falei: "qual é a sua religião?" "Eu sou testemunha de Jeová" aí eu perguntei: "Então isso é política o que estamos fazendo?". "É professora, nós estamos vendo o que os políticos fazem ou não na nossa cidade" [...]. (Valquíria)

O projeto correspondeu aos anseios da professora por um ensino de Geografia inovador, no sentido de promover a participação social e política dos alunos. Esta participação 
é também feita pela ocupação do espaço público, como praças e outros espaços de lazer, pela própria população e pelos alunos (CARVALHO FILHO, MENEGHESSO, CARNIEL, 2020).

A presença do diálogo marcou a experiência da professora Valquíria; os alunos e ela interagiram constantemente para elaborar as propostas de ação para serem apresentadas na Câmara Municipal de Ibitinga-SP. Neste sentido, Freire (2001, p. 29-30) admite que a Escola, com seus professores e projetos, deve "[...] inquietar os educandos, desafiando-os para que percebam que o mundo dado é um mundo dando-se e que, por isso mesmo, pode ser mudado, transformado, reinventado [...]".

A professora Sonara admite que a realização do projeto também correspondeu a seus anseios como docente por um ensino inovador e voltado para a ação dos alunos, como protagonistas de sua realidade local. Para Sonara, o projeto desenvolveu nos alunos conceitos geográficos por meio do trabalho de campo, dos debates e da proposição de soluções para os problemas locais.

[...] correspondeu ao que eu penso sobre Educação e fez meus olhos brilharem [...] viu uma chance maior do meu aluno gostar e aprender de Geografia por um método inovador que faz dele [o aluno] um protagonista, então, não sou eu que vou fazer o aluno aprender aquilo, o aluno vai aprender na prática, ele vai construir esse conhecimento na prática [...]. (Sonara)

Segundo Vlach (2007), os conteúdos geográficos são decisivos para a compreensão dos problemas do mundo contemporâneo, muitos dos quais estão ligados à convivência social no seu sentido mais amplo, a partir do reconhecimento dos modos em que se reproduzem espacialmente e socialmente. Neste sentido, para a professora Sonara, o projeto alinha-se à ideia de uma educação geográfica voltada para a cidadania, na medida em que o projeto desenvolve conceitos geográficos de forma inovadora.

Sob a ótica de Sonara, os alunos foram agentes do próprio conhecimento, de suas ações e decisões coletivas, ao pesquisar, ao debater e ao propor, de forma conjunta, as possíveis soluções dos problemas ao poder local. Ela destaca também que a ideia de patrimônio público, como bem comum e coletivo, foi refletida e apreendida, de fato, pelos alunos 
[...] eles entenderam que as duas salas unidas, foi melhor para conseguir uma solução. É o coletivo unido, como um meio para chegar no poder público e pressionar esse poder por melhorias sociais [...] foi mais adequado do que uma pessoa sozinha não consegue nenhuma resposta de imediato, eles juntos conseguiram várias respostas para várias coisas que eles tinham levantados e conseguiram e o que um dos problemas que foram expostos fosse resolvido [...] eles [os alunos] se perceberam como cidadãos, eles entenderam que algumas ações, por parte do poder público, são ineficazes e quem tem que brigar por alguma coisa para seja feita é o próprio cidadão. (Sonara)

Neste sentido, foram relatados, também, indicadores de mudanças de comportamentos que os alunos obtiveram, durante e após a realização do projeto, como, por exemplo, ouvir e ser ouvido, responsabilidade nas pesquisas e divulgação dos resultados. Reforça, também, a aprendizagem que o projeto proporcionou, como um "laboratório", na prática, das responsabilidades da passagem da vida da adolescência para a vida adulta.

Sob a ótica da professora Sonara, uma ressignificação do ensino de Geografia, foi possibilitada de modo muito coerente com a fala do professor Sérgio Claudino. A saber: “[...] o desenvolvimento de novas competências, a descoberta (ou redescoberta) do meio local, um renovado olhar sobre a disciplina de Geografia e, enfim, afirma-se a convicção de que o projeto promoveu o desenvolvimento de uma cidadania ativa" (CLAUDINO, 2014, p. 8).

O professor Gabriel admite que, para ele, o projeto trouxe ânimo e valorização da profissão docente. Além disso, possibilitou a realização de um ensino de Geografia significativo no espaço escolar e uma "revitalização" nas suas práticas pedagógicas, tanto em sala de aula, como por meio do trabalho de campo realizado. Além disso,

[...] o projeto trouxe uma organização e planejamento do campo, o levantamento dos recursos, o funcionamento dele [...] para mim, enquanto professor, é poder tornar o meu aluno apto a tomar decisões para sua vida e sua comunidade. (Gabriel)

O projeto permite ressignificar a prática docente ao dar a possibilidade de alinhar-se ao que muitos docentes acreditam ser importante para a Educação. No caso, para o professor Gabriel, foi a importância de tornar o campo notável e amplamente significativo para seu aluno. Desta forma, sob a ótica do professor, o próprio professor e os alunos podem tomar decisões sérias e responsáveis no cotidiano vivido. Além disso, sob a ótica do professor 
Gabriel, os alunos olham a sua realidade cotidiana, de forma crítica, e intervêm nos problemas sociais locais

[...] é um contato que faz com que ele entenda que existem diversas formas de viver o mundo que está fora da escola e que a escola pode preparar para conseguir fazer isso, é trazer o nosso aluno para uma realidade que o transcenda a que ele vive, que consiga levar ele ter o contato com outras realidades, para que ele entenda que exista uma grande realidade, que há várias interpretações disso [...] o projeto foi trazendo essa ideia do aluno reconhecer o problema, do aluno conseguir procurar uma solução para aquele problema, colocar em prática a solução para aquele problema, acho que isso, sem dúvida, torna o aluno mais autossuficiente na sociedade que a gente vive politicamente.

(Gabriel)

Observamos que a ideia da promoção da autonomia por meio do desenvolvimento da tomada de decisões conscientes, pelos alunos, é uma grande contribuição do projeto. Essa autonomia é ter ações políticas e sociais em prol de si e do coletivo.

Destacamos que o referido projeto alinha-se a uma pedagogia problematizadora, que tem o "[...] esforço de propor aos indivíduos dimensões significativas de sua realidade" (FREIRE, 2004, p. 134), uma problematização das instituições e dos problemas sociais encontrados pelos alunos, que podem apresentá-lo para a comunidade escolar e para o poder público local.

A professora Rosani admite que, para ela, o projeto promoveu aprendizagens de formação continuada em práticas pedagógicas voltadas para a cidadania, além de uma ressignificação modo de pensar o ensino, a pesquisa e a extensão universitária.

E, para minha formação, essas vivências [como mediadora do projeto], na verdade, constroem conhecimentos de fato no indivíduo, como cidadão e contribui para a formação dele [...] ver como é possível os alunos interagirem como agentes ativos na sociedade, quais são seus direitos e quais são as instituições que podemos recorrer para pesquisar e tratar de determinados problemas sociais [...]. Eu acho que essa visão do todo foi muito importante nessa formação. (Rosani)

Para Rosani, o projeto a auxiliou na promoção de relações de interação mais profundas entre ela e os alunos. O projeto permitiu conhecer e construir conhecimentos constantes sobre as relações sociais e as instituições, além de ter sido peça essencial de investigação da sociedade. Para a professora Rosani, os alunos desenvolveram a ideia de interação social entre 
os seus pares e com o próprio professor de Geografia. O diálogo foi constante e as interações criaram maior respeito pelo professor e responsabilidade social para com a saúde dos próprios alunos e com o espaço escolar.

[...] é possível interagir enquanto cidadão, quais são seus direitos, quais são as instituições que você tem que se relacionar, como as coisas funcionam, eu acho que essa visão do todo foi muito importante nessa formação. [...] interagir, interessante quando você vê começando o projeto e no final você vê os próprios alunos interagindo, perguntando, falando sobre o assunto, então é sinal de que de fato ele vivenciou esse aprendizado, então ele se torna significativo nesse sentido. (Rosani)

Notamos que os alunos puderam dialogar com mais profundidade sobre os temas investigados e chegar a decisões pontuais sobre as propostas. Desta forma, a construção do conhecimento se deu por meio do diálogo. Neste sentido, o diálogo é a confirmação conjunta entre o professor e o aluno do ato de conhecer e pesquisar determinado objeto, assim focados, ambos podem despertar múltiplos olhares sobre o que for o estudo (FREIRE, 2014).

O professor Américo admite que, para ele, o projeto foi de grande relevância para trabalhar um ensino de Geografia inovador e focado no aluno e na localidade "problematizada". Ele admite que houve um aprendizado profissional e pessoal significativos com relações estabelecidas com os alunos com a professora Rosani, como mediadora do projeto. Além disso, sob sua ótica, os alunos aprenderam a tomar decisões em prol da sua qualidade de vida e de saúde pessoal e, também, para o coletivo, por meio de instituições ligadas a saúde municipal. Destacamos o relato da aluna que, por meio do projeto, pôde apropriar-se de ferramentas legais e tomar a decisão de ajudar seu irmão

[...] um dos casos de uma aluna, que tem um irmão que tem uma necessidade de fazer uma operação, devido ao fato de ter caído de moto e ter tido uma fratura [...] e por quatro meses praticamente ficou sem ser atendido e tudo mais e através do projeto ela teve um maior conhecimento do que é a secretaria de saúde do município e o que ela [ secretaria] poderia lhe proporcionar [...] ela procurou os órgãos competentes e conseguiu mostrar a real situação do irmão dela [...] assim conseguiu realizar a operação do irmão [...]. (Américo)

O projeto contribuiu para discussão sobre a saúde do adolescente, ou seja, possibilitou que eles olhassem e percebessem o próprio corpo e sua responsabilidade para com ele. Desta 
forma, fica explicitado que o projeto proporcionou, para os alunos, uma apropriação dos instrumentos legais para o funcionamento da cidadania, e, assim, deixam de ser um cidadão consumidor multifacetado (SANTOS, 2004).

Com base nessas falas dos professores, observamos que o projeto promoveu um ensino de Geografia significativo, pois foram realizadas interações permanentes entre os professores e os alunos durante o desenvolvimento do projeto. Assim, houve a elevação dos alunos a "“...] patamares superiores do ponto de vista da abstração e da consciência sobre a importância do conhecimento Geográfico para a vida como ser humano e como cidadão participante deste mundo complexo" (PONTUSCHKA; PAGANELLI; CACETE, 2009, p.77). As práticas puderam despertaram a consciência da importância da Geografia na vida cotidiana dos alunos para que eles se entendessem como cidadãos.

Salientamos mais dois princípios do projeto que foram efetivados por meio das práticas pedagógicas:

1 - Cidadania territorial - o Projeto promove uma cultura de intervenção cidadã no território. O seu principal output, mais do que as propostas concretas dos alunos, é mesmo a atitude olhar criticamente para a comunidade, na perspectiva de contribuir para a sua melhoria.

8 - Valorização de diferentes competências - Desde logo, o Projeto desenvolve competências de pesquisa, tratamento de informação e discussão de ações concretas de intervenção. Mas com concursos como de fotografia ou vídeo, promovem-se ainda outro tipo de competências entre os alunos. Estes concursos não são centrais no Projeto Nós Propomos!, mas constituem já um patrimônio do mesmo (CLAUDINO, 2019a, p. 39)

A cidadania territorial foi contemplada na medida em que a maioria dos alunos conseguiu elaborar propostas a partir das investigações dos problemas locais, com a mediação dos professores. Neste sentido, admitimos que o projeto abrange uma perspectiva que busca uma

[...] maior relevância à Geografia que se ensina, tornando-a mais interessante e mais atraente, promovendo aprendizagens significativas, trabalhando com conhecimentos integrados, abertos, que consideram a complexidade inerente à realidade, destacando-se a relação entre cotidiano, mediação pedagógica e formação de conceitos no desenvolvimento do processo de ensino/aprendizagem. (CAVALCANTI; SOUZA, 2014, p. 4)

A Geografia, e o seu ensino como relevância social (CAVALCANTI, 2019) para os alunos, é notável nas práticas desenvolvidas pelos professores. O lugar de vivência e o cotidiano dos alunos são aflorados nas pesquisas feitas pelos professores. Desta forma, há a promoção de aprendizagens significativas ao trabalhar com a dada realidade. 
$\mathrm{Na}$ etapa final, os trabalhos dos alunos foram apresentados nas unidades escolares e, em algumas escolas, para o poder público local. No caso, nos municípios de Ibitinga e Serrana foi possível apresentar os trabalhos para o poder público local. Cada caso teve um motivo específico. Em Ibitinga-SP, a professora Valquíria conduziu, juntamente com a professora de Língua Portuguesa, os alunos à Câmara dos vereadores para apresentarem as propostas. Os alunos apresentaram do plenário e, após isso, os vereadores fizeram comentários sobre as proposições, e elogiaram a ação educativa, com a garantia de averiguação do assunto problematizado. Segundo a professora Valquíria, os alunos sentiram-se cidadãos atuantes e responsáveis por exporem suas propostas de intervenção na localidade.

Em Serrana-SP, o vice-prefeito e o secretário municipal de infraestrutura assistiram as apresentações dos alunos na escola. A fala de Sonara explicita tal aspecto

[...] a reunião aconteceu no pátio $\mathrm{O}$ vice-prefeito levou o secretário da infraestrutura junto com ele e os alunos começaram a levantar vários questionamentos. Tudo envolvendo os problemas que eles tinham levantado, então eles não ficaram só em cima da questão do calçamento. Eles [os alunos] destacaram, principalmente, o problema do calçamento, mas na oportunidade, eles falaram de todos os problemas que eles tinham encontrado com as pesquisas. $\mathrm{O}$ vice-prefeito ouviu, falou bastante $\mathrm{e}$ colocou o seu secretário da infraestrutura para falar [...]. (Sonara)

A ida e a apresentação na câmara dos vereadores significaram uma prática da cidadania como relacionada à vida pública “[...], no sentido de se atribuírem significados ao que é público, aos temas da vida coletiva, aos espaços públicos” (CAVALCANTI, 2019, p. 210). Em ambos os casos, os alunos foram "ouvidos" por representantes do poder local. Houve um diálogo entre os alunos e os gestores municipais, em Ibitinga-SP e em Serrana-SP. Assim, admitimos que a cidadania pode estabelecer estratégias técnicas e humanas que ampliam o diálogo com os gestores públicos, a universidade e a comunidade (FREIRE, 2014).

Em Marília-SP, como destacado anteriormente, o projeto Nós Propomos! estava ocorrendo em conjunto com outros projetos ${ }^{106}$, dessa forma, não tinha como objetivo final levar os alunos na câmara dos vereadores. Desta forma, os trabalhos foram apresentados na escola para as outras turmas em formato de painéis (CLAUDINO; FERNANDES, GRAZZINI, 2019).

\footnotetext{
106 “O currículo de Geografia no Ensino Médio e as políticas de avaliação educacional: os conceitos de ambiente, cidade e campo nas provas do Exame Nacional do Ensino Médio", "Meio ambiente sob o olhar da mídia: a questão ambiental em Marília e região", Currículo de Geografia e práticas ambientais: a educação geográfica e o observatório do meio ambiente" (CLAUDINO; FERNANDES; GRAZZINI, 2019, p. 470).
} 
Em Mococa-SP, na escola estadual, o professor Américo afirma que não conseguiu finalizar o projeto. Na escola privada, a professora Rosani colocou que a apresentação dos trabalhos foi feita na escola. Em ambas as escolas de Mococa-SP, então, a articulação com o poder público local ficou comprometida, devido à problemas de corrupção e gestão municipal.

A professora Sonara destaca que a apresentação dos trabalhos dos alunos na escola foi feita no refeitório, com a presença de alguns professores e de outras turmas que estavam na escola. A professora enfatiza que não houve a participação de membros da comunidade escolar e de nenhum responsável, embora ela tenha convidado e divulgado a apresentação.

Sinalizamos que mais dois princípios do projeto foram atendidos (CLAUDINO, 2019a, 2019b):

7. Parcerias - o Projeto valoriza, desde logo, as parcerias entre a universidade e as escolas, mas um terceiro pilar fundamental desta parceria é o poder local, desde logo o dos municípios.

10. Divulgação - a divulgação das atividades do Projeto dá-lhe visibilidade e força. Além disso, mobiliza a própria sociedade civil para dar atenção às propostas dos alunos.

Os referidos princípios foram atingidos de forma parcial, uma vez que a parceria com o poder local nos municípios de Mococa-SP e Marília-SP não conseguiu ser finalizada, e nos municípios de Ibitinga e Serrana foi feita apenas a apresentação final do projeto para os representantes, ou seja, não ocorreu um diálogo constante entre a universidade, a escola, a comunidade e o poder local. Quanto à divulgação, ocorreu, também, de forma parcial, uma vez que somente em Ibitinga e em Serrana houve a divulgação para o poder local, enquanto em Mococa-SP e Marília-SP houve a divulgação somente dentro da Escola, com a participação de poucos responsáveis.

Observamos que um desafio para o futuro do projeto Nós Propomos! no estado de São Paulo é promover uma maior aproximação entre os responsáveis e a comunidade escolar antes, durante e após o projeto. A divulgação é um momento importante para a exposição dos alunos dos resultados para a comunidade escolar (alunos, responsáveis, gestores e funcionários).

Um segundo desafio para o futuro do projeto Nós Propomos! é que os alunos possam cumprir, de forma satisfatória e coletiva, todas as fases do projeto, contando com a apresentação ao poder público local. Em Serrana-SP, com a presença de dois representantes públicos na escola, e em Ibitinga-SP, com a ida dos alunos na câmara, ocorreu a divulgação 
para o poder público. Somente em um município, foi possível que os alunos ocuparem o espaço público de fala.

Destacamos que houve significativa mudança de comportamentos e pensamentos com o caminhar do projeto, sob a ótica dos cinco professores participantes. Segundo os cinco professores, houve aprendizagens novas na perspectiva cidadã para eles próprios e para os alunos. Nesse sentido, os professores apresentaram indícios que suas práticas tentaram superar práticas de um ensino tradicional de Geografia (CAVALCANTI, 2007).

Nos cinco casos, os professores participantes apontaram que os alunos comentaram que gostariam de continuar o projeto para os anos seguintes. Assim, os alunos, sob a ótica dos professores, apontaram que foi relevante em suas vidas, de formas variadas e intensidades distintas ${ }^{107}$. As evidências nas falas dos professores alinham-se à possibilidade de os alunos investigarem melhor a sua cidade, tornando-se atores da sua territorialidade para uma formação cidadã ativa (SOUZA; LEITE, 2018).

No caso de Serrana, a professora Sonara destacou a vontade dos alunos ( $3^{\circ} \mathrm{A}$ e $\left.3^{\circ} \mathrm{B}\right) \mathrm{em}$ continuar o projeto mesmo estando em outros espaços de Educação. Em consonância com a professora Sonara, temos o exemplo da fala da professora Valquíria, que afirma que

Muitos falaram que querem que o projeto continue no ano que vem, mas essas turmas não serão meus alunos no próximo ano, então eu não poderei dar continuidade ao projeto, mas eu percebi na fala dos 105 alunos que participaram do projeto, uma vontade de dar continuidade ao projeto. (Valquíria)

Destacamos na fala da professora Rosani a vontade dos alunos de continuação do projeto quando se remete à fala de um aluno.

[...] então todo mundo quer participar do projeto "Vamos continuar? Que rumo vai tomar?, vamos visitar mais alguém?, vai ter alguma palestra?” então eles se interessaram muito [...]. (Rosani)

Destacamos que os cinco professores participantes apresentaram indícios em seus relatos que explicitam, tanto para eles, quanto para os alunos participantes, que o projeto

$\overline{{ }^{107} \text { Estes dados foram apresentados em trechos das entrevistas pelos professores participantes. Nesta investigação }}$ não entrevistamos alunos participantes do projeto. 
renovou os olhares para as questões sociais. Neste sentido, o Projeto é, ainda, fundamental para a motivação dos alunos e dos professores. E, por último, para a visibilidade e notoriedade da Escola, quer na esfera local, nacional e, também, no âmbito internacional (CLEMENTE, 2019).

Notamos, com o caminhar da pesquisa, que esses professores participantes ressignificaram a Escola, na medida em que propuseram práticas de ensino não tradicionais para despertar uma consciência crítica-reflexiva nos alunos. Desta forma, alinhamo-nos às considerações de Pereira (2017, p. 110) de que

[...] a Escola deve pautar-se por uma ação concordante com as dinâmicas de transformação da sociedade e estar a par da realidade societal, e por outro lado, tendo a pretensão de encetar um percurso educativo que esteja [...] em consonância com o desenvolvimento de competências transversais, úteis à formação dos indivíduos-cidadãos. 
Quadro 9 - Resumo dos avanços e desafios do projeto Nós propomos! no estado de São Paulo.

\begin{tabular}{|c|c|c|c|c|c|}
\hline \multicolumn{2}{|c|}{$\begin{array}{c}\text { Relação do projeto com a } \\
\text { cidadania }\end{array}$} & \multicolumn{2}{|c|}{$\begin{array}{l}\text { Relevância da saída da sala de } \\
\text { aula }\end{array}$} & \multicolumn{2}{|c|}{$\begin{array}{l}\text { Contribuição do projeto para } \\
\text { os professores e os alunos }\end{array}$} \\
\hline Avanços & Desafios & Avanços & Desafios & Avanços & Desafios \\
\hline $\begin{array}{l}1 \text { - Promoção de } \\
\text { formação cidadã, } \\
\text { por meio de } \\
\text { indícios de falas e } \\
\text { comportamentos } \\
\text { de alunos, sob a } \\
\text { ótica dos } \\
\text { professores. } \\
2 \text { - Valorização de } \\
\text { investigações e } \\
\text { intervenções no } \\
\text { local e } \\
\text { ressignificação da } \\
\text { importância do } \\
\text { cotidiano na vida } \\
\text { pessoal dos } \\
\text { alunos. } \\
3 \text { - Superação de } \\
\text { um ensino } \\
\text { tradicional em } \\
\text { prol de um ensino } \\
\text { inovador, com } \\
\text { base em sujeito } \\
\text { crítico e } \\
\text { autônomo. } \\
4- \\
\text { Desenvolvimento } \\
\text { de um projeto de } \\
\text { ensino sobre } \\
\text { cidadania em um } \\
\text { sistema fechado } \\
\text { com currículo } \\
\text { pré-estabelecido. }\end{array}$ & $\begin{array}{l}1 \text { - Refletir e } \\
\text { mediar } \\
\text { situações de } \\
\text { vulnerabilidad } \\
\text { e social em } \\
\text { que se } \\
\text { encontra parte } \\
\text { dos alunos do } \\
\text { projeto para } \\
\text { que possam } \\
\text { participar de } \\
\text { forma efetiva } \\
\text { e finalizar o } \\
\text { projeto. } \\
2 \text { - } \\
\text { Desenvolver } \\
\text { formas mais } \\
\text { efetivas (um } \\
\text { trabalho } \\
\text { multidiscipli- } \\
\text { nar) os } \\
\text { professores da } \\
\text { turma para } \\
\text { maior } \\
\text { consolidação } \\
\text { do projeto }\end{array}$ & $\begin{array}{l}\text { 1 - Aplicação do } \\
\text { Estudo do meio } \\
\text { com sucesso. } \\
2 \text { - Promoção do } \\
\text { trabalho de } \\
\text { campo, com } \\
\text { certas } \\
\text { adaptações } \\
\text { locais, para } \\
\text { estudo do meio } \\
\text { local. } \\
3 \text { - } \\
\text { Estabelecimento } \\
\text { de parcerias } \\
\text { entre } \\
\text { Universidades e } \\
\text { escolas para o } \\
\text { desenvolvimen- } \\
\text { to do projeto. }\end{array}$ & $\begin{array}{l}1 \text { - Refletir e } \\
\text { promover uma } \\
\text { logística efetiva } \\
\text { para a } \\
\text { participação de } \\
\text { toda a turma } \\
\text { nos trabalhos de } \\
\text { campo. } \\
2 \text { - } \\
\text { Estabeleciment } \\
\text { o de parcerias } \\
\text { entre os } \\
\text { professores para } \\
\text { realizarem, em } \\
\text { conjunto, os } \\
\text { trabalhos de } \\
\text { campo com as } \\
\text { turmas. }\end{array}$ & $\begin{array}{l}1 \text { - } \\
\text { Ressignificaçã } \\
\text { o do papel do } \\
\text { professor na } \\
\text { formação } \\
\text { crítica e cidadã } \\
\text { dos alunos. } \\
2 \text { - Vontade } \\
\text { coletiva de } \\
\text { continuação do } \\
\text { projeto com } \\
\text { relativo ânimo } \\
\text { em relação à } \\
\text { leitura dos } \\
\text { problemas } \\
\text { locais. } \\
3 \text { - } \\
\text { Desenvolvime } \\
\text { nto do } \\
\text { dialogismo na } \\
\text { prática e } \\
\text { consequente } \\
\text { aprendizagens } \\
\text { simultâneas } \\
\text { entre } \\
\text { professores e } \\
\text { alunos. }\end{array}$ & $\begin{array}{l}1 \text { - } \\
\text { Necessidade } \\
\text { de promoção } \\
\text { de maior } \\
\text { quantidade e } \\
\text { qualidade da } \\
\text { presença dos } \\
\text { responsáveis e } \\
\text { da } \\
\text { comunidade } \\
\text { escolar na } \\
\text { etapa de } \\
\text { divulgação do } \\
\text { projeto. } \\
2 \text { - Efetivar a } \\
\text { participação } \\
\text { das turmas de } \\
\text { forma coletiva } \\
\text { na etapa final } \\
\text { do projeto, por } \\
\text { meio da } \\
\text { divulgação na } \\
\text { escola e no } \\
\text { poder público } \\
\text { local. }\end{array}$ \\
\hline
\end{tabular}

Fonte: elaborado pelo autor

Com base nos relatos feitos dos professores participantes e a partir da análise das entrevistas foi elaborado o quadro 9 para sistematizar os avanços e desafios do projeto Nós Propomos! no estado de São Paulo. Com base neste quadro podemos apontar algumas considerações em relação a cada uma das três categorias elencadas para esta investigação.

Com relação ao projeto e a formação para a cidadania foi possível promover uma cidadania ativa aos estudantes, mesmo com as dificuldades de cada realidade social, e despertar uma consciência de coletivo por meio de um ensino crítico-reflexivo. Ressaltamos, no entanto que é necessário refletir e mediar as inúmeras situações de vulnerabilidade social 
encontradas nos contextos escolares dos alunos e também promover formas mais eficientes de práticas multidisciplinares com os professores de outros áreas do conhecimento. Notamos, portanto, que a Geografia é reforçada como pilar disciplinar coeso em uma dimensão cidadã por projeto Nós Propomos! em detrimento de outras disciplinas escolares.

Com relação à relevância da saída da sala de aula foi comprovado que auxilia na aprendizagem significativa e na promoção da cidadania ativa dos alunos e que o estudo do meio é uma metodologia eficaz e estruturante para tais promoções. Existe, no entanto, questões a serem superadas como a logística e a eficiência da participação de toda a turma no trabalho de campo e o reforço das colaborações dos professores com o mesmo.

Com relação as contribuições do projeto para alunos e professores destacamos que foram significativas para ambos, uma vez que as práticas foram desenvolvidas em forma e uma rede colaborativa entre os professores e os membros dos grupos ELO e do CPEA, em um constante diálogo e compartilhamento de experiências exitosas e desafiadoras. Notamos, também, a construção do conhecimento geográfico de forma crítico-reflexiva em conjunto entre professores e seus alunos.

Desta forma, ambos citados, aprenderam e (re)significaram seu caminho formativo por meio da investigação de temáticas sociais variadas, que foram problematizadas, e com o envolvimento de alunos e professores diretamente na comunidade local. Apontamos, no entanto, que é necessário pensar e vivenciar o projeto de forma mais ampla pelos responsáveis dos alunos e pela comunidade escolar e também promover meios e fins para que a toda a turma consiga finalizar o projeto por meio da divulgação na escola e com/no o poder público local.

Destacamos que foram encontrados mais avanços do que desafios para o desenvolvimento e o futuro do projeto no estado de São Paulo, no entanto não podemos deixar de menciona-los como forma de reflexão das práticas pedagógicas. Admitimos que elencar esses desafios é assumir que projeto pode ser melhorado por seus coordenadores, pelos professores participantes e por futuros participantes. A intensão é trazer apontamentos pertinentes para uma (re) visão das práticas, da logística e dos papeis desempenhados pelos professores.

Desta forma, esta investigação servirá para futuros professores, gestores e, talvez, para a comunidade escolar traçar diretrizes e planejamento de ações mais pontuais para desenvolver o projeto em unidades escolares do estado de São Paulo e também do Brasil e pela ibero-américa. 
Diante do exposto, o objetivo central do presente trabalho sobre o levantamento e caracterização as práticas pedagógicas dos professores no "Projeto Nós Propomos! cidadania e inovação na educação geográfica" no estado de São Paulo, no Brasil, pode ser atingido.

Podemos compreender que o projeto “[...] comprova o protagonismo que os docentes têm na implementação e desenvolvimento do Projeto, mas também a necessidade de um maior compromisso institucional da escola" (CLAUDINO, 2014, p. 7). As práticas realizadas procuram, na medida de suas possibilidades e limites locais, romper com um Ensino Tradicional de Geografia.

As propostas dos professores participantes, no estado de São Paulo, buscaram a superação de práticas que ainda se apresentam sob os moldes do ensino tradicional, ao contribuir para sistematizar conhecimentos na educação básica. Em consonância com o estudo de Carvalho Sobrinho e Gengagel (2018), admitimos que o projeto causa uma ruptura com o ensino Tradicional de Geografia ao propor um olhar sensível para o aluno, para a Escola e para a comunidade local. 
Quadro 10 - Sistematização dos princípios do Projeto Nós Propomos! aplicados no estado de São Paulo

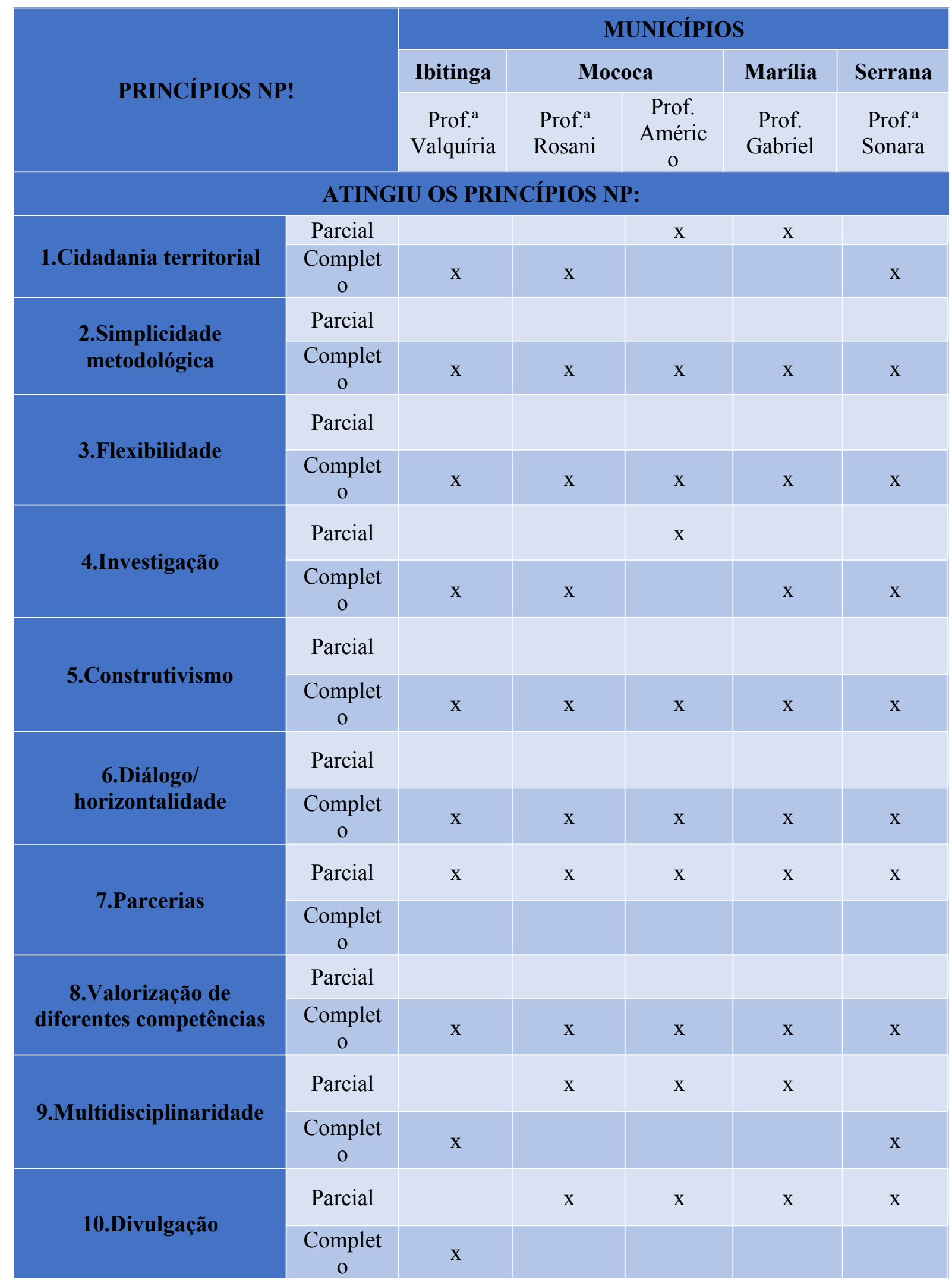

Fonte: elaborado pelo autor 
O quadro 10 expõe, de forma resumida, a sistematização dos princípios do projeto Nós Propomos! no estado de São Paulo. O referido quadro tem a função de explicitar quais princípios foram atingidos (completamente ou parcialmente)

Pelo exposto, é possível afirmarmos que as práticas se configuraram de formas plásticas/flexíveis e adaptadas às distintas realidades locais e agentes sociais que imperaram no desenvolvimento do projeto. Os professores desenvolveram ações previstas nos princípios do projeto (CLAUDINO, 2019a, 2019b) à sua maneira, formato e tempo de realização, moldando, assim, diferentes formas de promover aos alunos investigações críticas do local. Podemos notar evidências de práticas pedagógicas voltado ao social, para a consciência coletiva dos alunos (CAVALCANTI, 2019).

Assim, a promoção das práticas pedagógicas garantiu, ainda com seus limites e formatos distintos, a promoção de uma educação geográfica para a cidadania crítica, autônoma e propositiva por meio da participação social dos alunos e em uma Escola conectada aos problemas socioambientais globais e locais da comunidade. Desta forma, pudemos detectar que o projeto Nós Propomos! desenvolve-se sob a perspectiva de uma Educação articulada às questões sociais da complexa organização socioespacial do mundo e do local em um trabalho direto na comunidade. 


\section{CONSIDERAÇÕES FINAIS}

A Escola, no século XXI, ainda carrega práticas de Ensino Tradicionais de Geografia, no entanto, o mudo Globalizado nos impõe uma série de medidas e enfrentamentos dos problemas socioambientais para serem debatidos no espaço escolar. Neste sentido, é necessário buscar formas de trabalho pedagógico inovadoras, que mudem a perspectiva dos alunos quanto ao ato de aprender, de viver, de ler e mudar a realidade. Para isso, precisamos pensar que o ensino no século XXI envolve superação da perspectiva conteudista de disciplinas e da educação fragmentada e dissociada da realidade vivida.

Torna-se necessário reconhecer que a Escola e o ensino de Geografia precisam se reorganizar. É necessário redefinir seus projetos/papéis e suas ações, pois as práticas educativas demandam novas dimensões formativas, sobretudo numa perspectiva crítica/reflexiva e cidadã de ensino (LASTÓRIA et al., 2015a, 2015b).

Passemos a pensar em uma educação geográfica comprometida com os problemas socioambientais globais e, também, locais. Foco das vivências e dinâmicas sociais nas quais estamos envolvidos. A frase de ordem "pensar globalmente e agir localmente" parece caber nas demandas a serem assumidas pelas instituições governamentais e sociais, dentre elas a Escola. Neste contexto, surge o projeto "Nós Propomos! cidadania e inovação na educação geográfica".

Neste trabalho, procuramos levantar e caracterizar as práticas pedagógicas dos professores participantes no "Projeto Nós Propomos! cidadania e inovação na educação geográfica" no estado de São Paulo. Para atingir o referido objetivo central, coletamos dados e realizamos uma revisão bibliográfica especializada para nos permitir tecer considerações sobre as práticas focadas nesta investigação.

Descrevemos a sistemática do trabalho docente realizado, analisamos, sob a ótica dos participantes, os impactos das práticas desenvolvidas e refletimos sobre os desafios e os avanços do projeto, tendo em vista o ensino de Geografia e a formação cidadã no Brasil.

Notamos que as práticas dos professores participantes do projeto alinham-se aos princípios estabelecidos pelo projeto original mais amplo, bem como, às demandas pela promoção da cidadania, presentes em documentos nacionais e internacionais. Neste sentido, notamos que a plasticidade de realização do projeto faz os cinco professores terem sucesso em suas realizações. As experiências compartilhadas na comunidade escolar aconteceram de diversas maneiras, ou seja, moldando-se à complexa realidade das Escolas e turmas participantes com tempo e ritmos próprios. 
Pudemos perceber pelos relatos dos professores participantes fragmentos, explícitos e implícitos, de que o projeto promove a valorização de uma Escola em diálogo com a comunidade, por meio da participação dos alunos na investigação do meio, da problematização do local e da intervenção com proposição de soluções, apresentadas para a própria comunidade escolar e/ou para o poder público.

O projeto também obedece a uma mudança de paradigma educacional, para planejamento participativo e para governança. Coloca os professores e alunos como agentes que promovem debates e ações frente a uma cidadania territorial local (CLADINO, 2019a, 2019b). Para isso, desenvolve comportamentos e ações de responsabilidade social, que são esperados para a promoção do bem-estar coletivo da população.

As práticas pedagógicas desenvolvidas evidenciam um modo de ensinar e aprender, além de promover uma Educação cidadã que valoriza a perspectiva crítica, reflexiva e propositiva, por meio da construção de conhecimentos à emancipação intelectual dos sujeitos jovens, através de relações com o lugar (FREIRE, 2004).

Os alunos puderam vivenciar dificuldades reais e refletir sobre as mesmas, por meio das práticas pedagógicas realizadas. Para além disso, o projeto traz o local para o centro do ensino de Geografia em uma perspectiva de desenvolvimento de um sujeito ativo em seu meio. Cabe a este sujeito intervir, modificar e transformar seu espaço vivido para o bem-estar de todos.

Observamos avanços com relação a possibilidade de dialogismo, avanço da valorização dos estudos do local e a ressignificação do papel do professor na formação crítica e cidadã dos alunos.

Isto posto, esta investigação contribui para reforçar o caráter científico e pedagógico do trabalho de campo, presente no estudo do meio local, nas práticas pedagógicas de Geografia dos professores participantes do "Projeto Nós Propomos! cidadania e inovação na educação geográfica”, no estado de São Paulo, no Brasil. Além disso, a presente investigação, feita de forma colaborativa com a participação dos professores, será uma referência para estudos posteriores que focarão sobre este projeto de ensino de Geografia de caráter críticoreflexivo do cidadão ibero-americano.

Nesse sentido, ao analisarmos as práticas, percebemos que sim, é possível e viável fazer uma educação geográfica diretamente vinculada aos problemas socioambientais locais e à cidadania territorial. É possível romper com um Ensino de Geografia Tradicional e uma escola fechada e desconectada do cotidiano e da localidade dos alunos e professores. 
Alguns desafios, no entanto, devem ser vencidos para o futuro do projeto no estado de São Paulo, como: superação dos problemas que envolveram a logística para realizar o trabalho de campo com os alunos, estímulo à maior participação dos responsáveis na divulgação dos trabalhos dos alunos na Escola e no poder público, mediação de situações de vulnerabilidade social em que se encontra parte significativa dos alunos, desenvolvimento de formas mais efetivas de trabalho multidisciplinar dos professores das escolas.

Podemos apontar avanços com esta investigação, no sentido de sistematizar as práticas pedagógicas dos professores participantes e assim, permitir que os estudos sobre o mesmo sejam intensificados possibilitando montar, em estudos posteriores, uma configuração de todas as ações desenvolvidas no Brasil no âmbito do projeto.

Além disso, é preciso destacar que o projeto, no estado de São Paulo, está em construção nos municípios estudados nesta investigação e em fase de expansão. Exemplo dessa expansão são as práticas desenvolvidas em Rincão, a partir do ano de 2020. Salientamos, no entanto, que ainda não ocorreram significativas parcerias institucionais, como ocorre em Portugal e em alguns estados brasileiros, como em Tocantins e no Paraná. No estado de São Paulo, ainda não foi institucionalizado uma ampla e produtiva relação com o poder público local.

O projeto Nós Propomos! tem uma preocupação solidária e com a liberdade e a autonomia do indivíduo, que busca superar a ideia de separação entre Escola e Comunidade, presente em discursos e nas políticas públicas nacionais. A grande mensagem do projeto original sobre a Escola poder e dever ter preocupação com a comunidade e com a sociedade, por meio de uma educação geográfica voltada para a cidadania, também foi evidenciada nos projetos desenvolvidos no estado de São Paulo, além disso, admitimos uma consonância com o sentido da fala dos professores participantes, que o projeto caminha para uma Educação para a vida com atitudes coletivas e cidadãs.

Alinhado a esta intenção de ensino de Geografia, retomamos aqui a epígrafe do começo deste trabalho sobre o grande estudioso e intelectual Paulo Freire (1979), "o ser mais" tem um propósito muito específico de mostrar que existe uma opressão na sociedade, por meio da limitação das liberdades de nós podermos viver conforme a sua consciência. Neste sentido, "o ser mais" é aquilo que todos devem ser, o próprio direito de não viver uma vida minimizada, de obediência, uma vida no coletivo. Para o coletivo poder lutar para nunca "ser menos". Isto posto, o "ser mais" é aquele que tem a consciência de uma eterna vigilância sobre quando existe uma limitação das liberdades. Assim pode-se promover uma 
solidariedade de escala global e local de superar essas limitações, para que todos tenham condições de fazer um desenho de sua própria existência, para que todos possam "ser mais".

Esta investigação apresenta limitações no sentido de ter dado "voz" e "vez" apenas a cinco professores participantes. Além disso, não demos "voz" aos protagonistas do referido projeto, os alunos, por questões relacionadas ao tempo de realização do mestrado e das complexidades da pesquisa com menores de idade. Destacamos ser fundamental futuras pesquisas que abordem a visão, representações, aprendizagens, comportamentos e impactos nos/para os alunos participantes do projeto.

Isto posto, ficam alguns questionamentos para investigações futuras. Quais foram as contribuições que o projeto trouxe aos alunos? Quais mudanças foram possibilitadas a eles? Como foi a participação dos gestores e responsáveis na aprendizagem dos alunos participantes? A cidadania territorial está sendo praticada pelos alunos participantes egressos? Em que sentido? Quais as contribuições pessoais e acadêmicas que o projeto nos deixa? Como potencializar o trabalho de campo nas práticas pedagógicas do Projeto? Esta pesquisa contribuiu para inúmeras possibilidades de investigação serem desenvolvidas, pois envolve a educação para a cidadania.

Esta investigação buscou refletir para a potencialidade de um projeto de ensino científico que versa para a promoção do bem-estar e uma justiça social do e no coletivo. Neste sentido, admitimos o projeto Nós Propomos! e a Ciência como investimento em qualidade de vida e em desenvolvimento social igualitário e digno para as populações para um bem comum. Ciência e Educação, juntas, trazem progresso material e humano para as sociedades, promovem o pensamento crítico e asseguram paz, trabalho, renda, saúde e a aplicação dos Direitos Humanos na esfera local e global.

Assim, pesquisar e aplicar uma educação cidadã torna-se urgente em um mundo que assiste a uma crise global de pandemia da COVID-19, em que os povos devem assumir responsabilidades de cidadania territorial ativa em busca por uma solidariedade global e local reflexiva, crítica, dialógica e propositiva. 


\section{REFERÊNCIAS}

ALENTEJANO, P. R. R.; ROCHA LEÃO, O. M. Trabalho de campo: uma ferramenta essencial para os geógrafos ou um instrumento banalizado? Boletim Paulista de Geografia, São Paulo, n. 84, p. 51-67, 2006. Disponível em: http://www.uel.br/cce/geo/didatico/ omar/pesquisa_geografia_fisica/BPG84_Pesquisa.pdf. Acesso em: 20 ago. 2018.

ALVES, J. C. M. A participação social a partir do Programa Federal Territórios da cidadania: o caso do território do Cariri/CE. 2013. Dissertação (Mestrado Desenvolvimento Regional Sustentável) - Universidade Federal do Ceará, Juazeiro do Norte-CE, 2013.

ALVES-MAZZOTTI, A. J. Impacto da pesquisa educacional sobre as práticas escolares. In: ZAGO, N.; CARVALHO, M. P.; VILELA, R. A. T. (Org.). Itinerários de pesquisa: perspectivas qualitativas em sociologia da educação. Rio de Janeiro: DP\&A, 2003. p. 33-48.

ANDRÉ, M. Etnografia da prática escolar. São Paulo: Papirus, 2005.

ARAYA PALACIOS, F.; ÁLVAREZ BARAHONA, S. Desarollo del pensamiento Geográfico y formacíon ciudadana: una mirada del espacio vivido. Signos Geográficos, Goiânia-GO, v. 1, p. 1-18, 2019. Disponível em:

https://www.revistas.ufg.br/signos/article/view/59376. Acesso em: 12 dez. 2019.

ASSOCIAÇÃO NACIONAL DE PÓS-GRADUAÇÃO E PESQUISA EM CIÊNCIAS SOCIAIS - ANPOCS. Moção no 001 - 28/10/2011 - "Ética em pesquisa". Caxambu/MG: ANPOCS, 2011. Disponível em: https://anpocs.com/index.php/universo/mocoes-sp1243763237/755-mocao-etica-em-pesquisa-28102011. Acesso em: 10 out. 2019.

ASSOCIAÇÃO PORTUGUESA DE EDUCAÇÃO AMBIENTAL - ASPEA. Projeto "Nós Propomos!" uma escola comprometida com a comunidade. ASPEA, 2020. Disponível em: https://aspea.org/index.php/pt/noticias/523-projeto-nos-propomos-uma-escola-comprometidacom-a-comunidade. Acesso: 26 mar. 2020.

AZANHA, J. M. P. Uma ideia de pesquisa educacional. São Paulo: EDUSP, 1992.

AZEVEDO, T. A. C.; LASTÓRIA, A. C.; FERNANDES, S. A. S. Práticas educativas e a formação cidadã no Brasil. In: CLAUDINO, S.; SOUTO GONZÁLEZ, M. X.; DOMENECH, M. A.; BAZOLLI, J.; LENILDE, R.; GENGNAGEL, C. L.; MENDES, A.; SILVA, B. A. T. (Org.). Geografia, Educação e Cidadania. Lisboa: ZOE/Centro de Estudos Geográficos, Instituto de Geografia e Ordenamento do Território IGOT, 2019.p. 486-500.

BARDIN, L. Análise de conteúdo. São Paulo: Edições 70, 2016.

BAZOLLI, J. A. "Projeto Nós Propomos" multiplicidade de atores e diversidade na Educação Cidadã. Revista Conexão UEPG. Ponta Grossa, v. 13, n. 1, p. 94-109, jan./abr. 2017. Disponível em: https://www.revistas2.uepg.br/index.php/conexao/article/view/9335. Acesso em: 05 jul. 2019.

BAZOLLI, J. A.; CLAUDINO, S. N.; COSTA E SILVA, M. V.; VIANA, S. F. R.; SILVA, W. C. (Org.). A extensão Universitária como indutora à Cidadania: a experiência do "Nós 
Propomos". Palmas-TO: Ed: Eduft, 2017. Disponível em: http://online.fliphtml5.com/ wskm/ltan/. Acesso em 10 set. 2018.

BAZOLLI, J. A.; COSTA E SILVA, M. V.; VIANA, S. F. R. Manual Nós Propomos!, Palmas-TO: Ed: Eduft, 2017. Disponível em: http://online.fliphtml5.com/wskm/cbhi/\#p=1. Acesso em: 20 de fev. de 2019.

BAZOLLI, J. A.; DANTAS, R. L.; COELHO, C. E. Inovação e Democracia: civic hacking como ferramenta de tecnologia social na experiência do "Projeto Nós Propomos! cidadania e inovação na educação geográfica" - Palmas/TO. Revista Observatório, Palmas, v. 4, n. 6, p. 944-964, out./dez. 2018. Disponível em:

https://sistemas.uft.edu.br/periodicos/index.php/observatorio/article/view/5644. Acesso em: 24 de set. 2019.

BOGDAN, C. R.; BIKLEN, K. S. Investigação Qualitativa em Educação: uma introdução à teoria e os métodos, Porto, Portugal, 1994.

BOSCOLO, D. Projetos de estudos do meio em escolas públicas em Santana de Parnaíba-SP. 2007. 166 f. Dissertação (Mestrado em Geografia Humana) - Faculdade de Filosofia, Letras e Ciências Humanas, Universidade de São Paulo, São Paulo, 2007.

BRASIL. Base nacional comum curricular. Brasília/DF: Ministério da Educação; Secretaria da Educação Básica, 2017.

BRASIL. Casa Civil. Subchefia para Assuntos Jurídicos. Lei n. 10.257, de 10 de julho de 2001. Regulamenta os arts. 182 e 183 da Constituição Federal, estabelece diretrizes gerais da política urbana e dá outras providências. Brasília/DF, 2001.

BRASIL. Constituição da República Federativa do Brasil. Brasília: Senado Federal, 1988.

BRASIL. Lei n. 9.394, de 20 de dezembro de 1996. Estabelece as diretrizes e bases da educação nacional. Brasília/DF, 1996.

BRASIL. Ministério da Educação Secretaria de Educação Fundamental. PCN: História, Geografia. Brasília: MEC/SEF, 1998.

BRASIL. Ministério da Educação. Secretaria de Educação Fundamental. Parâmetros curriculares nacionais: apresentação dos temas transversais, ética. Brasília/DF, 1997.

BRITO, A. X.; LEONARDOS, A. C. A identidade das pesquisas qualitativas: construção de um quadro analítico. Cadernos de Pesquisa, n. 113, 2001.

BROOKS, C.; QIAN, G.; SALINAS-SILVA, V. O que está por vir na educação Geográfica? Uma perspectiva da União Geográfica Internacional. Giramundo, Rio de Janeiro, v. 4, n. 7 , p. 7-19, 2017. Disponível em:

https://www.cp2.g12.br/ojs/index.php/GIRAMUNDO/article/view/2173/1456. Acesso em: 05 nov. 2019.

CALLAI, H, C. O estudo do lugar como possibilidade da construção da identidade e do pertencimento. A Questão Social no Novo Milênio. In: VIII Congresso Luso-Afro-Brasileiro de Ciências Sociais. Coimbra/POR, 2004. Disponível em:

https://www.ces.uc.pt/lab2004/pdfs/HelenaCallai.pdf. Acesso em: 10 abr. 2020. 
CALLAI, H. C. A. Geografia ensinada: os desafios de uma educação geográfica. In: MORAIS, E. M. B.; MORAIS, L. B. (Org.). Formação de Professores: conteúdos e metodologias no ensino de Geografia. Goiânia: NEPEG, 2010. p. 15-38. Disponível em: http://nepeg.com/newnepeg/wp-content/uploads/2014/04/LIVRO-FORMA $\% \mathrm{C} 3 \% 87 \% \mathrm{C} 3 \% 83 \mathrm{O}-\mathrm{DE}-\mathrm{PROFESSORES}-\mathrm{CONTE} \% \mathrm{C} 3 \% 9 \mathrm{ADOS}-\mathrm{E}-\mathrm{METODOLOGIAS}-$ NO-ENSINO-DE-GEOGRAFIA-2010.pdf. Acesso em: 08 out. 2019.

CALLAI, H. C. Educação Geográfica: reflexões e prática. 2. ed. Ijui: Editora UNIJUI, 2011.

CAMPOS, R. R. Breve histórico do pensamento geográfico brasileiro nos séculos XIX e XX. Jundiaí: Paco Editorial, 2011.

CARLOS, A. F. A. O lugar no/do mundo. São Paulo: Hucitec, 1996.

CARLOS, A. F. A.; ALVES, G.; PADUA, R. F. Justiça Espacial e o direito à cidade. São Paulo: Editora Contexto, 2017.

CARVALHO FILHO, O. R.; AZEVEDO, T. A. C.; ALMEIDA, J. F.; LASTÓRIA, A. C.; FERNANDES, S; A. S. O grupo de Estudo da Localidade, o GEOFORO e as ações vinculadas ao Projeto Nós Propomos! In: PIZZINATO, L. A. R.; PALACIOS MENA, N..; SOUTO GONZÁLEZ, X. M. (Ed.) La construcción global de una enseñanza de los problemas sociales desde el Geoforo Iberoamericano. Barcelona: Geocrítica, Textos Electrónicos, 2019. p. 291-301. Disponível em:

http://www.ub.edu/geocrit/geoforo_iberoamericano_2019.pdf. Acesso em: 08 out. 2019.

CARVALHO FILHO, O. R.; MENEGHESSO, V. A.; CARNIEL, F. S. O direito ao lazer e o projeto Nós Propomos! Ações educativas em Geografia envolvendo a cidadania. In:

FERREIRA, E. B.; LOPES, M. M. (Org.). Pesquisas em educação: cidadania, ensino e sociedade. São Carlos: Pedro \& João, 2020.

CARVALHO SOBRINHO, H. A cidade e o ensino de Geografia: significação a partir das atividades do Projeto Nós Propomos. In: SOUZA, V. L. C. A.; LEITE, C. M. C. (Org.). Ensinar e aprender Geografia por meio do Projeto Nós Propomos. Goiânia: C \& A Alfa Comunicação, 2018. p. 49-65.

CARVALHO SOBRINHO, H.; GENGAGEL, C. L. Práticas pedagógicas em Geografia para uma educação cidadã emancipadora. Revista Interdisciplinar de Direitos Humanos Bauru (RIDH), v. 6, n. 2, p. 87-100, jul./dez., 2018. Disponível em:

https://www3.faac.unesp.br/ridh/index.php/ridh/article/view/622. Acesso em: 05 fev. 2019.

CASTELLAR, S. M. V. Educação Geográfica: a psicogenética e o conhecimento escolar.

Cad. Cedes, Campinas, v. 25, n. 66, p. 209-225, maio/ago. 2005. Disponível em: http://www.scielo.br/pdf/ccedes/v25n66/a05v2566.pdf. Acesso em: 20 out. 2018.

CAVALCANTI, L, S. Pensar pela Geografia: ensino e relevância social. Goiânia: C\&C Alfa Comunicações, 2019.

CAVALCANTI, L. S. A Geografia escolar e a Cidade: ensaios sobre o ensino de Geografia para a vida urbana cotidiana. São Paulo: Papirus, 2010.

CAVALCANTI, L. S. Geografia e prática de ensino. Goiânia: Alternativa, 2002. 
CAVALCANTI, L. S. Geografia, escola e construção de conhecimentos. 10. ed. São Paulo: Editora Papirus, 2007.

CAVALCANTI, L. S. O ensino de Geografia na escola. Campinas, São Paulo: Papirus, 2012.

CAVALCANTI, L. S.; SOUZA, C. V. A formação do professor de Geografia para atuar na Educação Cidadã. Scripta Nova: Revista Electrónica de Geografía y Ciencias Sociales, v. 18, n. 494, p. 1-17, dez. 2014. Disponível em:

https://revistes.ub.edu/index.php/ScriptaNova/article/view/14970. Acesso em: 10 nov. 2018.

CLAUDINO, S. A educação geográfica em Portugal e os desafios educativos. Giramundo, Rio de Janeiro, v. 2, n. 3. 2015, p. 7-19. Disponível em:

https://www.cp2.g12.br/ojs/index.php/GIRAMUNDO/article/view/204. Acesso em: 23 set. 2018.

CLAUDINO, S. Construir uma escola cidadão por meio do Projeto Nós Propomos! um desafio no espaço ibero-americano. Revista Sobre Tudo, v. 10, n. 2, p. 33-52, 2019a.

Disponível em: http://ojs.sites.ufsc.br/index.php/sobretudo/article/view/3881. Acesso em: 22 abr. 2020.

CLAUDINO, S. Educação Geográfica, Trabalho de Campo e Cidadania. O Projeto Nós Propomos! In: Veiga, F. H. O Ensino na Escola de Hoje - Teoría, Investigação e Prática. Lisboa: Climepsi Editores, 2018a. p. 265-303.

CLAUDINO, S. Educação, riscos e currículos escolares. Territorium, Coimbra, v. 25, n. 2, p. 5-18, 2018b. Disponível em: https://digitalis

dsp.uc.pt/bitstream/10316.2/44187/1/Educacao\%2C_risco_e_curriculos_escolares.pdf. Acesso em: 10 dez. 2019.

CLAUDINO, S. Escola, Educação geográfica e cidadania territorial. Scripta Nova: Revista Electrónica de Geografía y Ciencias Sociales, v. 9, n. 494, 2014. Disponível em: https://revistes.ub.edu/index.php/ScriptaNova/article/view/14971. Acesso em: 06 ago. 2018.

CLAUDINO, S. O ensino da Geografia em Portugal: uma perspectiva. Inforgeo, n. 15, p. 183-204, 2000. Disponível em: http://www.apgeo.pt/sites/default/files/inforgeo_15.pdf. Acesso em: 07 fev. 2019.

CLAUDINO, S. Project We Propose! building territorial citizenship from school. In: PINEDA-AFONSO, J. A.; ALBA-FERNANDEZ, N.; NAVARRO-MEDINA, E. Handbook of Research on Education for Participative Citizenship and Global Prosperity. Hershey: IGI Global, 2019b. p. 350-382.

CLAUDINO, S.; FERNANDES, S. A. S.; GRAZZINI, G. G. Projeto Nós Propomos! cidadania e formação de professores: o caso da Escola de Oracina/Marília. In: HORTAS, M. J.; DIAS, A.; ALBA, N. (Ed.). Ensenãr y Aprender Didácticas de las Ciencias Sociales: la formación del professorado desde una perspectiva sociocrítica. Lisboa: Los Autores, 2019. p. 467-475. Disponível em: http://didactica-ciencias-sociales.org/wp-content/uploads/ 2019/10/XXX-publicacion-simposio-lisboa-final_compressed-min.pdf. Acesso em: 06 jan. 2020 . 
CLAUDINO, S.; SOUTO GONZÁLEZ, M. X.; ARAYA PALACIOS, A. F. Los Problemas Socio-Ambientales em Geografía: una Lectura Iberoamericana. Revista Lusófona de Educação, n. 39, p. 55-73, 2018. Disponível em: https://revistas.ulusofona.pt/index.php/rleducacao/article/view/6384/3891. Acesso em: 06 de mar. 2019.

CLAUDINO, S.; SOUTO GONZÁLEZ, M. X.; DOMENECH, M. A.; BAZOLLI, J.; LENILDE, R.; GENGNAGEL, C. L.; MENDES, A.; SILVA, B. A. T. (Org.). Geografia, Educação e Cidadania. Lisboa: ZOE/Centro de Estudos Geográficos, Instituto de Geografia e Ordenamento do Território IGOT, 2019. Disponível em:

http://nospropomos2016.weebly.com/livro.html. Acesso em: 10 jun. 2019.

CLEMENTE, F. A importância do "Projeto Nós Propomos! cidadania e inovação na educação geográfica" para a cidadania participativa. In: CLAUDINO, S.; SOUTO GONZÁLEZ, M. X.; DOMENECH, M. A.; BAZOLLI, J.; LENILDE, R.; GENGNAGEL, C. L.; MENDES, A.; SILVA, B. A. T. (Org.). Geografia, Educação e Cidadania. Lisboa: ZOE/Centro de Estudos Geográficos, Instituto de Geografia e Ordenamento do Território IGOT, 2019. p. 86-93.

COMISSÃO DAS COMUNIDADES EUROPEIAS. Governança europeia: um livro branco. Bruxelas: Comissão das Comunidades Europeias, 2001. Disponível em: http://www.laicidade.org/wp-content/uploads/2006/09/ue-governanca-2001.pdf. Acesso em: 29 out. 2019.

COMMISSION OF GEOGRAPHICAL EDUCATION. Carta internacional de educação geográfica. Washigton: International Geographical Union, Commission Geographical Education, 1992. Disponível em: http://www.igu-cge.org/wp-content/uploads/2018/02/15.Portuguese.pdf. Acesso em: 13 jul. 2019.

COMMISSION OF GEOGRAPHICAL EDUCATION. Carta internacional de educação geográfica. Pekin, 2016. Disponível em:

http://www.igu-cge.org/wp-content/uploads/2019/08/IGU_2016_spanish_updated.pdf. Acesso em: 28 fev. 2020.

CORDEIRO, J. M. P.; OLIVEIRA, A. G. A aula de campo em geografia e suas contribuições para o processo de ensino-aprendizagem na escola. Geografia, Londrina, v. 20, n. 2, p. 99114, maio/ago. 2011. Disponível em:

http://www.uel.br/revistas/uel/index.php/geografia/article/view/7416. Acesso em: 08 out. 2018.

COSTA, A. C. G. Protagonismo juvenil: adolescência, educação e participação democrática. Salvador: Fundação Odebrecht, 2000.

DEON, A. R.; CALLAI, H. C. A Educação Escolar e a Geografia como Possibilidades de Formação para a Cidadania. Contexto \& Educação, ano 33, n. 104, p. 264-290, jan./abr. 2018. Disponível em: https://www.revistas.unijui.edu.br/index.php/contextoeducacao/ article/view/6741/5662.. Acesso em: 06 mar. 2019.

DEPRESBITERIS, L. O desafio da avaliação da aprendizagem: dos fundamentos a uma proposta inovadora. São Paulo: EPU, 1989.

DEWEY, J. Experiência e educação. Tradução Anísio Teixeira. 2. ed. São Paulo: Companhia Editora Nacional, 1976. 
DOMENECH, A. M. R.; FERNANDES, S. A. S.; CLAUDINO, S. NÓS PROPOMOS!! A possibilidade da participação cidadã desde a escola. 2018. Disponível em: https://drive.google.com/file/d/1yG9L9WXjfKwMQXbF9P7L93dgjIAMxvFY/view. Acesso em: 05 mar. de 2020.

DUARTE, R. Pesquisa qualitativa: reflexões sobre o trabalho de campo. Cadernos de Pesquisa, n. 115, mar. 2002. Disponível em: http://www.scielo.br/scielo.php?pid=S010015742002000100005\&script=sci_abstract\&tlng=pt. Acesso: 08 ago. 2018.

FERNANDES, S. A. S.; LASTÓRIA, A. C. Redescobrindo o trabalho de campo para aprender e ensinar o lugar. In: LASTÓRIA, A. C.; ROSA, A. V. (Org.). Elos da cidadania: localidade, escola e ação. São Carlos/SP: Compacta, 2014, p. 145-158.

FERNANDES, S. A. S.; LASTÓRIA, A. C.; CLAUDINO, S. Currículo e didática da geografia dialogam com a formação para a cidadania? Possibilidades formativas desenvolvidas em projetos pesquisa e extensão universitária. In: COLÓQUIO INTERNACIONAL DA REDE LATINO-AMERICANA DE INVESTIGADORES DE DIDÁTICA DE GEOGRAFIA, 5., 2018. Anais... Goiânia: LEPEG/IESA/UFG, 2018. p. 150159. Disponível em: http://geopaideia.org/wp content/uploads/2019/02/ANAIS_Redladgeo_2018.pdf. Acesso em: 08 mar. 2019.

FERNANDES, S. S. A.; MONTEAGUDO GARCIA, D.; SOUTO GONZÁLEZ, X. M. Educación Geográfica y las salidas de campo como estrategia didáctica: un estudio comparativo desde el Geoforo Iberoamericano Biblio3W - Revista Bibliográfica de Geografía y Ciencias Sociales, Barcelona, v. XXI, n. 1.155, 2016. Disponível em: http://www.ub.edu/geocrit/b3w-1155.pdf. Acesso em: 09 nov. 2018.

FERRÃO, João. O Ordenamento do Território como Política Pública. Lisboa: Fundação Calouste Gulbenkian, 2014.

FITA ESTEVE, S. F.; CLAUDINO, S.; SOUTO GONZÁLVEZ, X. M. La globalización del Geoforo Iberoamericano en 2018. Biblio3W - Revista Bibliográfica de Geografía y

Ciencias Sociales, n. XXIII, 2018. Disponível em: http://www.ub.edu/geocrit/b3w-1258.pdf. Acesso em: 09 jun. 2019.

FORUM IBERO-AMERICANO SOBRE EDUCAÇÃO, GEOGRAFIA E SOCIEDADE GEOFORO. Foro Iberoamericano Sobre Educación, Geografía y Sociedad. 2008. Disponível em: http://geoforo.blogspot.com/. Acesso em: 28 fev. 2020.

FRANCISCHETT, M. N. Nós Propomos! Ensino de Geografia com significado na pesquisa na Unioeste/FB/Paraná. Francisco Beltrão: Unioeste. 2017.

FREIRE, P. A Educação na Cidade. São Paulo: Cortez, 2001.

FREIRE, P. Educação e mudança. 15 ed. Rio de Janeiro: Paz e terra, 1979.

FREIRE, P. Paulo. Pedagogia do Oprimido. 42. ed. Rio de Janeiro: Paz e Terra, 2004.

FREIRE, P. Pedagogia da autonomia. 15. ed. Rio de Janeiro: Paz e Terra, 2014.

FREIRE, Paulo. Educação como Prática da Liberdade. 19. ed. Rio de Janeiro: Paz e Terra, 1989. 
GARCÍA PÉREZ, F. F.; MORENO FERNÁNDEZ, O.; RODRÍGUEZ MARÍN, F. Problemas del mundo y educación: hacia una ciudadanía planetária. In: BORGHI, B.; GARCÍA PÉREZ,, F. F.; MORENO FERNÁNDEZ, O. (Org.). Noví Cíves: cittadini dall ínfanzia ín poí. Bologna: Pàtron Editore, 2015. p. 33-41.

GENGNAGEL, C. L. Projeto Nós Propomos! integrado com a comunidade: a construção de uma educação geográfica áutada no protagonismo juvenil. In: GENGNAGEL, C. L.; RUBERT, N. M. A. (Org.). Centro de Ensino Integrado UPF - 30 anos: diferentes olhares, novas práticas, Editora Livrologia, Chapecó/SC, 2019. p. 79-92.

GIL, A. C. Métodos e técnicas de pesquisa social. 5. ed. São Paulo: Atlas, 1999.

GUIDO, C.; ANDREIS, A. M. Nós Propomos! em Chapecó: o lugar em pesquisa em diálogo com a Escola. In: ENCONTRO NACIONAL DE PRÁTICA DE ENSINO DE GEOGRAFIA: POLÍTICAS, LINGUAGENS E TRAJETÓRIAS. 14., 2019. Anais... Campinas: Unicamp, 2019. p. 285-297. Disponível em:

https://ocs.ige.unicamp.br/ojs/anais14enpeg/article/view/2886. Acesso em: 09 out. 2019.

HALASZEN, L. Tecnologias geocolaborativas no ensino de Geografia: proposta didática para o Ensino Médio. 2020. 147 f. Dissertação (Mestrado em Geografia) - Universidade Estadual do Centro Oeste (UNICENTRO), Guarapuava, 2020.

HELlER, A. O Cotidiano e a História. Tradução de Carlos Nelson Coutinho e Leandro Konder 4. ed. São Paulo: Paz e Terra, 1999.

HRCHOROVITCH, G, D, G. Nós Propomos! perspectivas metodológicas para o ensino de Geografia nos anos finais do Ensino Fundamental. 2019. 185 f. Dissertação (Mestrado em Geografia) - Universidade Estadual do Oeste do Paraná, Francisco Beltrão, 2019.

INSTITUTO DE GEOGRAFIA E ORDENAMENTO DO TERRITÓRIO - IGOT. Projeto Nós Propomos! Cidadania e Inovação na Educação Geográfica 2018/19. Lisboa, 2019. Disponível em: http://nospropomos2016.weebly.com/uploads/6/4/5/1/64517865/regulamentoprojeto-n\%C3\%B3s-propomos-2018_19.pdf. Acesso em: 10 mar. 2020.

INTERNACIONAL YEAR OF GLOBAL UNDERSTANDING - IYGU. News. Disponível em: http://www.global-understanding.info/pt. Acesso em: 18 jul. 2019.

LACOSTE, Y. A pesquisa e o trabalho de campo: um problema político para os pesquisadores, estudantes e cidadãos. Boletim Paulista de Geografia, São Paulo, n. 84, p. 77-92, 2006. Disponível em:

http://www.uel.br/cce/geo/didatico/omar/pesquisa_geografia_fisica/BPG84_Pesquisa.pdf. Acesso em: 20 ago. 2018.

LACOSTE, Yves. A geografia - isso serve, em primeiro lugar para fazer guerra. Tradução de Maria Cecília França. Campinas/SP: Papirus, 1988.

LAKATOS, E. M.; MARCONI, M. A. Fundamentos de metodologia científica. São Paulo: Atlas, 2010.

LASTÓRIA, A. C.; CALLAI, H.; CAVALCANTI, L. S.; SOUZA, V. C. Cittadinanza ed educazione per la cittadinanza nel contesto brasiliano. In: BORGHI, B.; GARCÍA PÉREZ, F. 
F.; MORENO FERNÁNDEZ, O. (Org.). Noví Cíves: cittadini dall ínfanzia ín poí. Bologna: Pàtron Editore, 2015b. p. 191-200.

LASTÓRIA, A. C.; CALLAI, H.; CAVALCANTI, L. S.; SOUZA, V. C. School education in Brazil and the goal of citizen formation: indicators in official proposals and in formative pratices. In: BORGHI, B.; GARCÍA PÉREZ, F. F.; MORENO FERNÁNDEZ, O. (Org.). Nóvi cíves: cittadini dallinfanzia in poi. Bologna: Pàtron Editore, 2015a. v. 1, p. 43-52.

LASTÓRIA, A. C.; MELLO, R. C. Cotidiano e lugar: categorias teóricas da história e da geografia escolar. Universitas, Fernandópolis, v. 4, p. 27-34, 2008. Disponível em: https://pt.scribd.com/document/57401581/COTIDIANO-E-LUGAR-CATEGORIASTEORICAS-DA-HISTORIA-E-DA-GEOGRAFIA-ESCOLAR. Acesso em: 17 ago. 2018.

LASTÓRIA, A. C.; ROSA, A. V.; ASSOLINI, F. E. P. (Org.). Almanaque de espaços não formais de ensino da Região Metropolitana de Ribeirão Preto-SP. Ribeirão Preto-SP, 2019. Disponível em: https://drive.google.com/file/d/1QSJLGkAr2rfZmL8Gfey5ORiy7NaZNmY/view. Acesso em 06 dez. 2019.

LASTÓRIA, A. C.; SANTOS, J. F.; MELLO, R. C. Considerações sobre os retrocessos nas políticas educacionais brasileiras durante o Governo do presidente Michel Temer. Revista Pedagógica, Chapecó, v. 20, n. 43, p. 18-41, jan./abr. 2018. Disponível em: https://bell.unochapeco.edu.br/revistas/index.php/pedagogica/article/view/3934.Acesso em: 20 jul. 2018.

LAVRATTI, I, M. Práticas ambientais como possibilidades de Educação Emancipatória: interfaces entre o "Projeto Nós Propomos! cidadania e inovação na educação geográfíca" e o 'Observatório do Meio Ambiente'. 2018. 74 f. Monografia (Trabalho de conclusão de curso em Ciências Sociais) - Faculdade de Filosofia e Ciências, Universidade Estadual Paulista (UNESP), Marília, 2018.

LAVRATTI, I. M.; FERNANDES, S. A. S. Cidadania territorial na educação básica: o Projeto Nós Propomos e o Observatório do Meio Ambiente em Marília-SP. Revista Querubim - Revista Eletrônica de Trabalhos Científicos nas áreas de Letras, Ciências Humanas e Ciências Sociais, ano 15, n. 38 p. 85-92, 2019. Disponível em: https://www.academia.edu/41976010/Cidadania_territorial_na_educa $\% \mathrm{C} 3 \% \mathrm{~A} 7 \% \mathrm{C} 3 \% \mathrm{~A} 3 \mathrm{o} \_\mathrm{b}$ \%C3\%A1sica_o_Projeto_N\%C3\%B3s_Propomos_e_o_Observat \%C3\%B3rio_do_Meio_Āmbiente_em_Mar\%C3\%AD̄i-_-SP. Acesso em: 20 set. 2019.

LEÃO, P. N. Participação popular não institucional: Projeto Nós Propomos! enquanto ferramenta de estímulo à democracia participativa. 2018. $74 \mathrm{f}$. Monografia (Trabalho de conclusão de curso de Direito) - Universidade Federal do Tocantins, Palmas, 2018.

LOIZAGA, V, B. Las "Sociales soñadas": innovación educativa y participación ciudadana en Geografía e Historia a partir de algunas experiencias valencianas. 2019. 81 f. Monografia (Trabalho de Conclusão de Curso em Educação Secundária - Geografia e História) Universitat de València, Valência, 2019.

LOPES, C. S.; PONTUSCHKA, N. N. Estudo do meio: fundamentos e estratégias. Fundamentum, Maringá, n. 56, 2010.

LOPES, C. S.; PONTUSCHKA, N. N. Estudo do meio: teoria e prática. Geografia, Londrina, v. 18, n. 2, p. 173-191, 2009. Disponível em: 
http://www.uel.br/revistas/uel/index.php/geografia/article/view/2360. Acesso em: 20 ago. 2018.

LOURENÇO FILHO, L. A.; MENDONÇA, S. A autonomia do educando na pedagogia de Dewey. EccoS, São Paulo, n. 33, p. 187-203, jan./abr. 2014. Disponível em: https://periodicos.uninove.br/index.php?journal=eccos\&page $=$ article\&op $=$ view\&path $\% 5 B$ $\% 5 \mathrm{D}=4275$. Acesso em: 19 out. 2019.

LÜDKE, M.; ANDRÉ, M. Pesquisa em Educação: abordagens qualitativas. São Paulo: EPU, 1986.

LUZ NETO, D. R. S. Projeto Nós Propomos! no ensino de Geografia: alternativas de interpretação territorial no ensino de Geografia por meio de novas tecnologias. Revista Educação Geográfica em Foco, v. 5, p. 1, 2019. Disponível em: http://periodicos.puc-rio.br/index.php/revistaeducacaogeograficaemfoco/article/view/1010. Acesso em: 10 jan. 2020.

MARÇAL, M. P. V. As representações sociais sobre o conceito e a Importância do Ensino de Geografia. Cadernos da Pedagogia, São Carlos, ano 6, v. 6, n. 11, p. 34-46, jul./dez. 2012. Disponível em: http://www.cadernosdapedagogia.ufscar.br/index.php/cp/article/viewFile/ 432/187. Acesso em: 09 jan. 2019.

MARCONI, M. A.; LAKATOS, E. M. Técnicas de pesquisa. 3. ed. São Paulo: Atlas, 1999.

MARTINS, H. H. T. S. Metodologia qualitativa de pesquisa. Educação e Pesquisa, São Paulo, v. 30, n. 2, p. 289-300, 2004. Disponível em:

http://www.scielo.br/pdf/ep/v30n2/v30n2a07.pdf. Acesso em: 10 mar. 2019.

MATOS, J, F. Educar para a cidadania hoje? In: CARVALHO, C.; SOUSA, F.; PINTASSILGO, J. (Org.) A educação para a cidadania como dimensão transversal do currículo escolar. Porto: Porto Editora. 2005. p. 37-47.

MENDONÇA, S.; CLAUDINO, S. N. "Projeto Nós Propomos! cidadania e inovação na educação geográfica": Uma rede crescente de cidadania territorial. In: ENCONTRO NACIONAL DE GEOGRÁFOS: A CONSTRUÇÃO DO BRASIL: GEOGRAFIA, AÇÃO POLÍTICA E DEMOCRACIA. 18., 2016. Anais... São Luiz/MA, 2016. p. 1-9.

MENEGHESSO, V.; CARVALHO FILHO, O. R.; LASTÓRIA, A. C. O projeto Nós Propomos! e os espaços públicos de lazer: práticas de ensino de Geografia envolvendo a formação cidadã. In: ENCONTRO NACIONAL DE PRÁTICA DE ENSINO DE GEOGRAFIA: POLÍTICAS, LINGUAGENS E TRAJETÓRIAS. 14., 2019. Anais... Campinas: Unicamp, 2019. p. 2963-2974. Disponível em:

https://ocs.ige.unicamp.br/ojs/anais14enpeg/article/view/3127. Acesso em: 10 mar. 2020.

MONTORO, A. F. Construir uma sociedade mais justa. In: CHALITA, G. (Org.). Vida para sempre jovem. São Paulo: Siciliano, 1992. p. 18-30.

MORENO LACHE, N.; CELY RODRÍGUEZ, A. C. (Org.). Concepciones e imágenes de Cuidad. Bogotá: Universidad Pedagógica Nacional, CIUP, 2015. 
MURARO, D. N. Relações entre a Filosofia e a Educação de John Dewey e de Paulo Freire. Educação \& Realidade, Porto Alegre, v. 38, n. 3, p. 813-829, jul./set. 2013. Disponível em: http://www.scielo.br/pdf/edreal/v38n3/07.pdf. Acesso em: 10 fev. 2020.

NEVES, N. J. Pesquisa qualitativa - características, usos e possibilidades. Caderno de pesquisa em Administração, São Paulo, v. 1, n. 3, $2^{\circ}$ sem. 1996. Disponível em: http://www.hugoribeiro.com.br/biblioteca-digital/NEVES-Pesquisa_Qualitativa.pdf. Acesso em: 19 out. 2019.

NIDELCOFF, M, T. A escola e a compreensão da realidade. São Paulo: Brasiliense, 1979. OLIVEIRA, C. D. M.; ASSIS, R. J. S. Travessias da aula em campo na geografia escolar: a necessidade convertida para além da fábula. Educação e Pesquisa, São Paulo, v. 35, n.1, p. 195-209, jan./abr. 2009. Disponível em: https://www.scielo.br/pdf/ep/v35n1/a13v35n1.pdf. Acesso em: 20 de fev. 2010.

OLIVEIRA, M. P. Um conceito de cidadania para se trabalhar a cidade. Geographia, Niterói, v. I, n. 1, p. 93-120, 1999. Disponível em:

https://periodicos.uff.br/geographia/article/download/13365/8565. Acesso em: 20 nov. 2018.

OLIVEIRA, R. C. O trabalho do antropólogo: olhar, ouvir, escrever. Revista de

Antropologia, São Paulo, USP, v. 39, n. 1, p. 13-37, 1996. Disponível em:

http://www.revistas.usp.br/ra/article/view/111579. Acesso em: 05 abr. 2019.

PAIXÃO, K. C. Ensino de Geografia e as relações raciais: o projeto Nós Propomos! como intervenção metodológica para o resgate da cultura e identidade na comunidade remanescente quilombola de Vila Nova Jutaí - Breu Branco/PA. 2019. 84 f. Monografia (Trabalho de Conclusão de Curso em Geografia) - Faculdade de Geografia, Universidade Federal do Sul e Sudeste do Pará (UNIFESSPA), Marabá, 2019.

PALACIOS MENA, N. P.; FERNANDES, S. A. A. El entorno cercano, salidas de campo y la enseñnza de la Ciencias Sociales. In: PIZZINATO, L. A. R.; PALACIOS MENA, N..; SOUTO GONZÁLEZ, X. M. (Ed.) La construcción global de una enseñanza de los problemas sociales desde el Geoforo Iberoamericano. Barcelona: Geocrítica, Textos Electrónicos, 2019. p. 291-301.

PEREIRA, S. I. M. Problemas urbanos: contributos da Geografia escolar para o desenvolvimento de aprendizagens significativas. 2017. 143 f. Dissertação (Mestrado em Ensino de História e Geografia no 3. ${ }^{\circ}$ Ciclo do Ensino Básico e Ensino Secundário) Universidade de Lisboa, Lisboa, 2017.

PINEDA-ALFONSO, J. A. La enseñanza de la participación, vijos y nuevos paradigmas. In: BORGHI, B.; GARCÍA PÉREZ, F. F.; MORENO FERNÁNDEZ, O. (Org.). Noví Cíves: cittadini dall ínfanzia ín poí. Bologna: Pàtron Editore, 2015. p. 53-62.

PIRES, L. M. Os jovens em busca do direito à cidade: os espaços públicos em questão. In: PAULA, F. M. A.; CAVALCANTI, L. S.; PIRES, L. M. (Org.). Os Jovens e suas espacialidades. Goiânia: Espaço Acadêmico, 2016. p. 93-118.

PONTUSCHKA, N. N. O conceito de estudo do meio transforma-se... em tempos diferentes, em escolas diferentes, com professores diferentes. In: VESENTINI, J. W. (Org.). O ensino de geografia no século XXI. Campinas/SP: Papirus, 2004. p. 249-288. 
PONTUSCHKA, N. N.; OLIVEIRA, A. U. (Org.). Geografia em perspectiva: ensino e pesquisa. São Paulo: Editora Contexto, 2013.

PONTUSCHKA, N. N.; PAGANELLI, I. T.; CACETE, N. H. (Org.). Para ensinar e aprender Geografia. São Paulo: Cortez, 2009.

PORTELA, M. O. B.; ALENCAR, J. J. O estudo dos espaços públicos: propostas para o ensino de Geografia e cidadania. In: CLAUDINO, S.; SOUTO GONZÁLEZ, M. X.;

DOMENECH, M. A.; BAZOLLI, J.; LENILDE, R.; GENGNAGEL, C. L.; MENDES, A.; SILVA, B. A. T. (Org.). Geografia, Educação e Cidadania. Lisboa: ZOE/Centro de Estudos Geográficos, Instituto de Geografia e Ordenamento do Território IGOT, 2019. p. 636-648.

PRESTES, Z. O rigor metodológico em pesquisa bibliográfica. Ensino Em Re-vista, Uberlândia, v. 19, n. 2, jul./dez. 2012. Disponível em:

http://www.seer.ufu.br/index.php/emrevista/article/view/14947/8447. Acesso em: 19 abr. 2019.

QUEIROZ, R. J. G. Educação geográfica e a relação sociedade-natureza. Terra Livre, v. 2, n. 53, p. 15-52, jul./dez. 2019. Disponível em:

https://www.agb.org.br/publicacoes/index.php/terralivre/article/download/1694/1527. Acesso em: 01 abr. 2020.

RECLUS, E. L. Homme et la Terre (éducation). Paris: Librairie Universelle, 1905.

RIGAMONTE, R. Projeto Nós Propomos! Metodologia ativa em ação. In: Encontro Nacional de Práticas de Ensino de Geografia: Políticas, Linguagens e trajetórias. 14., 2019. Anais... Campinas: Unicamp, 2019. p. 2861-2871. Disponível em:

https://ocs.ige.unicamp.br/ojs/anais14enpeg/article/view/3119. Acesso em: 20 dez. 2019

ROMANELLI, G. A entrevista antropológica: troca e alteridade. In: ROMANELLI, G.; BISOLI-ALVES, Z. M. M. Diálogos metodológicos sobre a prática da pesquisa. Ribeirão Preto: Legis Summa, 1998. p. 119-133.

ROZIN, E. M. Nós Propomos! Pato Branco com o ensino de Geografia do Lugar. 2019. 143 f. Dissertação (Mestrado em Educação) - Universidade Estadual do Oeste do Paraná (UNIOESTE), Francisco Beltrão, 2019.

SANSOLO, D. G. O trabalho de campo e o ensino de Geografia. Revista GEOUSP, n. 7, v. 4, p. 135-145, 2000. Disponível em: http://www.revistas.usp.br/geousp/article/view/ 123409/119728. Acesso em: 10 mar. 2019.

SANTIAGO RIVERA, J. A. S.; CLAUDINO, S. La Participación ciudadana como tema del debate en el Geoforo. In: PIZZINATO, L. A. R.; PALACOS MENA, N..; SOUTO GONZÁLEZ, X. M. (Ed.) La construcción global de una enseñanza de los problemas sociales desde el Geoforo Iberoamericano. Barcelona: Geocrítica, Textos Electrónicos, 2019. p. 276-290.

SANTOS, M. A natureza do Espaço: Técnica e tempo, razão e emoção. São Paulo: Edusp, 2017.

SANTOS, M. O espaço do cidadão. 7. ed. São Paulo: EDUSP, 2004. 
SANTOS, M. Técnica, espaço, tempo: globalização e meio técnico-científico internacional. São Paulo: Hucitec, 1994.

SÃO PAULO. Secretaria Municipal de Educação. Estudo do meio e outras saídas para o ensino noturno: construindo a educação do jovem e adulto trabalhador. Cadernos de formação, n. 3, 1992.

SÃO PAULO. Secretaria Municipal de Educação. Tema gerador e a constituição do programa: por uma nova relação entre currículo e realidade. São Paulo: SME, 1991.

SERPA, A. O trabalho de campo: uma abordagem teórica- metodológica. Boletim Paulista de Geografia, São Paulo, n. 84, p. 7-24, jul. 2006. Disponível em: http://www.uel.br/cce/geo/ didatico/omar/pesquisa_geografia_fisica/BPG84_Pesquisa.pdf. Acesso em: 20 ago. 2018.

SEVERINO, A. J. Ética e pesquisa: autonomia e heteronomia na prática científica. Cadernos de Pesquisa, v. 45, n. 158, p. 776-792, 2015.Disponível em: http://www.scielo.br/scielo.php? pid=S010015742015000400776\&script=sci_abstract\&tlng=pt Acesso em: 21 ago. 2018.

SILVA, M. M. Extensão: a face social da universidade? Campo Grande: UFMS, 2000.

SIMÕES, G. L.; SIMÕES, J. M. Reflexões sobre o conceito de participação social e contexto brasileiro. In: Jornada internacional de políticas Públicas, 7., 2015. Anais... Maranhão:

UFMA, 2015. p. 1-13. Disponível em: http://www.joinpp.ufma.br/jornadas/joinpp2015/anaisjoinpp-2015.html. Acesso: 05 out. 2019.

SOUSA, V. L. C. A.; LEITE, C. M. C. (Org.). Ensinar e aprender Geografia por meio do Projeto Nós Propomos. Brasília/DF: GEAF, 2018.

SOUTO GONZÁLEZ, X. M. Didáctica de la Geografía: problemas sociales y conocimiento del medio. Barcelona: Ediciones del Serbal, 1998.

SOUTO GONZÁLEZ, X. M.; ARAYA PALACIOS, N. M.; RODRÍGUEZ PIZZINATO, L. A. Un congreso para imitar. Ciando el compromiso y la coherencia convergem. Biblio3W -

Revista Bibliográfica de Geografía y Ciencias Sociales, Barcelona, v. XXIV, n. 1.279, p. 125, out. 2019. Disponível em:

https://revistes.ub.edu/index.php/b3w/article/view/28493/30084. Acesso em: 12 nov. 2019.

SOUTO GONZÁLEZ, X. M.; CLAUDINO, S. Construímos uma educação geográfíca para a cidadania participativa. O caso do "Projeto Nós Propomos! cidadania e inovação na educação geográfica”. Signos Geográficos, Goiânia-GO, v. 1, p. 1-16, 2019. Disponível em: https://www.revistas.ufg.br/signos/article/view/59171. Acesso em: 10 dez. 2019.

SOUTO GONZÁLEZ, X. M.; CLAUDINO, S. Educação Geográfica e Cidadania no Século XXI. In: CONGRESSO DA GEOGRAFIA PORTUGUESA PORTUGAL: TERRITÓRIO E PROTAGONISTAS. 5., 2004. Anais... Guimarães, Universidade do Minho e Associação Portuguesa de Geógrafos, out. 2004. p. 1- 14. Disponível em: http://www.apgeo.pt/files/docs/ CD_V_Congresso_APG/web/_pdf/A1_14Out_Xos\%E9\%20Souto\%20e\%20S\%E9rgio.pdf. Acesso em: 26 set. 2019.

SPOSITO, M. P. Uma perspectiva não escolar no estudo sociológico da escola. Revista USP, n. 57, p. 210-226, mar./maio 2003. Disponível em:

http://www.revistas.usp.br/revusp/article/view/33843. Acesso em: 10 jul. 2019. 
SUESS, R. C. Do Centro de Ensino Médio Ave Branca para o Distrito Federal: identificando problemas e propondo soluções - a experiência de uma educação científica por meio do projeto Nós Propomos! Revista Brasileira de Educação em Geografia, Campinas, v. 9, n. 18, p. 245-268, jul./dez., 2019. Disponível em:

https://www.revistaedugeo.com.br/ojs/index.php/revistaedugeo/article/view/632.Acesso em: 20 dez. 2019.

SZYMANSKI, H. Entrevista reflexiva: um olhar psicológico sobre a entrevista em pesquisa. In: SZYMANSKI, H. (Org.). entrevista na pesquisa em educação: a prática reflexiva. Campinas: Autores Associados, 2018.

TAZINASSO, A, C; N, M, FRANCISCHETT. Nós Propomos! Ensino e pesquisa em Geografia no contexto da formação cidadã. In. XIII ENANPEGE: A Geografia brasileira na Ciência mundo: produção, circulação e apropriação do conhecimento. 2019. Anais... São Paulo: USP, 2019. p. 1-10. Disponível em:

https://www.enanpege2019.anpege.ggf.br/resources/anais/8/1562620206_ARQUIVO_anatazi nasso-artigoenanpege.pdf. Acesso em: 15 abr. 2020.

TEIXEIRA, L. E. S. A Extensão Universitária como estímulo à Gestão Social: a experiência do "Nós Propomos". 2020. 140 f. Dissertação (Mestrado em Desenvolvimento Regional) - Universidade Federal do Tocantins, Palmas, 2020.

UNESCO: PROGRAMMES ET MÉTHODES D'ENSEIGNEMENT. I'enseignement de la géographie. França: UNESCO/PAIM, 1966. Disponível em: https://unesdoc.unesco.org/ark:/ 48223/pf0000133922. Acesso em: 06 jun. 2020.

VEIGA, I, P, A. A prática pedagógica do professor de Didática. 2. Ed. Campinas, Papirus, 1992.

VESENTINI, W. J. (Org.). O ensino de Geografia no século XXI. São Paulo: Papirus, 2004.

VLACH, V. Papel do ensino de Geografia na compreensão de problemas do mundo atual. Scripta Nova: Revista Electrónica de Geografía y Ciencias Sociales, Barcelona, v. XI, n. 245, ago. 2007. Disponível em: http://www.ub.edu/geocrit/sn/sn-24563.htm. Acesso em: 05 mar. 2020.

YIN, R. K. Estudo de caso: planejamento e métodos. Porto Alegre: Bookman. 2001.

YOUNG, M. Para que servem as escolas? Educ. Soc., Campinas, v. 28, n. 101, p. 1287-1302, set./dez. 2007. Disponível em: http://www.scielo.br/pdf/es/v28n101/a0228101.pdf. Acesso em: 20 jul. 2020.

ZAGO, N. A entrevista e seu processo de construção: reflexões com base na experiência prática de pesquisa. In: ZAGO, N.; CARVALHO, M. P.; VILELA, R. A. T (Org.).

Itinerários de pesquisa. Rio de Janeiro: DP\&A, 2003. p. 287-309.

ZANATA, A. B. Contribuições da Filosofia educacional de John Dewey para a Geografia escolar brasileira. Educativa, Goiânia, v. 16, n. 1, p. 47-64, jan./jun. 2013. Disponível em: http://seer.pucgoias.edu.br/index.php/educativa/article/view/47-64. Acesso em: 05 mar. 2020. 


\section{APÊNDICES}

\section{APÊNDICE A - Roteiro de entrevista}

Entrevistado (a):

Local:

Data:

Horário:

Duração:

1 - Descreva sua trajetória de formação inicial e continuada.

2 - Há quanto tempo trabalha no magistério?

3 - Qual a importância de realizar saídas da sala de aula para a formação dos alunos em Geografia? Você realiza nas suas práticas pedagógicas? Como? Por quê?

4 - Por que você decidiu participar do "Projeto Nós Propomos! cidadania e inovação na educação geográfica"?

5 - Como foi a implantação do projeto na sua escola? Quais desdobramentos que o projeto proporcionou até o momento?

6 - Quais recursos (humanos e materiais) que utilizou para realizar o projeto na escola?

7 - Qual ação é fundamental para a ser desenvolvida no projeto?

8 - Sob sua óptica, os alunos desenvolveram aprendizagens significativas com as saídas da sala de aula? Se sim, quais?

9 - Quais as contribuições que o projeto legou para você como professor (a)?

10 - Quais indícios de aprendizagem você pode elencar que seus alunos alcançaram com o projeto Nós propormos!?

Li e concordo com tudo que está escrito/gravado acima

Local e data: 


\title{
APÊNDICE B - Termo de Consentimento Livre e Esclarecido
}

\author{
UNIVERSIDADE DE SÃO PAULO \\ FACULDADE DE FILOSOFIA, CIÊNCIAS E LETRAS DE RIBEIRÃO PRETO \\ Departamento de Educação, Informação e Comunicação - DEDIC \\ Programa de Pós-Graduação em Educação
}

\section{TERMO DE CONSENTIMENTO LIVRE E ESCLARECIDO}

Você está sendo convidado(a) para participar da pesquisa "O Ensino de Geografia e o Estudo do local: o "Projeto Nós Propomos!" no estado de São Paulo/Brasil, sob a responsabilidade dos pesquisadores Prof. ${ }^{a}$ Dra. Andrea Coelho Lastória, docente do Departamento de Educação, Informação e Comunicação, da FFCLRP/USP; Odair Ribeiro de Carvalho Filho, $n^{\circ}$ USP: 7384461, aluno regularmente matriculada no curso de mestrado da pós-graduação em Educação desta instituição, a qual pretende-se, por meio de entrevista identificar os impactos nas ações de práticas pedagógicas de Geografia feitas pelos docentes participantes do projeto "Nós Propomos!".

Sua participação é voluntária e se dará mediante a concessão de uma entrevista que contemplará suas práticas e considerações acerca dos impactos das ações do projeto "Nós Propomos!" para a formação cidadã dos alunos no ensino de Geografia, a ser realizada em algum espaço público, fora do ambiente escolar, combinado previamente com o docente, em horário que lhe seja conveniente e fora de seu horário de serviço. A entrevista será gravada em áudio e terá duração em média entre 50 minutos a uma hora.

Informamos que se trata de uma pesquisa cuja finalidade única é coletar dados, informações, experiências e/ou práticas relativas ao "Projeto Nós Propomos! cidadania e inovação na educação geográfica" realizado por você. $\mathrm{O}$ ato de você ter desenvolvido o projeto entre os anos de 2017 a 2019 o inclui na lista de professores selecionados para a realização da entrevista.

A intenção não é classificar e/ou rotular a prática docente envolvida, mas apenas a de recolher informações que descrevam essa prática. Esclarecemos que se por ventura ocorrer algum desconforto ou risco, seja pelo assunto a ser tratado, seja pelo tempo de participação na entrevista e que você poderá interromper a entrevista e prosseguir em outro momento, ou não, de acordo com a sua vontade. Caso você não concorde em participar do presente estudo, não haverá de riscos previsíveis e/ou prejuízos a você.

Sua participação será voluntária e trará uma contribuição para o fomento à pesquisa educacional a partir do contexto em que atua, bem como para a produção de conhecimento docente cujos benefícios se configurarão numa análise à luz da literatura relativa ao tema da pesquisa, de modo a possibilitar uma ação mais condizente e adequada à realidade do ensino atual.

Além disso, o pesquisador se compromete a manter o sigilo dos dados confidenciais e/ ou dados que possam provocar constrangimentos ou prejuízos quaisquer ao voluntário desta pesquisa. Se depois de consentir em sua participação você desistir de continuar participando, tem o direito e a liberdade de retirar seu consentimento em qualquer fase da pesquisa, seja antes ou depois da coleta dos dados, independente do motivo e sem nenhum prejuízo a sua pessoa. Você não terá nenhuma despesa e, também não receberá nenhuma remuneração. $\mathrm{Na}$ 
eventual situação de alguma despesa o pesquisador arcará com os gastos, ficando você resguardado de qualquer ônus, gastos e tendo direito a devido ressarcimento caso haja.

Os resultados da pesquisa serão analisados e publicados, e seu primeiro nome será apresentado na investigação, caso você autorize. Para qualquer outra informação, você poderá entrar em contato com as pesquisadoras pelo e-mail lastoria@ffclrp.usp.br e or.cf@usp.br ou pelos fones (16) 3103-5541 e (16) 99217-0813; ou poderá entrar em contato, para eventuais dúvidas sobre questões éticas da pesquisa, com o CEP - Comitê de Ética em Pesquisa da FFCLRP-USP, Avenida Bandeirantes, 3900 - Bloco 23 - Casa 37 - 14040-901 Ribeirão Preto-SP - Brasil, fone: (16) 3315-4811/fax: (16) 3633-2660 ou ainda pelo e-mail: coetp@ffclrp.usp.br

$\mathrm{Eu}$, , R.G. aceito participar voluntariamente dessa pesquisa. Declaro que fui esclarecido do projeto de pesquisa acima descrito, autorizando que meus depoimentos integrem a pesquisa supracitada, sabendo que não terei nenhuma despesa, não vou receber nenhuma remuneração e que posso sair quando quiser. Este documento é emitido em duas vias que serão assinadas pelos pesquisadores, ficando uma via com cada um de nós.

Data: 1 Assinatura do participante

Odair Ribeiro de Carvalho Filho Prof. ${ }^{\mathrm{a}} \mathrm{Dr}^{\mathrm{a}}$. Andrea Coelho Lastória Professor e pesquisador Av. dos Bandeirantes, 3900 - Ribeirão Preto/SP (16) $99217-0813$ (16) $3315-3845$ / (16) 3315-3634 


\section{ANEXOS}

\section{ANEXO A - Ofício do Comitê de Ética em Pesquisa (FFCLRP/USP) autorizando a coleta dos dados}

Universidade de Säo Paulo

Faculdade de Filosofia, Ciếncias e Letras de Ribeirăo Preto

Comité de Ética em Pesquisa

Ot.CETPIFFCLRP-USPIOT0-dgfs.

Campus de Ribeiräo Preto

Ribeirao Preto, 21 de maio de 2019.

Prezado(a) Pesquisador(a)

Comunicamos a V. Sa. que o projeto de pesquisa intitulado "O ensino de geografia e o estudo do meio: considerações sobre o projeto 'Nós propomos!' fol analsado ad referendum do Comité de Etica em Pesquisa da FFCLRP-USP a enquadrado na categoria: APROVADO (CAAE $n^{\circ}$ $08861019.3,0000.5407)$.

Solictamos que eventuais modificaçoes ou mendas ao projeto de pesquisa sejam apresentadas ao CEP, de farma sucinta identificando a parte do projeto a ser modificada e suas justificativas. De acordo com a Resoluçẩo n'466 de 12/2/2012, devem ser entregues relatcrios semestrais e, ao término do estudo, um relatório final sempre via Plataforma Brasil.

Atenciosamente,

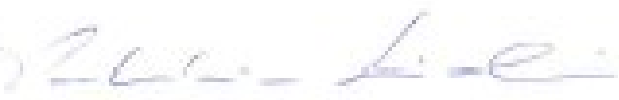

Prof." Dr." Patricia Nicolucei

Cocrdenadora

$A o(A)$ Senhor(a)

Odair Ribeiro de Carvalho Filho

Programa de Pos-graduaçáo em Educação da FFCLRP.USP

CEY - Comed de Etica ent Penquas de FFLLAP USF

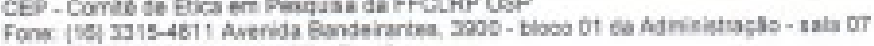

14040901 - Ake iss Prono - SP - Bris

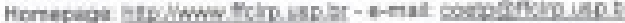




\section{ANEXO B - Parecer do Comitê de Ética em Pesquisa (FFCLRP/USP) sobre o envio do relatório parcial}

\begin{tabular}{|c|c|} 
USP - FACULDADE DE \\
FILOSOFIA, CIENCIASE \\
FIV \\
LETRAS DE RIBEIRÃO PRETO \\
DA USP - FFCLRP/USP
\end{tabular}

\section{PARECER CONSUBSTANCIADO DO CEP}

\section{DADOS DO PROJETO DE PESQUISA}

Titulo da Pesquisa: O ENSINO DE GEOGRAFIA E O ESTUDO DO MEIO: CONSIDERAÇŐES SOBRE O PROJETO "NÓS PROPOMOS!"

Pesquisador: odair ribeiro de carvalho filho

Área Temática:

Versão: 2

CAAE: 08861019.3 .0000 .5407

Instituiçăo Proponente: Faculdade de Filosofia, Ciências e Letras de Ribeirăo Preto- USP

Patrocinador Principal: Financiamento Próprio

\section{DADOS DA NOTIFICAÇÃO}

Tipo de Notificaçăo: Envio de Relatório Parcial

Detalhe:

Justificativa: Relatório parcial enviado como de solicitação da Comissão de Ética em Pesquisa.

Data do Envio: 20/09/2019

Situação da Notificação: Parecer Consubstanciado Emitido

\section{DADOS DO PARECER}

Número do Parecer: 3.691 .327

Apresentação da Notificaçăo:

Apresentaçăo de relatório parcial de pesquisa já aprovada pelo CEP-FFCLRP/USP.

Objetivo da Notificação:

Apresentação de relatório parcial de pesquisa já aprovada pelo CEP-FFCLRP/USP.

Avallaçăo dos Riscos e Beneficios:

Apresentação de relatório parcial de pesquisa já aprovada pelo CEP-FFCLRPIUSP.

Comentários e Consideraçóes sobre a Notificação:

Apresentação de relatório parcial de pesquisa já aprovada pelo CEP-FFCLRP/USP.

Consideraçбes sobre os Termos de apresentação obrigatória:

Apresentação de relatório parcial de pesquisa já aprovada pelo CEP-FFCLRPIUSP.

Endereç: Av. Bandeirantes 3.900

Bairro: Monte Alegre

UF: SP Municiplo: RIBEIRAO PRETO

Telefone: (16)3315-4811

CEP: $14.040-901$

E-mail: coetp@ffirp.usp.br 


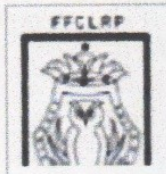

\section{USP - FACULDADE DE \\ FILOSOFIA, CIENCIAS E \\ LETRAS DE RIBEIRÃO PRETO \\ DA USP - FFCLRP/USP}

Continuaçăo do Parecer: 3.691 .327

Conclusōes ou Pendencias e Lista de Inadequaçбes:

Năo há pendências.

Consideraçóes Finais a critério do CEP:

Este parecer fol elaborado baseado nos documentos abaixo relacionados:

\begin{tabular}{|l|l|l|l|l|}
\hline Tipo Documento & Arquivo & Postagem & Autor & Situaçăo \\
\hline $\begin{array}{l}\text { Envio de Relatório } \\
\text { Parcial }\end{array}$ & relatorio_parcial.docx & $\begin{array}{c}20 / 09 / 2019 \\
15: 20: 03\end{array}$ & $\begin{array}{l}\text { odair ribeiro de } \\
\text { carvalho filho }\end{array}$ & Postado \\
\hline
\end{tabular}

\section{Situação do Parecer:}

Aprovado

Necessita Apreciação da CONEP:

Não

RIBEIRAO PRETO, 07 de Novembro de 2019

Assinado por:

Patrícia Nicolucci

(Coordenador(a)) 